\title{
An annotated list of plant viruses and viroids described in Brazil (1926-2018)
}

\author{
Elliot W. Kitajima ${ }^{1 *(1)}$ \\ ${ }^{1}$ Universidade de São Paulo, Escola Superior de Agricultura Luiz de Queiroz, Fitopatologia e Nematologia, \\ 13418-900, Piracicaba, SP, Brasil \\ *Corresponding author: Elliot W. Kitajima, e-mail: ewkitaji@usp.br
}

KITAJIMA, E.W. An annotated list of plant viruses and viroids described in Brazil (1926-2018). Biota Neotropica 20(2): e20190932. https://doi.org/10.1590/1676-0611-BN-2019-0932.

\begin{abstract}
A list of plant species, in alphabetical order by their scientific name, and the viruses found naturally infecting them in Brazilian territory, with some comments, was prepared . The production of such a list was based on a yearly catalog of publications on plant viruses collected by the author, from 1926 to 2018. Listed species of viruses were those recognized by the International Committee on Taxonomy of Viruses (ICTV), but also those characterized and still waiting official recognition, were included. Several cases of putative viral diseases were listed for historical reasons expecting to raise interest for their clarification. This list includes 345 plants species belonging to 74 families naturally infected by plant viruses in Brazil. Fabaceae and Asteraceae had most virusinfected species, respectively 49 and 36. Until 2018, a total of 213 plant virus and 6 viroid species belonging to 57 genera and 22 families and 6 orders, officially recognized by ICTV, were found naturally infecting these plants. Begomovirus and Potyvirus genera have most representatives, with 45 and 42 species, respectively. There are 59 characterized plant viruses, up to species level, described in Brazil waiting for the inclusion in the ICTV Master Species List. One hundred and thirteen viruses were identified up to genus level but still uncharacterized, while four putative isometric viruses and eleven presumptive viral diseases ("unidentified") are included in the list. A reverse catalog, listing viruses and the plant species in which they were found is also included.
\end{abstract}

Keywords: ICTV, plant species, virus species.

\section{Lista comentada de vírus e viróides de planta descritos no Brasil (1926-2018)}

Resumo: Esta publicação consiste em uma listagem de espécies de plantas, em ordem alfabética de seus nomes científicos, e dos vírus que foram encontrados naturalmente infetando-as em território brasileiro, com alguns comentários. O preparo de tal lista foi basedo nas publicações sobre vírus de plantas e as doenças que eles causam, colecionadas pelo autor de 1926 a 2018. Os vírus listados incluem aqueles já oficialmente reconhecidos pelo International Committee on Taxonomy of Viruses (ICTV), constantes do "Master Species List 2018". Também estão incluídos vírus já caracterizados, aguardando oficialização pelo ICTV, e outros casos de possíveis viroses, cujo agente causal ainda não se acha adequadamente caracterizado. A listagem inclui 345 espécies de plantas, pertencentes a 74 famílias, que foram encontradas naturalmente infetadas por diferentes vírus. Fabáceas e Asteráceas foram as famílias que tiveram mais espécies infetadas por vírus, respectivamente 49 e 36 . Até 2018, 213 espécies de vírus e 6 de viróides, pertencentes a 57 gêneros e 22 famílias e 6 ordens, oficialmente reconhecidas pelo ICTV, acham-se descritas no Brasil. Os gêneros Begomovirus e Potyvirus têm mais espécies representadas, com 45 e 42 respectivamente. Além das espécies identificadas e aceitas pelo ICTV, foram incluídas na lista 59 possíveis espécies que ainda aguardam oficialização, 113 vírus identificados a nível de gênero, quatro possíveis vírus isométricos e onze presumíveis viroses, de agentes etiológicos não confirmados. Foi incluída também uma lista reversa, com catalogação dos vírus e viróides descritos no Brasdil e suas respectivas plantas hospedeiras.

Palavras-chave: ICTV, espécies de plantas, espécies de vírus. 


\section{Introduction}

The concept that viruses are part of the bioma is still a controversial subject. Their chemical composition is akin of the cellular organisms. They have DNA or RNA as their genome, proteins (protective, enzymes) and lipid and glycid (in membrane bounded viruses). Being unable to replicate by themselves, viruses rely entirely on a cellular host to do so, as a molecular parasite. As far as we know, most of cellular organisms, from pro- to eucaryotes, have been found infected by one or more viruses, some of them already integrated into their genomes (Shors, 2008; Hull, 2014). Recent works, using next generation sequencing (NGS) or high-throughput sequencing (HTS) technologies (Reuter et al., 2015), discovered a huge number of viruslike sequences in several environments (Walker et al., 2019). Their proposition to incorporate them in the present official taxonomic system seems unreal as discussed by van Regenmortel (2016), who mentions that "the phenotypic and biological properties of members of new species taxa proposed on the basis of metagenomic data must be known before it becomes feasible to try to incorporate such hypothetical species in the current official system of virus classification".

Because the intimate relationship of viruses in the biology and evolution of cellular organisms, common sense and the ever-increasing evidences strongly suggest that viruses must be part of the living world. Theories about the origin of viruses are speculative but we can roughly list three main lines (Forterre, 2006; Garcia-Arenal et al., 2003; Koonin \& Dolja, 2006; Lefeuvre et al., 2019; Krupovic et al., 2019; Simmonds, 2009): (1) involution of a parasitic prokaryote, which gradually lost most of their genes, for the redundancy with those of host, keeping only those demanded for its own replication. Poxviruses and Mimiviruses are natural candidates for such possibility; (2) an aggroupment and reorganization of normal cell mRNAs containing information which led to their self-replication. The origin of most of RNA viruses would fit in this scenario; (3) a relic of the precellular, RNA world, when ribozymes permitted the self replication of RNA molecules. The existence of some viroids could be explained by this possibility. On the other hand, viruses, as molecular parasites, have been exerting important role in the evolution of living beings throughout the time. It is a well documented fact that gene swapping between organisms of the same or different species can be mediated by viruses. Recent works have shown a large variety of viruses, whose genome (integer or part) have been found integrated in the genome a large number of organisms of unrelated kingdom. Viral infection may be a key selection factor, eliminating susceptible species. Humanity has managed to tame several viruses for its own sake, to produce vaccines or use them as a genetic engineering tool to deliver specific genes, or to eliminate plagues, using them as insecticides or herbicides, as vector of expression of proteins, and also inducing hypovirulence in fungus (Shors, 2008; Hull, 2014).

Plants, as all the living beings, are susceptible to many viruses. Although there are several cases of viruses being able to infect both plants and arthropod vector, so far no virus is known to infect plants and vertebrates in the nature. Indeed, virology began with studies with a plant virus- Tobacco mosaic virus (TMV) at the end of the 19th century when it was discovered that the causal agent of a tobacco disease, referred to as mosaic, was able to keep its infectivity even after being filtered in bacteria-retaining porcelain filters. The term contagium vivum fluidum was initially attributed but later replaced by "virus" (which means poison). Soon viruses were found not only in other plants but also in practically all living beings. Also, TMV was the first virus to be purified around 1930 by centrifugation and demonstrated to be made up essentially by protein and a small amount of RNA, and also the first to be visualized by early transmission electron microscope in the late 1930s, revealing to be rodlike (Hull,
2014).

Plant viruses rarely cause dramatic and extensive damages to human activity as the pandemy of some human and animal viruses. On the contrary, their action is more subtle but inexorable and may cause consistent and constant losses in the quality and quantity of most of cultivated plants (vegetables, ornamentals, fruits, grains, industrial crops, forestry, etc.). Thus a good deal of plant pathology research is devoted to the study of plant viral diseases, especially because there are no economically available chemicals for curative treatment, as fungicides, antibiotics, nematicides, etc. efficient to control plant viruses. Usually, after identifying the causal virus, the management of the viral diseases concentrates on the use of genetically bred resistance varieties, cross-protection by mild strains, control of the vector, if any, crop techniques (rotation, time and local for cultivation). Recently, use of genetic engineering by gene transference between different organisms and even use of viral genes, have been tried to improve resistance in some crops, against viral infection. But only few of those transgenic plants are being used commercially, for they still face strong resistance by some sectors of the society (Hull, 2014; Rezende \& Kitajima, 2018).

Brazil, being one of the most important world producer of animal and plant-derived commodities, has special interest in understanding plant viral diseases to properly manage them. Presently about 100 researchers and graduate students are involved in investigations of many different plant viruses, to identify, characterize them and develop suitable management programs to reduce the hazards resulting from viral infection. The main problem is the vast extension of the country (8.5 square million kilometers) spanning from the equator to the subtropics, and presenting very diverse weather and soil conditions. The hot to milder climate favor the permanent presence of spontaneous vegetation, several of them potential host for a large number of crop affecting viruses, and worse, the continuous presence of all kind of vectors (arthropods, fungus, nematodes). Also, the lack of a rigorous and efficient quarantine system results in the continuous introduction of living part of plants and together, all sort of pests and pathogens, including viruses.

Historically, plant virology in Brazil began in two distinct centers in the years 1930's. One, at the Instituto Biológico, at São Paulo (SP), with A.A. Bittancourt and K.M. Silberschmidt, the last just arriving from Germany. The second, at the Instituto Agronomico, CampinasIAC (SP) with A.S. Costa, with training at Princeton, US. Both groups developed important and pioneer researchs on plant viruses, mostly on vegetable crops, tobacco, cotton and citrus. Silberschmidt's group was the first to demonstrate the role of whitefly as the vectors, of what is now known as begomoviruses. Costa demonstrated that a serious tomato and tobacco disease, known as "vira cabeça" was caused by Orthotospovirus. Perhaps one of the best works of Brazilian plant virology was to control the epidemy of citrus tristeza, caused by Citrus tristeza virus (CTV). This virus was introduced from Argentina, and resulted in the death of roughly 10 million orange plants in the state of São Paulo in the 1930's. The recovery of citrus industry was based on the finding that mortality was linked to the use of sour orange as rootstock. Its replacement by other CTV tolerant rootstock varieties solved the problem, and additionally the finding that infection of a citrus plant by a mild, protecting strain of CTV (premmunization, cross-protection) resulted in additional protection. Presently, together with other technical advances, these two procedures permitted an impressive growth of the citrus industry, and now more than 200 million orange trees are grown in the state of São Paulo, transforming this region in the largest world producer of industrialize orange juice. Costa's group had a significant growth, so that in the beginning of the year 1970's, twelve researchers were part of it, but economical problems affecting IAC, ended up with the migration of most of 
Costa's group members to other institutions as Universidade de São Paulo, Universidade de Campinas and Universidade de Brasília. This in part permitted the dispersion of the plant virology "know-how" to several research centers throughout the country, which also became the focus for the training of new generations of plant virologists. Universidade Federal de Viçosa (MG), Universidade Federal do Ceará, Universidade Federal Rural de Pernambuco, Universidade Federal do Rio Grande do Sul also participated in the nucleation of new centers of virology in Brazil. At the same time, Brazilian plant pathologist organized themselves in associations- Sociedade Brasileira de Fitopatologia (SBF) in 1967 and shortly later, the Grupo Paulista de Fitopatologia, presently Associação Paulista de Fitopatologia (GPF), in 1975, which promoted annual meetings. GPF started to publish the journal Summa Phytopathologica soon after foundation, while SBF produced Fitopatologia Brasileira in 1976, now (since 2014) Tropical Plant Pathology, to divulge results of phytopathological researches. Plant virology is part of actions promoted by the Brazilian Society of Virology. Also, training of many Brazilian plant virologists abroad as graduate students or posdocs was another important factor in the progress of plant virology in Brazil, bringing in new knowledge and research philosophy. Countries as US, Spain, the Netherlands, Japan, France, Italy, Germany among others, deserve to be mentioned in such a collaborative efforts. Some visiting scientists (T.J. Grant, W.C. Bennet, R.J. Best, C. Wetter, M. Nelson, D. Peters, etc.) also contributed to the advancement of the Brazilian plant virology.

Historically Brazil registered some important viral outbreaks in its crops: mosaic in sugar cane caused by Sugar cane mosaic virus (SCMV) in the early XXth century, which forced growers to replace noble cane for virus-resistant, rustic cultivars; Citrus tristeza virus (CTV) in 1940's wiping up to 10 million orange trees; constant threat of "vira-cabeça" disease caused by several species of orthotospoviruses in solanaceous crops being controlled by resistant varieties; a cocktail of viruses affecting strawberry yield until 1970', solved by the production of virus-free stocks; a disaster on bean production in the 1970-1980 caused by the whitefly-transmitted Bean golden mosaic virus (BGMV), now under control by tolerant and even genetically modified varieties, which obliged Brazil, the world largest producer, to import bean for a while; mosaic in papaya, caused by Papaya ringspot virus (PRSV), solved by the use of systematic roguing, etc. Details of the history of plant virology in Brazil have been described by Costa (1986) and Kitajima (1995).

To cope with such diseases and also to survey other viruses present mostly in cultivated plants, but also infecting spontaneous vegetation considering their potential as source of viruses for economic crops, Brazilian plant virologists actively investigated them. Continuous efforts have been made to control several of these viruses, which cause yield losses, using field practices, control of vectors (biological, chemical), breeding for resistance, etc. Reports of such works were published in specialized journals and bulletins, as well as presented in scientific meetings. A systematic collection of such publications were made, starting 1926 to 2018. Part of this listing has been published (Kitajima, 1986; 1995). Based on such a list, an annotated list of plant viruses described in Brazil was prepared, providing an alphabetical list of host plants, indicating the viruses found infecting them, with brief comments. As appendix, a reverse list is presented, enrolling the viruses and hosts in which they were found, following the most recent "Master virus list" produced by International Committee on Taxonomy of Viruses (ICTV) (ICTV, 2019)

\section{Material and Methods}

There are several lists of viruses described for some group of plants (e.g. ornamentals-Albouy \& Devergne, 2000; tropical plants- Brunt et al., 1990; Poaceae- Lapierre \& Signoret, 2004; Solanaceae- Marchoux et al., 2008; whitefly-borne viruses- Anderson \& Morales, 2005) or a country/region of the world (e.g. Argentina- Fernandez Valiela, 1995; Asia- Murayama et al., 1998). To produce this Brazilian plant virus list, a data base was produced by a continuous compilation of whatever publication (articles, reviews, divulging articles, abstracts, technical bulletin) produced by Brazilian plant virologists. This list is ordered by the year of publication, and then alphabetically by author's name. Whenever possible, printed version of these publications were collected and digitalized. The list starts in 1926 and was yearly updated, and in the present publication, ends in 2018. A first listing was published by the Brazilian Phytopathological Society covering 1926 to 1985, and a second, covering the period 1986 to 1993 (Kitajima, 1986; 1995). Since then, a yearly production list from 1986 to 2018 was prepared by the author. These publications from 1926 to 2018 served as the basis for the present work. The present listing was prepared, going through these publications and picking up those reporting cases of natural infection by viruses in any species of plant, cultivated or not, made in the Brazilian territory.

Until the 1950's plant virus identification was entirely based on symptoms and some biological properties, as stability in vitro, mode of transmission (mechanical, by vector, grafting, seed) and host range. Later, serodiagnosis and electron microscopy was introduced, giving a more precise and reliable identification of the causal viral agent. Only after the 1980's, with the use of molecular techniques, a faster and cost-efficient detection and identification procedure for plant viruses became available. Thus, for instance, what was referred to as "viruses of the infectious chlorosis of malvaceae complex" around 1930 to 1960 (Silberschmidt, 1943), is now known to incorporate a long list of begomoviruses. In the present list, early descriptions were respected as it was made originally by author(s) with the resources then available. In some cases, identification could be reassessed and corrected, if this was such a case. Today routinely plant viruses are correctly identified mostly by molecular tools as PCR or RT-PCR and in some instances, by NGS/HTS. However, in many instances the required Koch's postulate have not been completed (Hull, 2014; Rezende \& Kitajima, 2018). Also, virus identity followed, whenever possible, the classification as accepted by the International Committee on Taxonomy of Viruses (ICTV), including the periodic updating. Besides virus species officially accepted by ICTV and part of the Master List, we listed several viruses already characterized, but still waiting for official recognition. And finally, for historical reasons, and a stimulus for a reassessment, cases of possible viral diseases, with correct identification still pending, were included.

The list was prepared ordering the plant species, alphabetically by scientific name, and whenever possible, indicating the common name. In each species, viruses naturally infecting them were listed following the order presented in the ICTV list (genus and species), with a small comment on described symptoms, geographical location, economical importance, some additional information and the references. Shortened references are listed after each virus described to facilitate the search for it by the reader. To have the correct scientific names of host plants and describer's authority, information provided by the site "International Plant Name Index" were adopted. A separate list was prepared, on reverse way, by virus name, and the infected host, but without comments. Certainly, this list must have mistakes, and the author requests for the careful reader to feed-back him with the correct information, so that the error can be corrected. To access the list of publications on plant viruses mostly from Brazil, made by Brazilian plant virologists, from 1926 to 2018, please find the site http://www. $\underline{\text { lfn.esalq.usp.br/NAP. }}$ 


\section{Results and Discussion}

From 1926 to 2018,345 plants species belonging to 74 families could be listed as naturally infected by plant viruses and viroids in Brazil (see list below). Among these families, Fabaceae and Asteraceae had most virus-infected species, respectively 49 and 36 . There are a total of 213 plant virus and 6 viroid species, belonging to 57 genera, 22 families and 6 orders, officially recognized by ICTV and included in the ICTV's Master List of 2018B, found naturally infecting these plants in Brazilian territory. Begomovirus (Geminiviridae) is the genus with most representatives, with 45 described species, followed by Potyvirus (Potyviridae), with 42, Potexvirus (Alphaflexiviridae) and Carlavirus (Betaflexiviridae), with 13 and 9, respectively. On the other hand, 59 characterized plant virus (unclassified) at species level described in Brazil, are waiting for the inclusion in the Master List. One hundred and thirteen viruses, are reported most of them identified to the genus level, but still uncharacterized at species level (unidentified). Finally four putative isometric viruses, still unidentified and ten presumptive viral diseases ("unidentified") are included in the list. Tomato (Solanum lycopersicum- Solanaceae) is the species in which, by and large, more viruses have been described (37 recognized, 9 unclassified, and 4 unidentified), followed by potato (Solanum tuberosum-Solanaceae) (17 recognized and 1 unclassified) and common bean (Phaseolus vulgaris- Fabaceae) (17 recognized, and 1 unidentified). Such numbers certainly reflects the susceptibility of these cultures to viruses, some of them inducing significative losses, and the attention they received by the virologists. Also, the recent introduction of new assay methods as the next generation sequencing is rapidly increasing the detection of new viruses, although in many cases little work has been done to complete the characterization of the virus, including the fulfillment of the Koch's postulate.

A reverse list, enrolling the plant viruses and their respective host plant species, found naturally infected, is presented at the end of the text (Table 1). Cucumber mosaic virus (CMV- Cucumovirus) was the virus found infecting the largest number of different plant species (59), followed by Potato virus Y (PVY- Potyvirus) (31) and Tomato spotted wilt virus (TSWV- Orthotospovirus) (23). It should be emphasized that despite being largely disseminated, CMV causes usually only diseases of marginal importance in cultivated plants. Considering different Brazilian regions, the number of described cases decreases from Southeast, South, Center-West, Northeast and North reflecting the population of plant virologists in each region and the intensity of agricultura activities.

Because systematics is a dynamic process, it is likely that taxonomic positions of orders, families, genera and species of plant viruses may suffer alterations in the future, as well as due to more critical identification procedures, especially sequencing. We expect to incorporate such changes, besides the inclusion of new viruses to update continuously this list.

List of plant species with viruses and viroids found infecting them, described in Brazil (1926-2018).

A

*Abelmoschus esculentus Moench (okra) Malvaceae Begomovirus

Infectious chlorosis of malvaceae complex (ICMC)

Bright yellow mosaic symptoms were described in cultivated okra, with low incidence, and identified as being caused by whitefly transmitted virus of the ICMC, in S. Paulo state (1). The cv. 'Chifre de Veado, seleção Sta. Cruz 47' developed in the UFRRJ revealed to be highly resistant against begomovirus (2). Whitefly transmitted begomovirus, possibly related to ICMC was also described infecting okra in Manaus, AM (3).

Ref.: (1) Costa, A.S. Phytopathol.Zeit. 24: 97. 1955; (2) Sudo, S. et al. Fitopatologia 9: 72; 1974; (3) Kitajima, E.W. et al. Acta Amazonica 9: 633.1979

*Before the advent of the molecular tools to identify different begomoviruses, most of whitefly transmitted viruses were referred to as ICMC, which today is known to comprehend a large number of different begomovirus species identified using molecular tools. For historical reasons, these cases will be registered in this annotated list as ICMC.

Sida micrantha mosaic virus (SimMV)

SimMV was detected in the states of GO and DF, infecting okra causing mosaic symptoms (1).

Ref.: (1) Aranha, A.S. et al. Trop.Plant Pathol. 36: 14. 2011.

\section{*Abutilon striatum Dicks (Chinese lantern) Malvaceae Begomovirus \\ Abutilon mosaic Brazil virus (AbMBV)}

First description of an infectious chlorosis in Chinese lantern in Brazil was made by Silberschmit (1). The disease commonly affects this ornamental wherever the plant is cultivated causing bright yellow mosaic. The causal agent is not seed-borne but is transmissible by grafting to A. striatum and Sida spp. It may be mechanically transmitted with difficulty. This begomovirus was first to be demonstrated to be vectored by the whitefly Bemisia tabaci $(2,3)$. AbMBV, initially referred to as Infectious chlorosis virus, was found infecting several species of malvaceae, besides economically important cultures as common bean, soybean and tomato. Its genome was completely sequenced showing to be different from an isolate of West Indies, and formally named as Abutilon mosaic Brazil virus- AbMBV (4).

Ref.: (1) Silberschmidt, K. Arq.Inst.Biol. 14: 105. 1943; (2) Orlando, A. \& Silberschmidt, K. Arq.Inst.Biol. 16: 1. 1946; (3) Flores, E. \& Silberschmidt, K. Phytopath.Z. 60: 181-195.1967; (4) Paprotka, T. et al. Arch.Virol. 155: 813. 2010.

\section{*Acanthospermum hispidum DC (bristly starbur, goat's headbristly starbur, goat's head) Asteraceae \\ Curtovirus unidentified \\ Brazilian tomato curly top virus (BrCTV) \\ Bristly starbur's plant exhibiting general chlorosis, vein clearing,} witches' broom symptoms were found to be infected by a possible isolate of the Beet curly top virus (CTV), being leafhopper transmitted $(1,2)$. These infected bristly starbur's plants may serve as the reservoir for the virus which was found infecting tomato and tobacco in the state of São Paulo. This virus should be molecularly characterized to confirm the suspicion that it represents a Brazilian isolate of Beet curly top virus (BCTV).

Ref.: (1) Bennett, C.W. \& Costa, A.S. J. Agric. Res. 78: 675. 1949; (2) Costa, A.S. III Sem.Bras.Herbicidas e Ervas Daninhas p. 69. 1960

\section{*Acmella oleracea (L.) R.K.Jansen (Jambu) Asteraceae Cucumovirus \\ Cucumber mosaic virus (CMV)}

During surveys made on jambú, a native plant of the Amazon basin used as spice in local cuisine, in the state of Pará for possible viral diseases, plants exhibiting mosaic symptoms were found. The causal agent was able to be transmitted mechanically to several test plants, and molecular assays identified it as an isolate of CMV, subgroup IA (1).

isolado do CMV do subgrupo IA (1).

Ref.: (1) Quadros, A.F. et al. Res.431, 40 Cong.Paul.Fitop., 2017. 
Table 1. List of plant viruses and viroids described in Brazil, indicating the plant species in which they were found infecting naturally. Based on the Master Species List 2018 B, of the International Committee on Virus Taxonomy.

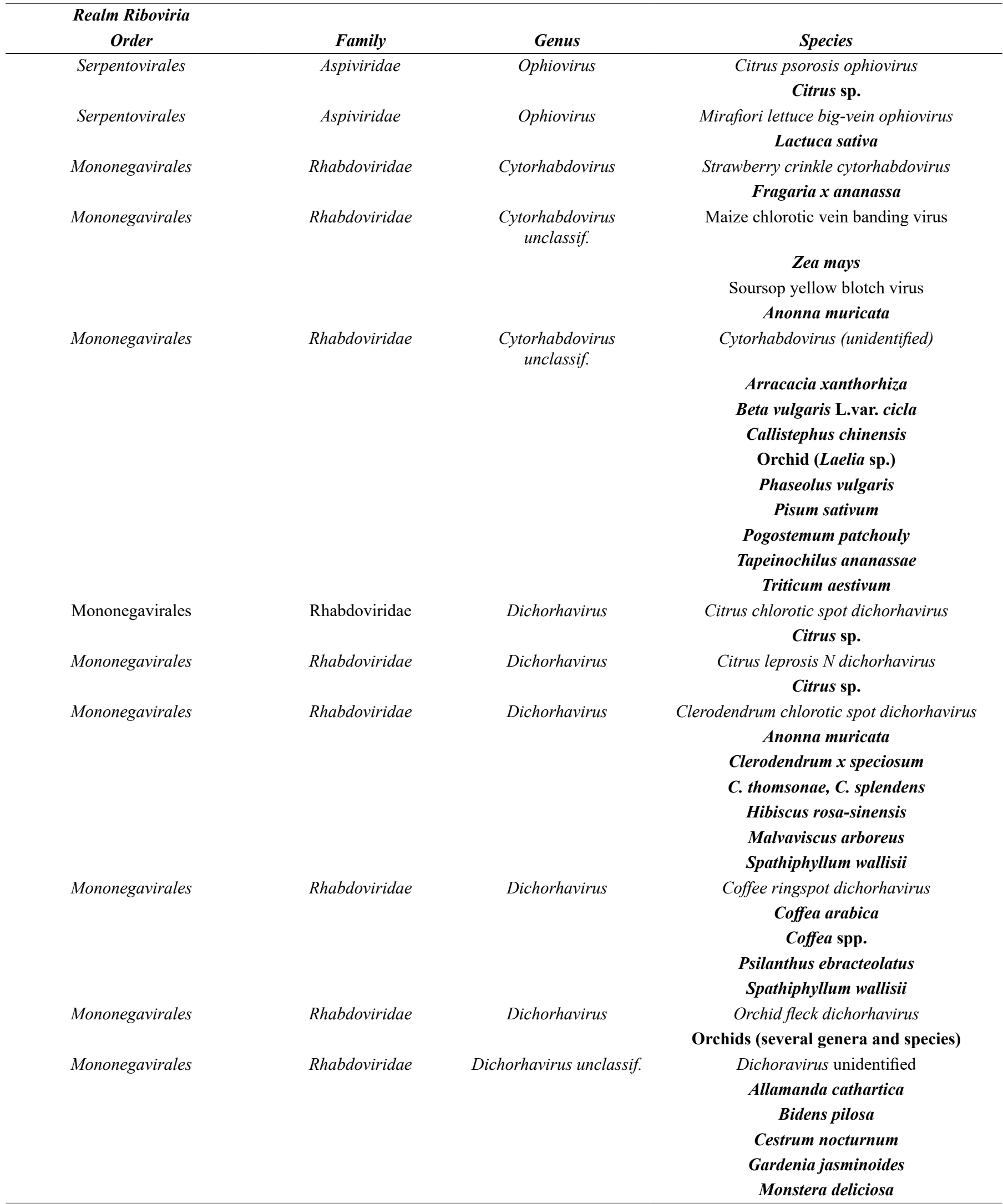


Kitajima EW

Continuation Table 1.

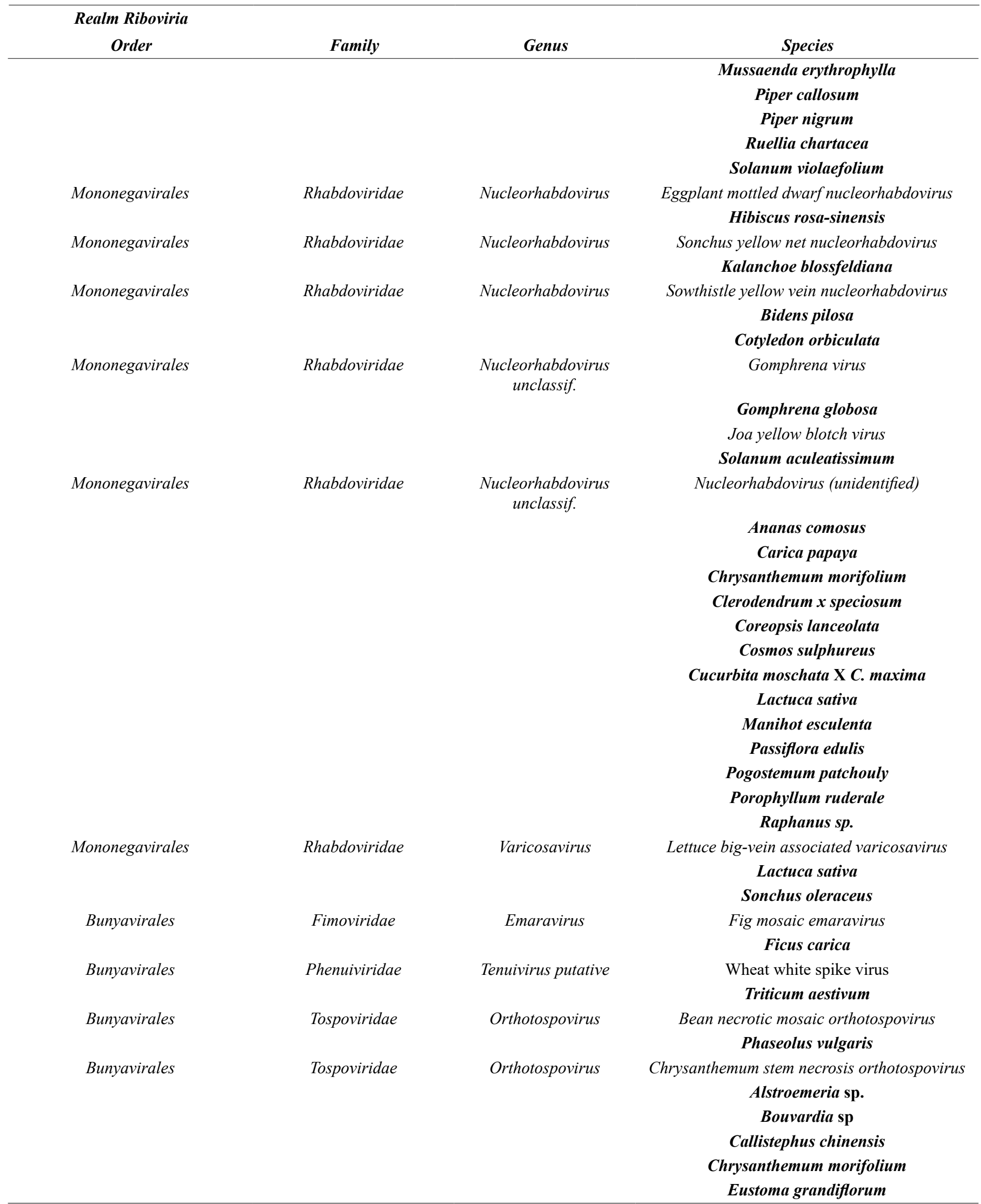


Continuation Table 1.

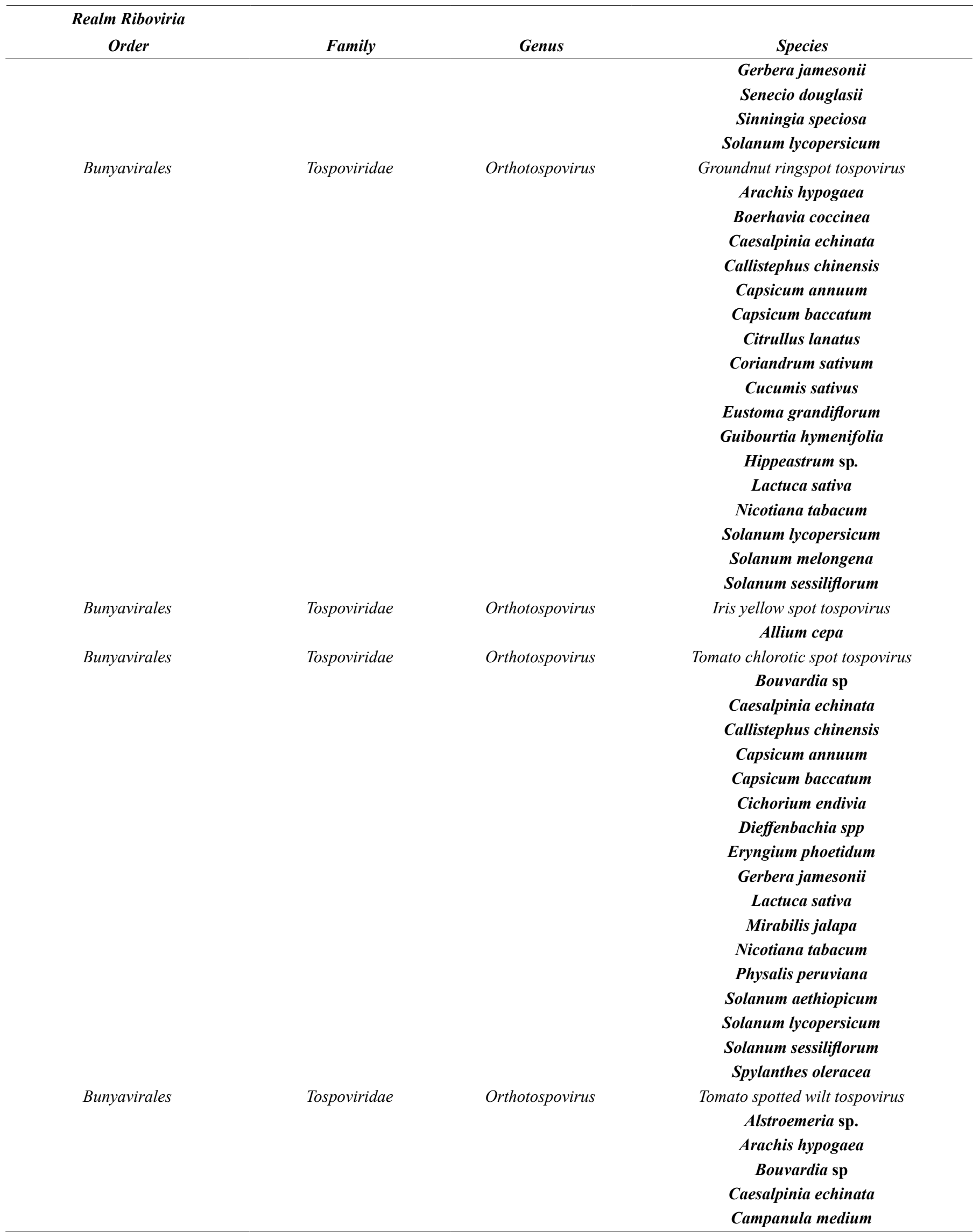


Continuation Table 1.

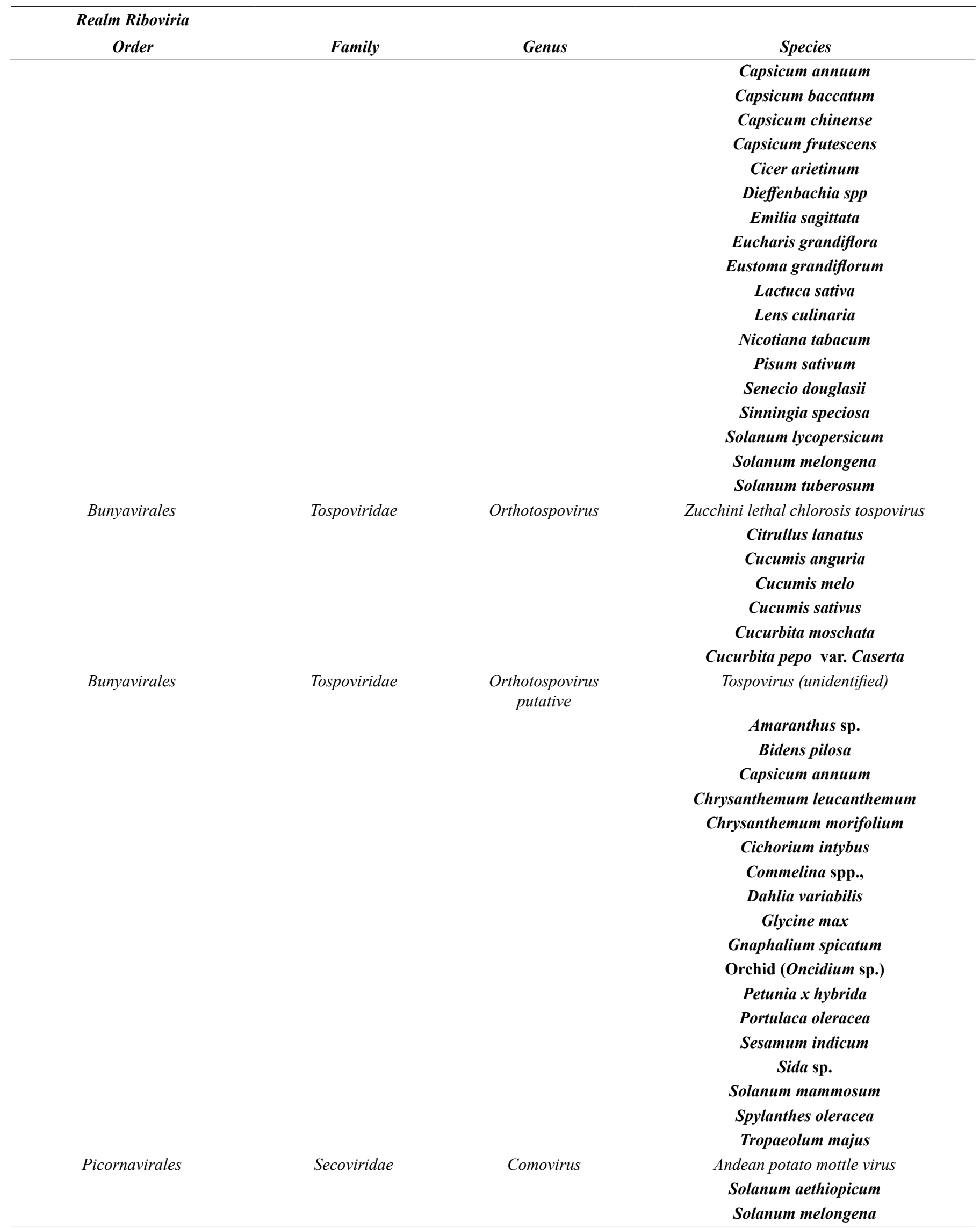


Continuation Table 1.

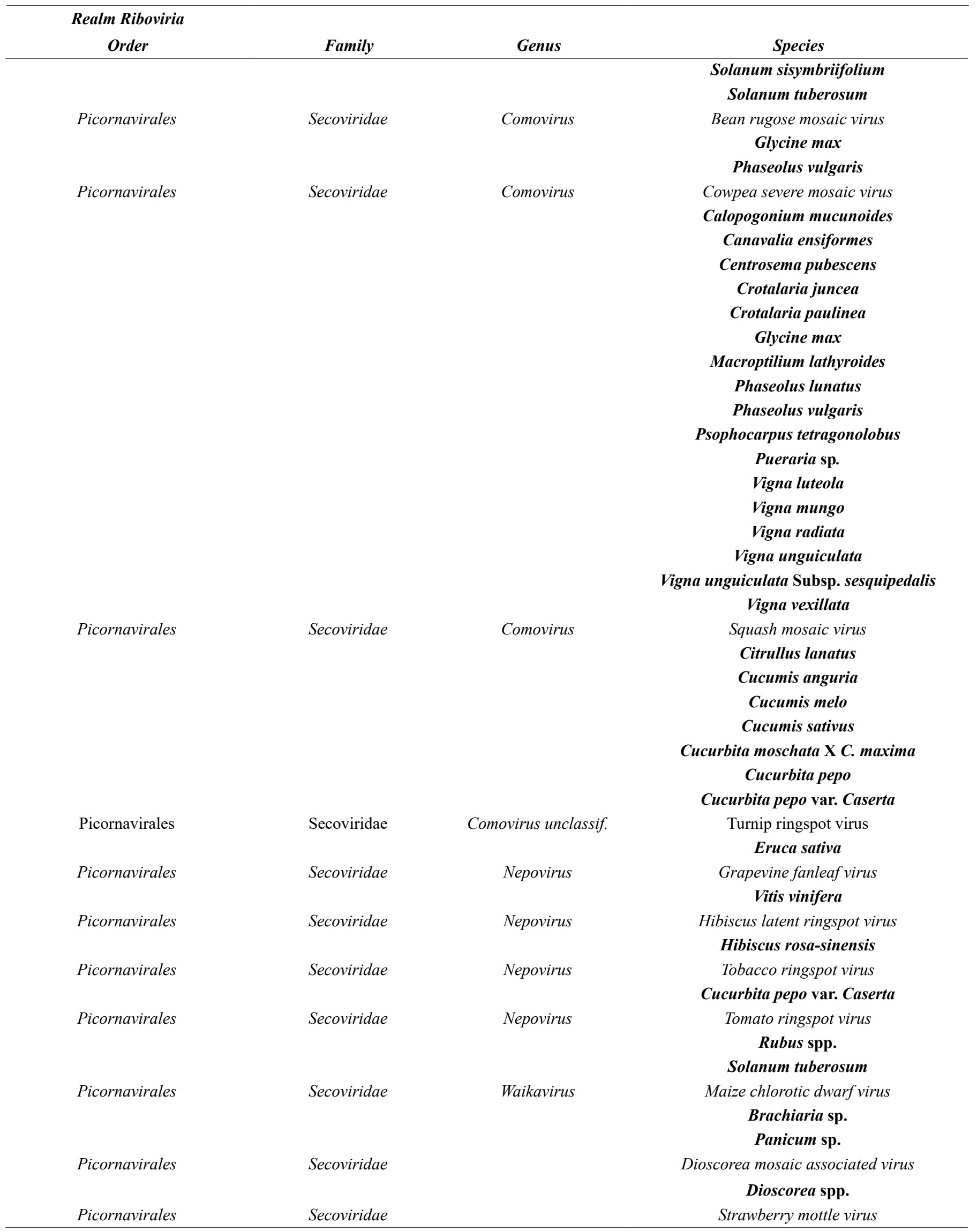


Continuation Table 1.

\begin{tabular}{|c|c|c|c|}
\hline $\begin{array}{c}\text { Realm Riboviria } \\
\text { Order }\end{array}$ & Family & Genus & Species \\
\hline \multirow{2}{*}{ Picornavirales } & & & Fragaria $x$ ananassa \\
\hline & & & Lactuca sativa \\
\hline Tymovirales & Alphaflexiviridae & Allexivirus & $\begin{array}{c}\text { Garlic mite-borne filamentous virus } \\
\text { Allium sativum }\end{array}$ \\
\hline Tymovirales & Alphaflexiviridae & Allexivirus & $\begin{array}{c}\text { Garlic virus } B \\
\text { Allium sativum }\end{array}$ \\
\hline Tymovirales & Alphaflexiviridae & Allexivirus & $\begin{array}{l}\text { Garlic virus } C \\
\text { Allium sativum }\end{array}$ \\
\hline Tymovirales & Alphaflexiviridae & Potexvirus & $\begin{array}{c}\text { Alternanthera mosaic virus } \\
\text { Angelonia } \text { sp. } \\
\text { Helichrysum sp. } \\
\text { Portulaca oleracea } \\
\text { Salvia splendens } \\
\text { Scutellaria } \text { sp. } \\
\text { Torenia } \text { sp. }\end{array}$ \\
\hline Tymovirales & Alphaflexiviridae & Potexvirus & $\begin{array}{c}\text { Bamboo mosaic virus } \\
\text { Bambusa vulgaris }\end{array}$ \\
\hline Tymovirales & Alphaflexiviridae & Potexvirus & $\begin{array}{l}\text { Hydrangea ringspot virus } \\
\text { Hydrangea macrophylla }\end{array}$ \\
\hline Tymovirales & Alphaflexiviridae & Potexvirus & $\begin{array}{c}\text { Malva mosaic virus } \\
\text { Malva parviflora }\end{array}$ \\
\hline Tymovirales & Alphaflexiviridae & Potexvirus & $\begin{array}{c}\text { Opuntia virus } X \\
\text { Several cactaceae species }\end{array}$ \\
\hline Tymovirales & Alphaflexiviridae & Potexvirus & $\begin{array}{l}\text { Potato aucuba mosaic virus } \\
\text { Solanum tuberosum }\end{array}$ \\
\hline Tymovirales & Alphaflexiviridae & Potexvirus & $\begin{array}{c}\text { Potato virus } X \\
\text { Solanum tuberosum }\end{array}$ \\
\hline Tymovirales & Alphaflexiviridae & Potexvirus & $\begin{array}{c}\text { Schlumbergera virus } X \\
\text { Several cactaceae species }\end{array}$ \\
\hline Tymovirales & Alphaflexiviridae & Potexvirus & $\begin{array}{c}\text { White clover mosaic virus } \\
\text { Trifolium } \mathbf{s p .}\end{array}$ \\
\hline Tymovirales & Alphaflexiviridae & Potexvirus & $\begin{array}{c}\text { Zygocactus virus } X \\
\text { Several cactaceae species }\end{array}$ \\
\hline Tymovirales & Alphaflexiviridae & Potexvirus unclassif. & $\begin{array}{l}\text { Caladium virus } \mathrm{X} \\
\text { Caladium bicolor }\end{array}$ \\
\hline
\end{tabular}


List of plant viruses and viroids in Brazil

Continuation Table 1.

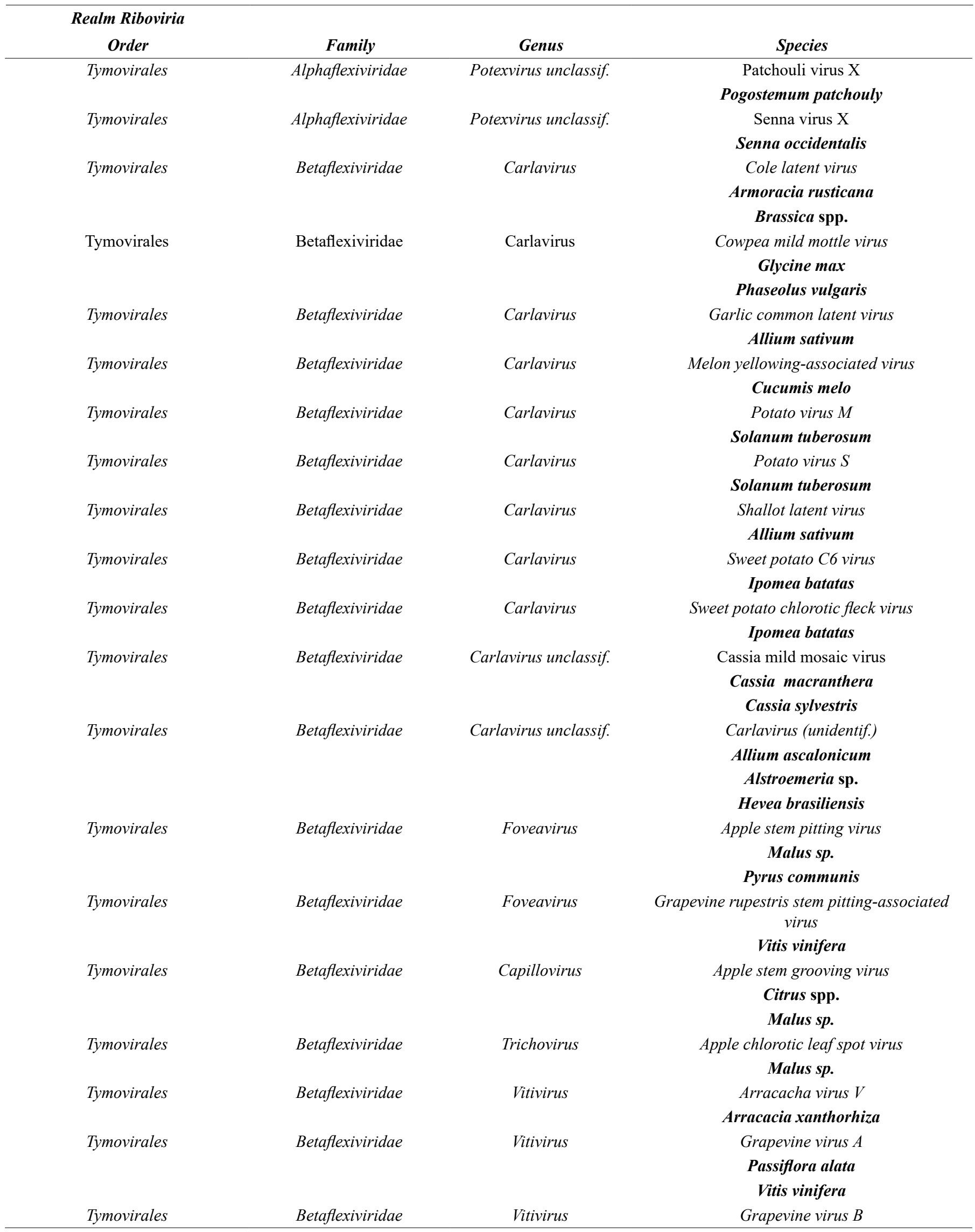


Kitajima EW

Continuation Table 1.

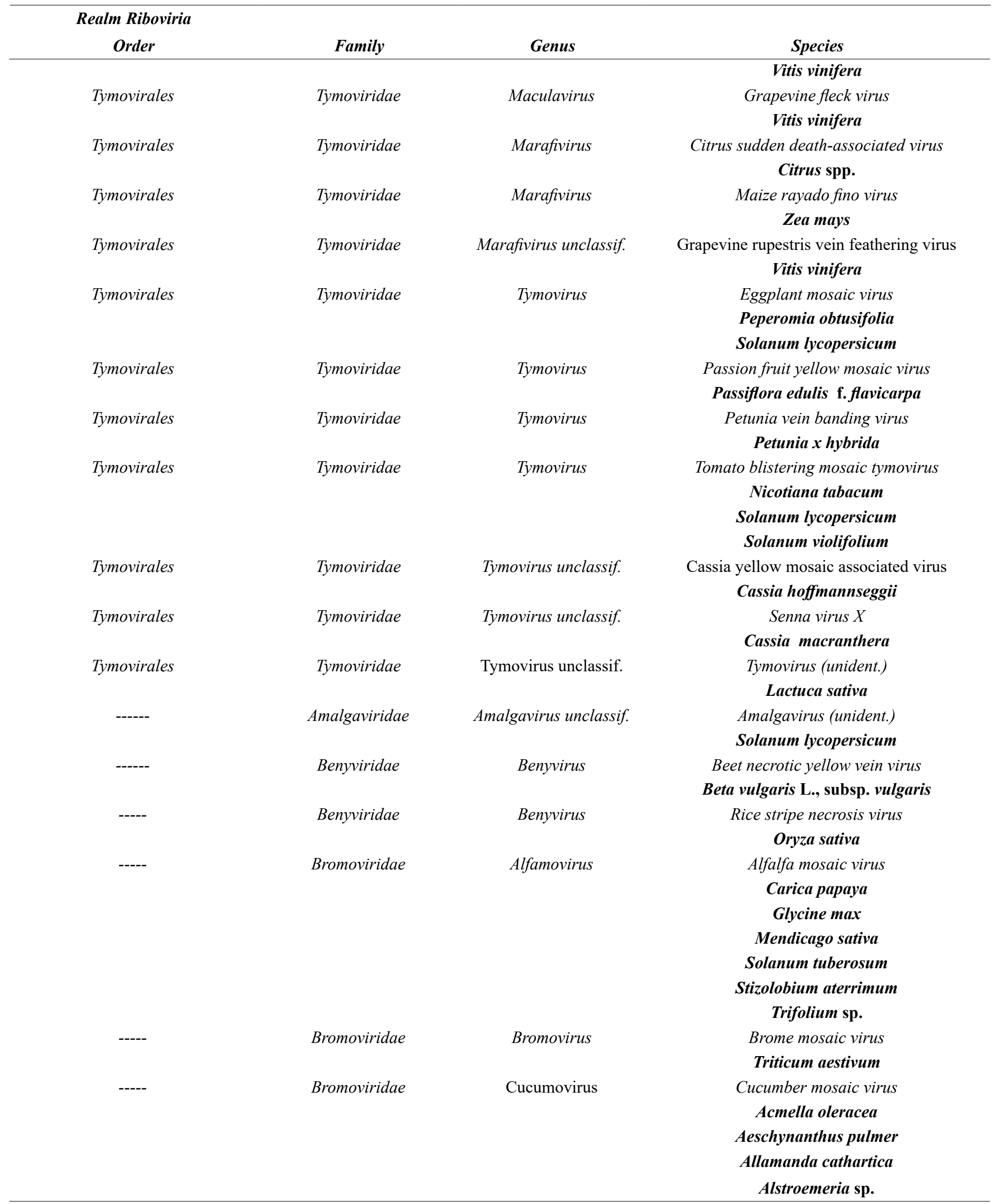


List of plant viruses and viroids in Brazil

Continuation Table 1.

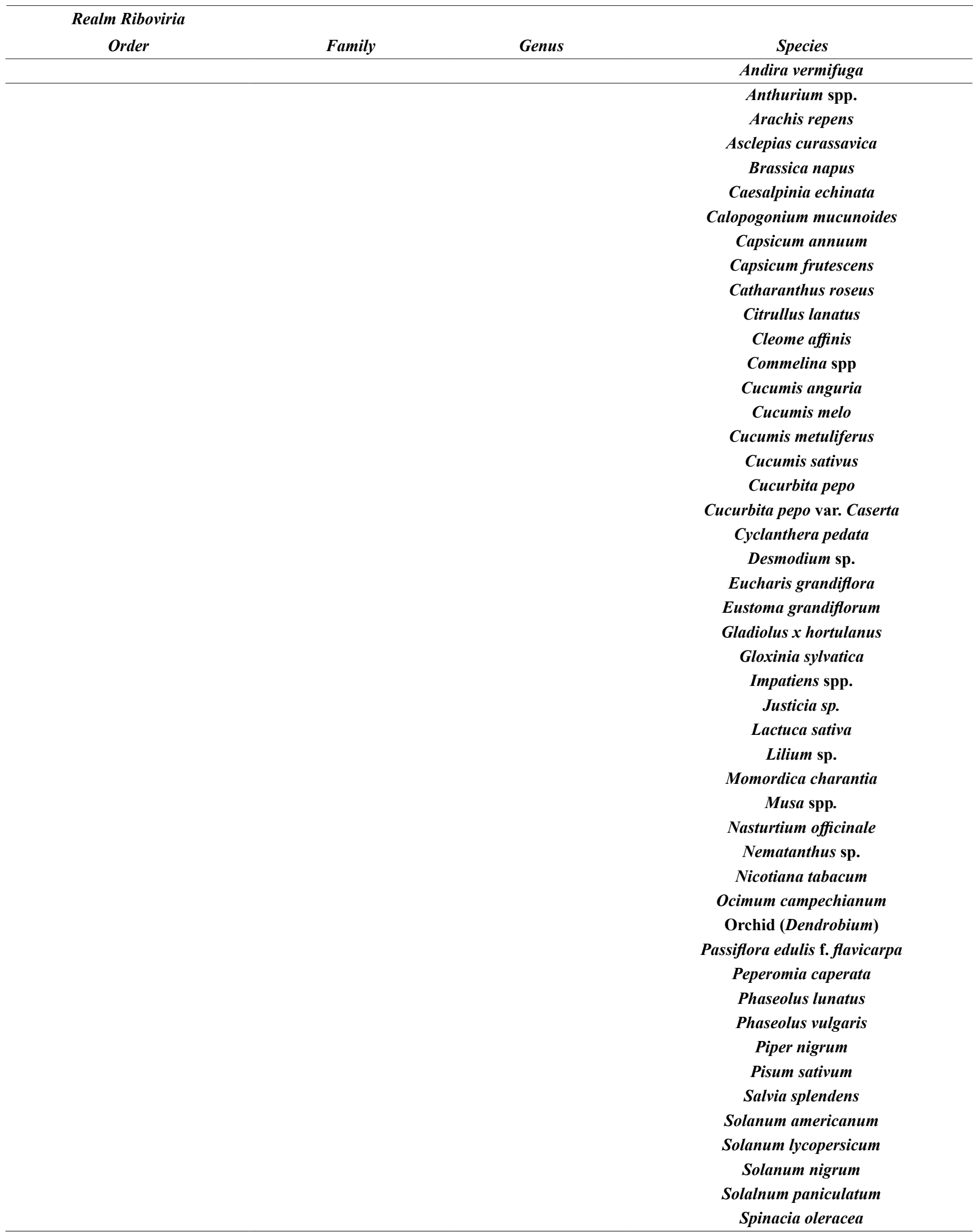


Continuation Table 1.

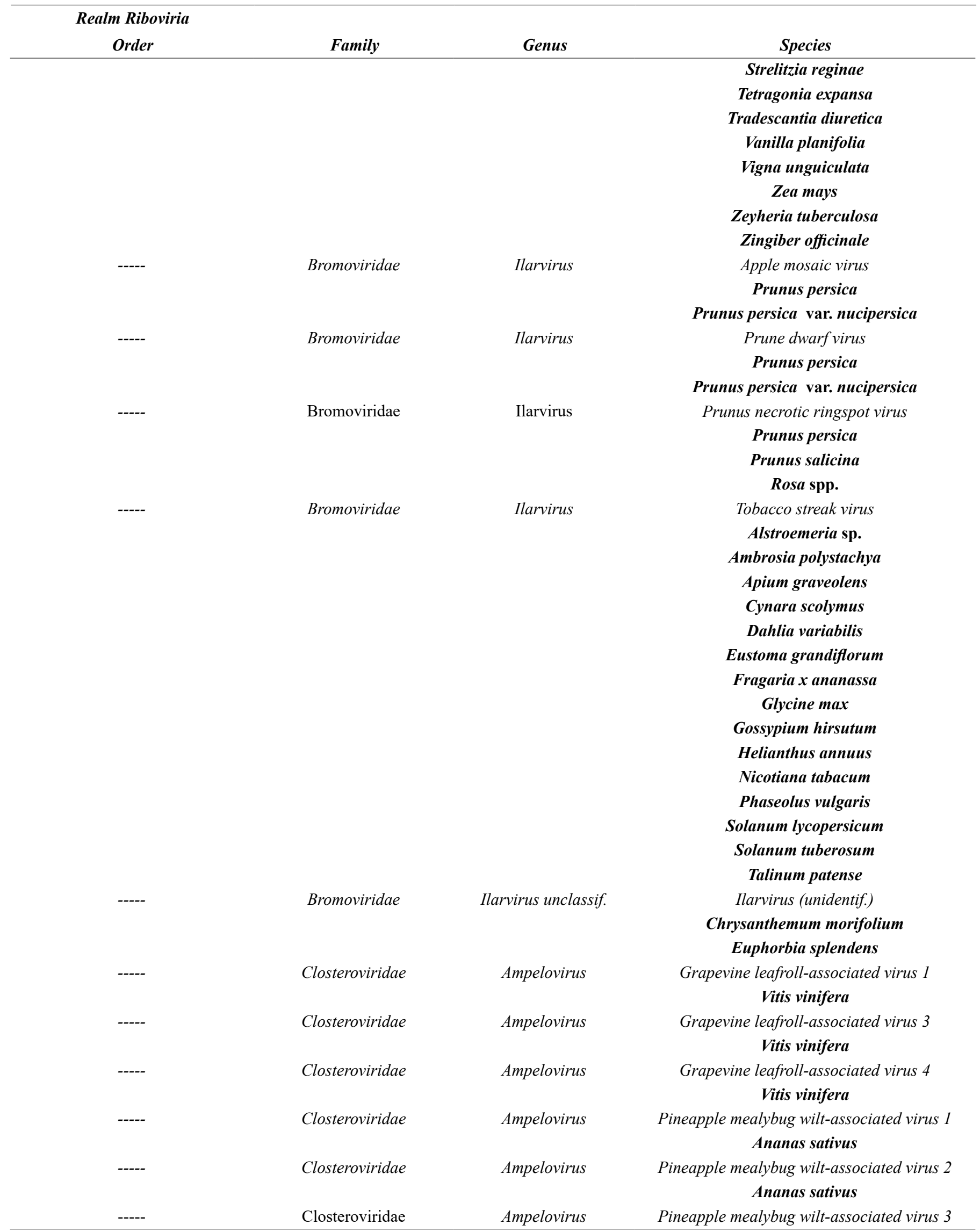


Continuation Table 1.

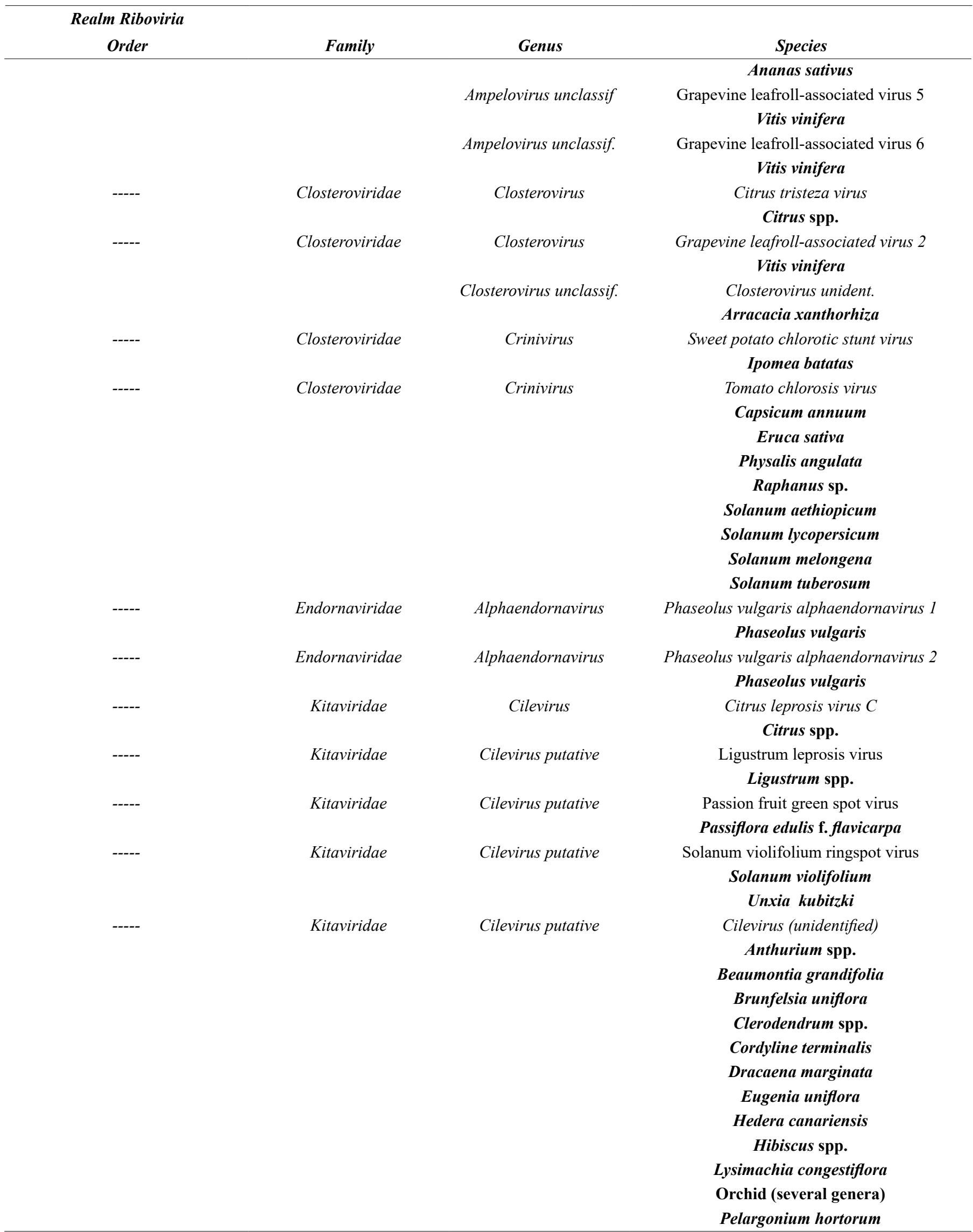


Kitajima EW

Continuation Table 1.

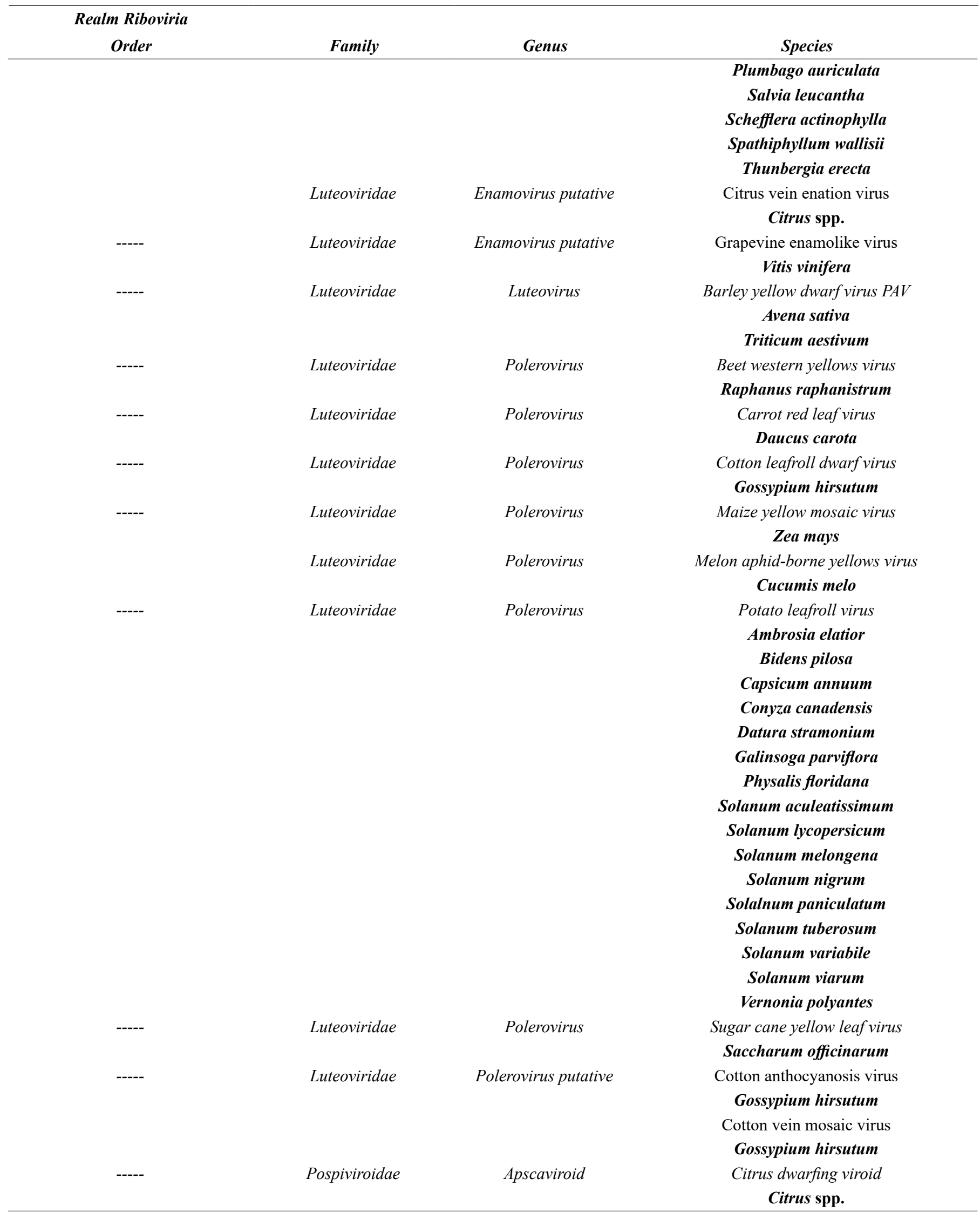


List of plant viruses and viroids in Brazil

Continuation Table 1.

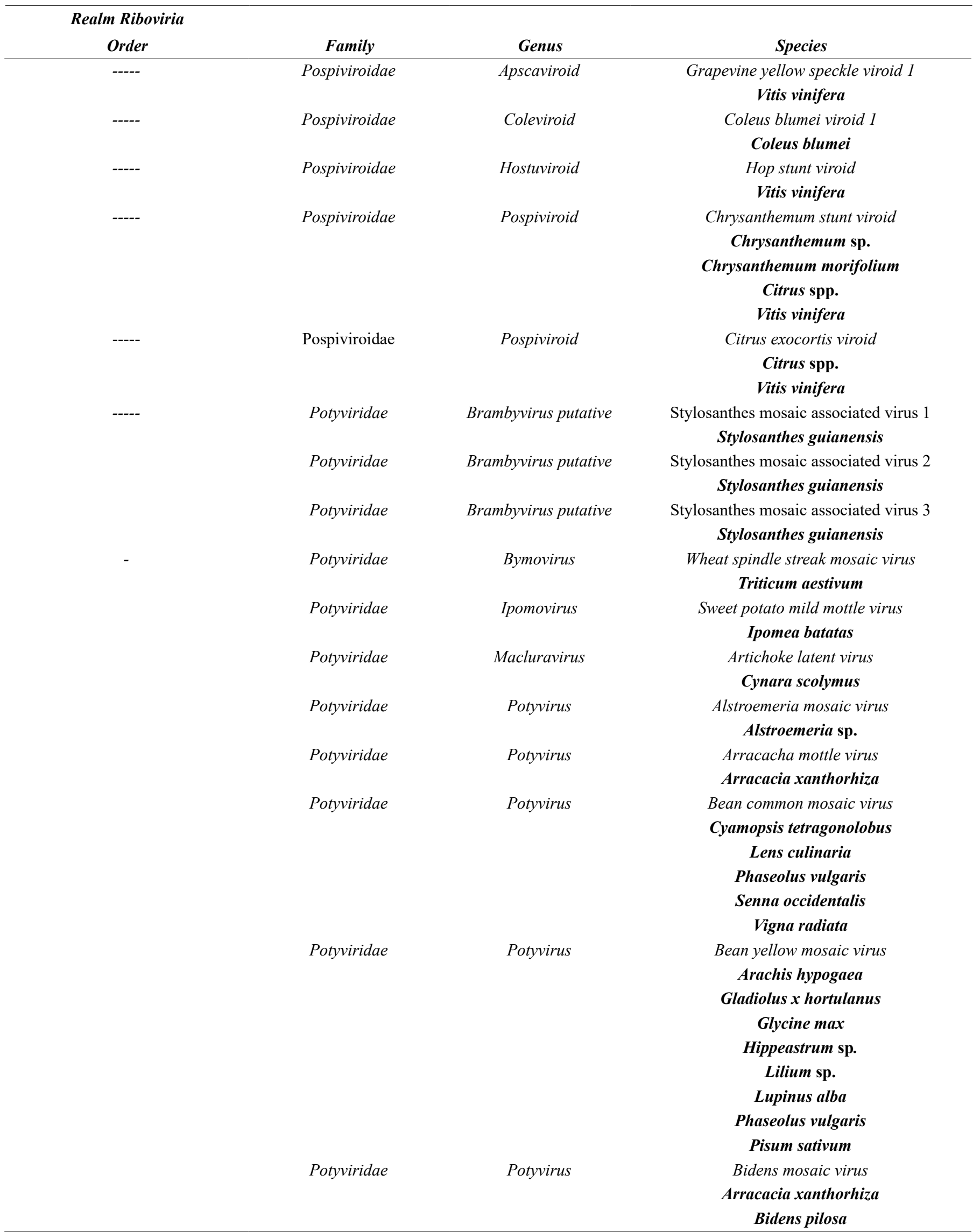


Kitajima EW

Continuation Table 1.

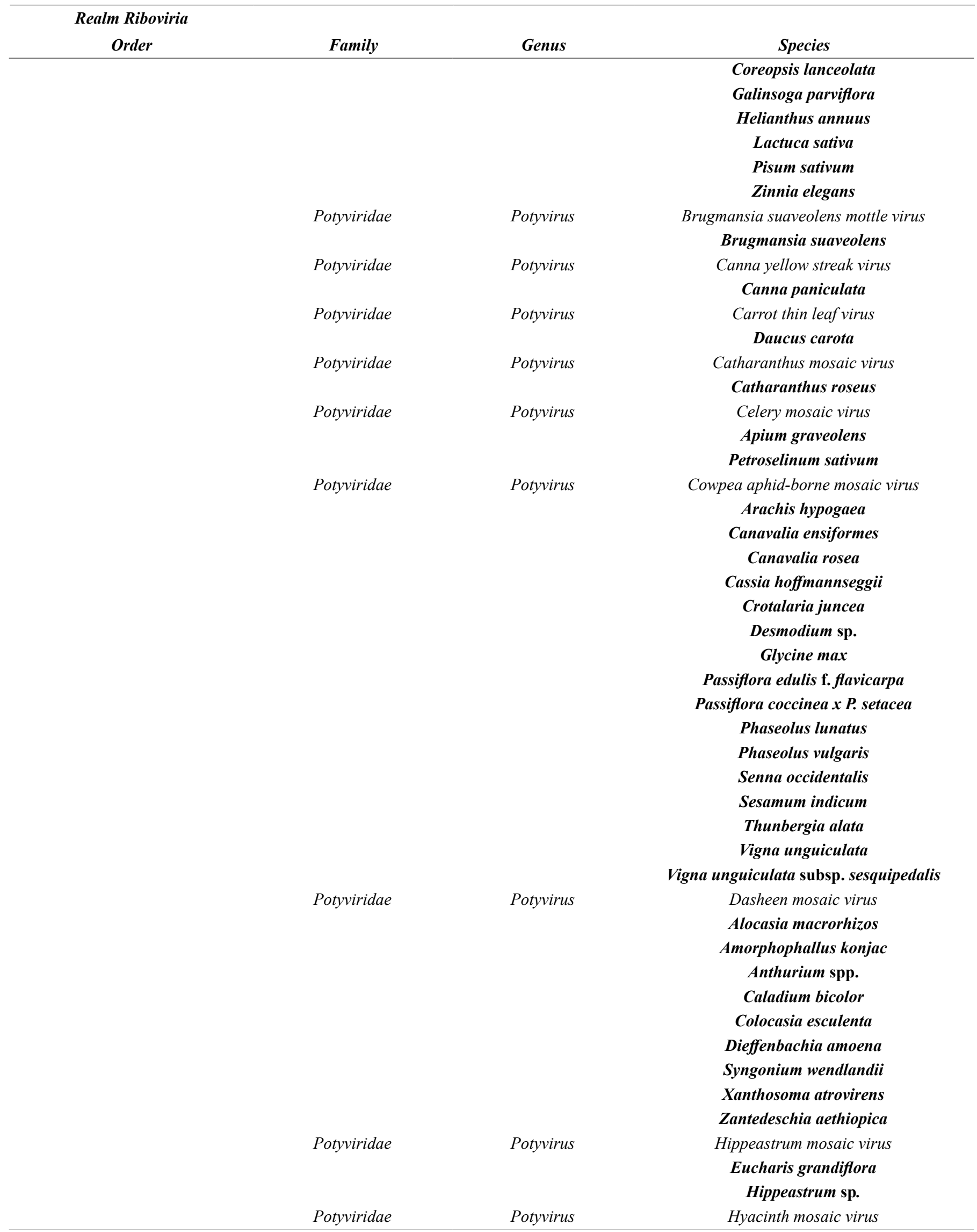


Continuation Table 1.

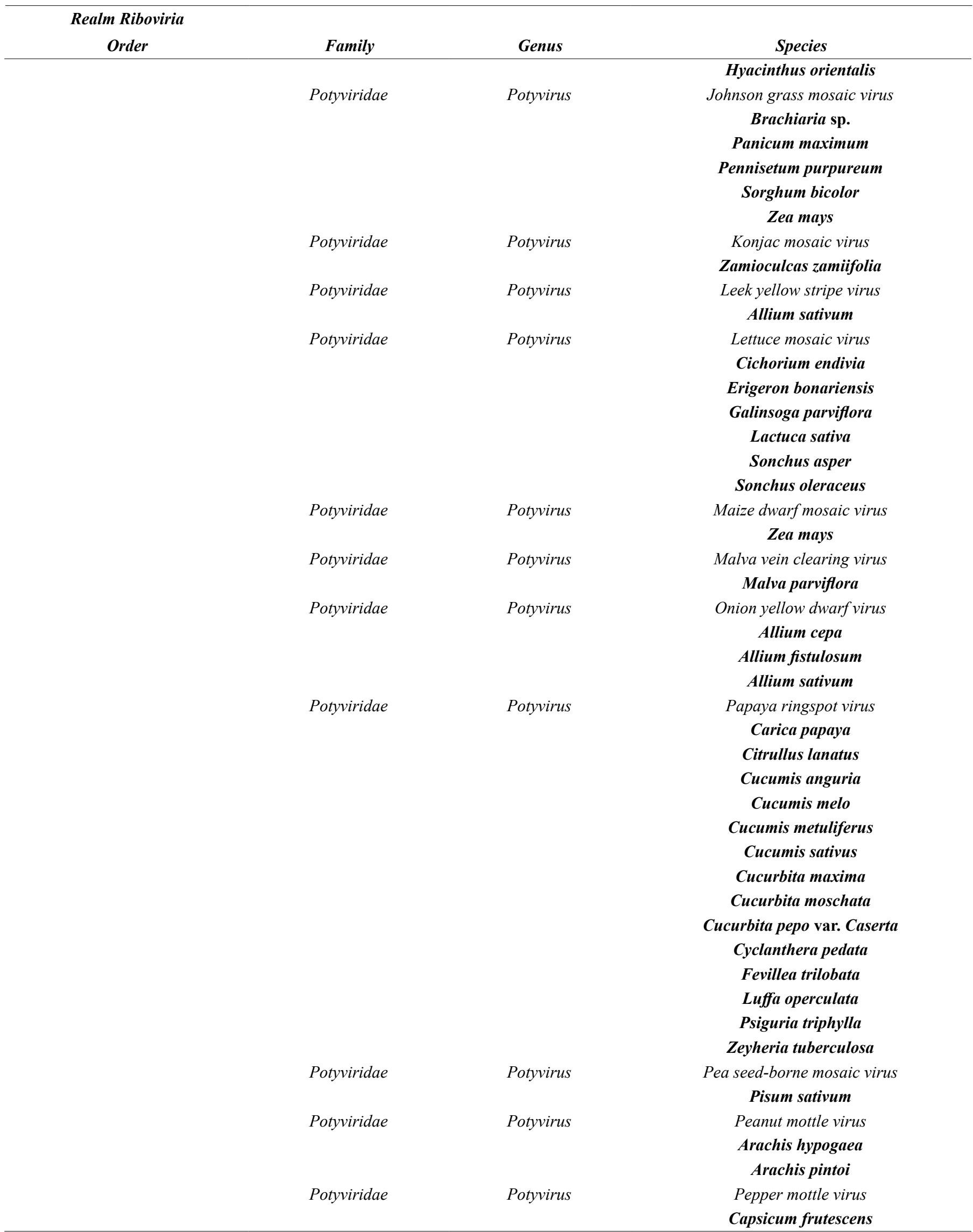


Kitajima EW

Continuation Table 1.

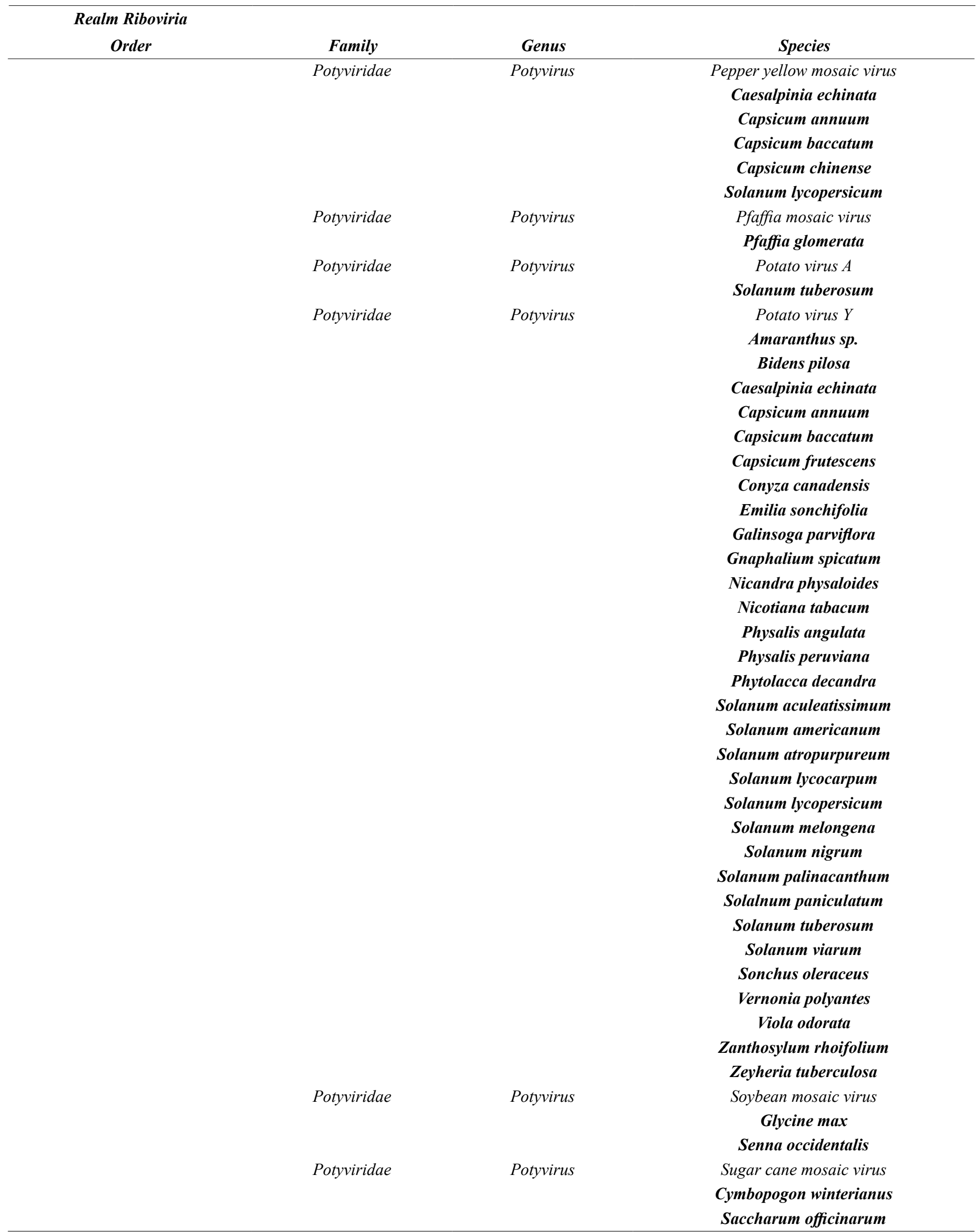


Continuation Table 1.

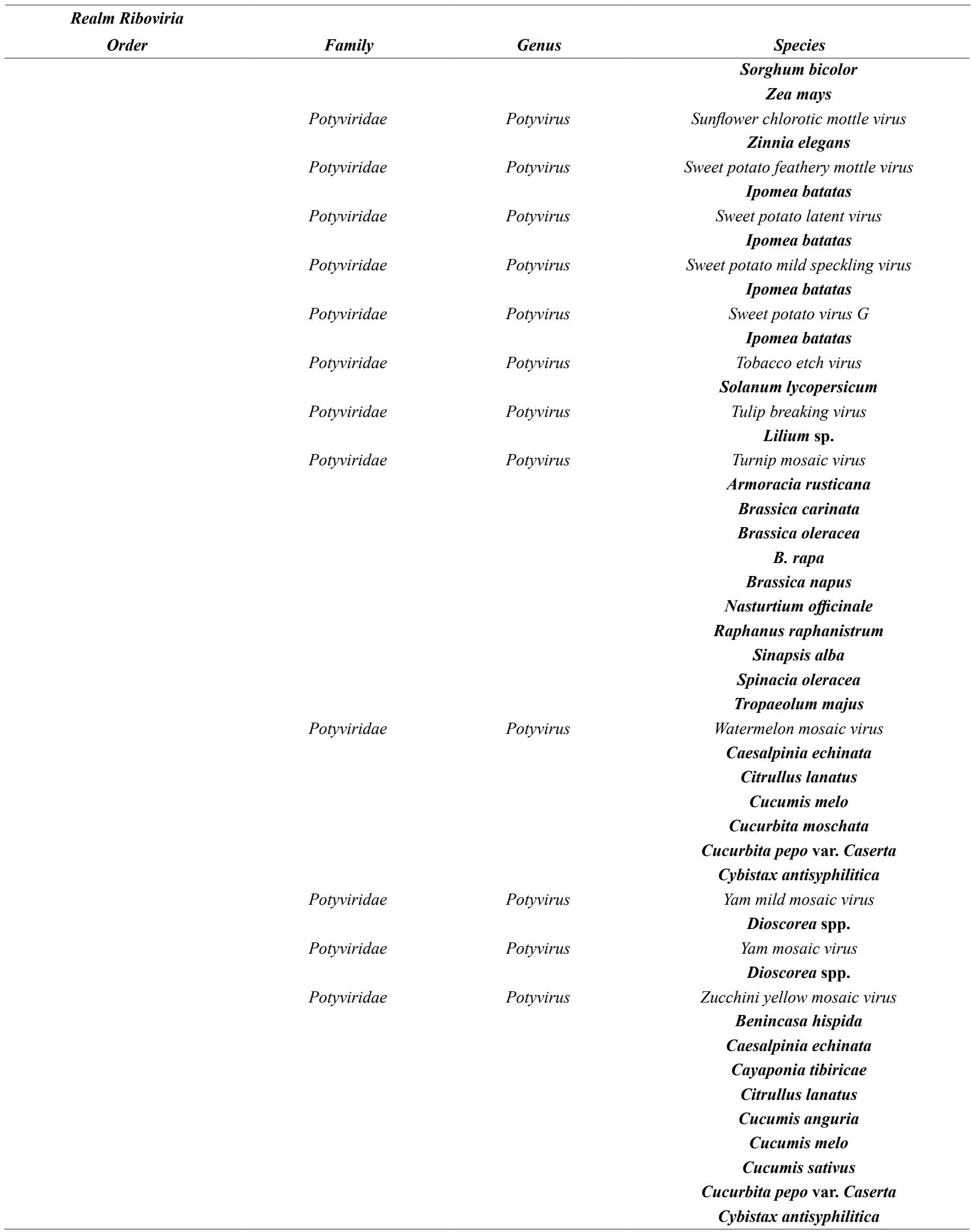


Kitajima EW

Continuation Table 1.

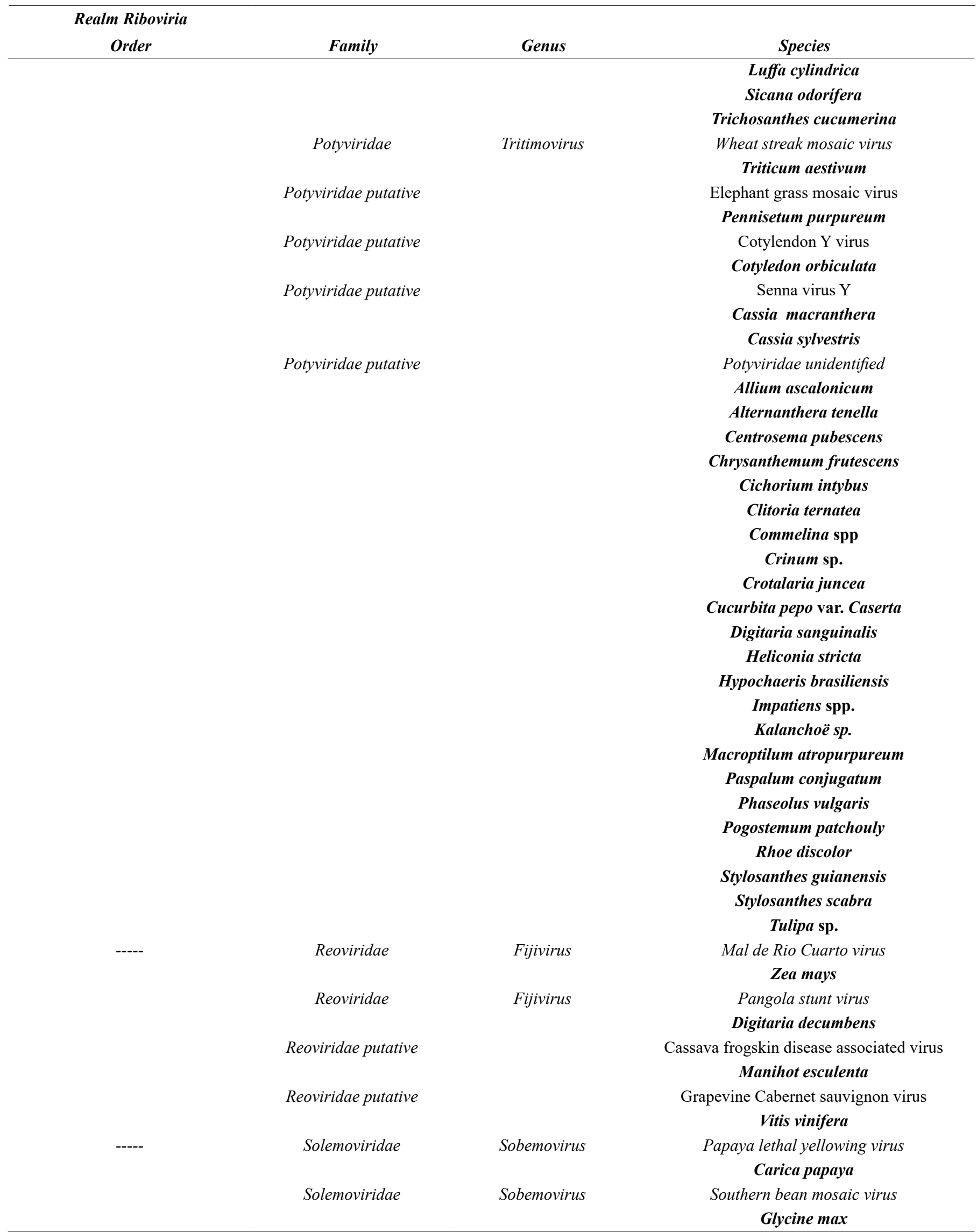


Continuation Table 1.

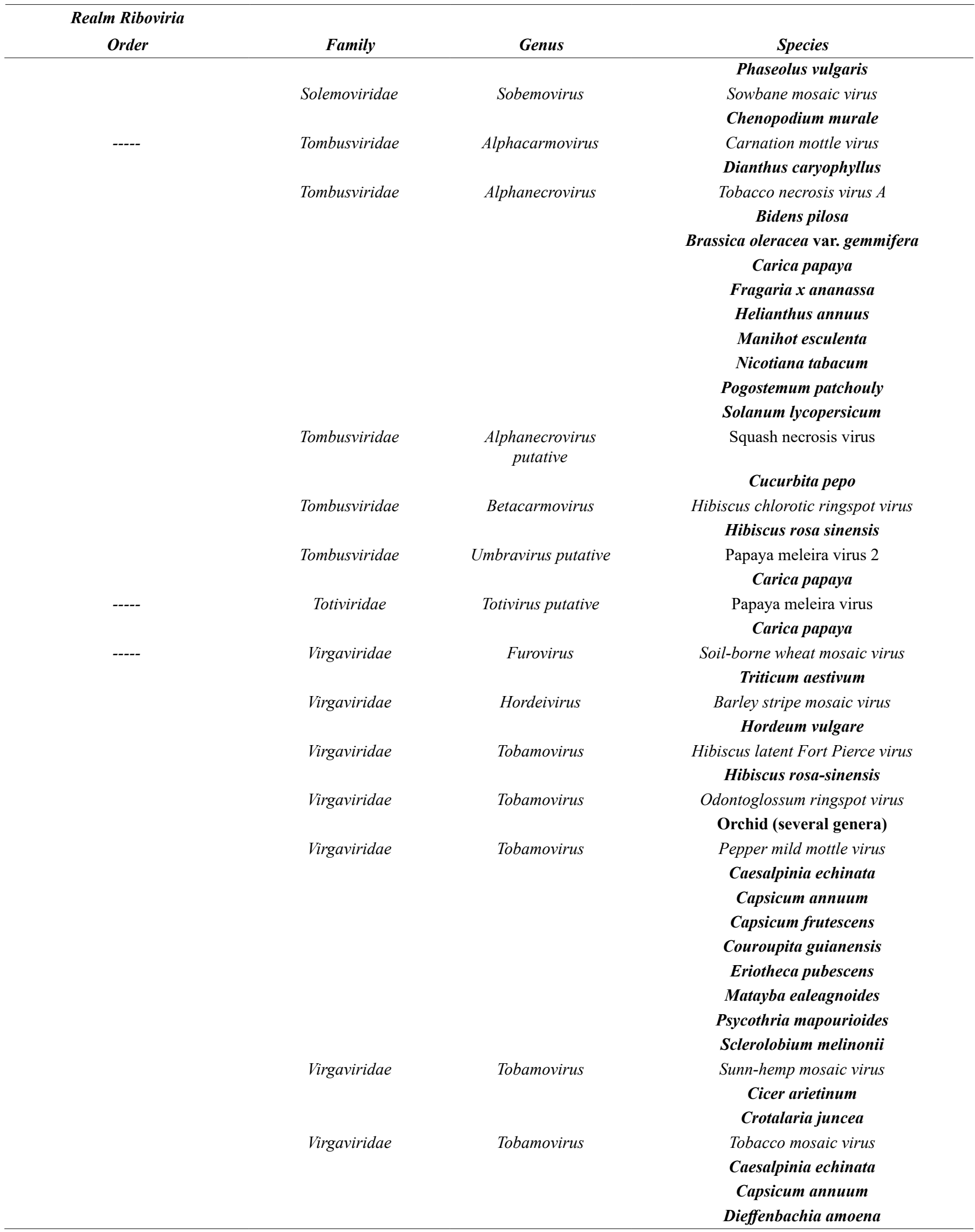


Kitajima EW

Continuation Table 1.

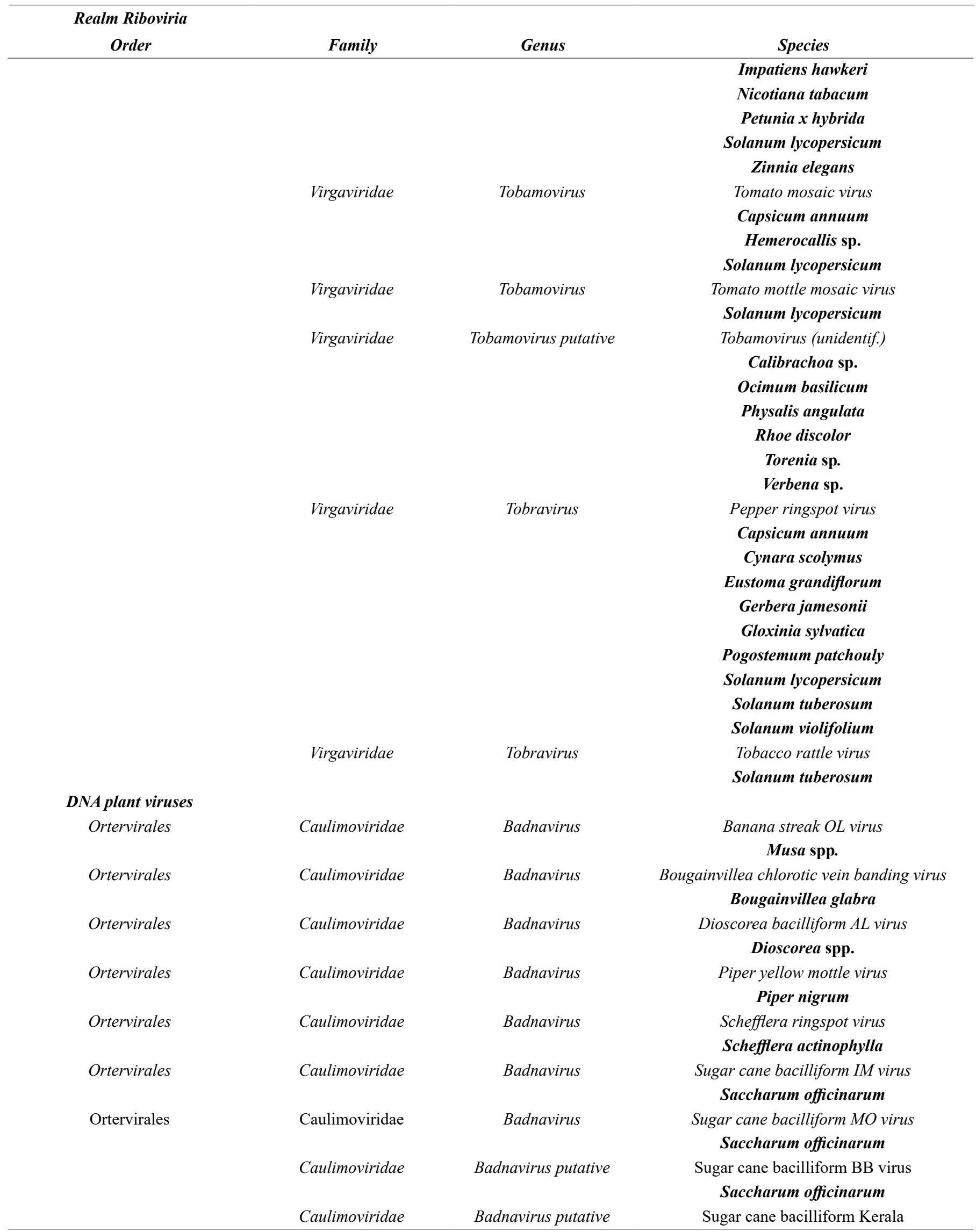


Continuation Table 1.

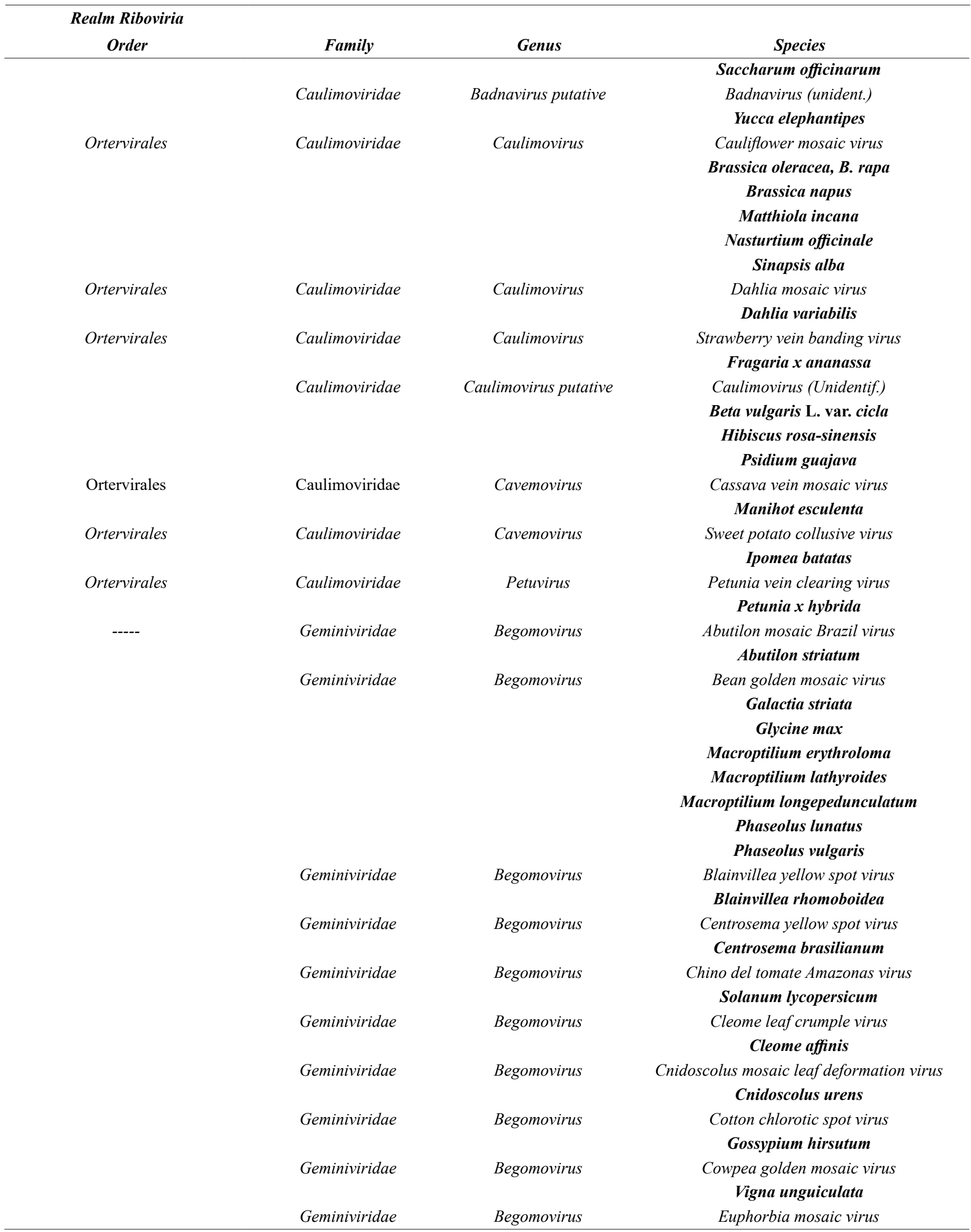


Kitajima EW

Continuation Table 1.

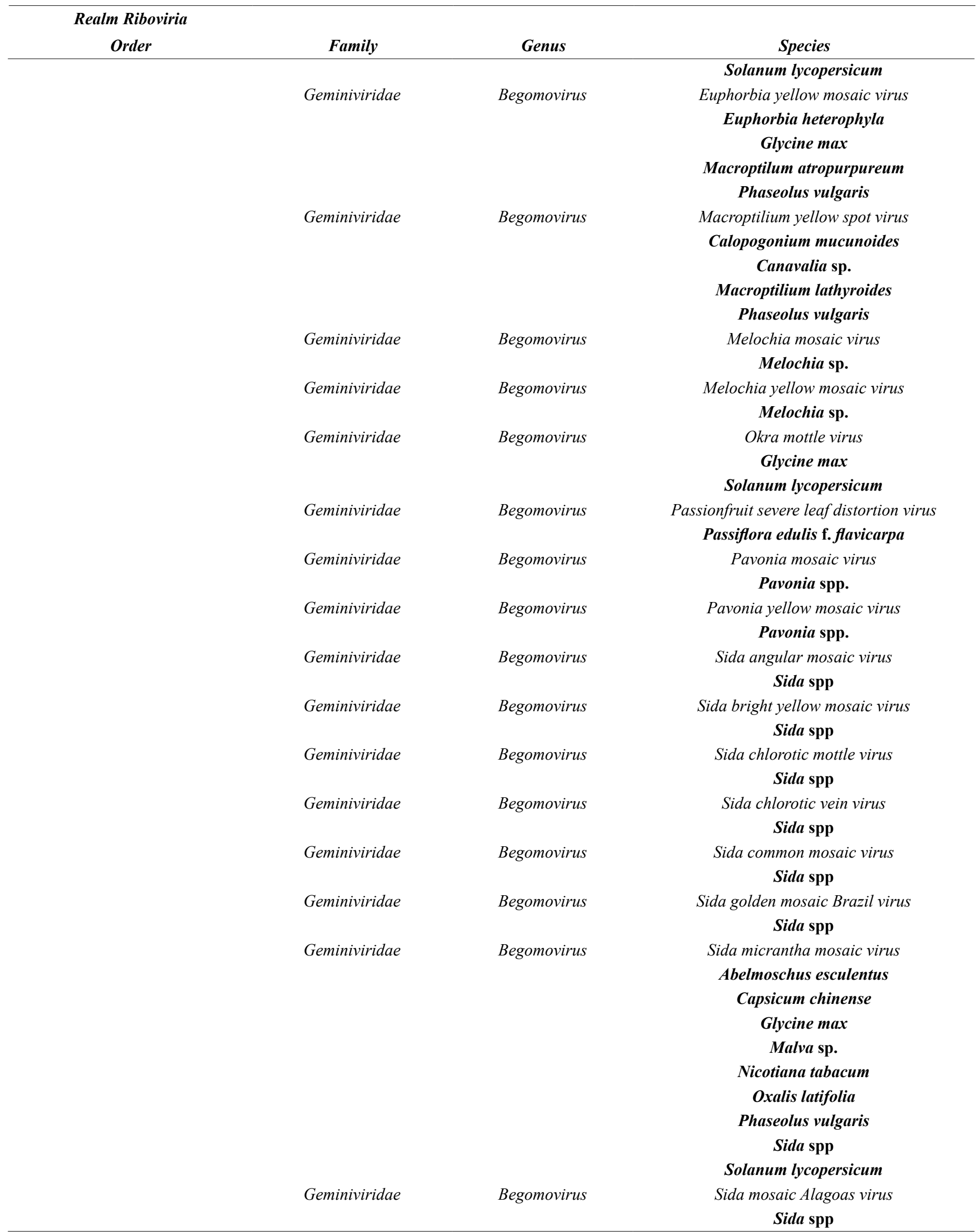


List of plant viruses and viroids in Brazil

Continuation Table 1.

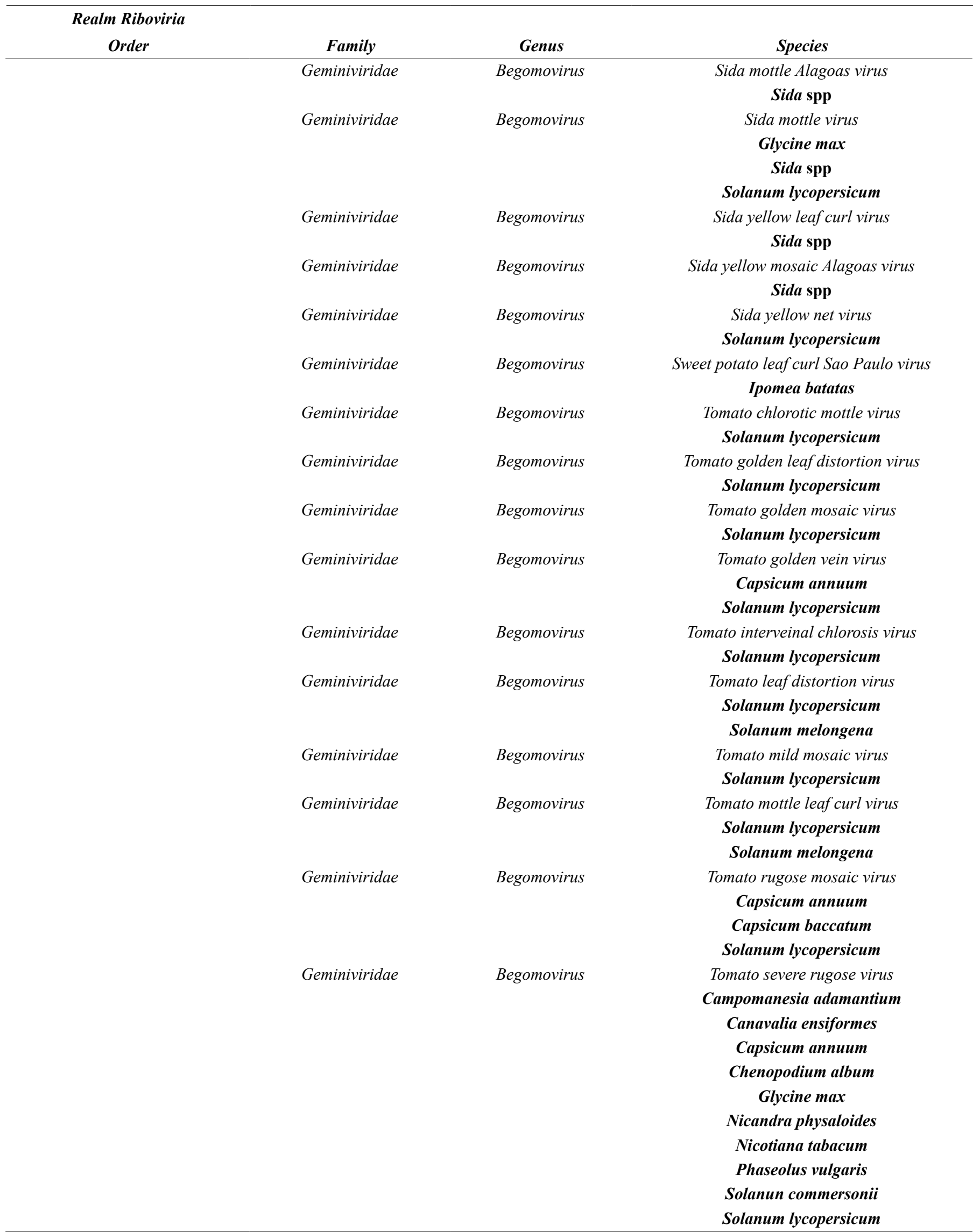


Kitajima EW

Continuation Table 1.

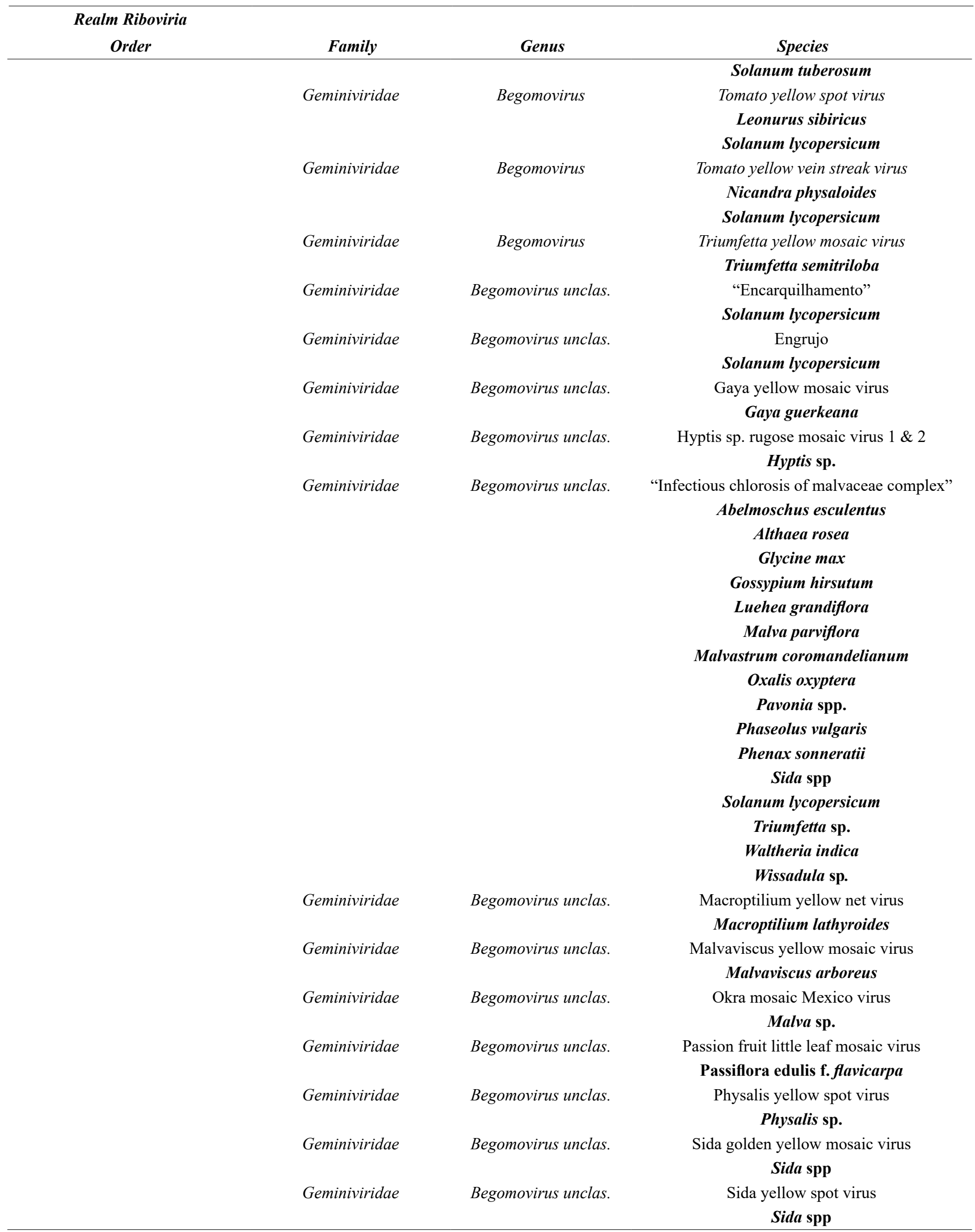


List of plant viruses and viroids in Brazil

Continuation Table 1.

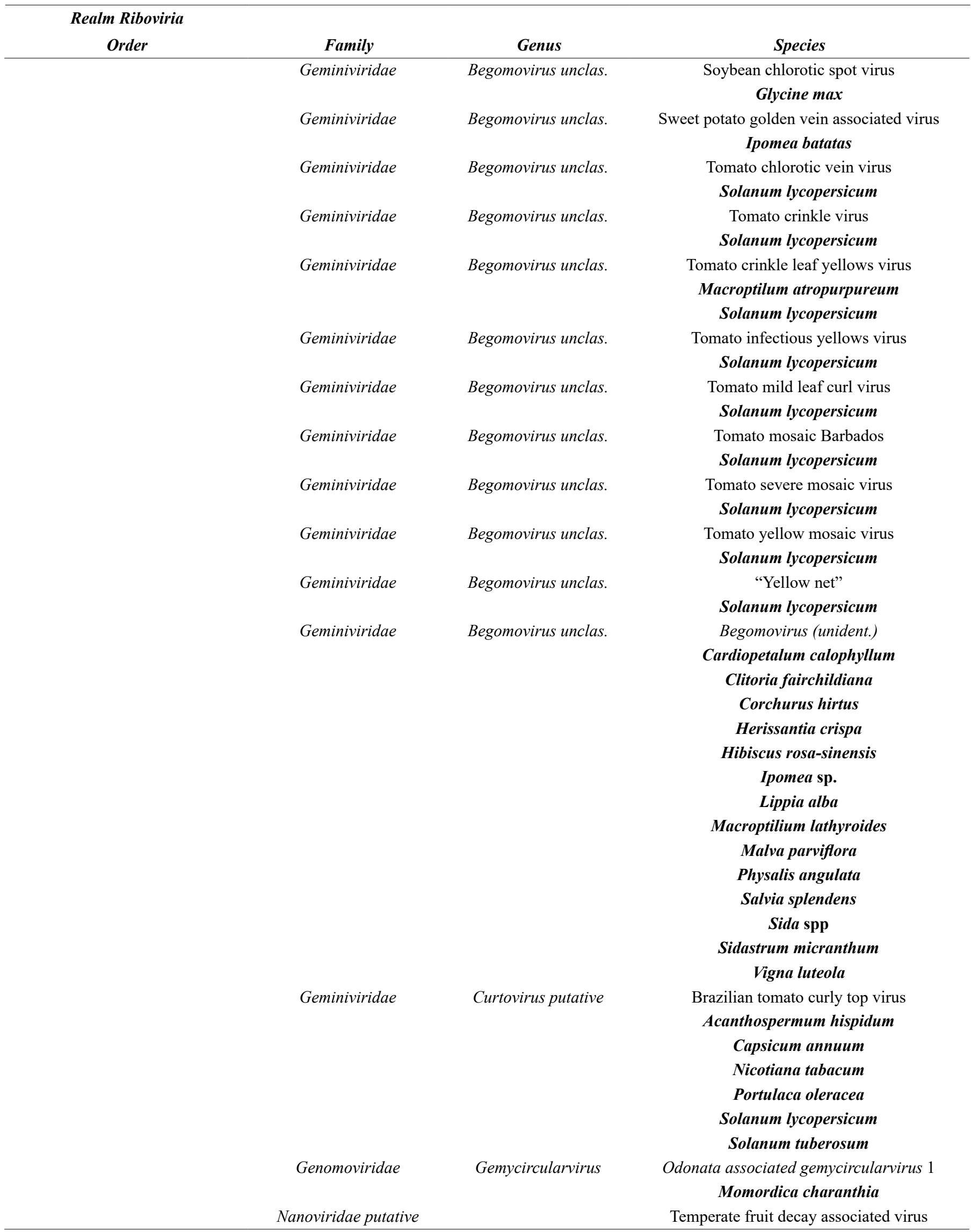


Kitajima EW

Continuation Table 1.

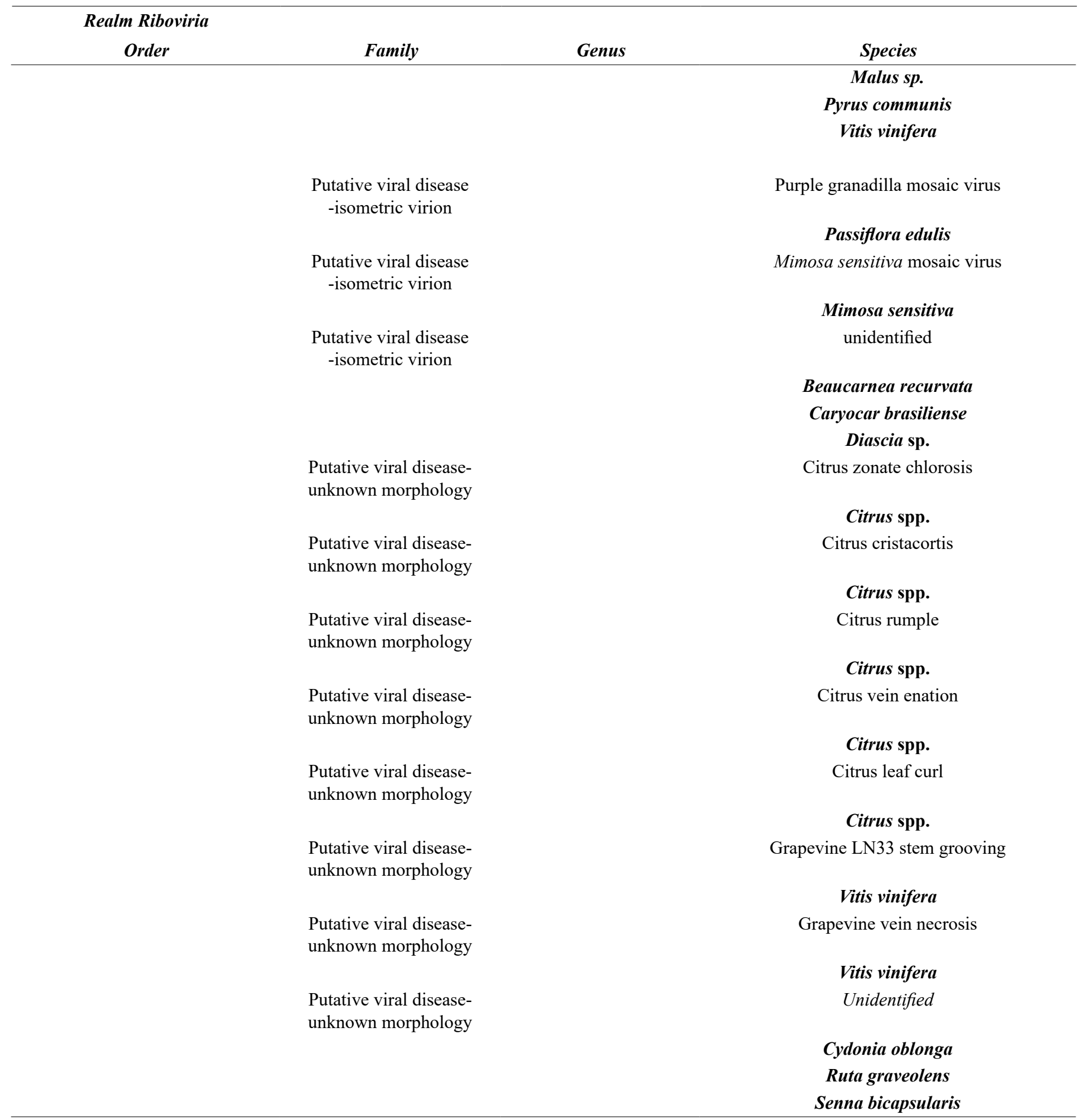

\section{*Aeschynanthus pulmer (Blume) G. Don. (Lipstick plant) Gesneriaceae \\ Cucumovirus \\ Cucumber mosaic virus (CMV) \\ Chlorotic spots on lipstick plant leaves were found to be caused by CMV infection in the state of São Paulo. There is no information regarding losses (1).}

Ref.: (1) Alexandre, M.A.V. et al (ed). Plantas Ornamentais: Doenças e Pragas. 319pp. 2008.

\section{*Allamanda cathartica Schott. (Golden trumpet) Apocynaceae Dichorhavirus}

Dichorhavirus unidentified

Chlorotic spots were found on leaves of golden trumpet plants in a residential garden in Manaus, AM. Transmission electron microscopy revealed the presence of cytopathic effects characteristics of those caused by nuclear type of Brevipalpus-transmitted viruses. This 
possible dichorhavirus remains unidentified (1).

Ref.: (1) Rodrigues, J.C.V. et al. Trop. Plant Pathol 33: 12. 2008.

Cucumovirus

\section{Cucumber mosaic virus (CMV)}

Ringspot symptoms on leaves of golden trumpet plants were observed in SP $(1,2)$ and DF (3). Flowers tend to drop prematurely in the affected plants. There is no data on losses. The causal agent was identified as CMV, which was transmitted experimentally by mechanical means and by aphids.

Ref.: (1) Silberschmidt, K. \& Herbas, R. Zentralbl. Bakt. Parasit. Infektionskrank.Hygiene 123: 330-335. 1969; (2) Alexandre, M.A.V. et al (ed). Plantas Ornamentais: Doenças e Pragas. 319pp. 2008.(3) Rodrigues, M.G.R. et al. Fitopatol.bras. 9: 151-155. 1984.

\section{*Allium ascalonicum Baker (Green onion) Liliaceae \\ Carlavirus and Potyvirus \\ Carlavirus and Potyvirus, unidentified}

Carlavirus and potyvirus were detected in green onion showing symptoms of chlorotic stripes in São Paulo, SP. These viruses, however, were not identified at species level (1).

Ref.: (1) Colariccio, A. et al. Virus Rev.\& Res. (Res. VII ENV p. 281). 1996

\section{*Allium cepa L. (Onion) Liliaceae Orthotospovirus \\ Iris yellow spot virus (IYSV)}

The first report of IYSV infecting onion in Brazil occurred in a sample of onion cv. 'Pêra Baia' from Rio Grande, RS, showing elliptical lesions with chlorotic center and depressed/necrotic margins, referred to as 'sapeca' by growers. Causal agent was identified as a Orthotospovirus (1). Later similar disease was observed in onion fields in Petrolina, PE, also known locally as 'sapeca'. Further works identified the causal Orthotospovirus, distinct from others previously describes in Brazil, as IYSV, originally found infecting Iris sp. $(2,3)$. The vector was identified as Thrips tabaci (4)

Ref.: (1) de Ávila, A.C. et al. Fitopatol.bras. 6: 535. 1981; (2) Pozzer, L. et al. Fitopatol. Bras. 19: 321, 1994; (3) Plant Dis.83: 345. 1999; (4) Nagata, T. et al. Plant Dis. 83: 399. 1999.

Potyvirus

\section{Onion yellow dwarf virus (OYDV)}

The first report of yellow stripe mosaic along the leaf and stunting symptoms in onion was made in Piedade and Santa Cruz do Rio Pardo, SP, and in Belo Horizone, MG. These symptoms were known locally as 'crespeira'. The causal agent was identified as OYDV (1), later confirmed by immunological and molecular techniques $(3,4)$. There are reports of distinct varietal response in onion infected by OYDV (2) Ref.: (1) Costa, A.S. et al. Rev.Olericult. 3: 67. 1966; (2) Assis, M.I.T. et al. Fitopatol. Bras. 18: 287. 1993 ;(3) Fitopatol.bras. 20: 469.1995; (4) Muller,N.T.G. \& Daniels, J. Fitopatol.bras. 25: 445. 2000.

\section{*Allium fistulosum L. (Bunching onion) Liliaceae Potyvirus Onion yellow dwarf virus (OYDV)}

Stripe mosaic, less severe than that observed in onion, was observed in bunching onion. Plants became chlorotic and less vigorous, and leaves may become curved down. The first report was made in samples from Campinas, SP, and the causal agent, identified as an isolate of OYDV, transmitted by aphids and perpetuated by vegetative reproduction. Infected plants may serve as source of inoculum of OYDV for nearby onion plantations (1).

Ref.: (1) Costa, A.S. et al. O Biológico 37: 158. 1971.
*Allium sativum L. (Garlic) Liliaceae

Allexivirus

Garlic virus $A$ (GarV-A)

Garlic virus B (GarV-B)

Garlic virus C (GarV-C)

Garlic virus D (GarV-D)

Garlic virus $X$ (GarV-X)

Garlic mite-borne filamentous virus (GarMbFV)

A complex of these allexviruses was found in garlic samples in several Brazilian states (DF, GO, BA, MG and RS) by molecular detection (1-3).

Ref.: (1) Melo Fo, PA et al. Fitopatol.bras. 26: 535. 2001; (2) FayadAndré, MS. et al. Trop.Plant Pathol. 36: 341. 2011; (3) Oliveira, M.L. et al. Trop.Plant.Pathol. 39: 483. 2014.

\section{Carlavirus}

\section{Garlic common latent virus (GarCLV)}

Dusi et al. (1) reported the presence of a carlavirus in ca. $60 \%$ of the sampled asymptomatic garlic plants, representing several cultivars, in the DF, in a serological survey. The virus was identified molecularly as GarCLV (2), which is part of the viral complex found infecting garlic (3). GarCLV was also found in samples collected at BA and MG (4) and PR and SP (5).

Ref.: (1) (1) Dusi, A.N. et al. Fitopatol.bras. 19: 298. 1994; (2) Fajardo, T.V.M. et al. Virus Rev. \& Res. 2: 191. 1997 ; (3) Fitopatol.bras. 26: 619. 2001; (4) Fayad-André, MS. et al. Trop.Plant Pathol. 36: 341. 2011; (5) Mituti, T. Diss.Mestrado, IAC. 2009.

\section{Shallot latent virus (SLV)}

First detection of SLV infecting garlic in Brazil was made by RTPCR assays in samples collected in the states of SP and PR (1).

Ref.: (1) Mituti, T et al. Plant Dis. 95: 227. 2011..

Potyvirus

\section{Onion yellow dwarf virus (OYDV)}

Leek yellow stripe virus (LYSV)

Yellow stripe symptoms on garlic leaves were found to be caused by OYDV and/or LYSV infection initially in the state of RS (1). These potyviruses occur usually as a part of a viral complex (poty-, carlaand allexivirus) present in garlic which significantly reduces garlic yield. Attempts to produce virus-free garlic plants resulted in high yields both qualitative- and quantitatively (2). Identification of OYDV and LYSV infecting garlic was made by serological $(3,4)$ or molecular means (5) in samples from DF. Garlic isolate of OYDV apparently does not infect onion and vice-versa. LYSV has been detected in garlic samples from several parts of Brazil (6). Co-infection of LYSV and OYDV has been found in the states of BA and GO (7), PR, MG and SP (8). Genome of a garlic isolate of LYSV was entirely sequenced (9). Serological assays demonstrated that noble garlics were co-infected by OYDV and allexiviruses, in Itajai, SC (10).

Ref.: (1) Daniels, J. et al. Fitopatol.bras. 2: 82. 1978; (2) Carvalho, M.G. Inf. Agropec. 12: 41. 1986; (3) Assis, M.I.T. et al. Fitopatol. bras. 18: 288. 1993; (4) Dusi, A.N. et al. Fitopatol.bras. 29: 298. 1994; (5) Fajardo, T.V.B. et al. Fitopatol.bras. 26: 619. 2001; (6) FayadAndré,MS et al. Virus Rev. \& Res. 14(supl): 60. 2009; (7) FayadAndré, MS. et al. Trop.Plant Pathol. 36: 341. 2011; (8) Mituti, T. Diss. Mestrado, IAC. 2009; (9) Bampi, D. et al. Summa Phytopathol 40 (supl.), CDRom. 2014; (10) Araújo, ER et al. Summa Phytopathol. 44: 195. 2018

\section{*Alocasia sp., Alocasia macrorhizos (L.) Schott. (Taro) Araceae Potyvirus}

Dasheen mosaic virus (DsMV)

Surveys made in the Federal District (DF) detected DsMV, by biological assays and electron microscopy, infecting taro (Alocasia spp.), exhibiting mosaic symptoms (1). 
Ref.: (1) Rodrigues, M.G.R. et al. Fitopatol.bras. 9: 291. 1984.

\section{*Alstroemeria sp. (Peruvian lily) Alstroemeriaceae}

Orthotospovirus

Chrysanthemum stem necrosis virus (CSNV)

Tomato spotted wilt virus (TSWV)

Peruvian lily plants showing necrotic lines and rings were observed in the city of São Paulo, SP, and found to be infected by CSNV or TSWV $(1,2)$.

Ref.: (1) Duarte, L.M.L. et al. Rev. Bras. Hort. Orn. 5: 24.1999; (2)

Duarte, L.M.L. Virus Rev. Res. 6: 50. 2001

Carlavirus

\section{Carlavirus unidentified}

Chlorotic bands on the leaves of Peruvian lily found in São Paulo, SP, was found associated with the presence of an unidentified carlavirus. Ref.: (1) Seabra, P.V. et al. Arq. Inst. Biol. (supl.) 64: 61. 1997.

Cucumovirus

\section{Cucumber mosaic virus (CMV)}

Natural infection of Peruvian lily by CMV was verified in the city of São Paulo, SP, resulting in mosaic, chlorotic spots and bands, as well as thin leaves (1-3).

Ref.: (1) Costa, A.S. Summa Phytopathol. 9: 39. 1983; (2) Duarte, L.M.L. et al. Rev. Bras. Hort. Orn. 5: 24..1999; (3) Tombolato, A.F.C. et al. Cultivo commercial de plantas ornamentais, 22p. 2004.

Ilarvirus

\section{Tobacco streak virus (TSV)}

Serological tests found TSV associated to chlorosis, necrotic spots and stripes on the leaves of Peruvian lily in São Paulo, SP (1).

Ref.: (1) Duarte L.M.L. et al. Rev. Bras. Hort. Orn. 5: 24.1999.

Potyvirus

\section{Alstroemeria mosaic virus (AlsMV)}

A potyvirus was detected in Peruvian lily with thin leaves, vein banding and color breaking in the flowers in São Paulo, SP $(1,2)$. More recently this virus was identified as AlsMV by RT-PCR (3).

Ref.: (1) Alexandre, M.A.V. et al. Res. X Cong. Bras. Floric. Plant. Ornam. 69. 1995; (2) Duarte, L.M.L. et al. Rev. Bras. Hort. Orn. 5: 24. 1999; (3) Rivas,E.B. et al. Summa Phytopathol. 39 supl. CDRom. 2013.

\section{*Althaea rosea Cav. (Common hollyhock) Malvaceae \\ Begomovirus}

Infectious chlorosis of malvaceae complex (ICMC)

A bright yellow mosaic in common hollyhock was described in São Paulo, SP. The causal agent was transmitted by whitefly and considered as part of ICMC $(1,2)$

Ref.: (1) Costa, A.S. Phytopathol. Zeit. 24: 97. 1955; (2) Silberschmidt, K. \& Tommasi, L.R. Ann. Acad. Bras. Cien. 27: 195. 1955.

\section{*Alternanthera tenella Colla (Joseph's coat) Amaranthaceae Potyvirus \\ Potyvirus unidentified}

Mosaic symptoms in A. tenella were noticed in the state of Paraná, associated with an uncharacterized potyvirus, which caused local lesions in Chenopodium amaranticolor and C. quinoa (1). Serological assays revealed relatioship with PVY but differs in the CP sequence with PVY and other potyviruses (2).

Ref.: (1) Fukushigue, C.Y. et al., Fitopatol.bras. 17: 209. 1992; (2) Fitopatol.bras. 25: 441. 2000.

\section{*Amaranthus sp. (Amaranth) Amaranthaceae \\ Orthotospovirus \\ Orthotospovirus unidentified}

Arching, roughness, vein clearing, chlorotic spots, necrotic rings and curly top symptoms in amaranth were found associated to infection by an unidentified Orthotospovirus in the state of São Paulo (1).

Ref.: (1) Costa, A.S. \& Forster, R. Bragantia 2: 83. 1942.

Potyvirus

\section{Potato virus Y (PVY)}

Natural infection of amaranth by an isolate of PVY, without mention of symptoms, was reported in the state of Minas Gerais (1). Ref.: (1) Oliveira, C.D. et al. Fitopatol.bras. 21: 427. 1996.

\section{*Amaranthus spinosus L. (Spiny amaranth) Amaranhaceae} Potyvirus Zucchini yellow mosaic (ZYMV)

During a survey of viruses in cucurbit producing areas in the state of Tocantins, ZYMV was found infecting A. spinosus, part of the spontaneous vegetation surrounding cucurbit fields, in the municipality of Lagoa da Confusão (1).

Ref.: (1) Aguiar, R.W.S et al. Planta Daninha 36: :e018171593. 2018.

\section{*Ambrosia elatior L. (Ragweed) Asteraceae \\ Polerovirus \\ Potato leafroll virus (PLRV)}

There is a report of infection of ragweed by PLRV in the state of Minas Gerais, without details of the symptoms (1).

Ref.: (1) Oliveira, C.D. et al. Fitopatol.bras. 21: 427. 1996

\section{*Ambrosia polystachya DC, Asteraceae \\ Ilarvirus \\ Tobacco streak virus (TSV)}

A case of natural infection of $A$. polystachya by TSV was reported in the state of São Paulo, resulting in mosaic symptoms. This is the only successful case of TSV transmission by the thrips Frankliniella sp., collected in the flowers from TSV-infected A.polystachya to tobacco and soybean. $(1,2)$.

Ref.: (1) Costa, A.S. \& Lima No., V.C. Fitopatologia 11: 11. 1976; (2) Lima No., V.C. et al. Rev. Setor Cien.Agr.UFPr 4: 1. 1982.

\section{*Amorphophallus konjac K. Koch (Konjac) Araceae \\ Potyvirus \\ Dasheen mosaic virus (DsMV)}

Yellowing, mosaic and poor root development of cultivated konjac plants was verified in the state of São Paulo. Serological assays and electron microscopy identified DsMV as the causal agent of the disease (1)

Ref.: (1) Chagas, C.M. et al. Fitopatol.bras. 18: 551. 1993.

\section{*Ampelopsis heterophylla Blume (Porcelain berry) Vitaceae Hostuviroid \\ Hop stunt viroid (HSVd)}

Molecular assays detected HSVd infecting porcelain berry during a survey of viroids in grapes (1).

Ref.: (1) Fajardo, T.V.M. et al. Australasian Plt.Dis.Notes 13: 3. 2018.

\section{*Ananas comosus (L.) Merr. (Giant pineapple) Bromeliaceae Nucleorhabdovirus \\ Nucleorhabdovirus unidentified}

Chlorotic streaks on the leaves of Giant pineapple were associated with an unidentified nucleorhabdovirus, detected by electron microscopy. This anomaly was found in Tarauacá, AC, without further information about incidence or losses (1).

Ref. (1) Kitajima, E.W. et al. Phytopahtol. Zeit. 82: 83. 1975.

\footnotetext{
*Ananas sativus Schult. (Pineapple) Bromeliaceae

Ampelovirus
} 


\section{Pineapple mealybug associated wilt virus $(\mathrm{PMWaV} \mathrm{1,} \mathrm{2,} \mathrm{3)}$}

Infection of pineapple plants by PMWaV 1 e 2 results in symptoms as leaf reddening, leaves with yellow edge, downward curling of leaf edge and drying of the leaf extremity. Plants have reduced roots and are easily pulled out. Wilting of plants occurs and may end with their death. PMWaVs are mealybug -transmitted, but not mechanically or through seeds, being pineapple their sole host plant, and the disease is wide-spread wherever pineapple is cultivated. Control of the mealybug vectors and ants associated to them and production of virusfree plants are the proposed control measures for the disease (1). First identification of these viruses in Brazil was made in the state of Bahia, based on symptomatology and electron microscopy (2). PMWaV-1 e 2 were detected in the state of Espirito Santo (3), Paraiba and Paraná (4) PMWaV-2 and 3 in the state of Rio Grande do Sul (4); PMWaV-1, 2, 3 in the states of Bahia, Minas Gerais, Mato Grosso and Pará (4). These viruses were originally classified as Closterovirus, but now are reclassified to the genus Ampelovirus (5).

Ref.: (1) Sanches et al. Murcha associada a cochonilha. In Reinhard, D.H. et al. (Ed.) Abacaxi produção- aspectos técicos. Embrapa Mandioca e Fruticultura. Comumicação para transferência de tecnologia. p.62. 2000; (2) Nickel, O. et al. Fitopat'ol.Bras. 25: 200. 2000; (3) Peron, FN et al. Trop Plat Pathol 34(supl): S267. 2009; (4) Santos, K.C. Diss.MS Univ.Fed.Rec.Bahiano 60p. 2013; (5) Mayo, M.A. Arch. Virol. 147. 2002.

\section{*Andira vermifuga Mart. Ex Benth. Fabaceae \\ Cucumovirus \\ Cucumber mosaic virus (CMV)}

A serological survey detected CMV in seedlings of $A$. vermifuga in a nursery in Brasília, DF (1).

Ref.: (1) Batista, J.G. et al. Trop.Plt.Pathol. 40(supl): res.354.2. 2015.

\section{*Angelonia sp. (Angelonia) Plantaginaceae \\ Potexvirus \\ Althernanthera mosaic virus (AltMV)}

AltMV-infected angelonia plants, exhibiting mosaic symptoms, were found in São José do Rio Preto, SP (1).

Ref.: (1) Alexandre, M.A.V. et al. Trop.Plant Pathol. 33 (supl): S291. 2008 .

\section{*Anonna muricata L. (Soursop) Anonnacea \\ Cytorhabdovirus unclassified}

\section{Soursop yellow blotch virus (SYBV)}

Plants of cultivated soursop, showing yellow blotches on their leaves, were found in Pacajús, CE. A mechanically transmissible cytorhabdovirus was identified as the causal agent of the disease being able to infect soursop and other annonacea plants experimentally (1). The virus was purified and partially characterized molecularly, but it is still unclassified (2). Epidemiological studies suggest a contagious type of disease dispersion (3). Under experimental conditions, SYBVinfected plants had significative reduction on plant size (ca. $60 \%$ in height and $40 \%$ in trunk diameter) and in fruit yield (ca. $90 \%$ in fruit number and weight) (3).

Ref.: (1) Kitajima, E.W. et al. Plant Dis. 72: 276. 1993; (2) Martins, C.R.F. et al. Fitopatol. Bras. 24: 410. 1999; (3) Santos, A.A. et al. Rev.Cien.Agron. 34: 19. 2003; (4) Santos, A.A. et al. Summa Phytopathol.30: 90. 2007.

\section{Dichorhavirus}

\section{Clerodendrum chlorotic spot virus (CICSV)}

Soursop plants showing yellow spots on the leaves were found in a backyard orchard in Catanduva, SP, associated with infestation by Brevipalpus mites. It resembled the description of similar symptoms made by Bitancourt, in 1955 (1). Ultrastructural analysis of the chlorotic lesions revealed the presence of cytopathic effects similar to that caused by the nuclear type of Brevipalpus-transmitted viruses (2). Similar symptoms were reproduced by experimental mite-infection by the ClCSV (3).

Ref.: (1) Bitancourt, A.A. Arq.Inst.Biol. 22: 161. 1955; (2) Kitajima, E.W. et al. Exp.Appl.Acarol. 30: 135. 2003; (3) Kitajima, E.W. et al. Scientia Agricola 63: 36. 2008.

*Anthurium sp., A. andreanum Lind., A. scherzerianum Schott. (Anthurium) Araceae

\section{Cucumovirus}

\section{Cucumber mosaic virus (CMV)}

CMV was detected associated to mosaic symptoms on leaves of anthurium in Mogi das Cruzes, SP (1).

Ref: (1) Miura, NS. et al. Summa Phytopathol 35:(supl) res. 043 CDRom 2009.

\section{Cilevirus}

\section{Cilevirus unidentified}

Samples of anthurium plants showing ringspots on their leaves, coming from Cruz das Almas, BA, were examined by electron microscopy. Typical cytopathic effects caused by cilevirus were observed in the tissues of affected leaf parts, suggesting that the causal agent was a cytoplasmic type of Brevipalpus-transmitted virus, a possible member of the genus Cilevirus (1).

Ref.: (1) Ferreira, P.T.O. et al. Virus Rev. Res. 9: 249. 2004.

Potyvirus

\section{Dasheen mosaic virus (DsMV)}

DsMV was found in anthurium from several commercial plantations in São Paulo, SP. The virus was detected by ELISA in anthurium plants showing leaf deformation, chlorotic and ringspots and necrotic streaks (1-4).

Ref.: (1) Rivas, E.B. et al. Virus Rev.Res. 2: 192. 1997. (2) Lima et al. Fitopatol.bras. 29: 105. 2004; (3) Tombolato, A.F.C. et al. Boletim Técnico, 194, 47p. 2002.. (4) Tombolato, A.F.C. et al. (Ed.) Cultivo commercial de plantas ornamentais. p61. 2004.

\section{*Apium graveolens L. (Celery) Apiaceae}

Ilarvirus

\section{Tobacco streak virus (TSV)}

Celery plants cv. 'Americano Dourado' were found with general yellowing and/or chlorotic spots on their leaves, in Mogi das Cruzes, SP. General yellowing was considered a varietal characteristic but the yellow spots were attributed to the infection by TSV. Comparative infection assays revealed differences in TSV susceptibility among the several tested cultivars. (1).

Ref.: (1) Costa, A.S. Summa Phytopathol. 14: 57. 1988

Potyvirus

\section{Celery mosaic virus (CeMV)}

Bright yellow mosaic and reduction in the plant size were observed in cultivated celery in the state of São Paulo. Electron microscopy indicated the presence of a possible potyvirus, which induced a characteristic large, fibrous nuclear inclusion. It was transmitted mechanically to celery and several assay plants and was named Celery yellow mosaic virus (1). It was also transmitted by aphids and was able to infect some other apiaceae plants $(2,3)$. The virus was also found in the Federal District and states of Rio de Janeiro (4) and Paraná (5). It is serologically related to the Celery mosaic virus (CeMV) described in Europe, being possibly an isolate (6). It was also found infecting naturally parsley in Piracicaba, SP (7). A large scale comparison of genomes of other apiaceae potyviruses indicated a close similarity with a virus found in wild Daucus from Australia, considered CeMV, also inducing nuclear fibrous inclusion (8).

Ref.: (1) Kitajima, E.W. \& Costa, A.S. Bragantia 27: VII; IX. 1968; 
(2) Oliveira, M.L. \& Kitajima, E.W. Fitopatol. Bras. 6: 35. 1981; (3) Oliveira, M.L. et al. Fitopatol.bras. 6: 57. 1981; (4) 6: 105. 1981; (5) Lima, M.L.R.Z.C. et al. Fitopatol.bras. 9: 403. 1984; (7) Novaes, Q.S. et al. Summa Phytopathol. 26: 250. 2000; (8) Moran, J. et al. Arch. Virology 147: 1855. 2002.

\section{*Arachis hypogaea L. (Groundnut, peanut) Fabaceae Orthotospovirus \\ Groundnut ringspot virus (GRSV)}

GRSV was detected by immunoassays in accessions of Arachis sp., used as green coverage in the Carpina Experimental Station of the UFRPe (1). A high incidence of groundnut plants with mosaic, ringspots, necrosis and reduction of the leaf size was noticed in a commercial plantation in Itapolis, SP. The causal agent was identified as GRSV based on laboratory assays (electron microscopy, RT-PCR, biological assays) (2).

Ref.: (1) Andrade, G.P. et al. Fitopatol.bras. 28: S246. 2003; (2) Camelo-Garcia, V.M. et al. J.Gen.Plt.Pathol. 80: 282. 2014.

Tomato spotted wilt virus (TSWV)

Symptoms of top necrosis, rosette at the stem's end, reduced size of plants, leaves with mosaic and ringspots were observed in an experimental plot of Instituto Agronomico, in Campinas, SP, and attributed to infection by TSWV (1). A confirmation of the virus identity was achieved later using serology and molecular techniques (2).

Ref.: (1) Costa, A.S. O Biológico 7: 248. 1941; Bragantia 10: 67. 1950: (2) Andrade, G.P. et al. Fitopatol. Bras. 21: 421.1996

Potyvirus

Bean yellow mosaic virus (BYMV)

A mild mosaic in groundnut caused by an isolate of BYMV, which was severe to bean plants, was identified in the state of S.Paulo (1).

Ref.: Costa, A.S. et al. Anais I Simp.Bras.Feijão (Campinas). p. 305. 1972;

\section{Cowpea aphid-borne mosaic virus (CABMV)}

Groundnut plants showing mosaic symptoms were observed in the state of Paraiba, and initially considered cause by Peanut stripe virus (isolate of Bean common mosaic virus) (1). However, following works identified the virus as CABMV (2).

Ref.: (1) Pio Ribeiro, G.P. et al. Fitopatol.bras. 19: 329. 1994; (2) Andrade, G.P. et al. Fitopatol.bras. 24: 261. 1999.

\section{Peanut mottle virus (PeMoV)}

An aphid-borne and mechanically transmissible potyvirus was found associated with symptoms of mosaic or mottling on groundnut leaves in the states of São Paulo $(1,3)$ and Paraíba (2). The causal virus was identified as PeMoV.

Ref.: (1) Costa, A.S. \& Kitajima, E.W. Fitopatologia 9: 48. 1974; (2) Pio Ribeiro, G.P. et al. Fitopatol.bras. 19: 329. 1994; (3) Andrade, G.P. et al. Fitopatol. bras. 21: 421.1996

\section{*Arachis pintoi Krapov \&Gregory (Pinto peanut) Fabaceae Carlavirus \\ Cowpea mild mottle virus (CMMV)}

An isolate of CMMV was found infectig A.pintoi, in the state of Paraná (1).

Ref.: (1) Mituti, T. et al. An.Jornada Acad.Embrapa Soja. 2005.

\section{Potyvirus}

\section{Peanut mottle virus (PeMoV)}

Pinto peanut plants of an experimental plot of Embrapa Cerrados (Planaltina, DF) appeared with chlorotic ringspot on their leaves. Biological and serological assays, complemented by electron microscopy identified the causal agent as PeMoV (1).

Ref.: (1) Anjos, J.R.N. et al. Fitopatol.bras. 23: 71. 1998

\section{*Arachis repens Handro (Creeping peanut) Fabaceae} Cucumovirus

\section{Cucumber mosaic virus (CMV)}

Creeping peanut plants showing mosaic and ringspot on their leaves were found in a garden in Brasília, DF. Causal agent was identified as CMV based on biological, immuno, molecular assays and electron microscopy (1).

Ref.: (1) Kitajima, E.W. et al. Summa Phytopathol. 29. 2003.

\section{*Armoracia rusticana G. Gaertn., B. Mey.\& Scherb. (Horseradish) Brassicaceae \\ Carlavirus \\ Cole latent virus (CoLV)}

Horseradish plants showing mosaic symptoms, found in Divinolândia, SP, was found to be coinfected by Turnip mosaic virusTuMV (potyvirus) and CoLV (1).

Ref.:(1) Eiras,M. et al. Trop.Plant Pahol. 33(supl): S250. 2008.

Potyvirus

\section{Turnip mosaic virus (TuMV)}

TuMV was found naturally infecting horseradish, producing mosaic symptoms in Divinolândia, SP (1).

Ref.: (1) Eiras, M. et al. Summa Phytopathol. 33 (supl): S45. 2007.

\section{*Arracacia xanthorhiza Bancoft ("White carrot") Apiaceae Cytorhabdovirus \\ Cytorhabdovirus unidentified}

A still unidentified cytorhabdovirus was found by NSG assay in a sample of $A$. xanthorhiza from the germplasm bank of Embrapa Hortaliças (Brasília, DF). It was phylogenetically close to the Alfalfa dwarf virus- ADV (1).

Ref.: (1) Gomes, S.S. et al. Virus Review \& Res. 21: 142. 2016.

Vitivirus

Arracacha virus V(ArVV)

A possible new vitivirus was found in A. xanthorhiza, from the Germplasm Bank of Embrapa Hortaliça (Brasília, DF) by NGS. It is not associated with external symptoms and no evidence of transmission is available (1). This virus had its entire genome sequenced and revealed to be a new species in the genus vitivirus, and the name Arracacha virus $\mathrm{V}$ has been suggested (2).

Ref.: (1) Oliveira, L.M. et al. Virus Review \& Res. 21:130. 2016; ; (2) Oliveira, L.M. et al. Arch.Virol. 162: DOI 10.1007/s00705-0173326-0.2017.

Closterovirus

\section{Arracacha virus 1 (AV-1)}

NSG of samples of A. xanthorhiza from the Germplasm Bank of Embrapa Hortaliças (Brasília, DF) detected a still unidentified closterovirus. It seems closely related to the Beet yellows virus- BYV and to the Grapevine leafroll-associated virus 2- GLRaV-2) $(1,2)$. Complete sequencing of the genome of this virus revealed that it is distinct from known closteroviruses, hence the name AV-1 is being proposed (3).

Ref.: (1) Costa, G.A. et al. Virus Review \& Res. 21: 138. 2016; (2) Oliveira, L.M. et al. Arch.Virol. 162: 2141. 2017; (3) Orílio, A.F. et al. Arch.Virology 163: 2547. 2018.

Potyvirus

\section{Arracacha mottle virus (ArMoV)}

A mosaic affecting A. xanthorhiza was observed in experimental field of Embrapa Hortaliça (Brasília, DF). Further studies indicated that it was caused by a still undescribed species of potyvirus (1). Its complete genome was sequenced and the virus named ArMoV (2). Ref. (1) Orílio, A.F. et al. Fitopatol.bras. 32 (supl): S194. 2007. Orílio, A.F. et al. Arch.Virol. 158:291. 2013.

Bidens mosaic virus (BiMV) 
BiMV was found naturally infecting $A$. xanthorhiza causing mosaic symptoms in the experimental field of Embrapa Hortaliça (Brasília, DF) (1).

Ref.: (1) Orílio, A.F. et al. Plant.Dis. 101: 262. 2017.

\section{*Asclepias curassavica L. (Milkweed) Apocynaceae Cucumovirus}

\section{Cucumber mosaic virus (CMV)}

Chlorotic spots and bands were observed in leaves of milkweed in a sample collected at Itaquera, SP. Causal agent was identified as CMV (1).

Ref.: (1) Silberschmidt, K. Plant Dis.Reptr. 39: 555. 1955.

\section{*Avena sativa L. (Oat) Poaceae \\ Luteovirus \\ Barley yellow dwarf virus PAV (BYDV-PAV)}

General chlorosis and stunting in oats was identified as being caused by aphid-borne BYDV-PAV. The disease was registered in the states of Rio Grande do Sul $(1,2)$ and Paraná (3). Yield losses were evaluated in the state of Rio Grande do Sul (4).

Ref.: (1) Deslandes, J. Agros 2 (2): 88. 1949; (2) Caetano, V.R. Rev. Soc.Bras.Fitopatol. 2: 53. 1968; Tese Doutorado, ESALQ/USP, 75p. 1972; (3) Barbosa, C.J. et al. Fitopatol.bras. 18: 292. 1993; (4) Nicolini, F. et al. Fitopatol.bras.27: S210. 2002.

\section{B}

\section{*Bambusa vulgaris Schrad. (Bamboo) Poaceae Potexvirus \\ Bamboo mosaic virus (BaMV)}

Chlorotic spots and mosaic symptoms were observed in bamboo plants, without apparent damage, in a botanical collection at the Biological Expt. Sta. of the Universidade de Brasília. Biological assays and electron microscopy detected a potexvirus, name BaMV (1). It was subsequently purified and a specific antiserum was produced (2). The virus was afterwards found in Taiwan where was causing losses in bamboo shoot production (3).

Ref.: (1) Kitajima, E.W. et al. Phytopathol.Zeit. 90: 180. 1977; (2) Lin, M.T. et al. Phytopathology 67: 1439. 1977; (3) Lin, N.S. et al., Plant Dis. 77: 448. 1993.

\section{*Beaucarnea recurvata Lem. (Ponytail palm) Dracenaceae Unidentified isometric virus \\ Mosaic symptoms in ponytail palm was associated with the presence of unidentified isometric viruslike particles in leaf extracts (1).}

Ref.: (1) Alexandre, M.A.V. et al. Rev.Bras.Hort.Ornam. 16: 95. 2010.

\section{*Beaumontia grandifolia Wall. (Easter lily vine) Apocynaceae Cilevirus \\ Cilevirus unidentified}

Green spots on senescent leaves of $B$. grandifolia were observed in the campus of the Agricultural College (ESALQ) of the Universidade de São Paulo, Piracicaba, SP, associated with the presence of Brevipalpus mites. Electron microscopy revealed cytopathic effects caused by the cytoplasmic type of Brevipalpus-transmitted virus, suggesting infection by an unidentified cilevirus. (1)

Ref.: (1) Kitajima, E.W. et al. Summa Phytopathol. 32 (supl): 11. 2006.

\section{*Benincasa hispida (Thunb.) Cogn. (Wax gourd), Cucurbitaceae Potyvirus \\ Zucchini yellow mosaic virus (ZYMV) \\ Wax gourd plants exhibiting mosaic and crinkle on their leaves were observed in an experimental field of the Universidade Federal}

de Minas Gerais. The plant was found to be infected by ZYMV after biological and serological assays (1).

Ref.: (1) Rocha, F.D.S. et al. Trop.Plt.Pathol. 38 (supl.): res. 376-1. 2013.

\section{*Beta vulgaris L. var. cicla (Chard) Amaranthaceae Cytorhabdovirus \\ Cytohabdovirus unidentified \\ Caulimovirus \\ Caulimovirus unidentified}

Stunting, leaves with vein clearing and necrotic spots were observed in a commercial plantation of chard in Piedade, SP. Electron microscopy revealed the presence of a cytorhabdovirus and caulimovirus, based on their morphology. Identity of these presumed viruses was not determined. (1).

Ref. : (1) Chagas, C.M. et al. Fitopatol.bras. 24: 466. 1999.

Potyvirus

\section{Turnip mosaic virus (TuMV)}

Natural infection of chard by TuMV was noticed in the state of São Paulo, resulting in mosaic symptoms. Identification was made by biological, serological and molecular assays (1).

Ref.: (1) Ribeiro Jr., M.R. et al. J.Plant Pathol. 100: 189. 2018

\section{*Beta vulgaris L., subsp. vulgaris (Beet) Amaranthaceae Benyvirus \\ Beet necrotic yellow vein virus (BNYVV)}

In november, 2012, during a survey made in the region of São José do Rio Pardo, SP, table beet plants showing severe symptoms of rhizomania (excessive growth of the root system), without obvious symptoms in the aerial parts, were found. RT-PCR assays using specific primers for BNYVV produced nucleotide fragments, with 9397\% identity with BNYYV type A, described in the literature. The virus was able to be transmitted through contaminated soil (1). The soil fungus Polymyxa betae was found in the soil where BNYVVinfected plants occurred, and experimentally demonstrated to vector BNYYV (2).

Ref.: (1) Rezende, JAM et al. Plant Dis. 99: 423. 2015; (2) CameloGarcia,V. et al. Cong.Paul. Fitopat. res.94, 2017.

\section{*Bidens pilosa L. (Beggar's ticks) Asteraceae \\ Orthotospovirus \\ Orthotospovirus unidentified}

A report was made on the infection of B. pilosa by an unidentified Orthotospovirus in the state of São Paulo, without reference to symptomatology (1).

Ref.: (1) Costa, A.S. \& Forster, R. Bragantia 2: 83. 1942.

Nucleorhabdovirus

\section{Sowthistle yellow vein virus (SYVV)}

A nucleorhabdovirus was recovered from $B$. pilosa with stunting and large foliar blades in Brasília, DF. It was mechanically transmissible to several assay plants, including lettuce. Based on similarity of the host range and immunoassays with specific antiserum the virus was identified as an isolate of SYVV $(1,2)$.

Ref.: (1) Kitajima, E.W. et al. Fitopatol.bras. 16: 141. 1991; (2) Res. $13^{\circ}$ Coloq. Soc. Bras. Mic.Elet. p.59. 1991.

\section{Dichorhavirus}

\section{Dichorhavirus unidentified}

B. pilosa with chlorotic spots on the leaves were found in a residential garden in Manaus, AM, during a survey. Electron microscopy of the lesion tissues revealed cytopathic effects similar to those caused by dichorhaviruses, which was not identified (1).

Ref.: (1) Rodrigues, J.C.V. et al., Trop.Plant Pathol. 33: 12. 2008.

Polerovirus 


\section{Potato leafroll virus- PLRV}

Natural infection of B. pilosa by PLRV was reported in the state of Minas Gerais, without references to the symptoms (1).

Ref.: (1) Oliveira, C.D. et al. Fitopatol.bras. 21: 427. 1996.

Potyvirus

Bidens mosaic virus (BiMV)

B. pilosa plants were found showing mosaic symptoms in the state of São Paulo. Symptoms were result of an infection by a new potyvirus species as indicated by biological and serological assays and electron microscopy, named BiMV (1). It causes similar symptoms of another potyvirus described in Florida, US (Bidens mottle virus- BiMoV) but these viruses are considered different species of potyvirus. BiMV may occasionally be found infecting cultivated plants and ornamentals. It is aphid-borne, and mechanically transmissible. It was also detected in Brasília, DF (3). Analysis of the nucleotide sequence of the coat protein gene of a BiMV isolated from pea suggests that BiMV may be an isolate of PVY (4). However, complementary genome analysis demonstrated that BiMV and PVY are distinct viruses (5).

Ref.: (1) Kitajima, E.W. et al. Bragantia 20: 503. 1961; (2) Kuhn, G.B. et al. Fitopatol.bras. 5: 39. 1980; (3) 7: 185. 1982; (4) Dutra, S.L. et al. Virus Rev.\& Res. 9: 252. 2004; (5) Sanches, M.M. et al. Arch.Virol. 159: 2181. 2014.

\section{Potato virus Y (PVY)}

PVY was found infecting naturally $B$. pilosa in the state of Minas Gerais, without reference to the symptom (1).

Ref.: (1) Oliveira, C.D. et al. Fitipatol.bras. 21: 427.1996.

Alphanecrovirus

Tobacco necrosis virus (TNV)

TNV was recovered from roots of asymptomatic $B$. pilosa growing in greenhouse of Instituto Agronomico, Campinas, SP (1).

Ref.: (1) Costa, A.S. \& Carvalho, A.M.B. Bragantia 19: CXLVII. 1960.

\section{*Blainvillea rhomoboidea Cass. Asteraceae}

Begomovirus

Blainvillea yellow spot virus (BIYSV)

Golden mosaic and stunting in plants of B. rhomboidea were observed in the state of São Paulo, and considered a whitefly transmitted virus (1). It was also observed in the state of Pernambuco (2). A begomovirus, tentatively identified as BIYSV was isolated in Coimbra, MG, possibly distinct from other known begomoviruses, and possibly similar to the causal agent of previous descriptions (3).

Ref.: (1) Costa, A.S. Summa Phytopathol. 4: 13. 1978; (2) Lima, G.S.A. et al. Virus Rev.\& Res. 6: 158. 2001 ; (3) Castillo Urquiza, G.P. et al. Arch.Virol. 153: 1985. 2008.

\section{*Boerhavia coccinea Mill. (Scarlet spiderling) Nyctaginaceae Orthotospovirus}

\section{Groundnut ringspot virus (GRSV)}

B. coccinea plants growing near groundnut fields in Campina Grande, $\mathrm{PB}$, were found showing vein clearing, mosaic and leaf deformation. Serological assays indicated that these plants were infected by GRSV, and may serve as its reservoir for the groundnut crop (1).

Ref.: (1) Andrade, G.P. et al. Fitopatol.bras. 24: 358. 1999.

*Bougainvillea glabra Choisy; B. spectabilis Willd. (Bouganvillea) Nyctaginaceae

Badnavirus

Bougainvillea chlorotic vein banding virus (BCVBV)

Badnavirus-like particles were found by electron microscopy in bougainvillea samples from Campinas, SP, showing mottling and chlorotic spots (1). PCR assays performed from total DNA extracts from these samples, amplified a fragment of $465 \mathrm{nt}$, using specific primers for badnaviruses. Sequence analysis revealed that this badna virus from bougainvillea represented a new species and named BsCVB (2,3). A similar virus was detected in bougainvillea from the campus of ESALQ/USP in Piracicaba, SP (4) which was transmitted by the mealybug Planococcus citri (5). Sequence comparison of isolates from the state of São Paulo indicated that they differ from those collected in Andradas and Uberlândia, state of Minas Gerais and Brasília, DF (6). There are reports of the presence of BsCVB in the region of Seropédica, RJ and Ourinhos, SP (7).

Ref.: (1) Chagas, C.M. et al. Virus Rev. Res. 6: 153. 2001; (2) Alexandre, M.A.V. et al. Fitopatol.bras. 29 (supl.): S 150. 2004. (3) Rivas, E.B. et al. J. Gen.Plant Pathol 71: 438. 2005; (4) Yamashita, S. et al. Summa Phytopathol. 30: 68. 2004; (5) Kuniyuki, H. et al. Summa Phytopathol. 32 (supl.): S20. 2006; (6) Alexandre et al. Summa Phytopathol 38 (supl.) CDRom 2012; (7) Brioso, P.S.T. Virus Rev.\&Res. 17 (supl.). 346. 2012.

\section{*Bouvardia sp. (Bouvardia) Rubiaceae \\ Orthotospovirus \\ Chrysanthemum stem necrosis virus (CSNV) \\ Tomato chlorotic spot virus (TCSV) \\ Tomato spotted wilt virus (TSWV)}

Chlorotic mosaic symptoms were observed on the leaves of bouvardia in São Paulo, SP. Following studies by biological and serological assays and electron microscopy revealed that these plants were co-infected by the Orthotospoviruses TSWV e CSNV (1). In another sample with mild mosaic, also from São Paulo, infection by TCSV was confirmed (2).

Ref.: (1) Seabra, P.V. et al. Virus Rev. Res. 5: 197. 2000.; (2) Rivas, E.B. et al. Virus Rev.\& Res. 7: 22. 2002

\section{*Brachiaria sp. (Signalgrass) Poaceae Waikavirus \\ Maize chlorotic dwarf virus (MCDV)}

Mosaic symptoms were observed in signalgrass plants in an experimental plot at Embrapa Gado de Corte, Campo Grande, MS. Molecular assays detected MCDV associated with these symptoms (1).

Ref.: (1) Silva, K.N. et al. Virus Rev \& Res.20 (supl.): 211.2015. Potyvirus

\section{Johnson grass mosaic virus (JGMV)}

Samples with suspected viral infection, collected during surveys made in the Germplasm Bank of Embrapa Gado de Corte, Campo Grande, MS, submitted to RT-PCR assays, revealed to be infected by JGMV (1).

Ref.: (1) Schuch, H.C. et al. Virus Rev. \& Res. 21: 135. 2016.

\section{*Brassica carinata A.Br. (Abyssinian cabbage) Brassicaceae Potyvirus \\ Turnip mosaic virus (TuMV)}

Some Abyssinian cabbage under experiment for its introduction and adaptation in the Universidade Federal de Uberlândia, MG, considering its high content of vitamin A, appeared with mosaic symptoms. Biological assays and electron microscopy indicated that the symptoms were caused by infection with an isolate of TuMV (1). Ref.: (1) Rodrigues, F.A. et al. Fitopatol. Bras. 20: 338. 1995

\footnotetext{
*Brassica oleracea L. var. botrytis L. (Cauliflower); var. italica Plenck (Broccoli); var. gemmifera DC (Cole); var. pekinensis (Chinese cabbage); B. rapa L. (Turnip)

Brassicaceae

Carlavirus
} 


\section{Cole latent virus (CoLV)}

CoLV causes latent infection in many cultivated brassicas. Its first report was made on infected cole plants in the state of São Paulo, and detection was made by electron microscopy which showed the presence of elongated and flexuous particles $13 \mathrm{~nm}$ x $650 \mathrm{~nm}(1,2)$. Afterwards, CoLV has been detected in the states of Minas Gerais (2) and Federal District $(3,4)$. The inclusion of CoLV in the genus Carlavirus was confirmed by genome sequencing (4). Two Brazilian isolates of CoLV had their genome entirely sequenced (5).

Ref.: (1) Kitajima, E.W. et al. Bragantia 29:181. 1970; (2) Costa, A.S. et al. Rev.Oleric. 12: 82.1972; (3) Costa, C.L. et al. Fitopatologia 9: 49. 1974; (4) Mello, S.C.M. et al. Fitopatol.bras. 12: 352. 1987; (4) Belintani, P. et al. J. Phytopathology 150: 330. 2002; (5) Oliveira, AM. et al. Res.29 Cong.Bras.Virol. 2018.

\section{Potyvirus}

\section{Turnip mosaic virus (TuMV)}

Initial reports of TuMV infecting brassicas in Brazil were made on cabbage sampled in the state of São Paulo and in chinese cabbage, from Viçosa, MG, and afterward, in several brassicas in the states of Paraná and Federal District (1-5). Type I and II of TuMV were identified in the state of São Paulo (6). TuMV-infected chinese cabbage plants were found in Divinolândia and S.José R.Pardo, SP (7).

Ref.: (1) Silberschmidt, K. \& Roston, E. Cien.Cult. 5: 211. 1953; (2) Tokeshi, H. et al. Rev.Olericult. 3: 175. 1963; (3) Costa, A.S. et al. Rev.Oleric. 12: 82. 1972; (4) Lima, M.L.R.Z.C. et al. Rev.Setor Cien. Agr.,UFPR 2: 12.1980; (5) de Ávila, A.C. et al. Fitopatol.bras. 5:311. 1980; (6) Colariccio, A. et al. Summa Phytopathol. 25: 35. 1999; (7) Eiras, M. et al. Trop. Plant Pathol. 40 (supl.) CD Rom Res. 445.1. 2015

\section{Alphanecrovirus}

\section{Tobacco necrosis virus (TNV)}

TNV was recovered from asymptomatic cole, kept under greenhouse conditions, in the Instituto Agronomico, Campinas, SP (1).

Ref.: Costa, A.S. \& Carvalho, A.M.B. Bragantia 19: CXLVII. 1960. 2018.

Caulimovirus

\section{Cauliflower mosaic virus (CaMV)}

This isometric, aphid-borne DNA virus was first described in Brazil associated with symptoms of vein banding on cole leaves (1). Report of CaMV infecting several cultivated brassicas were made in 1963, but based only on symptoms, without further experimental identification (2). CaMV has been identified infecting several brassicas in the states of Paraná (4), Distrito Federal (5) and Espirito Santo (6). CaMV was also found infecting and causing mosaic in the ornamental Matthiola incana (hoary stock) in the state Rio Grande do Sul (3). An isolate of CaMV recovered from cauliflower in Venda Nova, ES, was characterized molecularly (7). Transmission by aphids (Myzus persicae and Brevicoryne brassicae) has been demonstrated (8). CaMV was found infecting chinese cabbage ( $B$. rapa) in Santo Antonio do Pinhal, SP (9).

Ref.: ( (1) Kitajima, E.W. et al. Bragantia 24: 219. 1965; 2) Tokeshi, H. et al. Rev.Olericultura 3: 175; 1963; (3) Siqueira, O. \& Dionelo, S.B. Fitopatologia (Lima): 8: 19. 1973; (4) Lima, M.L.R.Z.C. et al. Rev.Setor Cien.Agr., UFPR, 2: 12. 1980; (5) Cupertino, F.P. et al. Fitopatol.bras. 11:394. 1986; (6) Costa, H. et al. Fitopatol.bras. 16: XXVIII. 1991; (7) Zerbini, F.M. et al. Fitopatol.bras. 17:326. 1992; (8) Ambrozibivus, L.P. Fitopatol.Bras.22: 330. 199; (9) Oliveira, M.J. et al. Res.20, $40^{\circ}$ Cong.Paul.Fitop., 2017.

\author{
*Brassica napus L. (Canola) Brassicaceae \\ Cucumovirus \\ Cucumber mosaico virus (CMV) \\ Potyvirus
}

\section{Turnip mosaic virus (TuMV) \\ Caulimovirus \\ Cauliflower mosaic virus (CaMV)}

These three viruses (CMV, TuMV e CaMV) were found naturally infecting canola plants with mosaic symptoms in the state of Paraná (1).

Ref.: (1) Barbosa, C.J. et al. Fitopatol. Bras. 20: 286. 1995;

\section{*Brugmansia suaveolens (Willd.) Bercht. \& J. Presl. (White angel trumpet) Solanaceae}

Potyvirus

Brugmansia suaveolens mottle virus (BsMoV)

Some white angel trumpet plants from the germplasm collection of the Dept. Medicinal Plants of the Instituto Agronomico, Campinas, SP, were found showing mottling symptoms on their leaves. Further assays demonstrated that these plants were infected by a mechanical and aphid transmissible potyvirus, identified preliminarily as a possible isolate of PVY (1). Its genome was sequenced and revealed to represent a new species of potyvirus, which was named BsMoV (2). An isolate of this virus was found naturally infecting white angel trumpet plants at Parque do Papa, Curitiba, PR, causing mottling (3). Ref.: (1) Habe, M.H. et al. Fitopatol.bras. 18: 286. 1993; (2) Lucinda, N. et al. Arch.Virol. 153: 1971. 2008; (3) Souza, T.A. et al. Virus Rev. \& Res. 20:138-139. 2016.

\section{*Brunfelsia uniflora D .Don. (Yesterday-Today-Tomorrow) Solanaceae \\ Cilevirus \\ Cilevirus unidentified}

Green spots and ringspots were observed on senescent leaves of $B$. uniflora in a residential garden in Águas de S. Pedro, SP, associated with infestion by tenuipalpid mites Brevipalpus.. Electron microscopy of the tissues from the lesions revealed cytopathic effects characterist of those caused by Cilevirus. The causal virus, however, remains unidentified (1). Transmission of these symptoms by B. phoenicis s.l. was confirmed (2).

Ref.: (1) Nogueira, N.L. et al. Summa Phytopathol. 29: 278. 2003; (2) Ferreira, P.T.O. et al. Fitopatol.bras. 28: S250. 2003.

\section{C}

*Cactus bahiensis Rose \& Russell; Cereus triangularis Haw; C. hexagonus (L.) Miller; C. triangularis Haw; Hylocereus undatus (Haworth) Button \& Rose; Nopalea cochenillifera (L.) Salm. Dick.; Mamillaria sp.; Opuntia vulgaris Miller; O. leucotricha De Candolle; O. tuna Mill., Echinocereus sp.; Lobivia sp.; Pereskia aculeata (L.) Kaarsten; P. bleo (HBK) De Candolle (Cactus) Cactaceae

Potexvirus

Cactus virus $X(\mathrm{CVX}$

Opuntia virus $X(\mathrm{OpVX})$

Schlumbergera virus $X(S c h V X)$

Zygocactus virus $X$ (ZyVX)

Asymptomatic infection by CVX was observed in many assayed cactus species from the states of São Paulo and Federal District. Mechanical transmission assays resulted in the infection of test plants as Gomphrena globosa, Chenopodium amaranticolor and C. quinoa. Serology with specific anti-CVX serum and electron microscopy which detected typical potexvirus-like particles in extracts and in infected cells confirmed the presence of CVX in these plants. A novel protocol for purification managed to get purified CVX and a specific antiserum was produced (1). Several other cactus potexviruses (CVX, OpVX e SchVX) were found in Hylocereus undatus showing chlorotic 
and necrotic spots and mosaic, collected in São Paulo, SP (2). These viruses were identified by molecular assays $(3,4)$. Isolates of SchVX, CVX, ZyVX were found infecting Opuntia cochenillifera (Cochineal cactus) in the state of Pernambuco (5). Among these viruses, the Brazilian isolate of SchVX had its genome sequenced (6).

Ref.: (1) Aragão, F.J.L. et al. Fitopatol.bras. 18: 112. 1993. (2) Tozetto, A.R.P. et al. Arq.Inst.Biol 72 (supl): 77. 2005; (3) Duarte, L.M.L. et al. Fitopatol.bras. 27(supl.): S203. 2002. (4) Duarte, L.M.L. et al. Journal Plant Pathol. 90: 545. 2008; (5) Lamas, N.S. et al. Virus Rev. \&.Res. 19 (supl): 217. 2014; (6) Sanches, M.M. et al. Genome Announcements, v. 3, p. e00133-15, 2015.

\section{*Caesalpinia echinata Lam. (Brazil wood) Fabaceae}

Orthotospovirus

Groundnut ringspot virus (GRSV)

Tomato chlorotic spot iírus (TCSV)

Tomato spotted wilt virus (TSWV)

Cucumovirus

Cucumber mosaic virus (CMV)

Potyvirus

Pepper yellow mosaic virus (PepYMV)

Potato virus Y (PVY)

Watermelon mosaic virus (WMV)

Zucchini yellow mosaic vrus (ZYMV)

Tobamovirus

Pepper mild mottle virus (PMMoV)

Tomato mosaic virus (ToMV)

During a survey to detect viruses in woody plants made in a nursery of Distrito Federal, the above-listed viruses were detected in Brazil by biological and/or serological assyas. There is no reference about symptoms nor further confirmation of the identity of these viruses by molecular means $(1,2)$.

Ref.: (1) Batista, J.G. et al. Virus Review \& Res. 21: 122. 2016; (2) Santos, M.F.B. et al. Trop.Plant Pathol. 41 (supl.) 2016.

\section{*Caladium bicolor Vent. (Calladiums) Araceae}

Potexvirus

Caladium virus X (CalVX)

Potyvirus

Dasheen mosaic virus (DsMV)

Co-infection of calladiums by DsMV and a potexvirus resulting in chlorotic necrotic spots on the leaves were observed on plants collected in São Paulo, SP (1). The potexvirus was found to be a new species based on biological, serological and molecular assays. A fragment of $740 \mathrm{nt}$ amplified by RT-PCR had less than $75 \%$ identity with those of other potexvirus, indicating a new species, which was named ClVX (2). Ultrastructural observations confirmed the presence of cylindrical inclusions, typical of potyviruses, as well great fibrous masses, characteristic of potexviruses. These inclusions could be noticed also by light microscopy (3).

Ref.: (1) Rivas, E.B. et al. Fitopatol.bras. 29:150-151. 2004 (2) Rivas, E.B. et al. Plant Pathol. 87:109-114. 2005 (3) Rivas, E.B. et al. Arq. Inst. Biol. 7: 457.2004.

\section{*Calibrachoa sp. (Million bells) Solanaceae}

Tobamovirus

Tobamovirus unidentified

An unidentified tobamovirus was detected in Million Bells in São Paulo, SP. No description of symptoms was made (1).

Ref (1) Alexandre, M.A.V. et al. Rev.Bras.Hort.Ornam. 16: 95.2010.

*Callistephus chinensis L. (Aster) Asteraceae

Cytorhabdovirus

\section{Cytorhabdovirus unidentified}

Aster plants with systemic chlorosis and leaf distortion were observed in an experimental field of the Instituto Agronomico, Campinas, SP. Electron microscopy revealed the presence of cytorhabdovirus in the tissue of these plants, but it could not be identified (1).

Ref.: (1) Kitajima, E.W. \& Costa, A.S. Fitopatol.bras. 4: 55. 1979

Orthotospovirus

Chrysanthemum stem necrosis virus (CSNV)

Groundnut ringspot virus (GRSV)

Tomato chlorotic spot virus (TCSV)

Co-infection of aster plants by these three Orthotospoviruses, resulting in symptoms of mosaic, bronzed and deformed leaves and stem necrosis was noticed in a commercial plantation in Holambra, $\operatorname{SP}(1,2)$.

Ref.: (1) Alexandre, M.A.V. et al. Summa Phytopathol. 25: 353. 1999; (2) Rivas, E.B. et al. Res. $13^{\circ}$ Cong. Bras. Floricultura e Plantas Ornamentais. 138. 2001

\section{*Calopogonium mucunoides Desvaux (Calopo) Fabaceae \\ Comovirus \\ Cowpea severe mosaic virus (CPSMV)}

Calopo plants with mosaic symptoms were found in the Federal District associated with infection by serotype I of CPSMV (1).

Ref.: (1) Lin, M.T. \& Anjos, J.R.N. Plant Dis. 66: 67. 1982.

Cucumovirus

Cucumber mosaic virus (CMV)

Mosaic symptoms were observed on Calopo plant in the state of Paraná. The causal agent of the disease was identified as an isolate of CMV (1)

Ref.: (1) Almeida, A.M.R. et al. Virus Rev. \& Res. 2: 194. 1997.

Begomovirus

Macroptilium yellow spot virus (MaYSV)

Natural infection of calopo by the begomovirus MaYSV was observed in the state of Alagoas (1).

Ref.: (1) Silva, J.C.V. et al. Plant Pathol. 61: 457. 2012.

\section{*Campanula medium L. (Bell flower) Campanulaceae Orthotospovirus \\ Tomato spotted wilt virus (TSWV)}

Mosaic, necrosis and ringspots on the leaves and flowers of Bell flower were observed in a commercial plantation in Atibaia, SP. Further assays identified the causal agent as an isolate of TSWV (1). Ref.:(1) Gioria, R. et al. Summa Phytopathol. 36: 176. 2010.

\section{*Campomanesia adamantium (Cambess) O. Berg. Myrtaceae Begomovirus \\ Tomato severe rugose virus (ToSRV) \\ C. adamantium plants growing together with jack bean (Canavalia} ensiformis) in the state of Mato Grosso do Sul were found showing vein clearing, chlorotic spots and leaf deformation. RT-PCR assays indicated that they were infected by ToSRV (1).

Ref.: (1) Stangarlin, O.S. et al. Summa Phytopathol. 40 (supl.) CD Rom. 2014.

\section{*Canavalia ensiformes D.C. (Jack bean) Fabaceae \\ Comovirus}

Cowpea severe mosaic virus (CPSMV)

Jack bean plants exhiting severe mosaic and bubbly leaves were found in the state of Ceará. The causal agent was identified as CPSMV (1).

Ref.: (1) Lima, J.A.A. \& Souza, C.A.V. Fitopatol.bras. 5: 417. 1980. Potyvirus 


\section{Cowpea aphid-borne mosaic virus (CABMV)}

Mosaic symptoms on jack bean leaves were observed in the state of São Paulo. The unidentified viral agent was mechanically transmitted to Jack bean, soybean, pea and sweet pea, but not to cowpea and common bean (1). This condition probably was similar to a later report made in Jack bean samples from the state of Pernambuco tentatively attributed to a potyvirus, as well as to a similar case found in the Federal District, which was aphid-borne $(2,3)$. Similar case was registered in the state of Rio de Janeiro (2). The virus was purified and a specific antiserum was produced, showing serological relationship with several legume potyviruses as CABMV, BCMV, SMV (3). Although tentatively named Canavalia mosaic virus- CanMV (4.5), it is probably an isolate of the CABMV.

Ref.: (1) Silberschmidt, K. \& Nobrega, N.R. O Biológico 8: 129. 1943; (2) Costa, C.L. et al. Fitopatol. Bras. 14: 115. 1989; (3) Santos, O.R. et al. Fitopatol.bras. 16: XXVII. 1991; (4) Costa, C.L. et al. Fitopatol. Bras.9: 400. 1984; (5) Santos, O.R. Diss.Mest.,UnB, 78 p. 1991.

Begomovirus

\section{Tomato severe rugose virus (ToSRV)}

A case of natural infection of Jack bean by ToSRV was found in the state of Mato Grosso do Sul (1).

Ref.: (1) Stangarlin, O.S. et al. Summa Phytopath. 40 (supl.) CDRom. 2014.

\section{*Canavalia rosea (Sw.) DC (=C. maritima Thouars) (Beach bean) Fabaceae \\ Potyvirus \\ Cowpea aphid-borne mosaic virus (CABMV)}

Beach bean commonly grows in coastal regions of Brazil. Plants showing mosaic and chlorotic spots on their leaves wee found in several beaches near Caraguatatuba, SP. Subsequent assays revealed that these plants were infected by a potyvirus, with similar characteristics of Canavalia maritima mosaic virus (CanMMV) described in Puerto Rico (1). More detailed studies including genome sequencing indicated that this potyvirus infecting beach bean in Brazil is an isolate of the CABMV (2).

Ref.: (1) Kitajima, E.W. et al.Virus Rev\&Res9: 252. 2004; (2) Madureira, P.M. et al. Arch. Virol. 153: 743. 2008.

\section{*Canavalia sp. Fabaceae}

Begomovirus

\section{Macroptilium yellow spot virus (MaYSV)}

MaYSV was found infecting an unidentified species of Canavalia in the state of Alagos (1).

Ref..: (1) Silva, J.C.V. et al. Plant Pathol. 61: 457. 2012.

\section{*Canna paniculata Ruiz \& Pav. Cannaceae}

Potyvirus

Canna yellow streak virus (CaYSV)

C. paniculata plants showing yellow streaks on their leaves were found in a public park in Piracicaba, SP. Mechanical transmission assays only manage to infect the same species. CI region amplified by RT-PCR revealed identity with CaYSV, described in the UK (1). Ref.: (1) Alexandre, M.A.V. et al. Aust.Plant Dis.Notes 12: 38. 2017

\section{*Capsicum annuum L. (Pepper) Solanaceae} Orthotospovirus

Groundnut ringspot virus (GRSV)

Tomato chlorotic spot virus (TCSV)

Tomato spotted wilt virus (TSWV)

Orthotospovirus unidentified

Unidentified Orthotospovirus was found infecting pepper with mosaic and leaf deformation symptoms in Manaus, AM (1) and in the Federal District (2). Diversity of Orthotospoviruses infecting pepper was noticed in the state of São Paulo, as judged by responses of inoculated 'Manteiga' bean, which reacted either with chlorotic or necrotic lesions (3). Natural infection of pepper by TSWV was observed in the Federal District (4), while GRSV was found in pepper in Janaúba, MG (5). In the state of São Paulo, pepper plants were infected by TCSV (6) and GRSV (8). In a survey in pepper fields in the valley of São Francisco, in the state of Pernambuco, a high incidence of GRSV was noticed (7).

Ref.: (1) Kitajima, E.W. et al. Acta Amazonica 9: 633. 1979; (2) Cupertino, F.P. et al. Fitopatol. Bras. 5: 395. 1980; (3) Costa, A.S. \& Gaspar, J.O. Summa Phytopathol. 7: 5. 1981; (4) Boiteux, L.S. et al. Capsicum and Eggplant Newsletter 12: 75. 1993; (5) Fitopatol. Bras. 19: 285. 1994; (6) Colariccio, A. et al. Fitopatol.bras. 20: 347. 1995; (7) de Avila, A.C. et al. Fitopatol. Bras. 21: 503. 1996; (8) Colariccio, A. et al. Summa Phytopathol. 27: 323. 2001.

\section{Cucumovirus}

\section{Cucumber mosaic virus (CMV)}

CMV infecting pepper was first registered in samples from Embú, SP, in plants showing mosaic symptoms (1). CMV satellite virus was detected in pepper samples from the state of Minas Gerais (2). Pepper samples from several regions of the state of São Paulo were infected by subgroup I CMV (3).

Ref.: (1) Mallozzi, P. Rev.Soc.Bras.Fitopat. 4: 101. 1971; (2) Boari, A.J. et al. Fitopatol.bras. 25: 143. 2000; (3) Frangioni, D.S.S. et al. Summa Phytopathol. 29: 19. 2003

Crinivirus

\section{Tomato chlorosis virus ToCV}

ToCV was detected in pepper plants showing interveinal chlorosis and epinasty sampled in S. Miguel Arcanjo, SP (1).

Ref. (1) Barbosa, J.C. et al. Plant Dis. 94: 374. 2010.

\section{Polerovirus}

\section{Potato leafroll virus (PLRV)}

An isolate of PLRV was recovered from pepper plants showing generalized chlorosis. It was considered that such plants may serve as the source of PLRV for tomato crops (1).

Ref.: (1) Costa, A.S. \& Carvalho, A.M.B. Coopercotia fev.62,p.34.

Potyvirus

\section{Pepper yellow mosaic virus (PepYMV)}

Two isolates of potyvirus recovered from pepper showing mosaic symptoms in a commercial pepper plantation in Bragança Paulista, SP and Brasília, DF were identified, based on biological, serological and molecular assays, as a new species and designated PepYMV. This virus was able to infect pepper varieties resistant to PVY (1). Subsequently, the virus was shown to be widespread in Brazil, being registered in the states of AM, PE, BA, MG, ES and SP (2). Its genome has been entirely sequenced (3).

Ref.: (1) Inoue-Nagata, A.K. et al. Arch. Virol. 147: 840. 2002; (2) Virus Rev. \& Res. 8: 186. 2003; (3) Lucinda, N et al. Arch.Virol. 157.: 1397.2012.

\section{Potato virus Y ( PVY)}

Symptoms of significant plant size reduction, vein banding and bubble type of mosaic and curling on leaves and malformed fruits of pepper were reported in the state of São Paulo, and the causal agent was identified as an isolate of PVY (1). Resistant varieties were obtained by a breeding program (2). PVY-caused disease on peppers was also registered in the states of Rio de Janeiro $(3,4)$, Minas Gerais, Federal District and Espirito Santo (5).

Ref.: (1) Costa, A.S. \& Alves, S. Bragantia 10: 95. 1950; (2) Nagai, H. Braglantia 27: 311. 1968; (3) Robbs, C.F. \& Viegas, E.C. Guia de Controle às pragas e doenças das Cult.Econo. do Estado, Sec.Agric. Abast., RJ. 84p. 1978; (4) Brioso, P.S.T. et al. Fitopatol. Bras. 18: 274. 
1993; (5) Truta, A.A.C. Virus Rev.\& Res. 5: 193. 2000.

Tobamovirus

Pepper mild mottle virus (PMMoV)

Tobacco mosaic virus (TMV)

Tomato mosaic virus (ToMV)

These tobamoviruses were detected in pepper samples with mosaic symptoms, from Salto and Bragança Paulista, SP. Identification of these viruses were made by biological assays $(1,2)$ and by RT-PCR (3).

Ref.: (1) Kobori, R.F. et al. Fitopatol. Bras. 26: 516. 2001; (2) Cezar, M.A. et al. Summa Phytopathol. 29: 359. 2003.(3) Cezar, M.A. et al. Summa Phytopathol. 32 (supl): S37.2006.

Tobravirus

Pepper ringspot virus (PepRSV)

PepRSV was first identified in pepper plants showing chlorotic lines and rings on their leaves in São Carlos, SP. The viral nature of the disease was confirmed by biological assays and electron microscopy and named vein banding $(1,2)$ or ringspot $(3)$ virus. Further works indicated likeliness with Tobacco rattle tobravirus, but considered distinct (6) and officially named PepRSV. A cytopathological peculiarity of PepRSV is that its virions are commonly arranged perpendicularly onto mitochondrial surface (5). PepRSV has a wide experimental host range and is seed-borne (3) possibly associated with infection of polen grains (4). Soil transmission of the virus has been demonstrated in association to nematodes of the genus Trichodorus and/or Paratrichodorus (7). The virus found in pepper plants in the state of Paraná (8). Isolates of PepRSv were found infecting tomato in Luziania, GO, and infectious clones were produced (9).

Ref.: (1) Silberschmidt, K. Phytopathol.Zeit. 46: 209. 1962; (2) Silberschmidt, K. Phytopathol.Zeit. 46: 209. 1962; (3) Costa, A.S. \& Kitajima, E.W. Rev Soc.Bras. Fitopatol. 2: 25. 1968; (4) Camargo, I.J.B. et al. Phytopathol.Zeit. 64: 282. 1969; (5) Kitajima, E.W. \& Costa, A.S. J. Gen.Virol. 4: 177. 1969; (6) Kitajima, E.W. et al. Bragantia 28: 1. 1969; (7) Salomão, T.A. et al. Arq. Inst. Biol.. 42: 133. 1975; (8) Lima, M.L.R.Z.C. et al. Rev.Setor Cien.Agr.UFPR 5:91. 1983; (9) Tavares, M.L. MS Diss., UnB, 2017.

Begomovirus

\section{Tomato golden vein virus (ToGVV)}

Tomato severe rugose virus (ToSRV)

Pepper plants showing leaf curl from various regions in the state of São Paulo were found to be infected by ToGVY $(1)$ and $\operatorname{ToSRV}(1,2)$. ToRSV was also found infecting pepper in the state of Minas Gerais (3) and in Campo Grande, MS (4).

Ref: (1) Nozaki, D.N. et al. Fitopatol.Bras.31:321.2006; (2) Paula, D.F. et al. Virus Rev.\& Res. 11(supl): 189. 2006. (3) Nozaki, D.N. et al. Virus Rev\&Res 15(supl) 114.2010; (4) Stangarlin O.S. et al. Trop. Plant Pathol. 39 (supl.) CDRom 204.

\section{Tomato rugose mosaic virus (ToRMV)}

Greenhouse-grown pepper plants were found with leaf curl and stuting symptoms in Marília, SP. ToRMV was found in these plants by molecular technique but there is no biological evidence that this virus is the causal agent of the disease (1).

Ref.: (1) Cotrim, M.A.A. et al. Summa Phytopathol. 30: 100. 2004.

Curtovirus unclassified

\section{Brazilian tomato curly top virus (BrCTV)}

Leaf yellowing, short internodes and reduced size, flattened fruits symptoms were observed in the state of São Paulo. The causal agent was identified as the same virus causing curly top in tomato (BrCTV), transmitted by leafhopper. Bristly starbur (Acanthospermum hispidum) may serve as virus source (1). Similar condition was found in Manaus, AM (2).

Ref.: (1) Costa, A.S. \& Nagai, H. Rev.Oleric. 6: 83. 1966; (2) Kitajima, E.W. et al. Acta Amazonica 9: 633. 1979.

*Capsicum baccatum L (Chili pepper), C. baccatum var. praetermissum (Pimenteira Cumari) Solanaceae

\section{Orthotospovirus}

Groundnut ringspot virus(GRSV)

Tomato chlorotic spot virus (TCSV)

Tomato spotted wilt virus (TSWV)

Potyvirus

Pepper yellow mosaic virus (PepYMV)

Potato virus Y (PVY)

Tobamovirus

\section{Pepper mild mottle virus (PMMoV)}

These viruses were detected during surveys made in the germplasm collection of C. baccatum of Embrapa Hortaliças, Brasília, DF (1-5). Ref.: (1) Boiteux, L.S. et al. Euphytica 67: 89. 1993; (2) Nagata, T. et al. Fitopatol.bras. 18: 425. 1993;(3) Lima, M.F. et al. Acta Hort. (ISHS) 917: 285. 2010; (4) Lima, M.F. et al Trop. Plt. Pathol. 35(supl) S175. 2010; (5) Lima, M.F. et. J. Plant Pathol. 92:122. 2010.

Begomovirus

Tomato rugose mosaic virus (ToRMV)

Samples of $C$. baccatum with mosaic and foliar deformation symptoms were collected in Petrolina de Goiás, GO. PCR assays detected ToRMV in these plants but its role as the etiological agent of the disease could not be demonstrated (1), which was later made using biobalistic methods, in which $C$. annuum plants revealed to be also susceptible to ToMRV (2).

Ref.: (1) Ferreira, G.B. et al. Fitopatol.bras. 29: S202. 2004; (2) Bezerra-Agasie, I.C. et al. Plant Dis. 90: 114. 2006.

\section{*Capsicum chinense Jacq. (Cumari pepper) Solanaceae Orthotospovirus \\ Tomato spotted wilt virus (TSWV)}

Leaf local lesions followed by systemic chlorotic ringspots, mosaic and stunting were observed in $C$. chinense cultivated under greenhouse conditions $(1,2)$ and under field conditions in Brasilia, DF (3). Resistance to TSWV of $C$. chinense was broken by infection with GRSV and TCSV isolates (4).

Ref.: (1)Nagata T. et al. Fitopatol. Bras. 18: 425. 1993. (2) Boiteux, L.S. \& Nagata, T. Plant Dis 77: 210. 1993; (3) Boiteux, L.S. et al. Euphytica 67: 89. 1993.

Potyvirus

Pepper yellow mosaic virus (PepYMV)

C. chinensis plants exhibiting mosaic and foliar deformation, collected at Parauapebas and Santarém, PA. were found to be infected by PepYMV as demonstrated by serological and molecular assays, complemented by electron microcospy (1).

Ref.:(1) Carvalho, T.P. et al. Trop.Plt.Pathol. 40 (supl): 44.1. 2015.

Begomovirus

Sida micrantha mosaic virus (SimMV) (1).

SmMV was detected infecting $C$. chinense in Campo Florido, MG

Ref.: (1) Teixeira, E.C. et al. Trop.Plt Pathol. 33(supl): S289. 2008.

*Capsicum frutescens L. (Chili pepper) Solanaceae

Orthotospovirus 


\section{Tomato spotted wilt virus (TSWV)}

Chlorotic rings were observed on the leaves of many accessions of $C$. frutescens in the germplasm collection of Embrapa Hortaliças, Brasília, DF. Causal agent was identified as TSWV (1). The same virus was found in samples from different genotypes being assayed under field conditions and showing chlorotic rings and reduction of leaf size as well as stunting $(2,3)$.

(1) Boiteux, L.S. et al. Euphytica 67: 89. 1993; (2) Lima, M.F. et al. Hort.Bras. 28: S1187. 2010; (3) Lima, M.F. et al. Acta Hort. (ISHS) 917: 285. 2010

\section{Cucumovirus}

\section{Cucumber mosaic virus (CMV)}

C. frutescens plants exhibiting mosaic and leaf deformation were observed in the state of Pará. Presence of isometric particles in leaf extracts and RT-PCR assays using specific primers pointed to CMV as the causal agent of the disease (1).

Ref.: (1) Carvalho, T.P. et al. Trop.Plt.Pathol. 38 (supl.) 286-1.2013. Potyvirus

\section{Pepper mottle virus (PeMV)}

PeMV was detected infecting $C$. frutescens, based upon biological and serological assays (1).

Ref.: (1) Torres Fo..J. et al. Virus Rev.\& Res. 5: 197. 2000.

\section{Potato virus Y (PVY)}

Biological and immunoassays identified PVY infecting $C$. frutescens in the state of Minas Gerais (1). This virus was also detected by serological means, in several $C$. frutescens genotypes collected in the state of Goiás and Distrito Federal $(2,3)$.

Ref.: (1) Truta, A.A.C. et al. Virus Rev. \& Res. 5: 193. 2000. (2) Lima, M.F. et al. Hort. Bras. 28: S1187. 2010; (3) Lima, M.F. et al. Acta Hort. (ISHS) 917: 285. 2010.

Tobamovirus

\section{Pepper mild mottle virus (PMMoV)}

PMMoV was detected in C. frutescens seeds coming from the state of São Paulo, based on biological, serological and molecular assays and electron microscopy (1). The same virus was found in plants of different genotypes of chili pepper in the states of Goias and Distrito Federal by serology (2-4).

Ref.: (1) Eiras, M. et al. Summa Phytopathol. 29: 60. 2003. (2) Lima, M.F. et al. Hort.Bras., 28: S1187-S1194. 2010. (3) Lima, M.F. et al. Acta Hort. (ISHS) 917: 285-290. 2010. (4) Lima, M.F. et al. Acta Hort. (ISHS) 917: 285. 2010.

\section{* Cardiopetalum calophyllum Schltdl. Annonaceae Begomovirus \\ Begomovirus unidentified}

A systematic survey is being made on plants forming the Cerrado bioma in Central Brazil. During this survey, from several samples collected in the state of Goiás, only $C$. calophyllum revealed to be infected by an unidentified begomovirus, detected by PCR assay (1). Ref.: (1) Rocha, G.A. \& Dianese, E.C. Res.36, 50 Cong.Bras.Fitopat. 2017

\section{*Carica papaya L. (Papaya) Caricaceae Nucleorhabdovirus \\ Nuclerhabdovirus unidentified}

Solo papaya plants from the Humaitá colonization project near Rio Branco, AC were found showing severe mosaic, epinasty, leaf distortion and yellowing. Mechanical transmission of the disease was unsuccesful. Electron microscopy of infected tissues revealed the presence of a possible nucleorhabdovirus, suggesting a relation with the papaya apical necrosis, described in Venezuela, also associated with a rhabdovirus $(1,2)$.

Ref.: (1) Ritzinger, C.H.S.P. \& Kitajima, E.W. Fitopatol.bras. 12: 146.
1987; (2) Kitajima, E.W. et al. Fitopatol.bras. 16: 141. 1991.

Alfamovirus

\section{Alfalfa mosaic virus (AMV)}

AMV was found infecting field papaya causing mosaic symptoms, in Piracicaba, SP. Identification was based on mechanical transmission and molecular assays, and electron microscopy (1).

Ref. (1) Moreira, A.G. et al. J. Gen. Plt. Pathol . 76: 172. 2010.

Potyvirus

\section{Papaya ringspot virus type $\mathrm{P}$ (PRSV-P)}

PRSV-P is by and large, the most important pathogen for papaya plantations in Brazil, being present wherever papaya is cultivated. Bitancourt in 1935 (1) described a mosaic in papaya, but published images suggest that the symptoms probably resulted from mite infestation (2). PRSV-P causes a devastating disease characterized by symptoms of mosaic, leaf blistering and deformation, oily streaks in the stems and petioles and typical ringspots on the fruits. The condition is referred to as "mosaic" in Brazil. First official register of the virus was made in 1969 in Monte Alto, SP (3, 4). The virus is spread by aphids, though they do not form colonies in papaya plants. PRSV-P has been described in most states of Brazil (Northeast- Ceará, Rio Grande do Norte, Pernambuco, Bahia; Southeast- Espirito Santo, Minas Gerais; Center West- Goias, Distrito Federal) (5-9). There is no varietal resistance, and the control measure being used successfully is the systematic elimination ("rouguing") of infected plants. In the state of Espirito Santo the rouguing became compulsory by Law, and later in all papaya producing and exporting states, in 1994 and extended to 2009. Attempts to use mild strains for cross-protection failed, possible because of the irregular distribution of PRSV-P in the infected plant. Transgenic PRSV-P-resistant papaya plants were produced but they are still waiting for official permission to be used in field conditions (10). Coat protein gene of several Brazilian isolates of PRSV-P has been sequenced (11). In the state of Espirito Santo, where PRSV-P was controlled by continuous rouguing program, apparently a selection of a mild strain took place, which did not had a protecting role against severe isolates (12). Except for a single case reported in the state of Amazon (13), PRSV-P has not been observed in the Amazon basin.

Ref.: (1) Bitancourt, A.A. O Biológico 1: 41. 1935; (2) Costa, A.S. O Biologico 7: 248. 1941; (3) Costa, A.S. et al. O Agronomico 21: 38. 1969; (4) Rev.Soc.Bras.Fitopatol. 3: 55. 1969; (5) Lima, J.A.A. et al. Fitossanidade 1: 56. 1975; (6) Almeida, A.M.R. \& Carvalho, S.L.C. Fitopatol.bras. 3: 65. 1978; (7) Barbosa, F.R. \& Paguio, O.R. Fitopatol.bras. 7: 37. 1982; (8) Kitajima, E.W. et al. Fitopatol. Bras. 9:607. 1984; (9) 12: 106. 1987; (10) Nickel, O. et al. Fitopatol. Bras. 29: 305. 1995; (11) Souza Jr., M.T. \& Gonsalves, D. Fitopatol.bras. 24: 362. 1999; (12) Moreira, A.G. et al. Virus Rev.\& Res. 11 (supl): 48. 2006; (13) Brioso, P.S.T. et al. Trop.Plt. Pathol. 38: 196. 2013.

\section{Sobemovirus}

\section{Papaya lethal yellowing virus (PLYV)}

The first report of PLYV was made on papaya samples collected at Vertentes and Pombos, state of Pernambuco, with generalized yellowing on the leaves, which dropped later. Plant tips were chlorotic and deformed, following by wilting and death of the plant; fruits wilted, followed by intense latex exudation. The condition was called lethal yellowing and its viral etiology was confirmed by mechanical transmission assays, and the abundant presence of isometric particles, ca. $30 \mathrm{~nm}$ in diameter, in leaf extracts (1). Soon after, the disease was observed in the states of Bahia (2), Rio Grande do Norte (3), Ceará (6) and Paraíba (7). An isolate from the state of R.G. Norte was purified and a specific antiserum was produced (4) and revealed to be identical to the original isolate found in the state of Pernambuco (5). Genome sequence analysis indicated that PLYV would belong to the family Tombusviridae (8), possibly to the genus Sobemovirus (10-12). There are evidences for the soil transmission of PLYV (9). 
Ref.: (1) Loreto, T.J.G. et al. O Biológico 49: 275. 1983; (2) Vega, J. et al. Fitopatol.bras. 13: 147. 1988; (3) Kitajima, E.W. et al. Fitopatol. bras. 17: 282. 1992; (4) Oliveira, C.R.B. et al. Fitopatol.bras. 14: 114.1989; (5) Kitajima, E.W. et al. Fitopatol.bras. 17: 336. 1992; (6) Lima, J.A.A. et al. Fitopatol.bras. 19: 437. 1994; (7) Camarço, R.F.E.A. et al. Fitopatol. Bras. 21: 413. 1996; (8) Silva, A.M.R. et al. Fitopatol.bras. 22: 529. 1997; (9) Camarço, R.F.E.A. et al. Fitopatol. bras. 23: 453. 1998; (10) Silva, A.M.R. et al. Virus Rev.\& Res. 5: 196. 2000; (11) Amaral, P.P.R. et al. Virus Rev. \& Res. 7: 154. 2002; (12) Pereira,A.J. et al. Virus Rev.\& Res. 16 (supl.) CDRom. 2011. Alphanecrovirus

\section{Tobacco necrosis virus (TNV)}

TNV was recovered from asymptomatic papaya plants kept under greenhouse conditions at the Instituto Agronomico, Campinas, SP (1). Ref.: Costa, A.S. \& Carvalho, A.M.B. Bragantia 19: CXLVII. 1960.

Umbravirus

Papaya meleira virus 2 (PMeV2)

Totivirus unidentified

Papaya meleira virus (PMeV)

Spontaneous exudation of latex, of aqueous consistency from fruits, leaves and stems were first observed in commercial papaya plantations in Linhares, ES. Fruits become stained after exuding latex dries and also tasteless, worthless for the market. The condition was coined as "meleira" by the growers and hence the name of the virus Papaya meleira virus (PMeV). Epidemiological studies suggested viral etiology, and the causal agent was demonstrated to be transmissible through injection of latex from affected plants (1). The disease was associated with the presence of isometric particles, ca. $50 \mathrm{~nm}$ in diameter in látex extracts and in lacticifer cells and dsRNA, ca. 6 $\mathrm{x} 10^{6} \mathrm{Da}(2)$. The disease was found soon after in the states of Bahia (3), in the submedium São Francisco- state of Pernambuco (4), state of Ceará (6), and Jaíba, state of Minas Gerais (8). There is an unconfirmed case of transmission using whitefly extract (5). The virus was purified and showed to have a dsRNA genome with $12 \mathrm{kpb}$ (7). The use of NSG permitted to obtain the complete genome sequence of $\mathrm{PMeV}$, ca. $9000 \mathrm{nt}$, similar to members of mycoviruses of the family Totiviridae $(9,10)$. A second ssRNA virus $(4500 \mathrm{nt})$, referred to as PMeV-2, similar to the Papaya virus Q- PVQ, was described in papaya in Ecuador (genus Umbravirus), was also found associated to meleira, in Mexico, and also confirmed in Brazil (10).

Ref.: (1) Rodrigues, C.H. et al. Fitopatol. Bras. 14: 118. 1989; (2) Kitajima, E.W. et al. Fitopatol.bras. 18: 118. 1993; (3) Barbosa, C.J. et al. Fitopatol. Bras. 22: 331. 1997; (4) Lima, M.F. et al. Fitopatol.bras. 24; 365.1999; (5) Habibe, T.C. et al. Fitopatol.bras. 26: 526. 2001; (6) Lima, R.C.A. et al. Fitopatol.bras. 26: 522. 2000; (7) Maciel-Zambolin, E. et al. Plant Pathology 52:389. 2003; (8) Boari, A.J. et al. Fitopatol. bras. 29: S73. 2004. (9) Abreu E.F. et al. Arch. Virol. 160: 3143..2015; (10) Antunes, T.F.S. et al. Plos One 11, p. e0155240. 2016.

\section{*Caryocar brasiliense Camb. (Soari nut, pequi) Caryocaraceae Isometric virus unidentified}

Plants of $C$. bransiliense with mosaic, chlorotic spots and interveinal chlorosis on their leaves were observed in Brasília, DF. Mechanical inoculation resulted in local lesion in some legume assay plants tested, but pequi could not be infected. Isometric particles were noticed in leaf extracts examined by electron microscopy.

Ref.: (1) Costa, C.L. et al. Fitopatol.bras. 14: 115. 1989.

\section{*Cassia hoffmannseggii Mart ex Benth Fabaceae \\ Tymovirus}

Cassia yellow mosaic associated virus (CaYMaV)

A tymovirus, tentatively named $\mathrm{CaYMaV}$, was found causing bright yellow mosaic in C. hoffmanseggi, a wild legume common in the Northeastern Brazil, occasionally in co-infection with CABMV, in the state of Pernambuco. From the sequence of the coat protein, the closest tymovirus is Kennedya yellow mosaic virus.

Ref.: (1) Nicolini, C. et al. Virus Genes 42: 28. 2012.

Potyvirus

\section{Cowpea aphid-borne mosaic virus (CABMV)}

Mosaic bearing $C$. hoffmanseggi plants are common in several municipalities of the state of Pernambuco, and was found to be infected by CABMV. This isolate of CABMV causes local lesion in Chenopodium amaranticolor and is able to infect sesame when mechanically inoculated $(1,2)$. It is transmitted by aphids in nonpersistent, styletar way (2). Serology indicated that this isolate from $C$. hoffmanseggi is close to the subgroup of BCMV among potyvirus (3). Ref.: (1) Paguio, O.R. \& Kitajima, E.W. Fitopatol.bras. 6: 187. 1981; (2) Souto, E.R. \& Kitajima, E.W. Fitopatol.bras. 16: 256. 1991; (3) 17: 292. 1992.

\section{*Cassia macranthera DC, Cassia sylvestris Vell. Fabaceae Carlavirus \\ Cassia mild mosaic virus (CasMMoV)}

A mild mosaic on the leaves of C. sylvestris, noticed in Brasília, DF, was found to be caused by a carlavirus (1), which was also associated with a dieback of $C$. macranthera (2). Evidences that an aerial vector, probably aphids, is involved in the spread of the virus was obtained in the state of Paraná (3). This carlavirus, named CasMMoV, was also found in the state of São Paulo, causing pod necrosis (4).

Ref.: (1) Lin, M.T. et al. Plant Dis.Reptr. 63: 501. 1979; (2) Lin, M.T. 64: 587. 1980; (3) Lima No., V.C. et al. Fitopatol.bras. 16: LII. 1991; (4) Seabra, P.V. et al. Virus Rev. \& Res. 3: 143. 1998, 2001.

\section{Tymovirus}

Senna virus X (SeVX)

Potyvirus

Senna virus Y (SeVY)

An unidentified elongated virus was found in leaf extracts of C. macranthera with chlorotic spots on its leaves in Viçosa, MG. Sequence analysis of nucleic acid present in leaf extracts of symptomatic plants indicated the presence of at least two distinct viruses. A new potyvirus, named Senna virus Y, and another isometric virus, a tymovirus, referred to as Senna virus X (1).

Ref.: (1) Beserra Jr., J.E.A. et al. Trop.Plant Pathol. 36: 115. 2011.

\section{*Catharanthus roseus (L.) G.Don. (Periwinkle) Apocynaceae Cucumovirus \\ Cucumber mosaic virus (CMV)}

Occurrence of periwinkle plants showing mosaic symptoms on their leaves is quite common in Brazil. The first identification that the condition is caused by CMV was made in the state of São Paulo (1-5). Molecular analysis indicated that CMV isolate infecting periwinkle belongs to the same clade of other Brazilian CMV isolates (6).

Ref.: (1) Costa, A.S. Summa Phytopathol. 9: 39. 1983; (2) Duarte, L.M.L. et al. Fitopatol.bras. 17: 215. 1992; (3) Alexandre, M.A.V. et al. Bol.Tecn. 1: 47. 1995;(4) Espinha, L.M. et al. Fitopatol.bras. 19(supl.): 307. 1994; (5) Duarte et al. Virus Rev.\& Res. 6 (supl.): 155. 2001; (6) Duarte, L.M.L. et al. Tropical Plant Pathol. 33(supl.): S290. 2008.

Potyvirus

Catharanthus mosaic virus (CatMV)

A potyvirus was found in a sample of periwinkle withe leaf mosaic and distortion, from Pirassununga, SP, by electron microscopy (1). Subsequent biological and molecular assays identified the causal agent as a new species of potyvirus, referred to as CatMV (2). Ref. (1). Seabra, P.V. et al. Arq.Inst. Biol. (supl.) 66: 116.1999; (2) Maciel, S.C. et al. Sci.Agric. 68: 687. 2011. 


\section{*Cayaponia tibiricae (Naud.) Cogn., Cucurbitaceae Potyvirus \\ Zucchini yellow mosaic virus (ZYMV)}

This Brazilian wild cucurbit was found exhibiting mosaic symptoms in Atibaia, SP. Further assays indicated that the causal agent was ZYMV, suggesting that this plant may serve as a natural reservoir for ZYMV (1).

Ref.: (1) Yuki, V.A. et al. Plant Dis. 83: 486. 1999.

\section{*Centrosema brasilianum L. Fabaceae}

Begomovirus

Centrosema yellow spot virus (CeYSV)

Yellow spots on leaves of $C$. brasilianum in the state of Pernambuco was verified to be caused by CeYSV infection (1).

Ref.: (1) Silva, J.C.V. et al. Plant Pathol. 61: 457. 2012.

\section{*Centrosema pubescens Benth. Fabaceae}

Comovirus

Cowpea severe mosaic virus (CPSMV)

CPSMV, serotype I, was found infecting C. pubescens in Brasília, DF (1).

Ref.: (1) Lin, M.T. \& Anjos, J.R.N. Plant Dis. 66: 67. 1982

Potyvirus

\section{Potyvirus unidentified}

Unidentified potyvirus was found by electron microscopy, coinfecting phytoplasma in $C$. pubescens in an experimental plot of Embrapa Gado de Corte, Campo Grande, MS (1). This virus was later purified and a specific antiserum, produced. However, further works for its identification were not conducted (2).

Ref.: (1) Kitajima, E.W. et al. Fitopatol.bras. 16: XXV.1991; (2) Batista, M.F. et al. Fitopatol. Bras. 20: 339. 1995.

\section{*Cestrum nocturnum L. (Night jasmine) Solanaceae}

Dichorhavirus unclassified

\section{Cestrum ringspot virus (CeRSV)}

Chlorotic and ringspots on green leaves, and green spots on senescent leaves were observed in night jasmine in a residential garden in Atibaia, SP, associated with infestation by Brevipalpus mites. Electron microscopy revealed cytopathology typical of dichorhavirus in tissues from the lesions (1). The disease was transmitted by B. phoenicis s.l. and B. obovatus (2).

Ref.: (1) Freitas-Astua, J. et al. Fitopatol. bras. (supl.) 27: 205. 2002;

(2) Summa Phytopathol. 30: 80. 2004

\section{*Chenopodium album L. (Goosefoot) Amaranthaceae} Begomovirus

Tomato severe rugose virus (ToSRV)

Natural infection of goosefoot by ToRSV was registered in Sumaré, SP (1).

Ref. (1) Barbosa, J.C. et al. Trop.Plant Pathol. 33(supl): S286. 2008.

\section{*Chenopodium murale L. (Sowbane) Amaranthaceae}

Sobemovirus

Sowbane mosaic virus (SoMV)

SoMV was first observed in Riverside, CA, USA, causing mottling in sowbane plants. It is an isometric, seed-borne virus, occurring in high concentration in infected tissues. It was transmitted by the hoppers Circulifer tenellus (Baker) and Halticus citri Ashmead, and by the leaf miner fly Liriomyza langei Frick and officially described in 1961 (3). In Brazil, SoMV was found in Campinas,SP, and was the first plant virus to be purified and a specific antiserum to be produced
$(1,2)$.

Ref.: (1) Silva, D.M. et al. Rev.Agricultura, Piracicaba, 32: 189. 1957; (2) Bragantia 17: 167. 1958; (3) Bennett, C.W. \& Costa, A.S. Phytopathology 51: 546. 1961.

*Chrysanthemum frutescens L. (=Argyranthemum frutescens (L.) Sch.Bip.) (Paris Daisy) Asteraceae

Potyvirus

Potyvirus unidentified

A still unidentified potyvirus, though purified and partially characterized, was detected in Paris Daisy in the state of São Paulo (1). Ref.: (1) Paiva, F.A. \& Desjardins, P.R. Fitopatol. Bras. 7: 542, 1982.

\section{*Chrysanthemum leucanthemum L. (Oxeye daisy) Asteraceae} Orthotospovirus

\section{Orthotospovirus unidentified}

Oxeye daisy plants with necrotic spots on their leaves were found in the garden of Hotel Nacional, Brasília, DF, in high incidence. Unidentified Orthotospovirus was found associated with the disease (1).

Ref.: (1) Oliveira, C.R.B. \& Kitajima, E.W. Fitopatol.bras. 14: 89. 1989.

*Chrysanthemum morifolium Ramat. (Florist's daisy) Asteraceae Nucleorhabdovirus

Nucleorhabdovirus unidentified

An unidentified nucleorhabdovirus was detected by electron microscopy in florist's Daisy with yellow stripes on the leaves, sampled in Capão Bonito, SP (1).

Ref.: (1) Kitajima, E.W. \& Costa, A.S. Fitopatol. Bras. 4: 55. 1979

Orthotospovirus

\section{Chrysanthemum stem necrosis virus (CSNV)}

An Orthotospovirus, distinct from previously known species, was identified as the causal agent of stem and leaf necrosis in cultivated florist's daisy, collected in Atibaia, SP (1). Later similar isolates were found in Cotia, Ibiuna and Vargem Grande Paulista, state of São Paulo, infecting mainly cv. Polaris (2). This virus was also found infecting tomato plants, causing systemic necrosis in Viçosa, MG (3). Molecular studies confirmed that it is a new Orthotospovirus species and named CSNV (4). CSNV was also found infecting florist's Daisy in the state of Rio de Janeiro (5).

Ref.: (1) Duarte, L.M.L. et al. J. Phytopathol. 143: 569. 1995; (2) Alexandre, M.A.V. et al. Fitopatol. Bras. 21: 80. 1996; (3) Resende, R.O. et al. Fitopatol. Bras. 20: 299. 1995; (4) Bezerra, I.C. et al. Fitopatol. Bras. 21: 430. 1996; (5) Brioso, P.S.T. et al. Fitopatol. Bras. 29: S140. 2004

Ilarvirus

Ilarvirus unidentified

Unidentified ilarvirus was reported infecting florist's daisy in the state of São Paulo (1).

Ref.: (1) Rivas, E.B. et al. Fitopatol. Bras. 19: 311. 1994

Viroid

Pospiviroid

Chrysanthemum stunt viroid (CSVd)

CSVd was detected by R-PAGE, in the state of São Paulo, infecting florist's daisy (1). It was later characterized by sPAGE, RT-PCR, RTqPCR and sequencing (2).

Ref.: (1) Dusi et al., Plant Pathology 39: 636. 1993;(2) Gobatto,D. et al. J.Plant Pathol. 96: 111. 2014.

*Chrysanthemum sp. (=Dendranthema sp.) (Chrysanthemum), Asteraceae

Pospiviroid 


\section{Chrysanthemum stunt viroid (CSVd)}

CSVd was detected in cultivated Chrysanthemums, by molecular means, in samples collected at Atibaia, Artur Nogueira and Holambra, SP (1).

Ref.: (1) Gobatto, D. et al. Trop.Plant Pathol. 37 (supl.). CDRom. 2012.

*Cicer arietinum L. (Chickpea) Fabaceae

Orthtotospovirus

Tomato spotted wilt virus (TSWV)

Chickpea plants showing chlorosis and distortion of apical leaves were observed in Brasília, DF. The causal agent was identified as an isolate of TSWV (1).

Ref.: (1) Boiteux, L.S. et al. Fitopatol.bras. 19: 278. 1994.

Tobamovirus

Sunn hemp mosaic virus (SHMV)

A tobamovirus was isolated from chickpea showing yellowing and premature death in an experimental plot of the Instituto Agronomico, Campinas, SP (1), which was tentatively identified as SHMV, a tobamovirus specialized for legumes (2).

Ref.: (1) Costa, A.S. et al. Summa Phytopathol. 14: 42. 1988; (2) Fitopatol.bras. 13: 115. 1988

\section{*Cichorium endivia L. (Endive) Asteraceae \\ Orthtotospovirus \\ Tomato chlorotic spot virus (TCSV)}

TCSV was identified as the causal agent of a systemic necrosis on the endive's leaves $(1,2)$.

Ref.: (1) Pedrazzoli, D.S. et al. Summa Phytopathol. 26: 132. 2000;

(2) Colariccio, A. et al. Summa Phytopathol. 27: 325. 2001.

Potyvirus

\section{Lettuce mosaic virus (LMV)}

During a survey of plant viruses in the state of Rio de Janeiro, a low incidence of mosaic affecting endive was noticed. Causal agent was identified as an isolate of LMV (1).

Ref.: (1) Kitajima, E.W. et al. Fitopatol.bras. 9: 607. 1984.

\section{*Cichorium intybus L. (Chicory) Asteraceae}

Orthotospovirus

Orthotospovirus unidentified

Mosaic and yellow spots on chicory leaves have been observed since 1938 in several regions of the state of São Paulo. The etiological agent was considered an Orthotospovirus (1).

Ref.: (1) Costa, A.S. \& Costa, C.L. Rev.Oleric. 11: 33. 1971.

Potyvirus

Potyvirus unidentified

An unidentified potyvirus was found in chicory showing mosaic symptoms in Londrina, PR (1).

Ref.: (1) Mituti, T. et al. Virus Rev.\&Res. 11(supl): 187. 2006.

\section{*Citrullus lanatus (Thumb.) Matsui \& Nakai (Watermelon) Cucurbitaceae \\ Orthotospovirus \\ Groundnut ringspot virus (GRSV)}

Mosaic and leaf distortion was observed in $20-40 \%$ of watermelon plants in commercial fields in the state of Goias, associated with infestation by the thrips Frankliniella schultzei. Molecular assays identified the causal agent as GRSV (1).

Ref.: (1) Lima, M.F. et al. Virus Rev \& Res.20 (supl.): 216-217. 2015

Zucchini lethal chlorosis virus (ZLCV)

Plants of watermelon grown in irrigated area of Guadalupe, PI,were found showing mosaic and leaf deformation. Electron microscopy detected Orthotospovirus infection, and the causal agent was tentatively identified as ZLCV, though further assays are required to confirm this identification (1). Epidemy of ZLCV in watermelon was observed in several areas of Central Brasil (2), including Uruana, GO (3).

Ref.: (1) Beserra Jr., J.E.A. et al. Summa Phytopathol. 39 (supl) CDRom. 2013; (2) Lima, M.F. et al. Trop.Plt.Pathol. 39 (supl.) CD Rom. 2014; (3) Marques, M.L.S. et al. Summa Phytopath. 40 (supl) CDRom. 2014.

Comovirus

\section{Squash mosaic virus (SqMV)}

SqMV was found co-infecting watermelon with PRSV-W, in the states of Piaui (1), Maranhão (2), Rio de Janeiro (3) and Tocantins (4). Ref.: (1) Lima, J.A.A. et al. Fitopatol.bras. 5: 417. 1980; (2) Kitajima, E.W. et al. Fitopatol.bras. 7: 537. 1982; (3) Kitajima, E.W. et al. Fitopatol.bras. 9: 607. 1984; (4) Alencar, N.E. et al. J. Biotechnol. Biodiv. 3: 32. 2011.

\section{Cucumovirus}

\section{Cucumber mosaic virus (CMV)}

Watermelon cultivated in areas of "submédio São Francisco", state of Pernambuco, was found infected with CMV (1).

Ref.: (1) Lima, M.F. et al. Fitopatol.bras. 22: 337. 1997

Potyvirus

Papaya ringspot virus $W$ (PRSV-W)

PRSV-W is widespread in cucurbits, including watermelon. It was found infecting commercial plantations of watermelon in the states of Distrito Federal (1), Ceará (2), São Paulo (3), Maranhã (4), Pernambuco (5), Rio de Janeiro (6), Minas Gerais (7), Roraima (8), Santa Catarina (9) and Piauí (10).

Ref.: (1) Cupertino, F.P. et al. Fitopatologia (Lima) 9: 51. 1974; (2) Lima, J.A.A. et al. Fitopatol.bras. 5: 414. 1980; (3) Lin, M.T. et al. Res.20 Cong.Bras.Oleric.: 144. 1980: (4) Kitajima, E.W. et al. Fitopatol.bras. 7: 537. 1982; (5) de Ávila, A.C. et al. Fitopatol.bras. 9: 113. 1984; (6) Kitajima, E.W. et al. Fitopatol.bras. 9: 607. 1984; (7) Pavan, M.A. et al. Fitopatol.bras. 10: 301. 1985; (8) Ferreira, M.A. et al. Fitopatol.bras. 28: S249. 2003; (9) Colariccio, A. et al. Fitopatol. bras. 32 (supl): S306. 2007; (10) Beserra Jr., J.E.A. et al. Summa Phytopathol. 39 (supl) CDRom. 2013.

\section{Watermelon mosaic virus (WMV)}

WMV was detected infecting watermelon in surveys made in the region of "submédio São Francisco", state of Pernambuco (1). Ref.: (1) Lima, M.F. et al. Fitopatol.bras. 22: 337. 1997.

\section{Zucchini yellow mosaic virus (ZYMV)}

ZYMV was first reported in Brazil, in samples of watermelon with mosaic, collected in Votuporanga, SP. Identification was confirmed by biological assays, serology and immuno electron microscopy (1). Later, ZYMV infecting watermelon was also detected in the states of Pará (2), Rondonia (3), Santa Catarina (4), Tocantins (5) and Piauí (6). Ref.: (1) Vega, J. et al. Fitopatol.bras. 20: 72. 1995; (2) Poltronieri, L.S. et al. Fitopatol. Bras. 25: 669. 2000; (3) Ferreira, M.A. et al. Fitopatol.bras. 28: S249. 2003. (4) Colariccio,A et al. Fitopatol.bras. 32 (supl):S306. 2007; (5) Alencar, N.E .et al. J. Biotechnol. Biodiv. 3: 32. 2011.(6) Beserra Jr., J.E.A. et al. Summa Phytopathol. 39 (supl) CDRom. 2013.

\section{*Citrus spp. Rutaceae}

Citrus aurantifolia Christm. (Mexican lime), C. aurantium L. (sour orange), C. grandis (L) Osbeck (pomelo), C. limon (L) Burm.f. (lemmon), Citrus medica L. (citron), C. paradisi Macf. (grapefruit), C. sinensis Osbeck (orange), C. reticulata Blanco (mandarin) Ophiovirus

Citrus psorosis virus (CPsV)

Psorosis in citrus is characterized by chlorosis and formation of 
"oak leaf" pattern in young leaves, scaly bark in stems and trunk, concave gummosis and blind pockets in plants older than 12 years. In Brazil this condition has been found in several citrus growing regions of the state of São Paulo $(1,2)$. In the state of Bahia (BA) similar symptoms occur in citrus, except for the absence of symptoms in young leaves (3), thus psorosis in BA (tBA) seems to be different from the conventional one (5). There is report of $\mathrm{CPsV}$ infection in Poncirus trifoliata (4). Field experiments using protected and nonprotected plants suggest winged vector (6).

Ref.: (1) Rossetti, V. \& Salibe, A.A. O Biologico 27: 29. 1961; (2) Rossetti, V. \& Salibe, A.A. Bragantia 21: 107. 1962; (3) Passos, O.S. et al. Proc.6 th Conf.IOCV p. 135. 1974; (4) Salibe, A.A. Fitopatologia (Lima) 11: 30. 1976; (5) Nickel, O. Fitopatol.bras. 196. 1997; (6) Barbosa, C.J. et al. Res. 14 Conf. IOCV: 143. 1998.

\section{Dichorhavirus}

\section{Citrus leprosis virus $N$ (CiLV-N)}

Within the citrus leprosis syndrome, which have several causal viruses, CiLV-N, also trasmitted by Brevipalpus mite, causes leaf lesions slightly different from those caused by the more aggressive and disseminated CiLV-C (Cilevirus). Leaf lesions tend to be smaller, bright chlorotic spot with a dense central spot. CiLV-N occurs in region of lower temperature and higher altitudes, mostly in backyard orange plants. It has been found in the states of São Paulo, Minas Gerais and Rio Grande do Sul and possibly in Panamá (1). Its genome was completely sequenced from samples collected in Monte Alegre do Sul, São Bento do Sapucaí and Ibiuna, SP, and it was concluded to be a distinct member of the genus Dichorhavirus. B. phoenicis s.s. was identified as the vector (2). A virus causing similar symptoms, with a broader host range, infecting several citrus types was observed in Mexico, but genome analysis demonstrated thet the causal agent is an isolate of Orchid fleck virus (OFV).

Ref.: (1) Rodrigues, J.C.V. et al. Exp.Appl.Acarol. 30: 161. 2003; (2) Ramos-González, P.L. et al. Phytopathology 107: 963. 2017.

\section{Citrus chlorotic spot virus (CiCSV)}

During survey of plant viruses in the state of Piauí, some sweet oranges were found showing chlorotic spots and blotches on the leaves and fruits in Teresina, PI. Electron microscopy of the tissues from lesions revealed cytopathic effects characteristic of dichorhaviruses. These plants were infested by Brevipalpus mites, identified as $B$. yothersi af., considered as possible vector. Molecular assays produced the entire genome sequence of the causal virus, confirming that it is a dichorhavirus, distinct from other known members of this genus, being designated CiCSV (1).

Ref.: (1) Chabi-Jesus, C. et al. Plant Dis. 102: 1588. 2018. Capillovirus

\section{Apple stem grooving virus (ASGV)}

Swollen fruits of Cleopatra mandarin were observed in the state of São Paulo. Biological and molecular assays, complemented by electron microscopy indicated the presence of ASGV in these plants, which causes also a condition known as tatter leaf (1).

Ref.: (1) Lovisolo, O. et al. Fitopatol.bras. 28: 54. 2003.

\section{Marafivirus}

\section{Citrus sudden death associated virus (CSDaV)}

Sudden death of citrus, a highly destructive disease of orange trees, grafted on top of rangpur lime and volkameriana lemmon, characterized by a change in the color of the leaves, which becomes more opaque, followed by a quick decline and death of adult plants in few months. Also a yellowing is apparent in the trunk, at the grafted region. It occurs more fequently in the beginning of the rainy season, when vegetative growth of orange trees is more intense. The disease caught attention in 2001 in the Southern region of the "Triângulo Mineiro", state of Minas Gerais. It quickly spread to commercial grooves and soonafter, to the Northern region of the state of São Paulo (1).
Epidemiological studies suggested that the disease agent had a winged vector, possibly aphids (2). Anatomical studies demonstrated a phloem degeneration in the grafted area, this situation being reminescent of damages caused by Citrus tristeza virus (CTV) in intolerant rootstock/ scion combination (3). An isometric virus, identified as a new species of the genus Marafivirus was found associated with the disease, and named $\mathrm{CSDaV}$ (4-6). This virus is present in orange trees graftinoculated with buds from symptomatic trees, which took about two years to express the symptoms. Asymptomatic orange trees grafted on rootstocks as Cleopatra mandarin or sweet orange, growing next to the affected plants in the field were infected by CSDaV. The virus was detected in aphids which fed on diseases trees, and in plants inoculated with these aphids (7).

Ref.: (1) Gimenes-Fernandes, N. et al. Summa Phytopathol. 27: 93. 2001; (2) Bassanezi et al. Phytopathology 93: 502. 2003; (3) Román, M.P. et al. Plant Dis. 88: 453, 2004; (4) Maccheroni, W. et al. J.Virol. 79:3028. 2005; (5) Barros, C.C.P. et al. Fitopatol.bras. 29: S278. 2004: (6) Harakawa, R. Summa Phytopathol. 30: 101. 2004; (7) Yamamoto, P.T. et al. Plant Dis. 95: 104. 2011.

\section{Closterovirus}

\section{Citrus tristeza virus (CTV)}

By and large, tristeza was the most destructive disease for the citrus industry in Brazil. It destroyed about 10 million orange trees grafted on top of sour orange, mostly in the state of São Paulo in 1940 's. and is an example how a quick response based on scientific researches, permitted the recovery of the culture, and transforming the state of São Paulo as the world largest producer and exporter of orange juice, with more than 200 million planted trees. The disease was tamed by the change of the rootstock, followed by a cross protection using mild strains of the causal virus. Tristeza is caused by Citrus tristeza virus (CTV), transmitted by aphids. It was introduced in South America from South Africa, and quickly spread. In the state of São Paulo tristeza was initially found in grooves of the Paraíba valley (1-3). During the early stages of the occurrence of tristeza, Webber (4) observed the similar diseases described in Java and South Africa, suggesting viral etiology. The postulated winged vector was confirmed as being the aphid Toxoptera citricidus Kirk., originally identified as Aphis tavaresi Del Guercio (5). Symptoms of tristeza in susceptible rootstock/scion combination is characterized by a general decline, reduction of the leaf blade, mineral deficiency symptoms, especially of $\mathrm{Zn}$, on the leaves, rotting of root system, followed by death. Anatomical studies indicated marked changes in the phloem at the grafting region. The disease is considered as a result of the phloem collapse at the grafting zone (primary symptoms) with subsequent degradation of the root system, producing leaf symptoms (secondary symptoms), and death of the plant. Some forms of tristeza causes stem pitting as the result of the collapse of the phloem. On the other hand, mild forms of the disease were also noticed (6-8). Concern about the possibility of introduction of CTV in citrus culture in the US resulted in funds for tristeza research in Brazil, supported by visiting specialists as C.W. Bennett and T.J. Grant in the 1950's, and financial support to the cross-protection project (16). Viral etiology for tristeza gained support when elongated, thread-like particles, present in leaf extracts, were consistently associated with the disease in 1964 (9), which were found in situ in phloem tissues (11). Further works involving purification confirmed the viral nature of tristeza, as being caused by CTV. Cross protection using mild strains of CTV to control severe forms, as those causing stem pitting, was conceived by Giacommetti \& Araújo (10), and executed by Müller \& Costa $(12,13,16)$, to face a threat represented by a very severe variant of CTV, known as "Capão Bonito". This cross-protection or preimmunization program permitted the revival of some citrus forms almost extinct as 'Pera' sweet Orange and Mexican lime. Being phloem limited virus, CTV 
is not mechanically transmissible, but it has been demonstrated that it can be transmitted slashing stems with sharp blades (15). Virus-free clones could be obtained by micrograft (18). The use of monoclonal antibodies and molecular tools demonstrated that a single plant is infected by a complex of several CTV isolates (19). Genome of mild and severe isolates of CTV have been sequenced (20). Infectious clone of CTV is already available, produced by W.O. Dowson's group in Florida (21).

Ref.: (1) Bitancourt, A.A. O Biológico 6: 268. 1940; (2) Moreira, S. O Biológico 8: 269. 1942; (3) Bitancourt, A.A. \& Rodrigues Fo., A.J. Arq.Inst.Biol. 18: 313. 1948; (4) Webber, H.J. O Biológico 9: 345. 1943; (5) Meneghini, M. O Biológico 14: 115. 1948; (6) Bennett, C.W. \& Costa, A.S. J.Agric.Res. 78: 207. 1949; (7) Moreira, S. et al. Rev. Agricultura (Piracicaba) 24: 335. 1949; (8) Grant, T.J. \& Costa, A.S. Phytopathology 41: 114. 1951; (9) Kitajima, E.W. et al. Nature 201: 1011. 1964; (10) Giacometti, D.C. \& Araújo, C.M. Proc.3rd Conf. IOCV: 14. 1965; (11) Kitajima, E.W. \& Costa, A.S. Proc.4th Conf. IOCV p. 59. 1968; (12) Muller, G.W. et al. Rev Soc.Bras.Fitopatol. 2: 33. 1968; (13) Muller, G.W. \& Costa, A. Rev. Soc. Bras. Fitopatol. 5:117. 1972; (14) Muller, G.W. Summa Phytopath. 2: 245. 1976; (15) Garnsey, S.M. \& Muller, G.W. Proc.10 ${ }^{\text {th }}$ Conf. IOCVÇ46.. 1988; (16) Costa, A.S. \& Muller, G.W. Plant Dis. 64: 538. 1980; (17) Muller,G.W. $\&$ Costa, A.S. Proc.Workshop of Citrus Tristeza and T. citricidus in Central America: Development of management strategies and use of biotechnology for control (Maracay): 126-131. 1992; (18) Baptista, C.R. et al. Fitopatol.bras. 20: 288. 1995; (19) Corazza-Nunes, M.J. et al. Res. 14 Conf. IOCV: 133 1998/ (20) Targon, M.L.P.N. et al. Fitopatol.bras. 24: 362. 1999; (21) Satyanarayana, T. et al. Virology 280: 87. 2001.

\section{Cilevirus}

\section{Citrus leprosis virus $C$ (CiLV-C)}

Citrus leprosis (CL) is considered one of the most destructive diseases in the citrus industry, and is characterized by localized lesions (chlorotic and/or necrotic ringspots) on the leaves, stems and fruits. Intense leaf and fruit drop may occur. If untreated, stem lesions may fuse resulting in an inexorable die-back, leading to the plant death in few years. It is transmitted by the tenuipalpid Brevipalpus mites. CL was first reported in Brazil, in the 1930's in the state of São Paulo (SP) (1). Its viral etiology was deduced from the spreading of grafted bark lesion to the recipient bark and presence of virus-like particles in tissues of lesions, and mechanical transmission to some indicator plants besides citrus. The genome of the causal virus was sequenced revealing to be distinct from known plant viruses, and it was officially designated Citrus leprosis virus $C$ (CiLV-C) and the genus Cilevirus was created to incorporate it. Field control of CL is based on mite survey and spraying with acaricide specific for Brevipalpus, a costly process $(2,3)$. CL is widespread in Brazil (besides SP, in the states of Rio Grande do Sul, Paraná, Rio de Janeiro, Minas Gerais, Goiás, Distrito Federal, Mato Grosso do Sul, Bahia, Sergipe, Pernambuco, Pará, Amazonas, Rondonia, Roraima, Acre) (2) and though restricted to the American continent, it is present from Argentina to Mexico and represents presently a serious threat to the orange industry of USA. Though experimentally able to infect a wide range of plant species- up to 40 species of 18 botanical families (4), CiLV-C was, so far, found naturally infecting only Commelina benghalensis L in Brazil (5). Common bean (Phaseolus vulgaris) demonstrated to be an excellent indicator plant, since it reacts to mite inoculated CiLV-C in five days, compared to 3-4 weeks, in sweet orange (6). A new isolate of CiLV-C, referred to as São José do Rio Preto (SRP), molecularly distinct from the standard isolate (Cordeirópolis- CRD) has been identified and is being rapidly disseminating in SP (7). After changes in the taxonomy of mites of B. phoenicis group (8), B. yothersi was identified as CiLV-C vector. Beard et.al. (8) and Sanchez-Velasquez et al. (9) are credited by this identification, though they mention only its presence in leprosisaffected citrus orchards. Experimental transmission of CiLV-C by $B$. yothersi was reported by Ramos-González et al. (7). B. papayensis was demonstrated to experimentally transmit CiLV-C (10).

Ref. : (1) Bitancourt, A.A. Arq.Inst.Biol. 22: 161. 1955; (2) Bastianel, M. et al. Plant Dis. 94: 284. 2010; (3) Rodrigues, J.V.R. et al. Exp. Appl.Acarol. 30: 161. 2003; (4) Garita et al. Trop.Plant Pathol. 39: 43. 2014; (5) Nunes et al., Plant Dis.96: 770. 2012; (6) Garita et atl., Plant Dis. 97:1346. (7) Ramos-González, P.L. et al. Viruses 8: 153, 2016; (8) Beard, J. et al. Zootaxa 3944. 2015; (9) Sanchez-Velasquez et al.PLosOne 10:1. 2015; (10) Nunes, M.A. et al. Plant Dis. 102: 1946. 2018

\section{Enamovirus}

\section{Citrus vein enation virus (CVEV)}

First report of vein enation in citrus was made with lemmon grafted on Volkameriano lemmon in commercial grooves of the state of São Paulo. Woody galls were observed in the scion, suggesting a transmissible agent, possibly similar to vein enation, a disease of possible viral etiology, but with still uncharacterized causal agent. Identification of the condition was made using rough lemmon Florida grafted on rangpur lime (1). There are evidences that the aphid Toxoptera citricidus may transmit this disease (2).

Ref.: (1) Jacomino, A.P. \& Salibe, A.A. Proc.12 Conf. IOCV :357. 1993; (2) Carvalho, S.A. et al. Fitopatol.bras. 28:95. 2001

\section{Apscaviroid}

\section{Citrus dwarfing viroid (CDVd)}

This viroid, previously known as citrus viroid III, was detected in the state of São Paulo in 2001, causing size reduction of infected plants $(1,2)$. A case of co-infection of CDVd and HSVd-Ca (causal agent of xylopsorosis) was reported and characterized in the sweet Orange 'Navelina' (3).

Ref.: (1) Targon, M.L.P.N. et al., Laranja 22: 243. 2001; (2) Eiras, M. et al., Trop. Plant Pathol. 35: 303. 2010.

\section{Hostuviroid}

\section{Hop stunt viroid (HSVd)}

Cachexia or xyloporosis of citrus is a disease characterized by stem pitting in cambial tissues and projections in the bark. Originally considered of viral etiology, it was found that the disease is of viroidal etiology. It was known in the state of São Paulo for decades, but its molecular detection was only made in 1989 (1). Other isolates of HSVd were characterized in Tahiti lemmon and 'Navelina' sweet orange $(2,3)$.

Ref.: (1) Fonseca, M.E.N. \& Kitajima, E.E. Fitopatol.bras. 14: 164. 1989; (2) Eiras,M. et al. Trop. Plant Pathol. 35: 303. 2010; (3) Trop. Plt.Pathol. 38: 58. 2013..

\section{Pospiviroid}

\section{Citrus exocortis viroid (CEVd)}

Exocortis was known as false gummosis since 1947, but better characterized in 1954 in the state of São Paulo (SP) (1) and confirmed as being caused by viroid in the 1970's. Infection by CEVd results in the cracking and scaling of the trunk bark. Some isolates cause stunting. Use of nucelar clones eliminate this pathogen in most of citrus cultivated in SP, except in few clones of Tahiti lemmon. CEVd was characterized molecularly in 1988 (2). A bark-cracking phenotype of 'Tahiti' acid lime was found to be associated with CEVd in the state of São Paulo (3). CEVd was also detected in grapevine (4).

Ref.: (1) Moreira, S. O Agronômico 6:10. 1954; (2) Fonseca, M.E.N. et al. Fitopatol.bras. 13: 145. 1988; (3) Eiras, M. et al. Trop.Plant Pathol. 35: 303. 2010; (4) Eiras, M. et al. Summa Phythopathol. 36 (supl.) CDRom. 2010.

Possible viral diseases 


\section{Zonate chlorosis}

Zonate chlorosis was described in the 1930's in sweet orange, lemmon and grapefruit, in the states of São Paulo and Rio de Janeiro, in the coastal áreas. There were suspected samples from the states of Bahia, Minas Gerais, Paraná and Rio Grande do Sul. Symptoms are represented by chlorotic bands alternating with green areas, producing elliptical rings or irregular symmetrical lines, parallel to the central vein of the leaves. Fruits may exhibit circular or elliptical chlorotic areas in green fruits, and brown archs and rings in mature fruits. Viral etiology was suggested based on certain similarity with leprosis and "concentric ring blotch" (from South Africa) $(1,2)$, but this hypothesis should be confirmed. It was not graft or mechanically transmitted, but greenhouse assays indicated possible transmission by B. phoenicis s.l. mites $(3,4)$. Similar disease was found in the state of Sergipe (5).

Ref.: (1) Bitancourt, A.A \& Grillo, H.V.S. Arch.Inst.Biol. 5: 247. 1934; (2) Bitancourt, A.A. O Biológico 1: 255. 1935; (3) Rossetti, V. et al. Arq.Inst.Biol. 32: 111. 1965; (4) O Biológico 31: 113. 1965; (5) Boari, A.J. et al. Summa Phytopathol. 31: 35. 2005.

\section{Cristacortis}

A condition characterized by narrow invagination, forming concavities in the stems and trunk in 1-2 years old plants. When bark is removed, a ridge is noticeable in its inner portion, which gives the name to the disease. The ridge is formed by tissues of the cortex. In Brazil the first report of cristacortis was made in Mogi Guaçú, SP, in a groove of Clementina mandarin, imported from Spain. Symptoms were observed in Hamlin orange, which served as rootstock. Thermotherapy has been used to free the pathogen from infected plant (1). Viral etiology was not demonstrated yet. There is a report of this codition in citron in the Southern Minas Gerais state (2).

Ref.: (1) Rossetti, V. Anais III Cong.Bras.Frutic. vol. 1:117. 1975; (2) Botrel, N. et al. Pesq.Agropec.Bras. 26: 2075. 1991.

\section{"Rumple"}

"Rumple" is a disease which affects fruits of some lemmon clones. It is known to occur in Florida (USA), Ethiopia, Cyprus, Lebannon, Italy and Turkey. Viral nature of the etiological agent has not been demonstrated yet. In Brazil, a possible case of rumple was reported in the Citrus Center of the Instituto Agronomico, in Cordeirópolis, SP, in Lisbon lemmon. Symptoms were irregular depressions on the fruit skin, which evolved from yellowish green color to dark brown (1). There is another report of "rumple"-like condition in the state of Rio Grande do Sul (2).

Ref.: (1) Salibe, A.A. Cien.Cult. 23 (supl.): 221. 1971; (2) Rossetti, V. et al. Proc. $9^{\text {th }}$ Conf. IOCV p. 180. 1984.

\section{Citrus leaf curl}

A citrus disease characterized by leaf curl and die back. In Brazil is known as "crespeira", being graft transmissible. Viral etiology suspected, but not confirmed yet $(1,2)$.

Ref.: (1) Salibe, A.A. Plant Dis.Reptr. 43: 1081. 1959; (2) Proc.3 ${ }^{\text {rd }}$ Conf. IOCV: 175. 1965.

\section{*Cleome affinis DC. Capparaceae \\ Cucumovirus}

\section{Cucumber mosaic virus (CMV)}

A mosaic in C. affinis was reported to be caused by CMV infection in the Zona da Mata, state of Pernambuco (1).

Ref: (1) Nicolini, C. et al. Trop.Plt Pathol. 34(supl): S271. 2009.

Begomovirus

\section{Cleome leaf crumple virus (CILCrV)}

A golden mosaic was observed in C. affinis in Campinas, SP, and considered to be caused by a whitefly transmitted virus of the infectious chlorosis of malvacea complex (1). A similar disease was noticed in the state of Pernambuco and partially sequenced $(2,3)$. Other isolates were described in the states of Alagoas and Pernambuco
(4). Several isolates were obtained in the states of Amazonas, Tocantins, Mato Grosso, Goiás, Pernambuco and Bahia. Molecular analysis divided these isolates into three groups, with similarities to some known begomoviruses as SmMV, ToYSV and SiYLCV, but they were considered as being a new begomovirus species, CILCrV (5). Comparison of several samples collected in the Northeast of Brazil revealed that all of them were essentially identical do ClLCrV from MT (6).

Ref.: (1) Costa, A.S. Summa Phytopathol. 6: 3. 1980; (2) Lima, G.S.A. et al. Virus Rev.\& Res. 6: 158. 2001 (3) Listik, A.F. et al. Summa Phytopathol. 32:397. 2006; (4) Assunção, L.P. et al. Planta Daninha 24: 239.2006; (5) Fernandes, N.A.N. Tese Dr. UnB. 2010; (6) Silva , S.J. et al. Arch.Virol. 156: 2205. 2011.

*Clerodendrum x speciosum Tiejism.\& Binn. (Bleeding heart), $C$. thomsonae Balf. (Glory bower)

C. splendens G. Don. (Flaming glory bower). Lamiaceae

Dichorhavirus

Clerodendrum chlorotic spot virus (CICSV)

C. $x$ speciosum plants exhibiting chlorotic/necrotic spots on their leaves were found in several residential gardens and public parks in Piracicaba, SP, associated with infestation by the tenuipalpid mite Brevipalpus phoenicis s.l. Similar condition was observed in plants of $C$. thomsonae and $C$. splendens. Ultrastructural observation in tissues of the lesions demonstrated cytopathic effects typical for dichorhaviruses (1). Experimental transmission with Brevipalpus mites collected from diseased plants to healthy ones was successful, reproducing the symptoms. The virus was named ClCSV. There are evidences of mite transmission of ClCSV to other plant species (2). Vector-virus relationship seems to be of persistent-circulativereplicative type, since there are ultrastructural evidences that ClCSV replicates in the mite vector $(3,7)$. This virus was purified and there is a specific anti-serum available (4). ClCSV was recorded in the state of Amazonas (5). ClCSV has been partially sequenced and may be detected by RT-PCR, in both infected plants and in mites which fed on symptomatic leaves (6). Complete sequence of ClCSV was obtained, confirming to be a dichorhavirus (7).

Ref.: (1) Kitajima, E.W. et al. Scientia Agricola 63: 36. 2008; (2) Ferreira, P.T.O. et al. Fitopatol. Bras. 29 (supl) 78. 2004; (3) Kitajima, E.W. et al. Virus Rev.\&Res. 11 (supl): 188. 2006. (4) Kubo, K.S. et al. Fitopatol. Bras. 31 (supl): S184. 2006; (5) Rodrigues, J.C.V. et al. Trop. Plant Pathol. 33: 12. 2008; (6) Kubo, K.S. et al. Summa Phytopathol. 34(supl.): S97. 2008; (7) Kitajima, E.W \& Alberti, G. Zoologica 160: 173. 2014; (7) Ramos-González, P.L. et al. Arch.Virol. 163: 2519. 2018.

Rhabdoviridae

\section{Rhabdovirus unidentified}

There is a report of detection of an unidentified rhabdovirus in $C$. thomsonae with vein clearing symptoms. This virus was graft transmitted to tobacco and Nicotiana glutinosa, besides glory bower (1).

Ref.: (1) Schutta, L.R. et al. Summa Phytopathol. 23: 54. 1997

Cilevirus

\section{Cilevirus unidentified}

Green spots on senescent leaves of $C$. thomsonae associated with infestation by Brevipalpus phoenicis s.l. mites, which experimentally transmitted the condition to healthy plants. Electron microscopy revealed cytopathic effects similar to those caused by cileviruses (1). In a few samples, cytopathic effects caused by dichorha- and cilevirus were found in the same cell from the lesion, clearly indicating a double infection, adding another evidence that the two infecting viruses were unrelated (2).

Ref.: (1) Kitajima, E.W. et al. Scientia Agricola 63: 36. 2008; (2) Kitajima, E.W. et al. Exp.Appl.Acarol. 30: 135. 2003. 
*Clitoria fairchildiana R.A. Howard Fabaceae

Begomovirus

Begomovirus unidentified

Transmission assays and PCR tests detected a begomovirus, yet to be identified, in C. fairchildiana in the state of Rio de Janeiro (1). Ref. (1) Brioso, P.S.T. Virus Res.Rev. 19 (supl.2): 216. 2014.

*Clitoria ternatea L. (Asian pidgeonwings) Fabaceae Potyvirus

Potyvirus unidentified

An unidentified potyvirus, possibly related to BCMV, was found naturally infecting $C$. ternatea, causing mosaic symptoms in the state of Ceará. The virus was purified and a specific antiserum was produced (1-3).

Ref.: (1) Lima, J.A.A. et al. Fitopatol.bras. 6: 523. 1989; (2) Lima, J.A.A. et al. Fitopatol Bras.18: 213. 1993; (3)19: 312. 1994.

\section{*Cnidoscolus urens (1.) Arthur (Bull nettle) Euphorbiaceae}

Begomovirus

Cnidoscolus mosaic leaf deformation virus (CnMLDV)

A golden mosaic was observed in $C$. urens associated with a begomovirus, in the state of Alagoas (1). Molecular analysis of this virus indicated that it was new species of begomovirus, and was named CnMLDV (2).

Ref. (1) Assunção, L.P. et al. Planta Daninha 24: 239.2006; (2) Melo, A.M. et al. Arch.Virol. 161: 2605. 2016.

\section{*Coffea arabica L., Coffea spp. (Coffee) Rubiaceae \\ Dichorhavirus}

\section{Coffee ringspot virus (CoRSV)}

Ringspots on leaves and berries of coffee plants were first described in Caçapava, SP, viral etiology being suggested (1). Later works confirmed the viral nature of the disease by detection of cytopathic effects typical of dichorhaviruses (2), mechanical and mite (Brevipalpus phoenicis s.l.) transmission $(3,4)$ and the virus referred to as CoRSV. It has been considered of marginal economical importance but in the 1990's cases of high incidence in Southern region and Triângulo Mineiro, the state of Minas Gerais, with losses due to the intense defoliation and reduced yields $(6,7)$ and also because berries with lesions resulted in beverage of lower quality $(10,13)$. CoRSV is mechanically transmissible to several assay plants, and in some of them, systemic infection may result if plants are kept in higher temperatures (11). The virus was purified and a specific antiserum obtained (12), and its genome was partially sequenced (14). CoRSV was suspected to be grouped with OFV, though serological relationships were distant (13). CoRSV was also detected in Distrito Federal (5) and in the states of Paraná (8) and Bahia (16), and outside Brazil, there is only a register in Costa Rica (9). Other Coffea species and some hybrids of the germplasm bank of Centro do Café, Instituto Agronomico, Campinas, SP, were found naturally infected by CoRSV, as well as one non Coffea species (Psilanthus ebracteolatus, Rubiaceae) (15). Genome of an isolate of CoRSV from Lavras was sequenced, confirming this virus as a member of the genus Dichorhavirus (17). The mite vector of CoRSV was reassessed experimentally as $B$. papayensis (18).

Ref.: (1) Bitancourt, A.A. O Biológico 4: 405. 1938; 5: 33. 1939; (2) Kitajima, E.W.. \& Costa, A.S. Ciência e Cultura 24: 542. 1972; (3) Chagas, C.M. O Biológico 39: 229. 1973; (4) Chagas, C.M. et al. Phytopathol.Zeit.102: 100. 1981; (5) Branquinho, W.G. et al. Fitopatol.bras. 12: 140. 1988; (6) Juliatti, F.C. et al. Fitopatol.bras. 20: 337.1995; (7) Figueira, A.R. et al. 20: 299. 1995; (8) Rodrigues, J.C.V. \& Nogueira, N.L. Fitopatol.bras. 26: 513. 2001; (9) Rodrigues, J.C.V. et al. Plant Dis. 86: 564. 2002; (10) Boari, A.J. et al. Virus Rev.\&Res.
8 supl:192.S246. 2003; (11) S247. 2003; (11) Summa Phytopathol. 30: 453. 2004; (12) Boari, AJ et al. Summa Phytopathol. 32: 192. 2006; (13) Locali, E.C. et al. Fitopatol.bras. CDRom. 2008; (14) Kitajima,EW et al. Sci.Agric. 68: 503. 2012; (15) Almeida, J.E.M. \& Figueira, AR Coffee Science 9: 558. 2014.; (16) Ramalho,T.O. et al. Virology 464-465: 385. 2014; ; (17) Nunes, M.A. et al. Plant Dis. 102: 1046. 2018.

\section{*Coleus blumei Benth. (Coleus) Lamiaceae Coleviroid \\ Coleus blumei viroid 1 (CbVd 1)}

During a survey to find plants susceptible to the Citrus exocortis viroid (CEVd), some C. blumei were found naturally infected by an unidentified viroid. This viroid was considered of a new species, and named CbVd1 $(1,2)$, which was later detected in other countries.

Ref.: (1) Fonseca, M.E.F. et al. Plant Dis. 74: 80. 1990; (2) Fonseca, M.E.N. et al., J Gen.Virol.-75: 1447. 1994.

\section{*Colocasia esculenta (L) Schott. (Taro) Aracae \\ Potyvirus \\ Dasheen mosaic virus (DsMV)}

Taro plants showing mosaic on their leaves were observed in Brasília, DF, and found to be infected by an isolate of DsMV, which was also detected in many other aroids, edible and ornamental (1). The virus was reported infecting taro in the state of Rio de Janeiro (2). Ref.: (1) Rodrigues, M.G.R. et al. Fitopatol. Bras. 9: 291. 1984; (2) Kitajima, E.W. et al. Fitopatol. Bras. 9: 607. 1984;

\section{*Commelina benghalensis L., Commelina spp., (Wandering jew) Commelinaceae \\ Orthotospovirus \\ Orthotospovirus unidentified}

Commelina spp. plants were found to be infected by an unidentified Orthotospovirus in the state of São Paulo, with thin lines, forming symmetrical figures along the veins (1).

Ref.: (1) Pavan, M.A. et al. Fitopatol.bras. 17: 186. 1992.

Cucumovirus

\section{Cucumber mosaic virus (CMV)}

First reference of infection of Commelina spp. by CMV was made in 1940's by Silberschmidt \& Nóbrega, on plants growing close to banana plantation (1). An isolate of CMV recovered from C. agraria was used to compare other isolates of CMV (2). C. benghalensis and $C$. erecta with mosaic symptoms from three different regions of the state of São Paulo were found infected by CMV, based on biological and serological assays and electron microscopy (3).

Ref.: (1) Silbershcmidt, K. \& Nóbrega, N.L. O Biológico 7: 216. 1941; (2) Brioso, P.S.T. Tese Dr., UnB., 1986; (3) Duarte, L.M. et al. Fitopatol. Bras. 19: 248. 1994.

\section{Cilevirus}

\section{Citrus leprosis virus $\boldsymbol{C}$ (CiLV-C)}

Natural infection of $C$. benghalensis growing among sweet orange trees in an organic orchard by CiLV-C, associated with Brevipalpus phoenicis s.l. mite infestation was described in the state of São Paulo (1).

Ref.: (1) Nunes, M.A et al. Plant Dis. 96: 770. 2012.

Potyvirus

\section{Potyvirus unidentified}

A still unidentified potyvirus was found associated with mosaic symptoms in Commelina sp. In the state of Rio Grande do Norte (1) and São Paulo (2).

Ref.: (1) Pinheiro, C.S.R. et al. Fitopatol. Bras. 18: 319. 1993; (2) Moura, M.F. et al. Trop. Plant Pathol. 40 (supl.) CD Rom Res. 333.1. 2015. 
*Conyza canadensis (L.) Cronquist (Horseweed) Asteraceae Polerovirus

Potato leafroll virus (PLRV)

Potyvirus

Potato virus Y (PVY)

Field horseweed plants were found infected by PLRV and PVY in the state of Minas Gerais, without a description of symptoms (1). Ref.: Oliveira, C.D. et al. Fitopatol. bras. 21: 427. 1996.

\section{*Corchurus hirtus L. (Orinoco jute) Malvaceae}

Begomovirus

Corchorus mottle virus (CoMV)

Orinoco jute plants were found showing yellow mosaic on their leaves in the state of Paraíba. These plants were found to be infected by a begomovirus, transmissible by biolistic means to some Sida species and Nicotiana benthamiana and named CoMV(1). It is probably similar to a begomovirus recovered from $C$. hirtus with mottling in the state of Pernambuco, molecularly distinct from other known begomoviruses, being closer to AbMBV (2).

Ref.: ( 1) Fontenelle, R.S. et al. Virus Rev.\&Res. 16 (supl.) CDRom. 2011; (2) Blawid, R. et al. Arch. Virol. 158: 2603. 2013.

\section{*Cordyline terminalis (L.) Kunth. (Ti plant) Agavaceae Cilevirus \\ Cilevirus unidentified}

Ringspots were observed on the leaves of Ti plant in the campus of the Agricultural College (ESALQ), Universidade de São Paulo, campus of Piracicaba, SP, associated with infestation by Brevipalpus phoenicis s.l. mites. Electron microscopy revealed cytopathic effects similar to those caused by cileviruses. Causal virus is not identified yet, but it could be related to the Hibiscus green spot viurs (HGSV) which was present nearby (1).

Ref.: (1) Ferreira, P.T.O. et al. Virus Rev. \& Res. 9: 249. 2004.

\section{*Coreopsis lanceolata L. (Lance-leaved coreopsis) Asteraceae}

Nucleorhabdovirus

Nucleorhabdovirus unidentified

Potyvirus

Bidens mosaic virus (BiMV)

Coreopsis lanceolata plants showing conspicuous mosaic on their leaves were found in a city park of Brasília, DF, and found to be caused by an isolate of BiMV. Electron microscopic observation of infected tissues revealed the presence of an unidentified nucleorhabdovirus in some of these plants $(1,2)$.

Ref.: (1) Kitajima, E.W. et al. Fitopatol. Bras. 16: 141.1991; (2) Rodrigues, M.G.R. et al. Fitopatol.bras. 10: 306. 1985.

\section{*Coriandrum sativum L. (Coriander) Apiaceae}

Orthotospovirus

\section{Groundnut ringspot virus (GRSV)}

Coriander is a seasoning vegetable widely cultivated in the Northeast of Brazil. In a commercial plantation in Petrolina, PE, coriander plants with chlorotic rings, malformation of apical leaves and stoppage of growth were noticed. Biological and serological assays demonstrated that the causal agent was GRSV (1).

Ref.: (1) Lima, M.F. et al. Fitopatol.bras. 25: 443. 2000.

\section{*Couroupita guianensis Hook. Lecythidaceae}

Tobamovirus

Pepper mild mottle virus (PMMoV)

PMMoV was detected by serological means, without mention to symptoms and viral identity confirmation by other procedures (1).
Ref. : (1) Santos, F.M.B. et al. Trop.Plant Pathol. 41 (supl.).CDRom. 2016

*Cosmos sulphureus CAV. (= Bidens sulphureus (CAV.) SCH.BIP. (Yellow cosmos) Asteraceae

Nucleorhabdovirus

Nucleorhabdovirus unidentified

Yellow cosmos plants showing mild mottling were observed in a residential garden in Brasília, DF, and possible infection by an unidentified nucleorhabdovirus was found by electron microscopy (1). Ref.: (1) Sá, P. et al. Fitopatol.bras. 16: 141. 1991.

\section{*Cotyledon orbiculata L (Pig's ear) Crassulaceae}

Nucleorhabdovirus

Sonchus yellow net virus (SYNV)

Potyvirus

Cotyledon virus Y (CotYV)

A potyvirus and a nucleorhabdovirus were found in leaf tissues of pig's ear collected in São Paulo, SP. These viruses could be separated by mechanical inoculation, respectively in Datura stramonium and Chenopodium amaranticolor. Serology indicated that the nucleorhabdovirus is related to Sonchus yellow net virus while the potyvirus revealed to be of a new species $(1,2)$, confirmed by further sequence analysis (3) and tentatively named CotVY.

Ref.: (1) Duarte, L.M.L. et al. Fitopatol.bras. 29: S150. 2004; (2) Duarte, L.M.L. et al. Summa Phytopathol. 31: 63. 2005; (3) Duarte, L.M.L. et al. J.Plant Pathol. 96: 143. 2014.

\section{*Crinum sp. (River lily) Amaryllidaceae}

Potyvirus

\section{Potyvirus unidentified}

River lily plants from Londrina, PR, showing mosaic symptoms revealed to be infected by a still unidentified potyvirus by electron microscopy and RT-PCR (1)

Ref.: (1) Barboza, A.L. et al. Fitopatol. Bras. 31: 212. 2006.

\section{${ }^{*}$ Crotalaria juncea L. Fabaceae}

Comovirus

Cowpea severe mosaic virus (CPSMV)

Mosaic and leaf deformation of Crotalaria juncea, observed in Brasília, DF, were found to be caused by serotypes I and II of CPSMV (1).

Ref.: (1) Lin, M.T. \& Anjos, J.R.N. Plant Dis. 66: 67. 1982.

Potyvirus

\section{Cowpea aphid-borne mosaic virus (CABMV)}

Mosaic symptoms were observed in $C$. juncea and $C$. spectabilis growing within an experimental field of passion fruit in Brasília, DF. Biological and serological assays identified the causal agent as an isolated of CABMV (1).

Ref.: (1) Maciel, S.C. et al. Summa Phytopathol. 30: 110. 2004.

Potyvirus unidentified

An unidentified potyvirus was associated to a mosaic in Crotalaria sp. in Campinas, SP. This potyvirus was transmitted mechanically and by aphids to several other legume plants (1).

Ref.: (1) Freitas, D.S. et al. Fitopatol.bras. 23: 317. 1998.

\section{Tobamovirus}

\section{Sunn hemp mosaic virus (SHMV)}

An outbreak of mosaic was observed in an experimental field of C. juncea in Instituto Agronomico, Campinas, SP. The disease was attributed to a tobamovirus, probably SHMV, with suggestion of the presence of a vector (1).

Ref.: (1) Costa, A.S. et al. Fitopatol.bras. 13: 115. 1988. 
*Crotalaria paulinea Schrank. Fabaceae

Comovirus

Cowpea severe mosaic virus (CPSMV)

C. paulinea plants showing mosaic symptoms were noticed in S.Luis, MA. CPSMV was identified as the etiological agent based on biological and serological assays (1).

Ref.: (1) Nascimento, A.K.Q. et al. Fitopatol.bras. 29: S49. 2004.

\section{*Cucumis anguria L. (Cackrey) Cucurbitaceae} Orthotospovirus

\section{Zucchini lethal chlorosis virus (ZLCV)}

Three cackrey plants, grown under greenhouse conditions in Brasília, DF, were found showing symptoms of possible viral infection. Further biological, serological and molecular assays identified ZLCV as the causal agent (1). Natural infection of cackrey by ZLCV was observed also in the state of S.Paulo (2).

Ref.: (1) Lima, M.F.et al. Virus Rev \& Res.20 (supl.): 217. 2015; (2) Camelo-Garcia, V. et al. Trop.Plt.Pathol. 40: 345. 2015.

Comovirus

Squash mosaic virus (SqMV)

SqMV was detected in $C$. anguria grown nearby Manaus, $\mathrm{AM}(1,2)$ e MA (3).

Ref.: (1) Lin, M.T. et al. Fitopatol.bras. 2: 86. 1977; (2) Kitajima, E.W. et al. Acta Amazonica 9: 633. 1979 (3) Kitajima, E.W. et al. Fitopatol. bras. 7: 537.1982.

Cucumovirus

\section{Cucumber mosaic virus (CMV)}

CMV was found causing mosaic symptoms in cackrey in the states of São Paulo (1) and Rio de Janeiro (2).

Ref.: (1) Lin, M.T. et al. Res.XX Cong.Bras.Oleric. p.144. 1980; (2) Pozzer, L. \& Brioso, P.S.T. Virus Rev.\& Res. 4: 149. 1999.

Potyvirus

Papaya ringspot virus-W (PRSV-W)

A high incidence of chlorotic cakerey plants were registered in Brasília, DF and found dto be caused by an isolate of PRSV-W (1). Similar condition was reported in the states of Amazonas (2), Maranhão (3), Rio de Janeiro (4) and Minas Gerais (5).

Ref.: (1) Cupertino, F.P. et al. Fitopatologia (Lima) 9: 50. 1973; (2) Kitajima, E.W. et al. Acta Amazonica 9: 633. 1979; (3) Kitajima, E.W. et al. Fitopatol.bras. 7: 537. 1982; (4) Kitajima, E.W. et al. Fitopatol. bras. 9: 607.1984 (5) Lima, M.F. et al. Trop.Plt Pathol 35 (supl): S284. 2010.

Zucchini yellow mosaic virus (ZYMV)

ZYMV was found infecting cackrey plants in the state of Minas Gerais, causing yellow mosaic (1).

Ref.: (1) Lima, M.F. et al. Trop.Plt Pathol 35 (supl): S284. 2010.

\section{*Cucumis melo L. (Melon) Cucurbitaceae \\ Orthotospovirus}

Zucchini lethal chlorosis virus (ZLCV)

Few melon plants, grown under greenhouse conditions in Brasília, DF, were found infected by ZLYV (1).

Ref.: (1) Lima,M.F.et al. Virus Rev \& Res.20 (supl.): 217.2015

Comovirus

\section{Squash mosaic virus (SqMV)}

A serological survey made in melon fields in Mossoró, RN, resulted in the detection of SqMV associated with mosaic symptoms (1). There is also report of SqMV infecting melon in the state of Ceará (2).

Ref.: (1) Rocha, H.G.C. et al. Fitopatol.bras. 22: 341. 1997; (2) Silva, E.R. et al. Trop.Plt.Pathol. 38 (supl): 190. 2013.

Carlavirus

Melon yellowing-associated virus (MYaV)

A serious problem characterized by leaf yellowing and loss of brix in the fruits was observed in commercial fields of Mossoró, $\mathrm{RN}$, the main melon producer area in Brazil, and referred to locally as "amarelão" (yellowing). Its transmission by whiteflies was demonstrated (1). There were suggestions that the disease could be caused by a Crinivirus (2), but they were never confirmed. Further works indicated that the syndrome was associated to a whitefly-borne and graft transmissible carlavirus, named $\operatorname{MYaV}(3,4)$. MYaV was also found in the states of Pernambuco and Bahia $(4,5)$ Molecular analysis, after complete genome sequencing, indicated that $\mathrm{MYaV}$ is a carlavirus quite distinct from known members (6).

Ref.: (1) Santos, A.A. et al. Fitopatol.bras. 27: S 211. 2002; (2) Lima, J.A.A. et al. Fitopatol.bras. 27: S 207. 2002; (3) Nagata, T. et al. Plant Pathology 52: 797. 2003; (4) Virus Rev\& Res.9: 29. 2004.(5) Lima, MF et al. Trop Plt Pathol 34(supl) S278. 2009; (6) Costa, T.M. et al. Virus Rev. \& Res.20: 128. 2016.

\section{Cucumovirus}

\section{Cucumber mosaic virus (CMV)}

CMV was found infecting melons and causing mosaic symptoms in commercial plantations in Mossoró, RN (1) and in the state of Rondônia (2).

Ref. (1) Rocha, H.G.C. et al. Fitopatol.bras. 22: 341. 1997: (2) Gonçalves, M.F.B. et al. Fitopatol.bras. 29: S91. 2004.

\section{Polerovirus}

\section{Cucurbit aphid-borne yellows virus (CABYV)}

NGS on samples from melon plants showing severe yellowing allowed the detection of CABYV. Based on the genome sequence it was estimated that the virus has been introduced in Brazil about 68 years ago (1).

Ref.: (1) Costa, T.M. et al. Arch.Virol. 164: 249. 2019.

Potyvirus

\section{Papaya ringspot virus-W (PRSV-W)}

First report of infection of melon by PRSV-W was made in the state of Pará (1), describing symptoms of mosaic, leaf deformation, interruption of the plant development, yield losses, and dissemination by aphids. Later, it PRSV-W was detected on melons in the states of CE (2), SP (3), PE (4), RN (6), BA (7). Sources of resistance towards PRSV-W were reported (5).

Ref.: (1) Albuquerque, F.C. et al. Rev Oleric. 12: 94. 1972; (2) Lima, J.A.A. et al. Fitopatol.bras. 5: 414. 1980; (3) Lin, M.T. et al. Res.20 Cong.Bras.Oleric.: 144. 1980; (4) Choudhury, M.M. \& Lin, M.T. EMBRAPA/CPTSA Pesq.And. 3p. 1982; (5) Della Vecchia, P. \& de Ávila, A.C. Fitopatol.bras 10: 467. 1985; (6) Rocha, H.G.C. et al. Fitopatol.bras. 22: 341. 1997; (7) Cruz, E.S. et al. Summa Phytopathol. 25: 21. 1999

\section{Watermelon mosaic virus (WMV)}

Melons infected by WMV were found with mosaic symptoms, in commercial fields in the submédio S. Francisco, states of Pernambuco and Bahia (1).

Ref.: (1) Cruz, E.S. et al. Summa Phytopathol. 25: 21. 1999.

Zucchini yellow mosaic virus (ZYMV)

Melons with mosaic symptoms, infected by ZYMV detected by serological means, were found in the state of Rio Grande do Norte (1). Ref.: (1) Lima, J.A.A. et al. Fitopatol. Bras. 21: 426.1996.

Gammacarmovirus

Melon necrotic spot virus (MNSV)

Necrotic streaks at the stem base and decline of melon plants were observed in several commercial fields in the states of Rio Grande do Norte and Ceará. Melon seedlings were planted on soils collected from affected fields. Though asymptomatic, molecular assays manage to detect MNSV in these plants. This Brazilian MNSV isolate had a high identity with isolates described previously in Spain (1). Ref.: (1) Moura, M.C.F. et al. Plant Dis. 102: 1049. 2018. 
*Cucumis metuliferus E. Mey (Horned melon) Cucurbitaceae Cucumovirus

Cucumber mosaic virus (CMV)

Potyvirus

Papaya ringspot virus-W (PRSV-W)

During a serological survey of viruses in cucurbits of spontaneous vegetation, in Zona da Mata, state of Pernambuco, plants of horned melon were found infected by CMV and PRSV-W (1).

Ref: (1) Nicolini, C. et al. Trop.Plt Pathol. 34(supl):S271. 2009.

\section{*Cucumis sativus L. (Cucumber) Cucurbitaceae}

Orthotospovirus

Groundnut ringspot virus (GRSV)

Concentric ringspots were observed on leaves of cucumber grown in Vitoriana, SP. GRSV was found to be the causal agent (1).

Ref.: (1) Spadotti, D.M.A. et al. New Dis.Rept. 29: 25. 2014.

Zucchini lethal chlorosis virus (ZLCV)

Infection of cucumber by ZLCV resulted in a yellow mosaic along the veins, followed by severe crinkling and mosaic. Such condition was first described in the state of São Paulo, attributed to a Orthotospovirus (1), which was identified as ZLCV, in a case that occurred in Brasília, DF (2).

Ref.: (1) Costa, A.S. et al. Rev.Oleric. 12: 100. 1972; (2) Nagata, T. et al. Plant Dis. 82: 1403. 1998.

Comovirus

Squash mosaic virus (SqMV)

First report of SqMV infecting cucumber in Brazil was made in a sample collected at Colômbia, SP (1).

Ref.: (1) Chagas, C.M. O Biológico 35: 326. 1970.

Cucumovirus

\section{Cucumber mosaic virus (CMV)}

Infection of cucumber by CMV is rare, and was first registered in the state of São Paulo, in samples showing mosaic symptoms (1), and subsequently reported in the states of Paraná (2), Minas Gerais (3) and Sergipe (5). A comparison of the genome sequence of CMV isolated from cucumber grown in different regions, demonstrated a prevalence os those of subgroup IA, one case of IB, and none of subgroup II (4). Ref.: (1) Costa, A.S. et al. Rev.Oleric. 12: 100. 1972; (2) Lima, M.L.R.Z.C. et al. Fitopatol.bras. 9: 403. 1984; (3) Carvalho, M.G. et al. Fitopatol.bras. 12: 148. 1987; (4) Eiras, M. et al. Fitopatol. Bras. 29: S42. 2004; (5) Almeida, A.C.O. et al. Fitopatol.bras. 31: S322. 2006.

Potyvirus

Papaya ringspot virus W (PRSV-W)

PRSV-W has been the most common virus found infecting cucumber in Brazil, being first registered in the state of São Paulo (1). It causes severe mosaic and leaf malformation (1). The virus was found infecting cucumber in the states of Rio de Janeiro (3), Maranhão (4), Minas Gerais. Studies with inheritance of cucumber resistance to PRSV-W, indicated that it is of polygenic type (2).

Ref.: (1) Costa, A.S. et al. Rev.Oleric. 12: 100. 1972; (2) Silva, N. \& Costa, C.P. Rev. Oleric. 15: 12. 1975; (3) Robbs, C.F. \& Viegas, E.C. Guia de Controle às pragas e doenças das Cult.Econo. do Estado, Sec. Agric.Abast., RJ. 84p. 1978: (4) Kitajima, E.W. et al. Fitopatol.bras. 7: 537. 1982; (5) Pavan, M.A. et al. Fitopatol.bras. 9: 309. 1985.

\section{Zucchini yellow mosaic virus (ZYMV)}

Cucumber sample from Indaial, SC, showing severe mosaic and leaf deformation revealed to be infected by ZYMV, based on biological and serological assays (1).

Ref.: (1) Caner, J. et al. Res. VI Enc.Nac.Virol. p.180. 1992.

*Cucurbita maxima Duch. (Pumpkin) Cucurbitaceae Potyvirus

\section{Papaya ringspot virus W (PRSV-W)}

PRSV-W is commonly found in pumpkin causing mosaic. A good level of resistance to this virus was observed in "abobora-menina" in the state of São Paulo (1). Genetics for pumpkin resistance to PRSC-W has been made (2).

Ref.: (1) Nagai, H. \& Ikuta, H. Res. Cong. An. Soc. Amer. Cien. Hort.-Reg.Tropical 19 (Campinas).p.13. 1981; (2) Maluf, W. \& Sousa, E.L.S. Hort.Bras. 2: 22. 1984.

\section{*Cucurbita moschata L. (Pumpkin, squash) Cucurbitaceae Orthotospovirus \\ Zucchini lethal chlorosis virus (ZLCV)}

Infection of C. moschata by ZLCV results in severe mosaic, yellow mottling, leaf distortion and smaller size of the plants and may end with the death. These symptoms were known on this cucurbit, but the identification of the causal virus was only made in 1997 in the state of São Paulo (1).

Ref.: (1) Rezende, J.A.M. et al. Fitopatol.bras. 22: 92. 1997.

Potyvirus

\section{Papaya ringspot virus- $W$ (PRSV-W)}

Mosaic in C.moschata caused by PRSV-W has been reported in the states of CE (1) and R. Janeiro (2).

Ref.: (1) Lima, J.A.A. et al. Fitopatol.bras. 5: 414. 1980; (2) Kitajima, E.W. et al. Fitopatol.bras. 9: 607. 1984.

Watermelon mosaic virus (WMV)

Serodetection indicated the presence of WMV in the state of R.Janeiro, infecting C. moschata (1).

Ref.: (1) Brioso, P.S.T. et al. Fitopatol. bras. 2: 190. 1997.

*Cucurbita moschata Duchesne X C. maxima Duchesne (Hybrid pumpkin, Tetsukabuto) Cucurbitaceae

Nucleorhabdovirus

\section{Nucleorhabdovirus unidentified}

A sample of this hybrid cucurbit showing mosaic symptoms from Sta.Izabel, state of Pará, revealed to be infected by an unidentified nucleorhabdovirus, by electron microscopy (1).

Ref.: (1) Kitajima, E.W. et al. Fitopatol.bras. 16: 141. 1991.

Comovirus

Squash mosaic virus (SqMV)

Tetsukabuto pumpkin with vein clearing, mosaic and blistering collected in Brasíllia, DF, revealed to be infected by SqMV. Identification by serology and electron microscopy, and beetle (Diabrotica bivittula) transmission (1).

Ref.: (1) Batista, M.F. Diss.MS, PG Fitop., UnB, 59p. 1979.

\section{*Cucurbita pepo L. (Pumpkin) Cucurbitaceae}

Comovirus

Squash mosaic virus (SqMV)

SqMV was found in pumpkin with mosaic symptoms in Brasília, DF (1). A high incidence of SqMV in pumpkin was registered in the state of Rio Grande do Sul (2).

Ref.: (1) Cupertino, F.P. et al. Fitopatologia 9: 51. 1974; (2) Siqueira, O. et al. Fitopatologia (Lima) 9: 72. 1974.

Cucumovirus

\section{Cucumber mosaic virus (CMV)}

Pumpkin infected by CMV was found serologically in the state of Rondonia (1).

Ref.: (1) Gonçalves, M.F.B. et al. Fitopatol.bras. 29: S91. 2004.

Alphanecrovirus

Squash necrosis virus (SqNV)

An isometric virus was found co-infecting pumpkin with other viruses, in Brasília, DF. Mechanical transmission assays consistently caused only local lesions in assay plants. This virus occurs in high 
concentration in the lesion tissues. It did not reveal relationship with Tobacco necrosis virus (TNV), and named SqNV (1), but it was transmitted by the fungus Olpidium radicale, which is the vector of other alphanecroviruses Melon necrotic spot gamacarmovirus (MNSV) in Japan and Cucumber necrosis tombusvirus (CuNV) in Canada, though unrelated serologically to SqNV (2).

Ref.: (1) Lin, M.T. et al. Fitopatol.bras. 8: 622. 1983; (2) Lin, M.T \& Palagi, P.M. Fitopatol.bras. 8: 622. 1983.

\section{*Cucurbita pepo L. var. Caserta (Zucchini squash) Cucurbitaceae Orthotospovirus}

Zucchini lethal chlorosis virus (ZLCV)

Orthotospovirus infecting zucchini squash was reported in the state of São Paulo (1, 2), Distrito Federal and Paraná (4). After the 1990's incidence of Orthotospovirus in zucchini squash increased; it was identified and considered a new species among Orthotospoviruses, by serology and molecular assays and designated ZYLV (4-6). The thrips vector was identified as Frankliniella zucchini (7).

Ref.: (1) Costa, A.S. et al. Rev.Oleric. 12: 100. 1972; (2) Kitajima, E.W. \& Costa, A.S. Rev Soc.Bras.Fitopatol. 5: 180. 1972; (3) Cupertino, F.P. et al. Fitopatologia (Lima) 9: 51. 1974; (4) Lima, M.L.R.Z.C. et al. Fitopatol.bras. 9: 403. 1984; (4) Rezende, J.A.M. et al. Fitopatol.bras. 22: 92. 1997; (5) Pozzer, L. et al. Fitopatol. Bras. 21: 432. 1996; (6) Pozzer, L. Tese de Dr., UnB. 104p. 1998 (7) Nakahara S. \& Monteiro R.C. Proc. Entom. Soc. Wash. 101: 290. 1999.

Comovirus

Squash mosaic virus (SqMV)

SqMV was identified infecting zucchini squash in the state of Tocantins (1)

Ref: (1) Alencar, N.E. et al. J. Biotechnol. Biodiv. 3: 32. 2011.

Nepovirus

Tobacco ringspot virus (TRSV)

Natural infection of Zucchini squash by TRSV was reported in Campinas, SP (1).

Ref.: (1) Cupertino, F.P. \& Costa, A.S. Bragantia 29: IX. 1969.

Cucumovirus

Cucumber mosaic virus (CMV)

CMV was registered infecting zucchini squash in the states of Paraná (1) and Minas Gerais (2).

Ref.: (1) Lima, M.L.R.Z.C. et al. Fitopatol.bras. 9: 403. 1984; (2) Carvalho, M.G. et al. Fitopatol.bras. 12: 148. 1987.

Potyvirus

\section{Papaya ringspot virus-W (PRSV-W)}

The first mention of PRSV-W, formerly known as WMV-1, infecting cucurbits was made in the state of São Paulo, during field experiment using reflective surface to reduce aphid incidence (1). Most cucurbits are susceptible to PRSV-W, an aphid-borne virus, and the infection results in mosaic, blistering and thinning of the leaf extremities, reduced growth of the plant, fruits with blistering, smaller size, and overall reduction of the yield. PRSV-W has been registered in zucchini squash in Brasília, DF (2), and in the states of Rio de Janeiro (3), Paraná (4) and Minas Gerais (5). Mild strains has been successfully used for control by cross-protection (6).

Ref.: (1) Costa, C.L. \& Costa, A.S. Rev. Oleric. 11: 24. 1971; (2) Cupertino, F.P. et al. Fitopatologia (Lima) 9: 61. 1974; (3) Robbs, C.F. \& Viegas, E.C. Guia de Controle às pragas e doenças das Cult.Econo. do Estado, Sec.Agric.Abast., RJ. 84p. 1978; (4) Lima, M.L.R.Z.C. et al. Fitopatol.bras. 9: 403. 1984; (5) Pavan, M.A. et al. Fitopatol.bras. 10: 309. 1985; (6) Rezende, J.A.M. et al. Fitopatol.bras. 19: 55. 1994. Watermelon mosaic virus (WMV)

WMV was detected during a screening for virus infection of zucchini squash in Campinas, SP (1), and the identity of the virus was confirmed by further biological and serological assays (2). WMV infecting zucchini squash was observed in sub-médio S. Francisco, state of Pernambuco (3).

Ref.: (1) Crestani, O. et al. Res. Virológica 87 (Maceio, AL). 1987; (2) de Sá, P. \& Kitajima, E.W. Fitopatol.bras. 16: 217. 1991; (3) Dusi, A.N. et al. Fitopatol.bras. 15: XXVI. 1999.

Zucchini yellow mosaic virus (ZYMV)

ZYMV infecting zucchini squash was found in the states of São Paulo (1) and Tocantins (2).

Ref.: (1) Vega, J. et al. Fitopatol.bras. 20: 72. 1995; (2) Alencar, N.E. et al. J. Biotechnol. Biodiv. 3: 32. 2011.

\section{Potyvirus unidentified}

Zucchini squash was found infected by a potyvirus, unrelated serologically to other known potyvirus which infect cucurbits. It is aphid-borne, and has been purified and a specific antiserum was produced (2). However, the identity of this virus remains obscure.

Ref.: (1) Santos, C.D.G. et al. Summa Phytopathol. 16: XXVIII. 1991; (2) Lima, J.A.A. Fitopatol.bras. 19: 294. 1994.

\section{*Cyamopsis tetragonolobus (L) Taub (Guar) Fabaceae \\ Potyvirus}

\section{Bean common mosaic virus (BCMV)}

Guar plants from a multiplication field in Cambé, PR, were found with mosaic symptoms. Biological and serological tests and electron microscopy indicated tat the causal agent was BCMV (1).

Ref.: (1) Faria, M.L. et al. Fitopatol.bras. 15: 127. 1990.

\section{*Cybistax antisyphilitica (Mart.) Mart. (Green ipê) Bignoniaceae} Potyvirus

\section{Watermelon mosaic virus (WMV)}

\section{Zuchini yellow mosaic virus (ZYMV)}

A survey made on a nursery of woody plants, in Distrito Federal, these potyviruses were found by biological assays. No mention to the symptoms nor further confirmation of virus identities (1).

Ref.: (1) Batista, J.G. et al. Virus Rev. \& Res. 21: 122. 2016

\section{*Cyclanthera pedata (L.) Schrad. var. edulis (Slipper gourd) Cucurbitaceae \\ Cucumovirus \\ Cucumber mosaic virus (CMV)}

CMV was detected in Slipper gourd plants in the germplasm collection of Embrapa Hortaliça, Brasília, DF (1).

Ref.: (1) Lima, M.F. et al. Trop.Plt.Pathol. 38 (supl.): 208. 2013.

Potyvirus

Papaya ringspot virus $W$ (PRSV-W)

C. pedata plants showing mosaic symptoms were found in Anhembi, SP, and found to be infected by an isolate of PRSV-W (1). Similar finding was made in the Federal District (2).

Ref.: (1) Rezende, J.A.M. Plant Dis. 84: 1155. 2000; (2) Lima, M.F. et al. Trop.Plt.Pathol. 38 supl.) 208. 2013.

\section{*Cydonia oblonga MILL. (Quince) Rosaceae Unidentified virus}

Leaf ringspots in quince, observed in the state of São Paulo, was considered of possible viral etiology (1).

Ref.: (1) Issa, E.O Biológico 25: 80. 1959.

\section{*Cymbopogon winterianus Jowitt (Citronella) Poaceae Potyvirus \\ Sugar cane mosaic virus (SCMV)}

Natural infection of SCMV in citronella was observed in a germplasm collection of the Instituto Agronomico, Campinas, SP, resulting in mosaic and stunting. The virus was mechanically transmissible and identified as an isolate of SCMV (1). 
Ref. (1) Costa, A.S. et al. Bragantia 10: 301. 1950.

\section{*Cynara scolymus L. (Artichoke) Asteraceae}

Ilarvirus

\section{Tobacco streak virus (TSV)}

Low incidence of witch's broom and leaf malformation symptoms were observed in artichoke samples from Piedade, SP. Biological assays detected an isolate of TSV in these plants (1).

Ref.: (1) Costa, A.S. \& Tasaka, H. O Biológico37: 176. 1971.

Macluravirus

\section{Artichoke latent virus (ArLV)}

A virus, with similar characteristics with ArLV described in California, USA, was found in artichoke samples, with necrotic symptoms on their leaves, collected in São Roque, SP. Apparently the presence of this virus is unrelated with the observed symptoms (1).

Ref.: (1) Costa, A.S. \& Camargo, I.J.B. Rev.Soc.Bras.Fitopat. 3: 53. 1969.

\section{Tobravirus}

\section{Pepper ringspot virus (PepRSV)}

Yellow bands on artichoke leaves were observed in commercial plantations in Ibiúna e Piedade, SP, with low incidenced. Biological assays and electron microscopy indicated that the tobravirus PepRSV was the causal agent $(1,2)$.

Ref.: (1) Chagas, C.M. et al. O Biológico 35: 13. 1969; 38: 35. 1972; (2) Camargo, I.J.B. et al. Rev.Soc.Bras.Fitopatol. 4: 59. 1971.

D

\section{*Dahlia variabilis Desf. (Dahlia) Asteraceae}

\section{Orthotospovirus}

\section{Orthotospovirus unidentified}

Chlorotic spots and rings were observed on the leaves of dahlia in São Paulo, SP, and the causal agent identified as the same causing "vira-cabeça" of tobacco, presently known as one of the several Orthotospovirus species (1). Orthotospovirus was also found in dahlia in the state of Rio de Janeiro (2).

Ref.: (1) Silberschmidt, K. \& Loureiro, R. O Biológico 32: 270. 1966; (2) Kitajima, E.W. et al. Fitopatol. Bras.9: 607.1984.

Ilarvirus

\section{Tobacco streak virus (TSV)}

TSV was identified infecting dahlia and causing chlorotic rings on the leaves in the state of São Paulo $(1,2)$.

Ref.: (1) Costa, A.S. \& Carvalho, A.M.B. Phytopathol. Zeit. 42: 113. 1961; (2) Roberti, R. et al. Fitopatol. Bras. 17: 194. 1992.

\section{Caulimovirus}

\section{Dahlia mosaic virus (DMV)}

Mosaic and vein banding are the symptoms caused by infection of dahlia by DMV, na aphid-borne virus. In Brazil the first report was made in samples collected in the state of Rio de Janeiro, the virus being detected and identified by electron microscopy (1).

Ref.: (1) Kitajima, E.W. et al. Fitopatol. Bras. 9: 607. 1984

\section{*Datura stramonium L. (Jimson weed) Solanaceae} Orthotospovirus

\section{Zucchini lethal chlorosis virus (ZLCV)}

ZLCV was found infecting field Jimson weed plants in the state of S.Paulo. Identification was made by molecular assays (1).

Ref.: (1) Camelo-Garcia, V. et al. Trop.Plt.Pathol. 40: 345. 2015.

Polerovirus

Potato leafroll virus (PLRV)

An isolate of PLRV, causing yellow top on tomato, was recovered from a field jimson weed plant, with chlorosis (1).

Ref.: (1) Costa, A.S. \& Carvalho, A.M.B. Coopercotia Fev./62,p.34.
1962.

*Daucus carota L. (Carrot) Apiaceae

Polerovirus

Carrot red leaf virus (CaRLV)

A reddening or yellowing of leaves may be present occasionally in carrot cultivated in Brazil. The causal agent has been identified as an aphid [Cavariella aegopodii (Scop.)]-borne virus, CaRLV. This virus has been detected in the states of São Paulo and Minas Gerais (1).

Ref.: (1) Costa, A.S. et al. Supl.Agric.O Estado de S.Paulo 643: 15. 1967; Costa, A.S. et al. Summa Phytopathol. 1: 5. 1975.

Potyvirus

\section{Carrot thin leaf virus (CTLV)}

Symptoms of mild mosaic and thin leaves were observed in a commercial carrot plantation in Piedade, SP. Electron microscopy indicated the association of the condition with a potyvirus, inducing cylindrical inclusion of type II. This virus is mechanically and aphidtransmissible, and was identified as an isolate of CTLV (1-3).

Ref.: (1) Kitajima, E.W. et al. Bragantia 27: XII. 1968; (2) Costa, A.S. et al. Rev. Olericult. 9. 1969; (3) Camargo, I.J.B. et al. Bragantia 30: 31. 1971.

\section{*Desmodium sp. Fabaceae \\ Cucumovirus \\ Cucumber mosaic virus (CMV) \\ Potyvirus \\ Cowpea aphid-borne mosaic virus (CABMV)}

Desmodium sp. plants were found co-infected by CMV and CABMV in the Zona da Mata, state of Pernambuco (1).

Ref (1) Nicolini, C. et al. Trop.Plt Pathol 34 (supl): S271. 2009.

Begomovirus

\section{Desmodium yellow spot virus (DeYSV)}

Golden mosaic symptoms were observed in plants of Desmodium $\mathrm{sp}$. in the state of Alagoas and suspected to be caused by a begomovirus (1). In another similar occurrence, the disease was considered as being caused by a new species of begomovirus, named DeYSV (2).

Ref. (1) Assunção, L.P. et al. Planta Daninha 24: 239. 2006 (2) Lima, A.T.M. et al. Trop Plt Pathol 34 (supl): S275. 2009.

\section{*Dianthus caryophyllus L. (Carnation) Caryophyllaceae}

Alphacarmovirus

\section{Carnation mottle virus (CarMV)}

CarMV was detected in several samples of asymptomatic carnation, collected in different parts of the state of São Paulo. Identification of the virus was based on biological and serological assays, complemented by electron microscopy (1). Later, CarMV isolates from the states of São Paulo and Minas Gerais were detected by molecular means (2). Ref.: (1) Caldari Jr., P. et al. Fitopatol.bras. 22: 451. 1997; (2) Alexandre, M.A.V. et al. Hort.Bras.33: 257. 2015.

\section{*Diascia sp. (Twinspur) Scrophulariaceae \\ Isometric virus, unidentified}

Isometric, virus-like particles were found in twinspur plants suspected of viral infection. No further information is available (1). Ref.: (1) Alexandre, M.A.V. et al. Rev.Bras.Hort.Ornam. 16: 95. 2010.

*Dieffenbachia amoena Hort. ex.Gentil ; D. picta Schott., Dieffenbachia sp. (Dumbcane) Araceae Orthotospovirus

\section{Tomato chlorotic spot virus (TCSV)}




\section{Tomato spotted wilt virus (TSWV)}

TCSV and TSWV have been reported infecting dumbcane plants, without mention to symptoms (1). TCSV, on the other hand, was detected by molecular means in dumbcane plants with chlorotic spots, rings and vein banding on their leaves $(2,3)$.

Ref.: (1) Galleti, S.R. et al. Virus Rev.\& Res. 5: 197. 2000; (2) Rivas, E.R. et al. Fitopatol.bras. 26: 515. 2001. (3) Rivas, E.B. et al. Arq.Inst. Biol. 70: 615. 2003.

Potyvirus

Dasheen mosaic virus (DsMV)

DsMV was serodiagnosed in commercial plants of dumbcane showing mosaic, vein banding and chlorotic spots on their leaves, in the state of São Paulo $(1,2)$.

Ref.: (1) Rivas, E.B. et al. Summa Phytopathol. 24: 71. 1998, (2) Rivas, E.B. et al. Arq. Inst.Biol. 70: 615. 2003

Tobamovirus

\section{Tobacco mosaic virus (TMV)}

Chlorotic spots and rings were observed on leaves of D. picta in the state of S.Paulo, and the causal agent identified as an isolate of TMV (1).

Ref.: (1) Rivas, E.B. et al. Plant Dis. 84:707. 2000.

\section{*Digitaria decumbens Stent (Pangola grass) Poaceae} Fijivirus

\section{Pangola stunt virus (PaSV)}

Pangola plants showing reddening of the leaves and stunting were found in the state of São Paulo. Isometric particles, ca. $70 \mathrm{~nm}$ in diameter, were associated with the disease, in phloem tissues. Causal virus was identified as PaSV (1) and demonstrated to be transmitted by a hopper of the genus Sogata (2).

Ref.: (1) Kitajima, E.W. \& Costa,A.S. Proc.7th Int.Cong.Electron Microscopy (Grenoble, Fr) p.131. 1970; (2) Costa, A.S. \& Kitajima, E.W. Fitopatologia (Lima) 9: 48. 1974.

\section{*Digitaria sanguinalis (L) Scop. (Hairy crabgrass) Poaceae Potyvirus \\ Potyvirus unidentified}

Presence of an unidentified Potyvirus in hairy crabgrass was reported in the in the state of São Paulo. Some assay plants (Gomphrena globosa, Chenopodium amaranticolor) could be mechanically infected (1). Ref.: (1) Vega, J. et al. Summa Phytopathol. 7: 7. 1981.

\section{*Dioscorea spp. (Yam) Dioscoreaceae}

Secoviridae

\section{Dioscorea mosaic associated virus (DMaV)}

A new virus was found in yam plants showing mosaic symptoms. Molecular studies indicated that the sequence of two fragments of ssRNA ( 5 and $3.8 \mathrm{~kb}$ ) are similar to members of the genus Torradovirus (family Secoviridae) (1). This secovirus had their genome completely sequenced and tentatively named DMaV (2).

Ref.: (1) Hayashi, E.A.I. et al. Archives of Virology 161: 317. 2016; (2) Hayashi, E.A.I. et al. Arch.Virol. 162: 317. 2017.

\section{Potyvirus}

\section{Yam mild mosaic virus (YMMV)}

YMMV was detected in plants of yam cv. São Tomé (D. alata) with mosaic symptoms, in Itapissum, PE (1), and in yam cultivated in the state of Paraíba (2). Molecular studies indicated that these isolates are related to those found in Guadelupe (3) and their genomes have been entirely sequenced (4).

Ref.: (1) Andrade, GP et al. Fitopatol.bras. 31: S344. 2006. (2) Andrade,GP et al. Fitopatol.bras. 32 (supl): 322. 2007; (3) Andrade, GP et al. Trop.Plant Pathol. 36 (supl) CDRom 2011; (4) Rabelo Fo., F.A.C. et al. Arch.Virol. 158: 515. 2013.

\section{Yam mosaic virus (YMV)}

A survey in the samples from the germplasm collection of Embrapa Mandioca e Fruticultura, multiplied in Embrapa Horaliças, Brasília, DF, revealed that yam plants of cvs. Yam Giboia and Maresby, showing high incidence of mosaic, were infected by YMV. Electron microscopy confirmed the presence of potyvirus, and the causal virus was transmitted mechanically to healthy yam plants (1). A possible case of infection of yam by YMV was reported in the state of Sergipe (2). YMV has been detected in cultivated yam in the states of Pernambuco and Alagoas (3), Paraíba (4) and Bahia (5).

Ref.: (1) de Ávila, A.C. et al. Fitopatol.bras. 7: 447. 1982; (2) Boari, A.J. et al. Summa Phytopathol. 31: 35. 2005; (3) Pio-Ribeiro, G. et al. Fitopatol.bras. 31 (supl):S309. 2006; (4) Andrade, G.P. et al. Fitopatol.bras. 32 (supl): 322. 2007; (5) Costa, D.P. et al.XVII Enc. Nac.Metodologia e Gestão de Lab. Da Embrapa. 2013.

Badnavirus

Dioscorea bacilliform virus AL (DBV)

DBV was detected by electron microscopy in plants sampled in the state of Sergipe (1). This virus has been also reported in the states of Pernambuco and Paraíba (2), and Alagoas (3), and a possible case in Bahia (4). A study on variability of Brazilian isolates of DBV was made (5).

Ref.: (1) Boari, A.J. et al. Summa Phytopathol. 31: 35. 2005. (2) Paula, D.F. et al. Virus Ver\&Res 11(supl): 189. 2006.(3) Lima, J.S. et al. Virus Rev.\& Res. 15 (supl): 185.2010; (4) Costa, D.P. et al. XVII Enc.Nac.Metodologia e Gestão de Lab. Da Embrapa. 2013; (5) Lima, J.S. et al. Trop.Plant Pathol. 38: 349. 2013.

\section{*Dracaena marginata Lam. (Dragon tree) Dracaenaceae Cilevirus \\ Cilevirus unidentified}

Senescent leaves with green spots, associated with Brevipalpus mite infestation, was observed in dragon tree plants in Piracicaba, SP. Electron microscopy revealed cytopathic effects typical of cilevirus infection (1)

Ref.: (1) Nogueira, N.L. et al. Fitopatol. bras. 29: S234. 2004.

$\mathbf{E}$

\section{*Emilia sagittata DC (Tasselflower) Asteraceae}

Orthotospovirus

Tomato spotted wilt virus (TSWV)

Biological and serological assays detected a case of natural infection of tasselflower by TSWV in São Paulo, SP (1).

Ref.: (1) Colariccio, A. et al. Fitopatol. bras. 21: 423.1996.

\section{*Emilia sonchifolia (L) DC (Lilac tasselflower) Asteraceae} Potyvirus

Potato virus $Y$ (PVY)

A case of natural infection of lilac tasselflower by PVY was registered in the state of Minas Gerais (1).

Ref.: (1) Oliveira, C.D. et al. Fitopatol.bras. 21: 427. 1996.

\section{*Erigeron bonariensis L. (Flax-leaf fleabane) Asteraceae} Potyvirus

\section{Lettuce mosaic virus (LMV)}

Natural infection of E. bonariensis by LMV was reported in the state of São Paulo as assessed by biological, serological and molecular assays, complemented by electron microscopy (1).

Ref.: (1) Chaves, A.L.R. et al. Fitopatol.bras. 28: 307. 2003.

*Eriotheca pubescens (Mart. \& Zucc.) Schott \& Endl. Malvaceae 


\section{Tobamovirus}

Pepper mild mottle virus (PMMoV)

PMMoV was detected by serology in seedlings of $E$. pubescenes in Brasília, DF (1).

Ref.: (1) Batista, J.G. et al. Trop.Plt.Pathol. 40(supl): 354.2. 2015.

\section{*Eruca sativa Hill (Rocket) Brassicaceae}

\section{Comovirus}

Turnip ringspot virus (TuRSV)

An isolate of TuRSV infecting rocket plants was registered in the state of Paraná (1).

Ref. (1) Picoli, M.H.S. et al. J. Phytopathology 160: 55. 2012.

Crinivirus

\section{Tomato chlorosis virus (ToCV)}

Rocket plants showing internerval chlorosis in lower leaves was observed in Mauá, PR. RT-PCR assays revealed that these plants were infected by ToCV (1).

Ref.: (1) Boiteux, L.S. et al. Plant Dis. 100: 1027. 2016.

Potyvirus

\section{Turnip mosaic virus (TuMV)}

Mosaic symptoms were observed in a commercial field of rocket in the region of Botucatú, SP. Biological, serological and molecular assays demonstrated that the symptoms were due to infection by an isolate of TuMV, belonging to the group BR (1).

Ref.: (1) Ribeiro Jr., M.R. et al. Trop.Plt.Pathol. 43: 371. 2018.

\section{*Eryngium phoetidum L. (Long coriander) Apiaceae}

Orthotospovirus

\section{Tomato chlorotic spot virus (TCSV)}

Yellowing, epinasty, small size of leaves, bronzing, vein chlorosis and stunting symptoms were observed in long coriander plants cultivated in Sta.Isabel, PA. RT-PCR assays indicated that these plants were infected by TCSV (1).

Ref.: (1) Quadros, A.F.F. et al. Summa Phytopathol. 42 (supl) res.11. 2016.

*Eucharis grandiflora Planch. \& Linden (Amazona lily) Amaryllidaceae

Orthotospovirus

Tomato spotted wilt virus (TSWV)

Amazon lily plants from a commercial nursery in Atibaia, SP, were found showing chlorotic spots and rings on their leaves. Laboratory tests including biological and RT-PCR assays indicated that these plants were infected by an isolate of TSWV (1).

Ref.: (1) Alexandre, A.M.V. et al. New Dis.Rept. 30: 13. 2014.

Cucumovirus

Cucumber mosaic virus (CMV)

CMV was found infecting Amazon lily with mosaic symptoms, collected in São Paulo, SP, following biological, serological, molecular assays and electron microscopy (1). This isolate of CMV could be grouped in the same clade of other Brazilian isolates (2).

Ref.: (1) Cilli, A. et al. Virus Rev.\&Res. 7: 151. 2002; (2) Duarte, L.M.L. et al. Tropical Plant Pathol. 33(supl.): S290. 2008.

Potyvirus

Hippeastrum mosaic virus (HiMV)

Amazon lily plants infected by CMV was also co-infected by a potyvirus which was identified as HiMV based on RT-PCR assays and sequencing of the resulting amplicon (1).

Ref. (1): Alexandre, M.A.V. et al. Trop.Plt. Pathol. 36 (supl.): CDRom. 2011

*Eugenia uniflora L. (Pitanga, Suriname cherry) Myrtaceae Cilevirus

\section{Cilevirus unidentified}

E. uniflora plants showing chlorotic rings on their leaves were found in Águas de S. Pedro, SP, associated with infestation by Brevipalpus mites. Electron microscopy revealed cytopathic effects typical of cilevirus in the tissues of the lesion (1).

Ref.: (1) Nogueira, N.L. \& Rossi, M.L. Summa Phytopathol. 30: 111. 2004.

*Euphorbia heterophyla L (=E. prunifolia Jacq.), (Wild poinsettia) Euphorbiaceae

Begomovirus

Euphorbia yellow mosaic virus (EuYMV)

Wild poinsettia showing a bright mosaic on their leaves is quite common in most of the Brazilian territory. Originally this condition was described in the state of São Paulo, and demonstrated to be whitefly-borne, and mechanically transmissible to some assay plant species. Occasionally this virus was found naturally infecting other plant species $(1,2)$. An isolate obtained in Brasília, DF, was characterized molecularly as a new begomovirus species, but its biological properties are unknown. Sequence analysis revealed $87.3 \%$ identity with a Peruvian isolate of EuMV, enough to be considered a distinct species, which was named Euphorbia yellow mosaic virus (EuYMV) (3). Some assay plants were infected by EuYMV by biobalistic (4).

Ref.: (1) Costa, A.S. \& Bennett, C.W. Phytopathology 40: 266. 1950; (2) Costa, A.S. \& Carvalho, A.M.B. Phytopathol. Zeit. 38: 129. 1960; (3) Rocha, W.B. et al. Fitopatol.bras. 29 (supl): S148. 2004; (4) Fernandes, F.R. et al. Arch.Virol. 156: 2063. 2011.

Gemycircularvirus

Pteropus associated gemycircularvirus 5 (PaGmV-5)

Molecular assays resulted in the detection of a gemycircular virus in wild poinsettia plants, with similarities in nucleotide sequence with PaGmV-5 (1).

Ref.: (1) Rezende, R.R. et al. Arch.Virol. 163: 3163. 2018.

*Euphorbia splendens Bojer ex. Hook (Christ's thorn) Euphorbiaceae

Ilarvirus

Ilarvirus unidentified

Christ's thorn plants showing chlorotic mosaic and necrotic rings were found in the state of São Paulo. Biological and serological assays, light and electron microscopy indicated that these plants were infected by a still unidentified ilarvirus. (1).

Ref.: (1) Matos, M.F. et al. Fitopatol.bras. 19: 273. 1994.

*Eustoma grandiflorum (Raf.) Shinners (Lisianthus) Gentianaceae Orthotospovirus

Chrysanthemum stem necrosis virus (CSNV)

CSNV was found infecting lisianthus plants in a nursery at Atibaia, SP (1).

Ref. (1) Duarte, L.M.L. et al. Plant Dis. 98: 285. 2014.

\section{Groundnut ringspot virus (GRSV)}

Lisianthus plants with chlorotic mosaic, necrotic rings and foliar deformation were sampled in Atibaia, SP. Further experiments indicated that these plants were double-infected by GRSV and CSNV (1).

Ref.: (1) Alexandre, M.A.V. et al. Summa Phytopathol. 25: 353. 1999

\section{Tomato spotted wilt virus (TSWV)}

An isolate of TSWV was found infecting lisianthus, resulting in stunted plants, and necrotic spots on their leaves (1).

Ref.: (1) Freitas, J.C. et al. Fitopatol. Bras. 21(supl.): 425.1996.

Cucumovirus 


\section{Cucumber mosaic virus (CMV)}

Leaf blistering and necrotic streaks, and witches' broom were observed in lisianthus growing in the state of São Paulo. Laboratory assays identified CMV as the causal agent $(1,2)$.

Ref.: (1) Borsari, P.L. et al. Fitopatol.bras. 22: 332.1997 (2) Alexandre, M.A.V. \& Duarte, L.M.L.(Ed.) Plantas ornamentais: Doenças e Pragas. 319pp. 2008.

Ilarvirus

Tobacco streak virus (TSV)

Lisianthus from commercial plantations in the state of São Paulo were found infected by a possible ilarvirus (1), identified as TSV (2). Symptoms were chlorotic or necrotic spots and rings on their leaves. Ref.: (1) Rivas, E.B. et al. Fitopatol. Bras. 19:311. 1994; (2) Freitas, J.C. et al. Fitopatol. Bras. 21(supl.): 425.1996.

Tobravirus

Pepper ringspot virus (PepRSV)

Samples of lisianthus from Jundiaí, SP, exhibiting mosaic, necrotic lines on the leaves and color breaking of flowers. The causal agent was identified by biological and serological tests and electron microscopy as PepRSV (1).

Ref.: (1) Alexandre, M.A.V. et al. Res. VII Enc.Nac.Virol.: 282. 1996.

$\mathbf{F}$

*Fevillea trilobata L. Cucurbitaceae

Potyvirus

Papaya ringspot virus $W$ (PRSV-W)

Mechanical transmission assays and RT-PCR detected PRSV-W infecting F. trilobata in Brasília, DF (1).

Ref.: (1) Castro, G.M. et al. Plant Dis. 100: 2540. 2016.

Zucchni yellow mosaic virus (ZYMV)

Mosaic symptoms were observed in F. trilobata in a germplasm collection of Embrapa Hortaliças, Brasília, DF. Further biological, serological and molecular assays and electron microscopy identified the causal virus as an isolate of ZYMV (1).

Ref.: (1) Boiteux, L.S. et al. Plant Dis. 97: 1261. 2013.

*Ficus carica L. (Fig) Moraceae

Emaravirus

Fig mosaic virus (FMV)

Fig plants in the state of São Paulo were found with a mosaic, transmissible by eryophiid mites [Aceria ficus (Cotte)] and grafting, and FMV was considered the causal agent $(1,2)$. Virus-infected but asymptomatic plants had no yield losses (3).

Ref.: (1) Zaksveskas, M.L.R. Fitopatologia (Lima) 8: 21a; 21b. 1973; (2) Zaksveskas, M.L.R. \& Costa, A.S. Fitopatologia (Lima) 9: 74. 1974; (3) 10: 65. 1975.

\section{*Fragaria $x$ ananassa Duch. (Strawberry) Rosaceae}

Cytorhabdovirus

Strawberry crinkle virus (SCrV)

The first register of SCrV in Brazil was made in the state of Rio Grande do Sul (RS), in a strawberry collection of IPEAS, in plants showing chlorosis and crinkled leaves (1). The virus was also found in the state of São Paulo (2) and other regions of RS (3).

Ref.: (1) Siqueira, O. Rev.Soc.Bras.Fitopatol. 2: 176. 1968; (2) Betti, J.A. et al. Fitopatologia (Lima) 8: 2. 1973; (3) Nickel, O. et al. Trop. Plt.Pathol. 34 (supl.): S267. 2009.

Secoviridae, undefined genus

Strawberry mottle virus (SMoV)

SMoV-infected cultivated strawberries (interspecific hybrids of Fragaria) are asymptomatic. First register was made in the state of São Paulo (1). This virus may be detected through the use of a wild strawberry (Fragaria vesca) as indicator plant using the aphid vector Pentatrichopus fragaefolii (Ckll). Symptoms in the indicator are represented by pale veins, spots and mosaic, epinasty and roughness on the leaves. Some assays plants as Chenopodium quinoa, Cassia occidentalis, Leonotis nepaetifolia, L. sibiricus could be infected by $\mathrm{SMoV}$ by the aphid, but retroinoculation to $F$. vesca could not be achieved. It is transmissible mechanically to $C$. amaranticolor and $C$. quinoa (1). Electron microscopy revealed isometric viruslike particles in the phloem vessels (2).VIDE and ICTV list SMoV as belonging to the family Secoviridae but in an undefined genus (ICTV, 2011). Recently SMoV had its genome entirely sequenced revealing to be similar to Satsuma dwarf virus, a nepovirus.

Ref.: (1) Carvalho, A.M.B. et al. Bragantia 20: 563. 1961; (2) Kitajima, E.W. et al. Ciência e Cultura 23: 649. 1972.

Ilarvirus

Tobacco streak virus (TSV)

Some strawberry varieties, kept in the germplasm collection of the Instituto Agronomico, Campinas, SP, as well as some introductions, developed vein necrosis, sometimes followed by chlorotic lines or ringspots. The condition was graft transmissible and TSV was identified associated to the disease, through immunoelectron microscopy (1).

Ref.: (1) Vega, J. et al. Summa Phytopathol. 16: 20. 1990.

Alphaecrovirus

Tobacco necrosis virus (TNV)

TNV was recovered from the root system of asymptomatic strawberry plants kept under greenhouse conditions in Instituto Agronomico, Campinas, SP (1).

Ref.: (1) Costa, A.S. \& Carvalho, A.M.B. Bragantia 19: CXLVII. 1960.

Caulimovirus

Strawberry vein banding virus (SVBV)

A virus causing vein banding in the indicator $F$. vesca var. sempeflorens was recovered from asymptomatic hybrid strawberry cultivars in the state of São Paulo. The aphid Chaetosiphum thomasi was able to transmit the virus, which was identified as StVBV (1). Electron microscopy of infected tissues revealed cytopathic effects indicating that StVBV would be a caulimovirus (2), which was later confirmed by biochemical studies made in the USA.

Ref.: (1) Betti, J.A. et al. Fitopatologia (Lima) 8: 73. 1973; (2) Kitajima, E.W. et al. J.gen.Virol. 20: 117. 1973.

G

\section{*Galactia striata (Jacq.) Urb. (Florida hammock milkpea) Fabaceae \\ Begomovirus \\ Bean golden mosaic virus (BGMV)}

A mosaic affecting $G$. striata was observed in several regions of the state of São Paulo, and attributed to an isolate of BGMV, because its transmission to bean by whiteflies, induced golden mosaic (1). Ref.: (1) Costa, A.S. et al. Summa Phytopathol.1 6: 40. 1980.

\section{*Galinsoga parviflora Cav. (Gallant soldier) Asteraceae Polerovirus \\ Potato leafroll virus (PLRV)}

Natural infection of gallant soldier plants by PLRV was reported in the state of Minas Gerais, without mention to symptoms (1). Ref.: (1) Oliveira, C.D. et al. Fitopatol. bras. 21: 427. 1996.

Potyvirus

Bidens mosaic virus (BiMV)

Lettuce mosaic virus (LMV)

Potato virus $Y$ (PVY)

LMV (1) and BiMV (2) were found infecting G. parviflora in the 
state of São Paulo, while in the state of Minas Gerais, this plant was found infected by PVY (3). No mention on possible symptoms was made.

Ref.: (1) Sanches, M.M. et al. Summa Phytopathol 36:346-347, 2010; (2) Sanches, M.M. et al. Summa Phytopathol. 36: 347. 2010; (3) Oliveira, C.D. et al. Fitipatol. bras. 21: 427. 1996.

\section{*Gardenia jasminoides J. Ellis (Gardenia) Rubiaceae Dichorhavirus \\ Dichorhavirus unidentified}

A gardenia plant showing chlorotic spots on leaves were observed in a residential garden in Urucu, AM. Electron microscopy revealed cytopathic effects similar to those caused by dichorhaviruses (1). Ref: (1) Rodrigues, J.C.V. et al. Trop .Plt. Pathol. 33: 12. 2008.

\section{*Gaya guerkeana K. Schum. Malvaceae}

Begomovirus

Gaya yellow mosaic virus (GaYMV)

A possible new species of begomovirus was found in this native malvacea in the state of Alagoas, and named GaYMV. No attempt for biological characterization was made (1).

Ref.; (1) Tenoria, A.A.R. et al. Trop.Plt.Pathol. 38 (supl.): 196. 2013.

\section{*Gerbera jamesonii Bolus ex Hooker f (Transvaal daisy) Asteraceae} Orthotospovirus

\section{Chrysanthemum stem necrosis virus (CSNV)}

Tomato chlorotic spot virus (TCSV)

CSNV and TCSV were found infecting Transvaal Daisy in the state of São Paulo resulting in necrotic spots and vein necrosis on their leaves. Transmission assays, serology and RT-PCR were used to detect these viruses (1).

Ref.: (1) Alexandre, M.A.V.et al. Summa Phytopathol. 29: 69. 2003. Tobravirus

\section{Pepper ringspot virus (PepRSV)}

G. jamesonii plants collected in Cachoeira do Sul, RS, showing chlorotic rings and bands on their leaves, were found to be infected by PepRSV (1).

Ref.: (1) Chagas, C.M. et al. Fitopatol. bras. 12: 346. 1987.

\section{*Gladiolus $x$ hortulanus L.H. Bailey (Gladiolus) Iridaceae \\ Cucumovirus}

\section{Cucumber mosaic virus (CMV)}

Gladiolous plants with mosaic symptoms were found in the state of SãoPaulo. Causal agent was identified as CMV (1).

Ref.: (1) Costa, A.S. Summa Phytopathol. 9: 39. 1983.

Potyvirus

\section{Bean yellow mosaic virus (BYMV)}

Gladiolus infection by BYMV results in mosaic symptoms and such plants may serve as source of inoculum for BYMV for bean crops (1). BYMV in gladiolous was reported in Holambra (2) and Capão Bonito, SP (3).

Ref.: (1) Costa, A.S. et al. Anais I Simp.Bras.Feijão (Campinas). P. 305. 1972; (2) Alexandre M.A.V. et al. Virus Rev. \& Res. 7: 17. 2002; (3) Alexandre, M.A.V. et al. Rev. Bras. Hort. Orn. 16: 95. 2010.

\section{*Gloxinia sylvatica (Kunth.) Whieh (Bolivian sunset) Gesneriaceae Cucumovirus \\ Cucumber mosaic virus (CMV)}

CMV was found infectig G. sylvatica plants, showing chlorotic spots on their leaves in the state of São Paulo. Biological and serological assays were used to identify CMV (1).

Ref. : (1) Alexandre, M.A.V. et al. Rev. Brasileira Hort. Orn. 11: 49. 2005.
Tobravirus

\section{Pepper ringspot virus (PepRSV)}

Symptoms of vein banding on the leaves were observed in Bolivian sunset plants in Brasília, DF. These symptoms were attribute to PepRSV infection based on biological and serological assays complemented by electron microscopy (1).

Ref.: (1) Kitajima, E.W. et al. Fitopatol. bras. 23: 489. 1998.

\section{*Glycine max (L) Merr. (Soybean) Fabaceae Orthotospovirus \\ Orthotospovirus unidentified}

Orthotospovirus infection of soybean seems to be rare in Brazil. First report was made in the state of São Paulo, and some outbreaks may occur depending on the cultivated variety. Symptoms of Orthotospovirus infection are chlorotic spots on lower leaves and systemic chlorotic spots or rings, terminal bud torsion, growth paralysis $(1,2)$.

Ref.: (1) Costa, A.S. et al. $1^{\circ}$ Simp.de Soja (Campinas). 1970; (2) Costa, A.S. et al. Summa Phytopathol. 11: 45. 1985.

\section{Comovirus}

\section{Bean rugose mosaic virus (BRMV)}

BRMV, a beetle-transmitted virus, was found infecting soybean, cultivated in the Federal District, showing mosaic and blistering (1). It was also detected in the state of Paraná causing a rugose mosaic (2) and spots on seed (3). BRMV was also reported in experimental fields of Embrapa Cerrado, Planaltina, DF (4).

Ref.: (1) Cupertino, F.P. et al. Fitopatol.bras. 16: 246. 1991; (2) Martins, T.R. et al. Fitopatol. Bras. 18: 318. 1993; (3) Silva, M.F. et al. Fitopatol.bras. 26: 511. 2001; 4) Anjos, J.R.N. Fitopatol.bras. 17: 151. 1992; (5) Anjos, J.R.N. et al. Fitopatol.bras. 24: 85. 1999.

Cowpea severe mosaic virus (CPSMV)

CPSMV was detected in soybean causing bud blight, in Central Brazil (1) and also in the state of Paraná (2).

Ref.: (1) Anjos, J.R.N. \& Lin, M.T. Plant Dis. 68: 305. 1984; (2) Bertacini, P.V. et al. Fitopatol.bras. 19: 271. 1994.

Carlavirus

\section{Cowpea mild mottle virus (CPMMV)}

CPMMV, a whitefly-borne carlavirus, initially reported in Brazil causing angular mosaic in cv.'Jalo' bean, was able to infect soybean causing mild mosaic and bud blight (1). In 2001 there was an outbreak of bud blight and stem necrosis in soybean fields at Barreiras, BA, the causal agent being identified as CPMMV (2). The virus was also found in the states of Goias, Mato Grosso, Maranhão and Paraná (3), São Paulo (4), Minas Gerais (5) and Pará (6).

Ref.: (1) Costa, A.S. et al. An.II Sem.Nac.Pesq.Soja (Brasilia): 247. 1981; (2) Almeida, A.M.R. et al. Circ.Tecn. EMBRAPA/Soja 36. 2002; (3) Almeida, A.M.R. et al. Fitopatol. bras. 28: S287. 2003; (4) Bicalho, A.A.C. et al. Virus Rev. \& Res. 16 (supl.) CDRom. 2011; (5) Zanardo, L.G. et al. Trop.Plt.Pathol. 38(supl.): 189. 2013; (6) Zanardo, L.G. et al. Trop.Plt.Pathol. 38 (supl.): 190. 2013.

Alfamovirus

Alfalfa mosaic virus (AMV)

AMV was first reported in soybeans in Brazil, in an experimental field of Embrapa Soja, Londrina, PR. This virus caused bright yellowing (calico mosaic) on leaves and stunting of plants (1). Seed transmission occurred in some AMV-infected soybean, and in some cultivars, the virus-induced bud blight (2).

Ref.: (1) Almeida, A.M.R. et al. Fitopatol.bras. 7: 13. 1982; (2) Costa, A.S. et al. Anais II Semin.Nac.Pesq.Soja (Brasília): 264. 1981.

Ilarvirus

Tobacco streak virus (TSV) 
TSV-induced bud blight is commonly seen in more developed soybean plants. Other symptoms include irregular yellow spots on leaves and necrotic streaks along the veins, growth paralysis followed by tip death and bending. Intense axilar budding may occur producing a witches' broom type of appearance to the plant. This condition was first described in the state of São Paulo (1). Seed transmission of TSV may occur (2). Experimental inoculation of soybean by TSV demonstrated that precocious infection may result in almost total yield loss and about 50\%, in late infections (3). Incidence of TSV is present in practically all soybean growing regions, but usually in low incidence. In some varieties, TSV may cause witches' broom symptoms, without bud blight (4).

Ref.: (1) Costa, A.S. et al. Bragantia 14: VII. 1955; (2) Costa, A.S. \& Kiihl, R.A.S. Rev.Soc. Bras. Fitopatol. 4: 35. 1971; (3) Lima No., V.C. \& Costa, A.S. Fitopatologia (Lima) 9: 58. 1974; (4) Scagliusi, S.M.M. \& Costa, A.S. Fitopatol.bras 17: 187. 1992.

Potyvirus

Bean yellow mosaic virus (BYMV)

Mosaic and wrinkling of soybean leaves were found in the state Rio Grande do Sul, and attributed to BYMV infection (1).

Ref.: (1) Hagedorn, D.J. et al. Plant Dis.Reptr. 53: 165. 1969; (2) Costa, A.S. et al. Anais I Simp.Bras.Feijão (Campinas). P. 305. 1972.

Cowpea aphid-borne mosaic virus (CABMV)

CABMV was detected by serology, infecting several soybean lines in a field assay in Teresina, PI (1). Probably is the same isolate recovered from soybean cv.'Tropical', in Fortaleza, CE (2).

Ref.: (1) Santos, A.A. Pesq.Agropec.Bras. 21: 899.1986; (2) Sousa, A.E.B.A. et al. Fitopatol. bras. 21: 470. 1996.

Soybean mosaic virus (SMV)

SMV is probably the most common virus present in soybean crops. First report of its presence was made in the state of Rio Grande do Sul, and afterwards in all soybean producing regions [states of Paraná, São Paulo, Minas Gerais, Mato Grosso do Sul, Mato Grosso, Goiás, Distrito Federal] $(2,3,6,8,9)$. It is naturally disseminated by aphids and infected seeds. Varietal resistance was found. Typical symptoms are mosaic and wrinkling on leaves and spotted seeds, and bud blight in cvs. with resistance of hypersensitivity type (3). Cassia occidentalis is susceptible and may serve as source of inoculum, since it grows commonly nearby soybean fields (4). Seed transmission rate may vary according to the soybean genotype (5). Experimental inoculation may result in black and depressed lesions, of irregular shape in pods of some varieties (7). A condition known as 'yellow shoot' was initially considered caused by a potyvirus distinct from SMV (10), but subsequent molecular works indicated that it is an isolate of SMV $(11,12)$.

Ref.: (1) Vasconcelos, F.A.T. Anais Inst.Sup.Agron. 26: 181. 1963; (2) Issa, E. O Biológico 31: 42. 1965; (3) Costa Lima No., V. Tese Dr. ESALQ/USP. 1974; (4) Costa, A.S. et al. $1^{\circ}$ Simp.de Soja (Campinas). 1970; (5) Porto, M.D.M. \& Hagedorn, D.J. Phtyopathol. 65: 713. 1975; (6) Almeida, A.M.R. Fitopatol.bras. 5: 125. 1980; (7) Almeida, A.M.R. \& Kihil, R.A.S. Fitopatol.bras. 6: 281. 1981: (8) Santos, A.A. Fitopatol.bras. 7: 546. 1982; (9) Figueira, A.R. et al. Fitopatol.bras. 10: 308. 1985; (10) Deslandes, J.A. et al. Summa Phytopathol. 10: 25. 1984: (11) Rezende, J.A.M. \& Costa, A.S. Summa Phytopathol. 12: 187.1986; (12) Santos, R.C. et al. Virus Rev. \& Res. 8: 200. 2003.

\section{Sobemovirus}

\section{Southern bean mosaic virus (SBMV)}

Curved spots in soybean seeds, referred to as 'moustache spots', was found to be caused by an isolate of SBMV in the state of São Paulo (1).

Ref.: Costa, A.S \& Vega, J. Fitopatol.bras. 12: 145. 1987. Begomovirus:

Bean golden mosaic virus (BGMV)
BGMV, which is a serious virus for bean crops, was also found infecting soybean, though not causing serious concern, in the state of São Paulo (1).

Ref.: (1) Costa, A.S. et al. An. Io.Sem.Pesq.Soja II: 145. 1979.

Euphorbia yellow mosaic virus (EuYMV)

Natural infection of soybean by EuYMV resulted in stunting of soybean plants. The symptoms were reproduced through whitefly transmission of the causal virus EuYMV, in the state of São Paulo. Such infection is rare and considered of marginal importance (1). In Luziânia, GO, soybean with interveinal chlorosis and leaf roll symptoms was found to be infected by an isolate of EuYMV, as revealed by molecular assays (2).

Ref.: Ref.: (1) Costa, A.S. et al. $1^{\circ}$ Simp.de Soja (Campinas). 1970; (2)

Tavares, M.L. et al. Virus Rev \& Res.20 (supl.): 192.2015.

"Infectious chlorosis of malvaceae complex" (ICMC)

Okra mottle virus (OMoV)

Sida micrantha mosaic virus (SimMV)

Sida mottle virus (SiMoV)

Mosaic symtoms in soybean caused by whitefly (Bemisia tabaci)transmitted begomoviruses, though not rare, seems to be of minor importance. Early report of begomvirus in soybean was attributed to ICMC. Experimental infection caused yield losses up to $59 \%$ (1). $\mathrm{SiMoV}$ and $\mathrm{OMoV}$ were detected in soybean by molecular means in the state of Goiás $(2,3,5)$. In Brasília, DF, SmMV was detected in soybean used as vegetable (4) and an infectious clone of this virus was obtained (4). SimMV was also found infecting soybean in Distrito Federal (5).

Ref.: (1) Costa, A.S. Phytopathol.Zeit. 24: 97.1955 (2) Mello, R.N. et al. Virus Rev.\& Res. 7: 157. 2002. (3) Fernandes, F. R. et al. Arch. Virol. 154: 1567. 2009.(4) Fonseca, M.E.N. et al. Tropical Plt. Pathol. 34 (supl): S266. 2009; (6) Freitas, D.M.T.A. et al. Virus Rev.\& Res. 19 (supl): 220. 2014.

Soybean chlorotic spot virus (SCSV)

A begomovirus was detected infecting soybean plants, causing chlorotic spots on leaves, in Jaíba, MG. Molecular assays indicate that the causal agent, named SCSV, is distinct from known begomoviruses. It was transmitted by biolistic means, but no attempts of whitefly transmission is reported (1).

Ref.: (1) Coco, D. et al. Arch.Virol. 158: 457. 2013.

Tomato severe rugose virus (ToSRV)

Asymptomatic infection of ToSRV in soybean, planted nearby tomato fields was noticed in samplings made in Central Brazil. Detection was based on PCR assays. Soybean experimentally infected by whiteflies did not show symptoms (1).

Ref.: (1) Macedo, M.A. et al. Plant Dis. 101: 1959. 2017.

\section{*Gnaphalium spicatum LAM. (=Gamochaeta spicata (LAM.) Cabrera) Asteraceae \\ Orthotospovirus \\ Orthotospovirus unidentified}

Chlorotic spots and deformation of leaves were observed in $G$. spicatum plants in the state of São Paulo. Causal agent was identified as an Orthotospovirus (1).

Ref.: (1) Pavan, M.A. et al. Fitopatol.bras. 17: 186. 1992.

Potyvirus

\section{Potato virus Y (PVY)}

G. spicatum was found naturally infected by PVY in the state of Minas Gerais. No reference to symptoms was made (1). Ref.: (1) Oliveira, C.D. et al. Fitipatol.bras. 21: 427. 1996.

*Gomphrena globosa L. (Globe amaranth) Amaranthaceae Nucleorhabdovirus Gomphrena Virus (GoV) 
During virus recovery assays from cultivated plants, a $G$. globosa plant inoculated with a lettuce sample, developed local lesions, in which a nucleorhabdovirus was found. This virus was able to infected several assay hosts. It could not be characterized but it may be related to Sowthistle yellow vein virus (1).

Ref.: (1) Kitajima, E.W. \& Costa, A.S. Virology 29: 523. 1966;

\section{*Gossypium hirsutum L. (Cotton) Malvaceae \\ Ilarvirus \\ Tobacco streak virus (TSV)}

First cases of cotton infection by TSV was reported in the state of São Paulo (1). It was demonstrated that field infection of cotton by TSV requires previous infection, pré-conditioning, by cotton anthocyanosis, an aphid-borne virus, a putative polerovirus (2). Infection alone by TSV is feasible under experimental conditions, but results only in localized infection. Systemic infection by TSV results in stunting, internerval chlorosis, intense axilar budding, and yield losses (1).

Ref.: (1) Costa, A.S. et al. Bragantia 13: I. 1954; Costa, A.S. Phytopath. Zeit. 65: 219. 1969.

Polerovirus

\section{Cotton anthocyanosis virus (CotAV)}

An intense reddening of cotton leaves is caused by CotAV, a putative polerovirus, and transmitted by the aphid Aphis gossipyii Glov. Reddening of the leaves is preceded by chlorotic spots, and these symptoms may be taken as magnesium deficiency. However, contraty to a true $\mathrm{Mg}$ defficiency, application of this element does not revert symptoms $(1,2)$. Anthocyanosis is common in most cotton crops, but in low incidence. The disease has been reported in the states of São Paulo and Bahia (4). Sida rhombifolia, kenaf and okra are natural alternative hosts. CotAV-resistant cotton genotypes, as BJA, 592, NU 16 , have been identified (5). Genome sequencing of CotAV indicated that it is very closely related to the Cotton leafroll dwarf virus, also an aphid borne polerovirus $(6,7)$.

Ref.: (1) Costa, A.S. \& Sauer, H.F.G. Bragantia 13: 237. 1954; (2) Costa, A.S. Phytopathol.Zeit. 28: 167. 1956; (3) Costa A.S. Phytopath. Zeit. 65: 219. 1969 (4) Freire, E.C. et al. IPEAL (71/74). 1974; (5) Costa, A.S. et al. Summa Phytopathol. 7: 6. 1981; (6) Andrade, R.R.S. et al. Anais do $9^{\circ}$ Cong.Bras.Algodão. 2013; (7) Fausto, A.K.S. et al. Virus Review \& Res. 21: 116. 2016.

\section{Cotton leafroll dwarf virus (CLRDV)}

\section{Cotton vein mosaic virus (CotVMV)}

Vein mosaic of cotton was known since 1930' in the state of São Paulo, a disease characterized by vein mosaic, associated with the down curving of the leaf margins. In some cotton cultivars, leaves may become bluish. It was demonstrated to be aphid-borne and the causal virus known as CotVMV. A severe form of vein mosaic was known as type Ribeirão Preto. Cotton research group from Instituto Agronomico de Campinas developed resistant varieties (1, 2). After 1990's cotton culture advanced to Central Brazil, especially in the state of Mato Grosso, where a high incidence of the so called "mal azul" (blue disease) occurred, mostly in varieties introduced from USA. It was assumed that it was an epidemy of CotVMV because these introduced types were highly susceptible to it $(3,4)$. Molecular works developed with virus recovered from cotton plants affected by "mal azul", using specific primers for luteoviruses, amplified genome fragments with ca. $90 \%$ of similarity with coat protein gene of Chickpea stunt disease associated enamovirus (CpSDaV) (5). Sequence analysis suggested that this cotton virus could be a new polerovirus, and the name Cotton leafroll dwarf virus- CLRDV has been suggested (6). This virus was found in cotton plants from several Brazilian states as São Paulo, Paraná, Goiás, Federal District, and these isolates revealed little variability (7). Capsicum sp. was infected by this cotton virus when mass aphid inoculated. Two isolates of this virus from Goiás and Mato Grosso were able to break resistance, and had their genomes sequenced (8).

Ref.: (1) Costa, A.S. \& Forster, R. Bol.Tecn.IAC 51. 1938; (2) Costa, A.S. \& Carvalho, A.M.B. Cultura e Adubação do algodoeiro, Inst.Bras. Potassa p.433.. 1965; (3) Andrade, D.F.P. \& Lamas, F.M.. Fitopatol. bras. 25: 446. 2000; (4) Takimoto, J.K. et al.,. Fitopatol. Bras. 28 (supl.) 28: 254. 2003; (5) Corrêa, L.R. et al. Arch.Virol. 150:1357. 2005; (6) Franca, T.S. et al. Virus Rev\&Res 11 (supl): 192. 2006. (7) Silva, T.F. et al. Virology Journal 5: 123. 2008; (8) Silva, A.K. et al. Arch. Virology 160: 1371, 2015.

Begomovirus

Infectious chlorosis of malavaceae complex" (ICNC)

In the state of São Paulo, where first cases of cotton infection by begomovirus were registered, the pathogen was identified as ICNC, transmitted by whitefly Bemisia tabaci. Though in low incidence, the disease was well disseminated, but without economic importance. Infected plants exhibit yellow mosaic and blistering of leaves, stunting, partial or total sterility, and the condition has been referred to as "pseudo mosaic". Spontaneous vegetation growing nearby cotton cultures, as Sida spp. harbor the virus, which is transmitted to cotton by whiteflies, however whiteflies was unable to transmit ICMC from cotton to cotton. This viral disease was first described in the state of São Paulo, but seems to occur wherever cotton is cultivated (1-5).

Ref.: (1) Bitancourt, A.A. Conf. Nac.Algodoeira, SP, p.15. 1935; (2) Costa, A.S. Bol.Teen. IAC 37. 1937; (3) Costa, A.S. \& Forster, R. Rev. Agricultura 12: 453. 1937; (4) Orlando, A. \& Silberschmidt, K. Arq. Inst.Biol. 16: 133. 1945; (5) Costa, A.S. Bragantia 13: XXIII. 1954. Cotton chlorotic spot virus (CCSV)

A begomovirus was identified infecting cotton and causing chlorotic spots, internerval chlorosis and distortion on leaves, in the state of Paraíba. Molecular characterization indicated that the virus seems to be a new species and named CCSV (1).

Ref.: (1) Almeida, M.M.S. et al. Genome Announc. 1(6). e0066113-e00661-13. 2013.

\section{*Guibourtia hymenifolia (Moric.) J.Léonard Fabaceae}

Orthotospovirus

Groundnut ringspot virus (GRSV)

GRSV was detected in G. hymenifolia by immunoassay in Brasília, DF (1).

Ref.: (1) Santos, F.M.B. et al. Trop.Plt. Pathol. 41 (supl.): CDRom. 2016.

H

\section{*Hedera canariensis (Kirchn.) Bean (Ivy) Araliaceae Cilevirus \\ Cilevirus unidentified}

Green spots on senescent leaves were observed in ivy growing in the campus of the Universidade de São Paulo (ESALQ), Piracicaba, SP, associated with infestation by the tenuipalpid mite Brevipalpus phoenicis s.l., Electron microscopy of tissues from these green spots demonstrated cytopathic effects characteristic of cileviruses, which is still unidentified (1).

Ref.: (1) Kitajima, E.W. et al. Scientia Agric. 67: 348. 2010

\section{*Helianthus annuus L. (Sunflower) Asteraceae}

Ilarvirus

Tobacco streak virus (TSV)

Infection of sunflower by TSV results in growth paralysis. Young leaves become chlorotic, bent downwards e malformed; lower leaves may show vein clearing and necrosis; tip blight may occur. Such 
disease was reported in the state of São Paulo. Identification of TSV was made by biological assays (1).

Ref.:(1) Costa, A.S. \& Costa, C.L. Rev.Soc.Bras.Fitopat. 5: 61.1972. Potyvirus

Bidens mosaic virus (BiMV)

Sunflower plants showing systemic necrosis on their leaves were observed in the state of São Paulo, and demonstrated to be caused by BiMV using biological assays and electron microscopy (1).

Ref.: Costa, A.S. \& Kitajima, E.W. Supl.Agri.O Est.S.Paulo. nov. 1966.

Alphaecrovirus

Tobacco necrosis virus (TNV)

TNV was recovered from roots of asymptomatic sunflower plants, maintained under greenhouse conditions in the Instituto de Agronômico, Campinas, SP (1).

Ref.: (1) Costa, A.S. \& Carvalho, A.M.B. Bragantia 19: CXLVII. 1960.

\section{*Helichrysum sp. Mill. (Helychrisum) Asteraceae}

Potexvirus

Althernanthera mosaic virus (AltMV)

Serological assays identified AltMV as the causal agent of mosaic in helychrisum, collected at São José do Rio Preto, SP (1).

Ref.: (1) Alexandre, M.A.V. et al. Trop.Plt Pathol. 33 (supl): S231. 2008 .

\section{*Heliconia stricta Huber. (Heliconia) Heliconiaceae \\ Potyvirus \\ Potyvirus unidentified}

Heliconia exhibiting chlorotic spots on their leaves were found in a commercial plantation at Registro, SP. A still unidentified potyvirus was found by RT-PCR associated with the disease (1).

Ref.: (1) Harakava, R. et al. Summa Phytopathol. 39 supl CDRom. 2013.

\section{*Hemerocallis sp. (Daylily) Hemerocallidaceae \\ Tobamovirus}

\section{Tomato mosaic virus (ToMV)}

A tobamovirus, identified as ToMV by molecular assays, was detected in daylily plants sampled in the state of São Paulo with mosaic symptoms $(1,2)$.

Ref.: (1) Duarte, L.M.L. et al. Virus Rev.\& Res. 11 (supl.): 191. 2006; (2) Duarte, L.M.L. et al. Summa Phytopathol. 33: 409. 2008

\section{*Heliotropium indicum L. (Indian heliotrope) Boraginaceae Orthotospovirus \\ Zucchini lethal chlorosis virus (ZLCV) \\ Cucumovirus}

Cucumber mosaic virus (CMV)

Potyvirus

\section{Zucchini yellow mosaic virus (ZYMV)}

During a survey on viruses infecting weeds around commercial cucurbit fields in the state of Tocantins, ZLCV and ZYMV were found in $H$. indicum in the municipality of Formoso do Araguaia. CMV was the only virus found in this plant in Figueirópolis (1).

Ref.: (1) Aguiar, R.W.S. et al. Planta Daninha 36: e018171593. 2018.

\section{*Herissantia crispa (l.) Brizicky (Bladdermallow) Malvaceae Begomovirus \\ Begomovirus unidentified}

An unidentified begomovirus was found causing mosaic in bladdermallow in the state of Alagoas (1).

Ref: (1) Assunção, L.P. et al. Planta Daninha 24: 239. 2006.

\section{*Hevea brasiliensis Mull. Arg. (Rubber tree) Euphorbiaceae Carlavirus \\ Carlavirus unidentified}

Mosaic, internerval chlorosis and smaller size of leaf blade were noticed in rubber trees produced at Embrapa Amazonia Ocidental, Manaus, AM, and kept at Embrapa Biotecnologia, Brasília, DF. Carlavirus-like particles were found in leaf extracts and tissue sections of these plants. However, no mechanical transmission was achieved to indicator plants. This unidentified carlavirus has yet to be characterized (1).

Ref.: (1) Gama, M.I.C.S. et al. Fitopatol.bras. 8: 621. 1983.

*Hibiscus rosa-sinensis L (Hibiscus), H. schizopetalus (Mast.) Hook.f. (Japanese lantern), H. syriacus L (Rose of Sharon) Malvaceae

Dichorhavirus

Clerodendrum chlorotic spot virus (CICSV)

Chlorotic spots, with irregular borders, distinct from those smaller, caused by HCRSV, were noticed on green leaves of hibiscus in Campos de Goytacazes, RJ, Campinas and Piracicaba, SP, associated with Brevipalpus mite infestation. Electron microscopic analysis of tissues from these lesions revealed cell alterations typical of those caused by dichorhaviruses. Mite transmission experiments with ClCSV using infected Clerodendrum $x$ speciosum plants as source of inoculum, reproduced the same symptoms in uninfected hibiscus (1). In a sample collected from Campos de Goytacazes, RJ, which were double infected by ClCSV and HGSV, some parenchymal cells were observed double infected by these two viruses, a fact considered demonstrative that dichorha- and cileviruses are completely distinct. ClCSV-infected hibiscus plants were found in Manaus, AM (3).

Ref.:(1) Kitajima, E.W. et al. Scientia Agricola 67: 348. 2010; (2) Kitajima, E.W. et al. Summa Phytopathol. 27: 105. 2001 (3) Rodrigues, J.C.V. et al. Trop.Plt. Pathol. 33:12. 2008.

Nucleorhabdovirus

\section{Eggplant mottled dwarf virus (EMDV)}

A nucleorhabdovirus was found by electron microscopy, coinfecting with phytoplasma, hibiscus plants with witches' broom symptoms in the state of São Paulo. This nucleorhabdovirus was tentatively identified as EMDV, based on similar case abroad (1).

Ref.: (1) Caner, J. et al. Summa Phytopathol. 3: 155. 1977.

Nepovirus

Hibiscus latent ringspot virus (HLRSV)

During researches undertaken to characterize a Brazilian isolate of HCRSV, several samples were co-infected by HLRSV, as deduced by serological analysis. Further assays demonstrated that both viruses were co-transmitted by chrysomelids, probably due to a transcapsidation of the HLRSV genome by coat protein of HCRSV (1).

Ref.: (1) Araújo, S. et al. Fitopatol.bras. 14: 124. 1989.

Cilevirus

Hibiscus green spot virus (HGSV)

Several Hibiscus species as H. rosa-sinensis, H. syriacus, $H$. schizopetalus, have been found with green spots or ringspots, sometimes brown to reddish-brown spots on their leaves, associated with infestation by tenuipalpid mite Brevipalpus phoenicis s.l. Electron microscopy of tissues from such lesions revealed the occurrence of cytopathic effects typical of cileviruses $(1,2)$. The unidentified causal virus was named HGSV and it was shown that it was mite transmissible to plants as kenaf (3). HGSV have been found disseminated in Brazil, being registered in the states of São Paulo, Rio de Janeiro, Minas Gerais, Amazonas and Distrito Federal. It was also observed abroad in Bolivia, Panama and Cuba $(4,5)$. It probably is 
distinct from another green spot causing virus, described in Hawaii which is similar to cileviruses, but has a tripartite genome, being designated HGSV 2, belonging to the genus Higrevirus (6).

Ref.: (1) Kitajima, E.W. et al. Abst.Scandem 88: 63. 1999; (2) Kitajima, E.W. et al. Expt.Appl.Acarology 30: 135. 2003; (3) Ferreira, P.T.O. et al. Summa Phytopathol. 30: 68. 2004; (4) Kitajima, E.W. et al. Virus Rev.\& Res. 9: 248. 2004.(5) Rodrigues, J.C.V. et al. Trop. Plant Pathol. 33:12. 2008; (6) Melzer, M. J. et al Phytopathology 102:122, 2012.

\section{Betacarmovirus}

\section{Hibiscus chlorotic ringspot virus (HCRSV)}

First description of the occurrence of HCRSV was made in Brasília, $\mathrm{DF}$, in hibiscus plants showing conspicuous small chlorotic spots on leaves. Identification of the virus was based on biological assays and serology. The virus was purified from mechanically infected kenaf plants and a specific antiserum was produced. Some molecular information about the genome RNA and capsidal protein were obtained. HCRSV was successfully transmitted by the chrysomelid beetle Diabrotica speciosa (1). A serological survey indicated that practically all hibiscus samples from several regions of Brazil were infected by HCRSV, sometimes even being asymptomatic. Clonal propagation must be the cause of such geographic dispersion (2).

Ref.: (1) Araújo, S. et al. Fitopatol.bras. 13: 144. 1988; (2) 14: 124. 1989

\section{Tobamovirus}

\section{Hibiscus latent virus Fort Pierce (HLV-FP)}

Hibiscus plants showing chlorotic spots were found in a commercial nursery in Limeira, SP. Initial suspicion of infection by HCRSV was discarted by serology, and instead tobamovirus-like particles were found in leaf extracts examined by electron microscopy. Further biological, serological and molecular assays indicated that this tobamovirus was an isolate of HLV-FP. The virus was purified and a specific antiserum was produced. Further serological survey indicated that HLV-FP was present in low incidence in hibiscus growing in parks and gardens in the region of Piracicaba and Águas de São Pedro, SP (1). An infectious clone of this HLV-FP was produced after its genome has been completely sequenced (2).

Ref.:(1) Alves, P.M. Summa Phytopathol. 41(supl): res.39. 2015; (2) Gao, R. et al. Virus Genes 51:1. 2016.

Caulimovirus

\section{Caulimovirus unidentified}

First observed by electron microscopy, a caulimovirus yet to be characterized was found, co-infecting hibiscus with HGSV (1).

Ref.: (1) Kitajima, E.W. et al. Abst.Scandem 88: 63. 1999.

Begomovirus

\section{Begomovirus unidentified}

An unidentified begomovirus was detected by molecular means in hibiscus showing golden mosaic symptoms in the state of Rio de Janeiro (1).

Ref (1) Almeida, M.M.S. et al. Virus Rev.\&Res 14(supl) 225. 2009.

Hibiscus golden mosaic virus (HGMV)

A begomovirus, distinct from others known previously based on its bipartite genome sequence, was found infecting hibiscus with mosaic symptoms in Igarapé-Mirim, PA (1).

Ref.: (1) Quadros, A.F.F. et al. Res.29 CBVirol. 2018.

\section{*Hippeastrum sp. (Amaryllis) Amarilidaceae Orthotospovirus Groundnut ringspot virus (GRSV)}

GRSV has been detected in amaryllis, showing chlorotic spots on leaves, by biological and molecular assays and electron microscopy in the state of São Paulo (1).

Ref.: (1) Duarte, L.M.L. Virus Rev. \& Res. 6: 50. 2001

\section{Potyvirus}

Bean yellow mosaic virus (BYMV)

Infection of amaryllis by BYMV was reported in the state of São Paulo, without additional details (1).

Ref. (1) Alexandre, M.A.V. et al. Rev.Bras.Hort.Ornam. 16: 95.2010. Hippeastrum mosaic virus (HiMV)

A case of necrotic mosaic in amaryllis caused by HiMV was reported in the state of São Paulo $(1,2)$.

Ref. (1) Duarte, L.M.L. et al. Trop.Plt Pathol 34(supl): S274. 2009; (2)

Alexandre, M.A.V. et al. Journal of Plant Pathology 93: 643. 2011.

\section{*Hordeum vulgare L. (Barley) Poaceae}

Hordeivirus

\section{Barley stripe mosaic virus (BSMV)}

A rodlike virus was found infecting barley cv. 'Puebla' introduced from Mexico, and causing stripe mosaic on leaves in an experimental field of Embrapa Cerrado, Planaltina, DF. Further assays identified the causal virus as BSMV which is seed transmitted. The field was destroyed after the confirmation of the presence of BSMV, a quarantine pathogen (1)

Ref.: (1) Anjos, J.R.N. et al. Fitopatol. bras.12: 278. 1987.

\section{*Hyacinthus orientalis L. (Hyacinth) Asparagaceae Potyvirus Hyacinth mosaic virus (HyaMV)}

Hyacynth plant showing mosaic symptoms were found in a flower market in São Paulo, SP. Suspicion that the mosaic was due to a viral infection was confirmed by ELISA and RT-PCR assays. An amplified fragment of the CP was sequenced revealing a high identity $(96 \%)$ with that of HyaMV (1).

Ref.: (1) Alexandre, M.A.V. et. Al. Trop.Plt. Pathol. 42: 51. 2017.

\section{*Hydrangea macrophylla L. (Hydrangea) Hydrangeaceae Potexvirus \\ Hydrangea ringspot virus (HRSV)}

HRSV was detected in hydrange plants found in Mogi das Cruzes, SP, showing ringspot symptoms on leaves. Further tests identified the causal agent of the disease as an isolate of HRSV (1).

Ref: (1) Dória, K.M.A.B.V.S. et al. Summa Phytopathol. 37: 125. 2011.

*Hypochaeris brasiliensis (Less.) Griseb. (Brazilian cat's ear) Asteraceae

Potyvirus

Lettuce mosaic virus (LMV)

H. brasiliensis is a common weed nearby soybean plantations. A potyvirus was found infecting this plant which was identified as an isolate of LMV (1).

Ref.: (1) Silva, J.A. et al. New Disease Rptr.38: 23. 2018.

\section{*Hyptis sp. Lamiaceae}

Begomovirus

Hyptis rugose mosaic virus 1 and 2 (HyRMV1, 2)

Two distinct begomoviruses were identified naturally infecting Hyptis sp. plants in the state of Alagoas, possibly new species. No further information availabe (1).

Ref.: (1) Nascimento, L.D. et al. Trop.Plt.Pathol. 38(supl.): 195. 2013.

I

*Impatiens balsamina L., I. walleriana Hook f. (=I. sultani), I. hawkeri W.Bull (Garden balsam, Touch-me-not) Balsaminaceae Cucumovirus 


\section{Cucumber mosaic virus (CMV)}

Impatiens balsamina (1) in Lavras, MG and I. walleriana em Atibaia, SP (2) were found infected by CMV.

Ref.: (1) Boari, A.J. et al. Fitopatol.bras. 21: 422. 1996; (2) Duarte, L.M.L. Fitopatol.bras. 21: 424. 1996.

Potyvirus

Potyvirus unidentified

Mottling and floral variegation were observed in I. balsamina and I. sultani plants in a residential garden in Brasília, DF. A mechanically transmissible potyvirus was recovered (1). A similar case was recorded in the state of Paraná (2).

Ref.: (1) Cupertino, F.P. et al. Fitopatol.bras. 15: 127. 1990; (2) Lima, M.L.R.Z.C. et al.Rev.Setor Cien.Agr. 2: 169. 1980.

Tobamovirus

Tomato mosaic virus (ToMV)

A tobamovirus, identified as ToMV was found causing mosaic and blistering on leaves of Impatiens hawkeri in São Paulo, SP (1). Identification of this isolate of ToMV was made based on molecular assays (nucleotide sequence of the coat protein) $(2,3)$.

Ref.: (1) Rivas, E.B. . et al. Plant Dis. 84: 707. 2000; (2) Duarte, LML et al. Virus Rev\&Res. 11 (aupl): 191. 2006; (3) Duarte, L.M.L. et al. Summa Phytopathol. 33:409. 2008.

\section{*Ipomea batatas (L.) Lam. (Sweet potato) Convulvulaceae} Carlavirus

Sweet potato C6 virus (SP6CV)

The carlavirus SP6CV was detected by NMC-ELISA in sweet potato sampled in the state of São Paulo (1).

Ref.: (1) Silva, M.G. et al. Res.420, 50o Cong.Bras.Fitopat., 2017.

Carlavirus

Sweet potato chlorotic fleck virus (SPCFV)

Crinivirus

Sweet potato chlorotic stunt virus (SPCSV)

Potyvirus

Sweet potato latent virus (SPLV)

Sweet potato mild speckling virus (SPMSV)

Sweet potato virus $G$ (SPVG)

An extensive survey made on the sweet potato germplasm collection kept at Embrapa Hortaliças, Brasília, DF, with sampling of more than 100 genotypes, several previously unreported viruses were found by NCM-Elisa besides SPFMV, as listed above. However, no further biological assays were performed.

Ref.: (1) Fernandes, F.R. et al. Trop.Plant Pathol. 37 (supl.) CDRom. 2012.

Ipomovirus

Sweet potato mild mottle virus (SPMMV)

SPMMV has been detected in serological surveys made in samples from the states of Pernamcuco and Paraíba, without further information (1).

Ref.: (1) Souza, C.A. et al. Trop.Plt.Pathol. 38 (supl): 754-2. 2013.

Potyvirus

Sweet potato feathery mottle virus (SPFMV)

This was the first virus registered infecting sweet potato in Brazil, being well disseminated. Infected plants show varied degree of mosaic, depending on cultivars. SPFMV was identified based on its biological and morphological characteristics. Initial reports were made in the states of São Paulo and Rio de Janeiro, and later, Pernambuco, Paraíba, Rio Grande do Sul $(1-3,6,7,9)$. The use of vegetative propagation and aphid dissemination are responsible for the high incidence and rate of spreading, causing a condition known as degenerescence, with significative impact on the yield. Use of virus-free plants obtained by meristem tissue culture is being effective as control measure $(4,5)$, despite a high rate of re-infection under field conditions (8).
Ref.: (1) Costa, A.S. et al. Fitopatologia (Lima) 8: 7. 1973; (2) Kitajima, E.W. \& Costa, A.S. Bragantia 33: XLV. 1974; (3) Kitajima, E.W. et al. Fitopatologia (Lima) 10: 57. 1975; (4) Carvalho, A.C.P.P. et al. Hort.Bras. 6: 49. 1988; (5) Gama, M.I.C.S. Fitopatol.bras.13: 283. 1988; (6) Gueiros Jr., F. et al. Fitopatol. bras. 20: 308.1995; (7 ) Pozzer, L. et al. Fitopatol.bras. 20: 65. 1995; (8) 464. 1995; (9) Kroth, L.L.. \& Daniels, J. Fitopatol.bras. 27: S 206. 2002.

Cavemovirus

Sweet potato collusive virus (SPCV)

An isolate of SPCV was found during a survey made on the germplasm collection of Embrapa Hortaliças, Brasília, DF by NMCELISA (1). This virus was also found by NMV-ELISA in sweet potato sampled in the state of São Paulo (2).

Ref.: (1) Fernandes, F.R. et al. Trop.Plant Pathol. 37 (supl.) CDRom. 2012; (2) Silva, M.G. et al. Res.420, 50o Cong.Bras.Fitopat., 2017.

Begomovirus

Sweet potato golden vein associated virus (SPGVaV)

Sweet potato mosaic associated virus (SPMaV)

During a survey in the sweet potato germplasm bank of the Embrapa Hortaliças, in Brasília, DF, two possible new begomovirus was found by RCA/RFLP, respectively SPGVaV and SPMaV (1). SPGVaV was also found in a survey using molecular tools, carried out in the Active Germplasm Bank of sweet potato of the Universidade Federal Rural de Pernambuco, Recife, PE (2).

Ref.: (1) Paprotka, T. et al. Virus Res. 149: 224, 2010; (2) Souza, C.D.A. et al. Trop.Plt.Pathol. 38 (supl.): CDRom res. 604-2. 2013

Sweet potato leaf curl virus São Paulo virus (SPLCV-SP)

Sweet potato showing leaf curl symptoms from several parts of Brazilian North and Northeast regions were analysed using molecular tools at Embrapa Hortaliças, Brasília, DF $(1,4)$. SPLCV was later detected in the states of São Paulo (2) and Pernambuco (3). A possible isolate of SPLCV was found infecting sweet potato causing vein chlorosis and necrosis in Alvares Machado, SP. Molecular assays revealed that there is a $12,4 \%$ difference in nucleotide sequence compared to the standard isolate. It may, thus, represent a new begomovirus species (5). SPLCV was also detected in sweet potato producing fields in Pelotas, RS, by molecular assays (6).

Ref: (1) Albuquerque, L.C. et al. Virus Rev.\&Res. 14(supl): 223. 2009; (2) Albuquerque, L.C. et al. Arch.Virol. 156; 1291. 2011; (3) Souza, C.D.A. et al. Trop.Plt.Pathol. 38 supl.604-2. 2013; (4) Souza, C.A. et al. Trop.Plant Pathol. 41 (supl.) 2016; (5) Albuquerque, L.C. et al. Arch.Virol. 156: 1291. 2011; (6) Maich, S.L.S.P. et al. Res. 29 Cong.Bras.Virol. 2018

\section{Mastrevirus}

Sweet potato symptomless virus 1 (SpSV/1)

A survey made on 100 sweet potato samples, collected in different producing areas in Brazil, by RT-PCR, detected SpSV/1. About half of the positive cases came from Northeast, being also detected in South, Southeast and Center-West regions. One of the isolates presented 99\% sequence identity with that described in Taiwan. Transmission was confirmed by grafting (1).

Ref.: (1) Souza, C.A. et al. Plant Dis.102:b2052. 2018.

\section{$\mathbf{J}$}

\section{*Justicia sp. (Shrimp plant, Water-willow) Acanthaceae Cucumovirus \\ Cucumber mosaic virus (CMV)}

Shrimp plant was found in Horto Municipal, Fortaleza, CE, exhibiting concentric rings and spots on leaves. Biological and serological assays identified CMV as the causal agent of this disease. Ref.: (1) Araripe, D.F.A. \& Lima, J.A.A. Fitopatol.bras 18: 275. 1993. 
K

*Kalanchoë blossfeldiana Poelln. (Flaming katy) Crassulaceae Nucleorhabdovirus

Sonchus yellow net virus (SYNV)

A Nucleorhabdovirus was found in K. blossfeldiana plants introduced from the Netherlands. Infected plants showed chlorotic spots. Detection of this virus associated to the symptoms was made by electron microscopy and serology confirmed its identity as SYNV. No mechanical transmission was achieved. This same virus was detected in another crassulaceae plant, Cotyledon orbiculata, and managed to be transmitted to $K$. blossfeldiana, resulting in systemic infection (1). Ref.: (1) Duarte, L.M.L. et al. Summa Phytopathol. 31: 63. 2005.

\section{*Kalanchoë sp. (Kalanchoe) Crassulaceae}

Potyvirus

\section{Potyvirus unidentified}

Potyvirus-like particles were found in extracts of Kalanchoë $s p$. showing mosaic and blistering, collected at Teresópolis, RJ. The causal agent was mechanically transmitted to the same host species and to Chenopodium quinoa, causing local lesions. This virus was purified and a specific antiserum produced. Heterologous reaction was obtained with potyviruses PVY, CABMV e BCMV but this virus remains unidentified (1).

Ref.: (1) Braz, A.S.K. et al. Fitopatol. Bras. 21: 422.1996.

$\mathbf{L}$

\section{*Lactuca sativa L. (Lettuce) Asteraceae Ophiovirus \\ Mirafiori lettuce big-vein virus (MiLV) \\ Varicosavirus \\ Lettuce big-vein associated virus (LBVaV)}

These two viruses are involved in the lettuce big-vein syndrome, characterized by thickening of leaf veins, reducing the commercial value of the product; in some varieties as the American, heads are not formed. It is a typical winter disease, when under milder climate, symptons become evident. Transmission is made by soil chytrid fungus Olpidium brassicae (1). It was found in the green belt of São Paulo, SP (1), as well as in Campinas e Baurú, SP (2). Serology, molecular assay and electron microscopy identified these viruses (1). It was also detected in the state of Paraná (2).

Ref.: (1) Lot, H. Phytopathology 92: 288, 2002; (2) Colariccio, A. et al. Fitopatol.bras. 27: S201. 2002; (2) Sanches, M.M et al. Summa Phytopathologica, 33:378. 2007. (3) Lima No., V.C. Summa Phytopathol. 30: 83. 2004.

Nucleorhabdovirus

\section{Nucleorhabdovirus unidentified}

Electron microscopy detected a nucleorhabdovirus yet uncharacterized, in lettuce samples with chlorotic spots and vein clearing, collected in Federal District and Teresópolis, RJ $(1,2)$.

Ref.: Kitajima, E.W., \& Marinho, V.L.A. Fitopatol.bras. 7: 534. 1982; (2) Kitajima, E.W. et al. Fitopatol.bras. 9: 607. 1984.

Orthotospovirus

\section{Groundnut ringspot virus (GRSV)}

Tomato chlorotic spot virus (TCSV)

Tomato spotted wilt virus (TSWV)

Leaf deformation, wrinkling, ringspots and systemic necrosis symptoms with varied incidence in commercial lettuce plantations are caused by Orthotospoviruses. Originally such a disease was reported in the state of São Paulo $(1,2)$, with later reports in the states of Pernambuco (3) and Rio Grande do Sul (5). In the state of São Paulo TCSV (4) and GRSV (8) were identified infecting lettuce. In a survey made in the São Francisco valley, state of Pernambuco, a high incidence of GRSV was observed (6), and also in hydroponic cultures in the state of São Paulo (7). Some resistant genotypes have been found $(9,11)$. TSWV was detected in lettuce in the state of Alagoas (10). Surveys on lettuce fields in the state of Tocantins found plants infected by GRSV (12), as well as in hydroponic cultures in the state of Pará (13).

Ref.: (1) Costa, A.S. \& Forster, R. Bragantia 2: 83. 1942; (2) Chagas, C.M. O Biológico 36: 256. 1970; (3) Moraes, G.J. et al. Hortic.Bras. 6: 24. 1988; (4) Colariccio, A. et al., Fitopatol.bras. 20: 347. 1995; (5) Daniels, J. \& Canci, P. Fitopatol. Bras. 20: 301. 1995; (6) de Ávila, A.C. et al. Fitopatol.bras. 21: 503. 1996; (7) Yuki, V.A. et al. Summa Phytopathol. 22: 57. 1996; (8) Chaves, A.C.R. et al. Fitopatol. Bras. 25: 439. 2000; (9) Silva, N. \& Pavan, M.A. Fitopatol.bras. 26: 511. 2001; (10) Lima, G.S.A. et al. Virus Rev. \& Res. 6: 157. 2001; (11) Yamazaki, E. et al., Fitopatol.bras. 26: 527. 2001;(12) Lima No., A.F. et al. Fitopatol.bras. 31(supl):S347. 2006; (13) Hayashi, E.A. et al. Trop.Plt.Pathol. 38 (supl): 455-1. 2013.

Sequivirus

Lettuce mottle virus (LeMoV)

LeMoV was first identified in lettuce plantations in Brasília, DF. Infected plants show symptoms, essentially similar to those caused by LMV, and the causal agent is mechanically transmissible, with practically the same host range. Suspicion of an infection by a virus distinct from LMV was raised when the causal virus was not aphid transmitted. Further assays demonstrated that this virus is isometric, and named $\operatorname{LMoV}(1,3)$. It was partially purified and an antiserum obtained (2). Besides DF, LMoV was also detected in Caxias, RS, Rio Novo, SC and Campinas, SP (1). It is a possible member of the family Sequiviridae and genus Sequivirus, related to ao Dandelion yellow mosaic sequivirus (DaYMV) (4,5). A survey made in the state of São Paulo indicated that $\mathrm{LMoV}$ is quite widespread (6). LMoV was found naturally infecting Galinsoga parviflora (7). LMoV was also detected in the state of Minas Gerais (8).

Ref.: (1) Marinho,V.L.A. \& Kitajima, E.W. Fitopatol.bras. 11: 923. 1986; (2) Marinho, V.L.A. et al. Fitopatol.bras. 11: 937. 1982; (3) Kitajima,E.W. \& Pavan, M.A. Lettuce mottle virus. In Davis, R.M. et al. (eds.). Compendium of lettuce diseases. St.Paul, APS Press. pp.44. 1997; (4) Chaves, A.L.R. et al. Fitopatol.bras. 26: 514. 2001; (5) Jadão, A.S. et al., Arch. Virol. 152:999-1007, 2007. (6) De Marchi et al. Summa Phytopathol 38:245-247, 2012. (7) De Marchi, B.R. et al. Summa Phytopathol. 38: 245. 2012; (8) Lucas, M.A. et al. Trop.Plt. Pathol. 38(supl.): 200. 2013.

Tymovirus

Tymovirus unidentified

A yet to the characterized tymovirus was found infecting lettuce in Piedade, SP. This tymovirus isolate may be related to the Eggplant mosaic tymovirus (EMV) and Turnip yellow mosaic tymovirus (TYMV) (1).

Ref.: (1) Colariccio, A. et al Summa Phytopathol 36 (supl): \#205 CDRom. 2010.

\section{Cucumovirus}

\section{Cucumber mosaic virus (CMV)}

Infection of lettuce by CMV was reported in the state of São Paulo, and considered of very rare occurrence (1).

Ref.: (1) Costa, A.S. Summa Phytopathol. 9: 39. 1983.

Potyvirus

\section{Bidens mosaic virus (BiMV)}

BiMV was found naturally infecting lettuce and causing mosaic in S.Manoel, SP (1). Cases of BiMV infection of lettuce seem rare, and it was also registered in Campinas and Baurú, SP, in places invasive plants as Bidens pilosa and Galinsoga parviflora, natural hosts of BiMV, are common (2). 
Ref. (1) Suzuki, G.S. et al. Summa Phytopathol. 35:231. 2009; (2) Sanches, M.M. et al. Summa Phytopathol. 36: 347. 2010.

Lettuce mosaic virus (LMV)

LMV is the most common virus in lettuce crops and may cause yield losses in highly susceptible varieties. Infection results in symptoms as mosaic, blistering and malformed heads. This virus is seed-borne and spread in the field by aphids, and mechanically transmissible to a wide host range. First report in Brazil was made in the 1940's in São Paulo, SP (1). It is present everywhere lettuce is grown, but has been formally described in the states of Federal District (3), Rio de Janeiro (4), Paraná (5), Rio Grande do Sul (6), Sergipe (12), Mato Grosso do Sul (13). Resistant varieties have been produced (2). LMV is also present in hydroponic cultures (7). LMV is commonly introduced in commercial field by contaminated seeds and then spread by aphids. There are virus isolates as LMV-Most able to break resistance in lettuce produced by genes $\mathrm{mol}^{1}$ e $\mathrm{mol}^{2}$ (8). Sonchus spp., Erigeron spp. and Galinsoga parviflora were found naturally infected by LMV and may serve as source of inoculum (9-11).

Ref.: (1) Kramer et al. O Biológico 11: 121. 1945; (2) Nagai, H. \& Costa, A.S. Arq.Inst.Biol. 38: 95. 1971; (3) Costa, C.L. et al. Fitopatologia (Lima) 9: 49. 1974; (4) Robbs, C.F. \& Viegas, E.C. Guia de Controle às pragas e doenças das Cult.Econ. do Estado, Sec. Agric.Abast., RJ. 84p. 1978; (5) Lima, M.L.R.Z.C. et al. Fitopatol. bras. 9: 403. 1984; (6) Daniels, J. \& Canci, P. Fitopatol.bras. 20: 301. 1995; (7) Cossa, A.C. et al. Fitopatol.bras. 27: S202. 2002; (8) KrauseSakate, R. et al. Phytopathology 92: 563. 2002; (9) Chaves, A.L.R et al., Summa Phytopathol. 29: 61. 2003; (10) Fitopatol.Bras.28: 207. 2003; (11) Sanches, M.M. et al. Summa Phytopathol 36: 346. 2010; (12) Floresta, L.V. et al. Fitopatol.bras. 31 (supl) S322. 2006; (13) Stangarlin, O.S. et al. 50 CBFito. res.406. 2017.

\section{Turnip mosaic virus (TuMV)}

TuMV was detected in lettuce plants with mosaic symptoms collected in the state of São Paulo. Identification was based on biological, serological and molecular assays (1).

Ref.: (1) Ribeiro Jr., M.R. et al. J.Plant Pathol.100: 189. 2018.

\section{*Lens culinaria L. (Lentil) Fabaceae \\ Orthotospovirus}

Tomato spotted wilt virus (TSWV)

Natural infection of lentil by TSW was reported in Brasília, DF, resulting in pod necrosis (1).

Ref.: (1) Fonseca, M.E.N. et al. Plant Dis. 79: 320. 1995.

Potyvirus

\section{Bean common mosaic virus (BCMV)}

Lentil with mosaic symptoms, from the state of Rio Grande do Sul, was found infected by BCMV (1).

Ref.: (1) Costa, C.L. et al. Fitopatologia (Lima) 10: 52.1975.

\section{*Leonurus sibiricus L. (Chinese motherwort, Honeyweed) Lamiaceae \\ Begomovirus \\ Tomato yellow spot virus (ToYSV)}

Infection by begomovirus, now identified as ToYSV, was described in 1960 's in several tomato growing regions of the state of São Paulo. An intense yellow mosaic characterizes the symptom, and the causal virus was transmitted by the whitefly Bemisia tabaci. It was mechanically transmitted to honeyweed besides tobacco and N. glutinosa. The virus was considered related to, but distinct from Infectious chlorosis of malvaceae complex and EuYMV (1,2). Molecular assays made on tomato plants showing yellow mosaic, similar to previously described, collected in the state of Paraná, identified the causal virus as ToYSV (3)

Ref.: (1) Costa, A.S. \& Carvalho, A.M.B. Phytopathol.Zeit. 38: 129. 1960; (2) Flores, E. \& Silberschmidt, K. Phytopathol.Zeit. 43: 221. 1962; (3) Boiteux, L.S. et al. Trop Plt Pathol. 34 (supl): S266. 2009.

\section{*Ligustrum lucidum W.T. Aiton (Glossy privet); Ligustrum sinense Lour. (Japanese privet); Ligustrum japonicum Thunb. (wax-leaf privet) Oleaceae \\ Cilevirus \\ Ligustrum leprosis virus (LigLV)}

Chlorotic and ringspot symptoms on leaves of L. lucidum forming a living fence were observed in the campus of the Univ. Federal do Paraná, Curitiba, SP. These symptoms were similar to those described in Bella Vista, Argentina, and referred to as "lepra explosiva". Similar cases were also found in Águas de S.Pedro, Holambra, Monte Alegre do Sul e Piracicaba, SP, and in Brasília, DF, associated with Brevipalpus mite infestation. Electron microscopy of the tissues from these lesions revealed cytopathic effects of the type caused by cileviruses (1-6). Transmission from privet to privet by Brevipalpus phoenicis s.l. could be demonstrated $(2,5)$, as well as from privet to bean plants (4). Electron microscopy of leaf lesion of $L$. sinense sampled in B.Vista, Argentina, where this condition was first described, resulted in similar results obtained with Brazilian samples (7). The privet virus was tentatively named Ligustrum ringspot virus in Brazil, but due to priority reasons, it is being called Ligustrum leprosis virus (LigLV) (7).

Ref.: (1) Lima, M.L.R.Z.C. et al. Phytopathology 81: 1216. 1991; (2) Rodrigues, J.C.V. et al. Fitopatol. bras. 20:292. 1995; (3) Nogueira, N.L. et al. Fitopatol.bas. 29: S234. 2004; (4) Kitajima, E.W. et al. Expt.Appl.Acarol. 30: 135.2003; (5) Kitajima, E.W. et al. Summa Phytopathol 38 (supl.) CDRom 2012. (6) Kitajima, E.W. et al. Scientia Agricola 67: 348. 2010; (7) Kitajima, E.W. et al. Virus Rev \& Res.20 (supl.): 196. 2015.

\section{*Lilium sp. (Lily) Liliaceae \\ Cucumovirus \\ Cucumber mosaic virus (CMV)}

Seedlings of lily, produced commercially by micropropagation, showing chlorotic spots were demonstrated to be infected by CMV serogroup I. Identification was based on serological and molecular techniques (1). The same virus was recovered from cultivated lily plants from Atibaia and Holambra, SP (2).

Ref.: (1) Alexandre, M.A.V. et al. Fitopatol.bras. 26: 513. 2000. (2)

Jadão, A.S. et al. Trop.Plt Pathol. 33 (supl): S298. 2008

Potyvirus

\section{Bean yellow mosaic virus (BYMV)}

Field lily plants with mosaic symptoms, cultivated in the state of São Paulo were found infected by BYMV (1).

Ref. (1) Alexandre, M.A.V. et al. Rev.Bras.Hort.Ornam. 16: 95.2010. Tulip breaking virus (TBV)

Necrotic spots and mottling were observed on lily leaves, being commercially grown in Brasilia, DF. Biological and serological assays, complemented by electron microscopy confirmed the infection of these lily plants by an isolate of TBV (1).

Ref.: (1) Furlanetto, C. et al. Fitopatol. bras. 21: 431. 1996.

\section{*Lippia alba Mill.N.E.Br. ex Britt \& Wilson Verbenaceae Begomovirus \\ Begomovirus unidentified}

Mosaic symptoms in L. alba plants sampled in the state of Alagoas was attributed to a begomovirus, yet to be identified, associated with 
infestation by whiteflies (1).

Ref.: (1) Assunção, I.P. et al. Fitopatol.bras. 29: S161. 2004.

\section{*Luehea grandiflora Mart. Malvaceae}

Begomovirus

Infectious chlorosis of malvaceae complex (ICMC)

Posssible infection of $L$. grandifolia plants, showing mosaic symptoms, by a begomovirus considered as ICMC, was registered in the state of São Paulo (1).

Ref.: (1) Silberschmidt,K. \& Tommasi, L.R. Ann.Acad.Bras.Cien. 27: 195. 1955.

\section{*Luffa aegyptiaca Mill. (Sponge gourd) Cucurbitaceae Orthotospovirus \\ Zucchini lethal chlorosis virus (ZLCV)}

During a survey made in the state of S.Paulo for natural hosts for ZLCV, this virus was detected in field sponge gourd plants (1).

Ref.: (1) Camelo-Garcia, V. et al. Trop.Plt.Pathol. 40: 345. 2015.

*Luffa cylindrica Roem. (Loopha) Cucurbitaceae Potyvirus

Zucchini yellow mosaic virus (ZYMV)

Loopha plants exhibiting leaf necrosis, mosaic, ringspots and distortion and drying of fruits, were sampled in a commercial field in Jales, SP. Subsequent analysis indicated that this condition was caused by infection by an isolate of do ZYMV, identified by biological and serological assays and cytopathological analysis (1). ZYMV-infected loopha plants were also found in the state of Pará (2).

Ref.: (1) Colariccio, A. et al. Summa Phytopathol. 23: 58. 1997; (2) Hayashi, E.A. et al. Trop.Plt.Pathol. 38 (supl): .455-2. 2013.

\section{*Luffa operculata Cogn. Cucurbitaceae}

Potyvirus

Papaya ringspot virus (PRSV-W)

Natural infection of $L$. operculata by PRSV-W was reported in the state of Ceará, identification of the virus being made by biological and serological methods (1).

Ref.: (1) Lima, J.A.A. \& Florindo, M.I. Fitopatol.bras. 22: 213.1997.

*Lupinus alba L. (White lupine); L. luteus L.(Yellow lupine) Fabaceae

Potyvirus

\section{Bean yellow mosaic virus (BYMV)}

White and yellow lupines showing mosaic symptoms were observed in Cascavel, PR, and the causal agent identified as BYMV (1-3).

Ref.: (1) Almeida, A.M.R. Fitopatol.bras. 16: 288. 1991; (2) Ramagem, R.D. et al. Fitopatol. bras. 17: 178. 1992; (3) 179. 1992.

\section{*Lysimachia congestiflora Hemsl. (Golden globes) Primulaceae Cilevirus \\ Cilevirus unidentified}

L. congestiflora exhibiting chlorotic spots on leaves were found in a residential garden in Águas de S.Pedro, SP. Electron microscopy indicated the presence of a cilevirus, according to the observed cytopathic effects (1).

Ref.: (1) Nogueira, N.L. \& Rossi, M.L. Fitopatol.bras. 30 (supl.): S189. 2005.

\section{M}

*Macroptilum atropurpureum (DC) Urban (Siratro, Purple bush
bean) Fabaceae
Potyvirus

\section{Potyvirus unidentified}

Mosaic symptoms in siratro were found to be caused by a mechanical and aphid transmitted potyvirus, yet to be identified. These plants occurred in the states of Ceará (1) and São Paulo (2).

Ref.: (1) Marques, M.A.I. \& Albersio, J.A.A. Res. VI Enc.Nac.Virol. 170. 1992; (2) Regatieri, L.J. et al. Fitopatol.bras. 28: S289. 2003.

Begomovirus

\section{Euphorbia yellow mosaic virus (EuYMV)}

EuYMV was found infecting siratro in Caruaru, PE, being identified by molecular assays (1).

Ref.: (1) Silva, J.C.V. et al. Plant Pathol. 61: 457. 2012.

Tomato crinkle leaf yellows virus (TCrLYV)

Siratro infected by TCrLYV, as determined by molecular assays was found in Maceió, AL and Quipapa, PE (1).

Ref.: (1) Silva, J.C.V. et al. Plant Pathol. 61: 457. 2012.

\section{*Macroptilium erythroloma (Benth) Urban Fabaceae Begomovirus \\ Bean golden mosaic virus (BGMV)}

Natural infection of $M$. erythroloma by BGMV, resulting in a severe yellow mosaic was found in Nova Odessa, SP (1).

Ref.: (1) Chagas, C.M. et al. Arq.Inst.Biol. 48. 113. 1981.

\section{*Macroptilium lathyroides (L) Urban (=Phaseolus lathyroides) (Phasey bean) Fabaceae}

Comovirus

Cowpea severe mosaic virus (CPSMV);

A report was made in the state of Ceará, on the natural infection of phasey bean by CPSMV, resulting in mosaic symptoms $(1,2)$.

Ref.: (1) Lima, J.A.A. \& Chagas, J.M.F. Fitopatologia (Lima) 9: 58. 1974; (2) Lima, J.A.A. \& Santos, D.G. Fitopatol.bras. 10: 313. 1985. Begomovirus

Bean golden mosaic virus (BGMV)

M. lathyroides with mosaic symptoms, found in the state of Ceará, was associated with infection by a begomovirus, considered similar to Cowpea golden mosaic virus (1). In similar cases, noticed in União dos Palmares, AL (2), and in the states of Pernambuco and Sergipe (3) the causal virus was identified as BGMV.

Ref.: (1) Lima, J.A.A. et al. Virus Rev. \& Res. 3 (supl.1):143.1998; (2) Nascimento, L.D. et al. Fitopatol. bras. 31 (supl): S204. 2006; (3) Silva, J.C.V. et al. Plant Pathol. 61: 457. 2012.

Macroptilium yellow net virus (MaYNV)

MaYNV was found infecting phasey beans in the Brazilian Northeast (1).

Ref.: (1) Silva, S.J.C.. et al. Plant Pathol. 61: 457. 2012.

Macroptilium yellow spot virus (MaYSV)

Cases of infection of phasey bean by MaYSV were reported in the states of Paraíba and Alagoas (1) as well as in Pernambuco and Sergipe (2). These last two isolates have been characterized by biological methods and molecular tools (3).

Ref.: (1) Silva, S.J.C. et al. Plant Pathol. 61: 457. 2012; (2) Almeida, K.C. et al. Virus Rev.\& Res. 17 (supl.): 36. 2012; (3) Almeida, K.C. et al. Abst.7th Intl.Geminivirus Symp. P.60. 2013.

\section{Begomovirus unidentified}

A golden mosaic in phasey beans was observed in Juazeiro, BA (1), and in the state of Ceará (2), caused by a still unidentified begomovirus.

Ref: (1) Assunção, L.P. et al. Planta Daninha 24: 239. 2006; (2) Nascimento, A.K.Q. et al. Trop Plt Pathol 33(supl): 299. 2008.

*Macroptilium longepedunculatum Mart. Et. Benth. (=Phaseolus longipedunculatus) Fabaceae

Begomovirus 


\section{Bean golden mosaic virus (BGMV)}

Yellow mosaic bearing $M$. longepedunculatum plants were found in the Santos Dumont airpot, downtown of Rio de Janeiro, RJ. The virus was whitefly transmited showing some differences in host range with AbMBV in comparative studies without occurring cross protection (1), and considered as a possible isolate of BGMV (2).

Ref.: (1) Flores, E. \& Silberschmidt, K. An.Acad.Bras.Cien. 38: 327. 1966; (2) Costa, A.S. et al. Anais I Simp.Bras.Feijão (Campinas). P. 305. 1972.

\section{*Malus sp. (Apple) Rosaceae \\ Foveavirus \\ Apple stem pitting virus (ASPV)}

Incidence of ASPV among apple culture in Brazil is high. It causes stunting and loss of vigor in the indicator variety (1). ASPV was detected in clones from commercial apple grooves from Angatuba and Paranapanema, SP, by índex grafting (2), as well as in orchards from the states of Santa Catarina (3) and Rio Grande do Sul (4).

Ref.: (1) Betti, J.A. \& Ojima, M. Summa Phytopathol. 5: 29. 1979; (2) Betti, J.A. et al. Summa Phytopathol. 21: 49. 1995; (3) Nickel, O. et al. Fitopatol.bras. 23: 321. 1998; (4) Nickel, O. \& Fjardo, T.V.M. Trop. Plt.Pathol. 38(supl.): 28. 2013.

Capillovirus

Apple stem grooving virus (ASGV)

First descriptions of occurrence of ASGV in cultivated and asymptomatic apple plants were made in the state of São Paulo, by mechanical inoculation assays on test plants, including peach (1). Identification was confirmed by immuno electron microscopy (2). Minigrafiting and thermotherapy procedures managed to eliminate ASGV and ACLSV from infected plants (3). An internal necrosis in the rootstock Maruba Kaido, in the Experimental Station at Caçador, SC, was associated with infection by ASGV (4). Later ASGV was detected by serology in cvs. Rozala Gala and Fuji grafted on top of Maruba-Kaido in commercial nursery of the state of Rio Grande do Sul (5). This detection was complemented by the analysis of the coat protein gene (6). Two isolates of ASGV had their entire genome sequenced and showed high identity with the standard isolate (7).

Ref.: (1) Betti, J. \& Kitajima, E.W. Rev.Soc.Bras.Fitopat. 5: 125. 1971; (2) Gaspar, J.O. \& Betti, J.A. Summa Phytopathol. 11: 62. 1985; (3) Betti, J.A. \& Gaspar, J.O. Summa Phytopathol. 12: 19. 1986; (4) Betti, J.A. et al. Summa Phytopathol.. 14: 33. 1988; (5) Nickel, O. et al. Fitopatol. bras. 24: 444. 1999; (6) Nickel, O. et al. Fitopatol.bras. 25: 445. 2000.; (7) Souza, E.B. et al. Trop. plant Pathol. 42: 391. 2017. Trichovirus

\section{Apple chlorotic leaf spot virus (ACLSV)}

Latent infection of apple by ACLSV was first noticed in the state of São Paulo. The virus was detected by mechanical inoculation on assay hosts, including peach (1). Speckled mosaic in the cultivar Anna, grown in Paranapanema, SP, was attributed o ACLSV infection (2), which was confirmed by immuno electro microscopy (3). This virus was also detected in the states of Santa Catarina and Rio Grande do Sul (4).

Ref.: (1) Betti, J. \& Kitajima, E.W. Rev.Soc.Bras.Fitopat. 5: 125. 1972; (2) Betti, J.A. et al. Summa Phytopathol. 10: 126. 1984; (3) Gaspar, J.O. \& Betti, J.A. Summa Phytopathol. 11: 62. 1985; (4) Castro, L.A.S. et al. Fitopatol.bras. 23: 314. 1998.

Ilarvirus

\section{Apple mosaic virus (ApMV)}

Mosaic symptoms were observed in apple plants imported from Argentina in 1959 and considered to be caused by ApMV. Symptoms were either vein banding or vein clearing. Graft transmission experiments reproduced these symptoms in $40 \%$ of tested plants (1). ApMV was also found in Pelotas and Vacaria, RS (2).
Ref.: (1) Issa, E. O Biológico 25: 64. 1959; (2) de Castro, L.A.S. \& Daniels, J. Fitopatol. bras. 19: 313. 1994.

Unclassified ssDNA virrus

\section{Temperate fruit decay associated virus (TFDaV)}

Apple trees with stunting, chlorosis, weak budding and dried branches were observed in Viçosa, MG. Molecular assays indicated the presence of an unclassified ssDNA virus (TFDaV), associated with this condition (1). See details in Vitis vinifera.

Ref.: (1) Basso, M.F. et al. Virus Research 210: 27. 2015.

\section{*Malva sp. Malvaceae \\ Begomovirus \\ Okra mosaic Mexico virus (OkMMV) \\ Sida micrantha mosaic virus (SimMV) \\ Tomato leaf distortion virus (ToLDV)}

Malva sp. plants collected in different parts Brazil were found to be infected by several distinct begomoviruses. A sample from the Amazon basin had $87 \%$ of identity with OkMMV. Samples from the states of Rio de Janeiro and Goiás showed high identity with SmMV, okra isolate. Finally, plants coming from the state of Rio de Janeiro presented $90 \%$ of identity with ToLDV (1).

Ref.: (1) Fernandes, N.A.N. et al. Trop.Plt Pathol 34 (supl): S271. 2009.

\section{*Malva parviflora L. (Malva) Malvaceae \\ Potexivrus}

\section{Malva mosaic virus (MaMV)}

Systemic necrosis of leaves was observed in malva plants in the state of São Paulo. Electron microscopy associated a potexvirus, possibly Malva mosaic virus with this condition (1).

Ref.: (1) Costa, A.S. \& Kitajima, E.W. Bragantia 29: LI. 1970.

\section{Potyvirus}

\section{Malva vein clearing virus (MVCV)}

Malva plants showing vein clearing and mottling on leaves were found in the state of São Paulo, associated with a potyvirus, detected by electron microscopy (1). It is assumed that this potyvirus is Malva vein clearing virus (MVCV) described in the USA and Europe (2).

Ref.: (1) Kitajima, E.W. et al. Bragantia 21: CIII. 1962; (2) Costa, A.S. \& Duffus, J.E. Plant Dis.Reptr. 41: 1006. 1957.

\section{Begomovirus}

\section{Infectious chlorosis of malvaceae complex (ICMC)}

Angular spots and golden mosaic symptoms were observed in Malva sp. plants in S.Paulo and Mogi das Cruzes, SP and Porto Alegre, RS. The disease was associated with infection by ICMS (1).

Ref.: (1) Silberschmidt,K. \& Tommasi, L.R. Ann.Acad.Bras.Cien. 27: 195. 1955

\section{Begomovirus unidentified}

An unidentified begomovirus was detected by molecular means in malva plants with mottling, mosaic, golden mosaic and vein clearing collected in Brasilia, DF, without additional information (1). Ref.: (1) Fonseca, M.E.N. et al. Fitopatol.bras. 28: S248. 2003.

*Malvastrum coromandelianum Garcke (False mallow) Malvaceae Begomovirus

Infectious chlorosis of malvaceae complex (ICMC)

A mosaic observed in false mallow plants collected in Brotas, SP, was considered as caused by whitefly transmitted ICMC (1).

Ref.: (1) Silberschmidt, K. \& Tommasi, L.R. Ann.Acad.Bras.Cien. 27: 195. 1955.

\section{*Malvaviscus arboreus Cav. (Turk's hat) Malvaceae Dichorhabdovirus}

Clerodendrum chlorotic spot virus (CICSV) 
A dichorhavirus was first detected in Turk's hat plants forming a living fence in a residential garden in Piracicaba, SP, exhibiting chlorotic ringspots on their leaves. Electron microscopy detected cytopathic effects typical of dichorhavirus, and it was shown to be transmitted by Brevipalpus mites. The viral agent was identified as ClCSV $(1,2)$. It was also found in the state of Rio de Janeiro (2). Its genome was completely sequenced and confirmed to be a member of the genus Dichorhavirus, distinct from other known members (3). Ref.: (1) Kitajima, E.W. et al. Exp.Appl.Acarology 30: 135. 2003; 2) Kitajima, EW et al. Scientia Agricola 67: 348. 2010; (3) RamosGonzález, P.L. et al. Arch.Virol. 163: 2519. 2018.

Begomovirus

Malvaviscus yellow mosaic virus (MaYMV)

Yellow mosaic symptoms on $M$. arboreus leaves were known since the 1950's in the Experimental farm of the Instituto Agronômico de Campinas. Molecular analysis indicated that these plants were infected by a begomovirus named MaYMV, phylogenetically related to begomoviruses from North and Central America. A peculiarity of MaYMV is that it harbors a sequence of nonanucleotides, of nanovirus and alphasatelite types (1).

Ref.: (1) Lima, A.T.M. et al. Virus Ver.\&Res. 16 (supl.) 217. CDRom. 2011

\section{*Manihot esculenta Kranz (Cassava) Euphorbiaceae Nucleorhabdovirus \\ Nucleorhabdovirus unidentified}

Electron microscopy of an asymptomatic cassava plant, sampled in the state of São Paulo was found to be infected by an unidentified nucleorhabdovirus (1).

Ref.: (1) Kitajima, E.W. \& Costa, A.S. Fitopatol.bras. 4: 55. 1979

Potexvirus

\section{Cassava common mosaic virus- (CsCMV)}

Presence of CsCMV, infecting field plants of cassava cv. 'Aipim carvão', was first registered in an experimental field of Instituto Agronomico, Campinas, SP. This cassava disease is of rare occurrence and considered of marginal importance. Leaf symptoms are conspicuous mosaic followed by distortion. It is mechanically transmissible and is perpetuated by the use of cuttings from infected plants; it may be transmitted by the use of cutting tools (1). CsCMV was identified as a new species of potexvirus by its morphology and cytopathology (3-6). It was purified and a specific antiserum, obtained (2). This virus was detected in the germplasm bank maintained at the Embrapa/Mandioca e Fruteiras, Cruz das Almas, BA (7). CsCMV was detected in the state of Paraná (8), where it seems to be widespread (9).

Ref.: (1) Costa, A.S. J.Agronomia (Piracicaba) 3: 239. 1940; (2) Silva, D.M. et al. Bragantia 21: XCIX. 1962; (3) Kitajima, E.W. et al. Bragantia 24: 247. 1965; (4) Kitajima \& Costa, A.S. Bragantia 25: XXIII. 1966; (5) Costa, A.S. \& Kitajima, E.W. CMI/AAB Descr.Plant Viruses 90. 1972; (6) Costa, A.S. Fitopatologia (Lima) 8: 5. 1973; (7) Meissner Fo., P.E. \& Santana, E.N. Fitopatol.bras. 22: 342. 1997 (8) Carnelossi, P.R. et al. Virus Rev. \& Res 15 (supl): 132. 2010; (9) Silva, J.M. et al. Trop.Plant Pathol. 36: 271. 2011.

Phytoreovirus

Cassava frogskin disease associated virus (CaFDaV)

Frogskin of cassava is a disease characterized by hyperplastic symptoms like verrucosis. Roots become thinner with a thick cortical zone, brittle and wrinkled, with crevices. No obvious foliar symptoms are present. In Brazil, frogskin has been observed in the Amazon basin and it was also found in the germplasm collection of Embrapa Mandioca e Fruteiras, Cruz das Almas, BA. Besides symptoms, diagnosis can be made by the detection of dsRNA made by molecular means $(1,2)$. CaFDaV was previously described in Colombia (4). A phytoplasma of the group SrIII was detected associated with frogskin syndrome (7) as previously reported in Colombia (5). In the state of Rio de Janeiro frogskin was found only associated with CaFDaV, but not with phytoplasma (6).

Ref.: (1) Fukuda, C. Res.I Cong.Lat.Am.Raizes Trop./IX Cong.Bras. Mandioca res.105. 1992. (2) Poltronieri, L.S. et al. Fitopatol.bras. 23: 322. 1998; (3) Isoton, MF et al. IV Enc.Jovens Talentos Embrapa.p.23. 2009; (4) Calvert, L. et al. J.Phytopathol. 156: 647. 2008; (5) Alvarez, E. et al. Plant Dis. 93: 1139. 2009; (6) Brioso, P.S.T. et al. Summa Phytopathol. 39 (supl) CDRom. 2013; (7) Souza, A.N. et al., Plant Dis.98: 771, 2014.

Alphanecrovirus

Tobacco necrosis virus (TNV)

TNV was recovered from asymptomatic cassava plants, kept under greenhouse conditions, in Instituto Agronomico, Campinas, SP (1).

Ref.: (1) Costa, A.S. \& Carvalho, A.M.B. Bragantia 19: CXLVII. 1960.

\section{Cavemovirus}

\section{Cassava vein mosaic virus (CaVMV)}

Vein mosaic in cassava was first reported in cassava in the cv. 'Vassourinha', grown in an experimental field of Instituto Biológico, SP (1). Similar condition was observed in the cv. 'Brava Preta de Suruhy' in Instituto Agronomico, Campinas, SP (2). Symptoms of the disease are characterized by vein mosaic or banding in adult leaves, and a chlorosis which may spread to whole plant. The causal virus, CaVMV was identified as a possible caulimovirus, but it is now considered the type member of the genus Cavemovirus (3). It is not transmissible mechanically, and the vector is unknown. CaVMV was purified and a specific antiserum has been produced (4). The virus was detected serologically infecting cassava in the state of Piauí (5) and Ceará (6). In the state of Bahia, CaVMV infecting cassava was identified based on symptoms (8). No significative yield loss caused by $\mathrm{CaVMV}$ in cassava crops was observed, in a field assay carried out in the state of Ceará (7).

Ref.: (1) Silberschmidt, K. O Biológico 4: 177. 1938; (2) Costa, A.S. J.Agronomia (Piracicaba) 3: 239. 1940; (3) Kitajima, E.W. \& Costa, A.S. Bragantia 25: 211. 1966; (4) Lin, M.T. \& Kitajima, E.W. Fitopatol.bras. 5: 419. 1980; (5) Santos, A.A. \& Silva, H.P. Fitopatol. bras. 7: 545. 1982; (6) Santos, A.A. \& Kitajima, E.W. Fitopatol.bras. 15: 145.1990; (7) Santos, A.A. et al. Fitopatol.bras. 20: 506. 1995; (8) Meissner Fo., P.E. \& Santana, E.N. Fitopatol.bras. 22: 342. 1997.

\section{*Matayba ealeagnoides Radlk. Sapindaceae Tobamovirus \\ Pepper mild mottle virus (PMMoV)}

PMMoV was detected by serological assays in seedlings of $M$. ealeagnoides in a nursery of the Univ. Brasília, DF (1).

Ref.: (1) Batista, J.G. et al. Trop.Plt.Pathol. 40 (supl): 354.2. 2015.

\section{*Matthiola incana (L.) W. T. Aiton.(Hoary stock) Brassicaceae Caulimovirus \\ Cauliflower mosaic virus (CaMV)}

A possible isolate of $\mathrm{CaMV}$ was found associated with mosaic symptoms in the ornamental hoary stoch in the state of Rio Grande do Sul. Identification was based on symptoms and aphid (Myzus persicae and Brevicoryne brassicae) transmission (1).

Ref.: (1) Siqueira, O. \& Dionelo, S.B. Fitopatologia (Lima) 8: 19. 1973

\section{*Melochia sp. Malvaceae \\ Begomovirus}

Melochia mosaic virus (MelMV); Melochia yellow mosaic virus (MelYM) 
Melochia sp., a wild malvaceae, was found with yellow mosaic symptoms on leaves in Corumbá, MS. Molecular assays indicated the presence of two, possibly new species of begomovirus, tentatively named MelMV and MelYMV (1).

Ref.: (1) Fiallo-Olivé, E. et al. Arch. Virol. 160: 3161. 2015.

\section{*Mendicago sativa L. (Alfafa) Fabaceae \\ Alfamovirus \\ Alfalfa mosaic virus (AMV)}

AMV was first reported in Brazil infecting alfafa in Campinas and Araçoiaba da Serra, SP, causing typical symptoms of yellow mosaic with yellow rings or sinuous lines. The virus was identified by biological and morphological properties (1), and it was also found in alfalfa, in an experimental area in Piracicaba, SP (2).

Ref.: (1) Costa, A.S. et al. Summa Phytopathol. 6: 30. 1980; (2) Oliveira, P.R.D. et al. Fitopatol.bras. 11: 310. 1986.

\section{*Mimosa sensitiva L. Fabaceae}

Isometric virus, unclassified

Mimosa sensitiva mosaic virus (MiMV)

During plant viruses survey, $M$. sensitiva plants, part of spontaneous vegetation nearby Belém, PA, was found showing conspicuous mosaic symptoms. The causal virus was identified as an isometric virus, ca. $30 \mathrm{~nm}$ in diam., transmissible by mechanical means and by the chrysomelis beetle Diabrotica speciosa (Oliv.), but only to the same species (1). The virus was purified and a specific antiserum produced. Serological tests against 31 isometric viruses were all negative (2).

Ref.: (1) Kitajima, E.W. et al. Fitopatol.bras. 9: 394. 1984; (2) Marinho, V.L.A. et al. Fitopatol.bras 10: 308. 1985.

\section{*Mirabilis jalapa L. (Four o'clock) Nyctaginaceae Orthotospovirus Tomato chlorotic spot virus (TCSV)}

The ornamental four o'clock is commonly present in residential gardens and city parks in Brazil. Mosaic bearing plants were found in a park in São Paulo, SP. Transmission and RT-PCR assays indicated that the causal agent of the symptoms was an isolate of TCSV (1).

Ref.: (1) Duarte, L.M. et al. Australasian Plant Disease Notes 11: 6. 2016.

\section{*Momordica charantia L. (Bitter melon) Cucurbitaceae Cucumovirus \\ Cucumber mosaic virus (CMV)}

An isolate of CMV coud be recovered from bitter melon plants with mosaic symptoms in the state of São Paulo $(1,2)$.

Ref.: (1) Barradas, M.M. et al. Arq.Inst.Biol.. 46: 117. 1979; (2) Brioso, P.S.T. \& Lin, M.T. Fitopatol.bras. 9: 395. 1984.

Gemycircularvirus

Odonata associated gemycircularvirus 1 (OaGmV-1)

Molecular assays detected a gemycircularvirus in bitter melon, with high sequence identity with OaGmV-1 (1).

Ref.: (1) Rezende, R.R. et al. Arch.Virol. 163: 3163. 2018.

\section{*Monstera deliciosa Liebm. (Swiss cheese plant) Araceae Dichorhavirus \\ Dichorhavirus unidentified}

M. deleciosa plants with ringspot on their leaves were found nearby Manaus, AM. Tissues from these ringspots revealed cytopathic effects typical of dichorhavirus by electron microscopy (1).

Ref.: (1) Rodrigues, J.C.V. et al. Trop.Plt.Pathol. 33: 12. 2008.

\footnotetext{
*Musa spp. (Banana) Musaceae

Cucumovirus
}

\section{Cucumber mosaic virus (CMV)}

Infection of banana plants by CMV has been reported in Brazil since the 1930's (1). Symptoms are characterized by dark and clear streaks, continuous or not, originating from the main leaf vein. These streaks may evolve to necrosis, and wrinkling and reduction in leaf size may occur. CMV is aphid borne, being transmitted from other infected banana plants or from other host plants, mostly invasive. However, commonly, infection by CMV occurs by the use of shoots from infected mother plant. Original description was made in the state of São Paulo (1), but CMV is present in most of the banana producing areas of Brazil such as the states of Rio de Janeiro, Minas Gerais, Bahia, Pará, Paraná) (2-6, 7, 9, 10, 12,13). CMV group IA was identified in the state of São Paulo (7). Use of plants derived from massive multiplication of virus-free plantlets, obtained from tissue culture eliminates the initial infection. However, this practice requires rigorous control of the matrix plants, for cases of contamination with BSV has been reported, resulting in plants double infected by CMV and BSV in the field (11).

Ref.: (1) Deslandes, J. Rodriguesia 2 (no.esp.): 199. 1936; (2) Silberschmidt, K. \& Nobrega, N.V.R. O Biológico 7: 216. 1941; (3) Medeiros, A.G. Bol.Tecn.IPA 4: 1. 1963; (4) Robbs, C.F. Agronomia 22: 127. 1964; (5) Rbeiro, M.I.S.D. et al. Fitopatologia (Lima) 10: 62. 1975; (6) Lima, J.A.A. \& Gonçalves, M.F.B. Fitopatol. bras. 13: 101. 1988; (7)Eiras, M. et al. Fitopatol.bras. 25: 440. 2000; (8) MacielZambolim, E. et al. Fitopatol.bras. 19: 483. 1994; (9) Barbosa, C.J. et al. Res. XIV Cong.Bras.Frutic.: 73. 1996; (10) Trindade, D.R. et al. Fitopatol.bras. 23: 185. 1998; (11) Brioso, P.S.T. et al. Summa Phytopathol. 26: 254. 2000; (12) Nunes, A.M.L. et al. Fitopatol.bras. 26: 512.2001; (13) Carnelossi, P.R. et al. Trop.Plant Pathol. 36 (Supl.) CDRom. 2011.

\section{Badnavirus}

\section{Banana streak virus (BSV-OL)}

A disease of banana plants characterized by necrotic streaks on leaves is caused by BSV, whose genome is dsDNA and particles are bacilliform. It is spread in the field by mealybugs or through shoots of infected mother plant. It was first recorded in Brazil, in a case of coinfection with CMV, and detected by electron microscopy and PCR in the state of São Paulo (1). BSV has been detected in most of banana growing regions as states of Acre, Amazonas, Pará, Roraima, Bahia, Ceará., Goiás, Minas Gerais, Piauí, Rio de Janeiro, Santa Catarina, Pará, Amapá $(2,3,7,9)$. ICTV recognizes three species of BSV, Mysiore, OL and GF. The BSV present in Brazil is OL (4). In the state of Amazon, necrotic lesions were found in fruits, associated with infection by BSV (5). BSV was experimentally transmitted by the mealybug Planococcus citri from banana to banana (8).

Ref.: (1) Brioso, P.S.T. et al. Summa Phytopathol. 26: 254. 2000; (2) Figueiredo, D.V. et al. Fitopatol.bras. 32: 118. 2006. (3) Poltronieri, L.S. et al. Summa Pahytopathol. 35: 74. 2009.(4) Lombardi, R. et al. Pesq.Agrop.Bras. 45: 811. 2010; (5) Brioso, P.S.T. et al. Rev.Bras. Frutic. 33: 1353. 2011; (6) Brioso, P.S.T. Rev.Anual Patol. Planta 20: 64. 2012; (7) Bijora, T. et al. Trop.Plant Pathol. 38 (supl.) 2013; (8) Colariccio, A. et al Trop.Plt.Pathol. 33 (supl): S9.2008; (9) Colariccio, A. et al. Res.439, $50^{\circ}$ Cong.Bras.Fitopat. 2017.

\section{*Mussaenda erythrophylla Schumach. \& Thonn. (Ashanti blood) Rubiaceae \\ Dichorhavirus \\ Dichorhavirus unidentified}

Ashanti blood plants were found with chlorotic spots on leaves nearby Manaus, AM. Electron microscopy of tissues from lesions revealed cytopathic effects of dichorhavirus, still unidentified (1). Ref.: (1) Rodrigues, J.C.V. et al. Trop Plt Pathol 33: 12. 2008. 
$\mathbf{N}$

\section{*Nasturtium officinale R.Br. (Water crest) Brassicaceae \\ Cucumovirus}

\section{Cucumber mosaic virus (CMV)}

A report of possible infection of water crest by CMV was made on samples collected in the state of Minas Gerais (1).

Ref.: (1) Robbs, C.F. \& Viegas, E.C. Guia de Controle às pragas e doenças das Cult.Econo. do Estado, Sec.Agric.Abast., RJ. 84p. 1978 Potyvirus

\section{Turnip mosaic virus (TuMV)}

Water crest plants showing mosaic symptoms were found in Campos de Goytacazes, RJ. Biological assays and electron microscopy associated the disease with a potyvirus, tentatively identified as TuMV (1). A similar situation was found in high incidence in a commercial plantation at Marechal Floriano, ES. Elisa and RT-PCR experiments identified the causal virus as TuMV (2).

Ref.: (1) Boari, A.J. et al. Fitopatol.bras. 27: S200. 2002; (2) Costa, H. et al. Plant Dis.94: 1066. 2010.

Caulimovirus

\section{Cauliflower mosaic virus (CaMV)}

A case of infection of water crest by CaMV was reported in the state of Paraná (1).

Ref.: (1) Lima, M.L.R.Z.C. et al. Fitopatol.bras. 9:403. 1984.

\section{*Neonotonia wightii (Perennial soybean) Fabaceae \\ Begomovirus \\ Bean golden mosaic virus (BGMV)}

Perennial soybean plants showing characteristic symptoms of infection by begomovirus were found in Santo Antonio de Goiás, GO. Molecular assays indicated that these plants were infected by an isolate of BGMV (1).

Ref.: (1) Bertholdo, N.M. et al. Res.29 Cong.Bras.Virol. 2018.

\section{*Nematanthus sp. (= Hypocyrta nervosa) Gesneriaceae Cucumovirus \\ Cucumber mosaic virus (CMV)}

CMV was detected on Nemantathus sp. plants with chlorotic spots and rings on their leaves in Ibiúna, SP. Identification of CMV was based on biological and serological assays (1).

Ref.: (1) Duarte, L.M.L. et al. Fitopatol.bras. 21: 424. 1996.

\section{*Nicandra physaloides (L) Gaertn. (Shoo-fly plant) Solanceae Potyvirus \\ Potato virus Y (PVY)}

Natural infection of $N$. physaloides by PVY was noticed in the state of Minas Gerais (1)

Ref.: (1) Oliveira, C.D. et al. Fitopatol.bras. 21: 427. 1996.

\section{Papaya ringspot virus $W$ (PRSV)}

Watermelon mosaic virus (WMV)

\section{Zucchini yellow mosaic virus (ZYMV)}

A survey was carried out in weeds surrounding cucurbit fields in the state of Tocantins. PRSV-W and ZYMV were found in N. physaloides in Lagoa da Confusão, while in Formoso de Araguai, WMV was also found, besides these two viruses (1).

Ref.: (1) Aguiar, R.W.S. et al. Planta Daninha 36: :e018171593. 2018. Begomovirus

Tomato severe rugose virus (ToRSV); Tomato yellow vein streak virus (ToYVSV)

Molecular tools detected a begomovirus infecting shoo-fly plants in Brasília, DF, showing leaf deformation, without further information (1). There are also reports of begomovirus infecting $N$. physaloides in the states of São Paulo (2) and Minas Gerais (3). On the other hand, begomovirus found infecting shoo-fly plants in Sumaré, SP, was identified as ToRSV. Another isolate found in the states of Goiás and Distrito Federal was identified as ToYVSV (5).

Ref.: (1) Inoue-Nagata, A.K. et al. Virus Rev.\& Res. 8: 186. 2003; (2) Andrade,G.P. et al. Fitopatol.bras. 32 (supl): 322. 2007; (3). Fernandes, J.J. et al. Plant Pathol. 55: 513. 2006; (4) Barbosa, J.C. et al. Plant Pathology 75: 440.2009; (5) Fonseca, M.E.N. et al. Trop.Plt. Pathol. 34 (supl): S267. 2009.

\section{*Nicotiana tabacum L. (Tobacco) Solanaceae Orthotospovirus}

Groundnut ringspot virus (GRSV)

Tomato chlorotic spot virus (TCSV)

Tomato spotted wilt virus (TSWV)

"Vira-cabeça" (bent head) was a name given by growers to a condition they observed in tobacco fields, in which many plants had their tops bent as a consequence of one side being more necrotic than the other. First records were made in the state of São Paulo (1$3,7)$. This name also has been extended to other crops as tomato. However, the complete symptomatology is more varied. In the beginning, affected plants show vein clearing and wrinkling, followed by necrosis on leaves, which extends to the stem. Plants had their growth delayed and in many cases die. Sometimes the diseased plant may recover. It was shown that the disease is transmitted by thrips, mechanical means and grafting (6). The causal virus was identified Tomato spotted wilt virus, described in Australia (4), which has a large range of hosts, either natural or experimental. At this time, TSWV was the only species recognized in the genus Orthotospoviruses (5). After the discovery that Orthotospoviruses comprises many other species, TCSV was found infecting tobacco plants in the state of São Paulo, and GRSV (10) as well as TSWV (9), in the state of Alagoas.

Ref.: (1) Silberschmidt, K. O Biologico 3: 183. 1937; (2) Forster, R. \& Costa, A.S. Rev.Agric. (Piracicaba) 13: 69. 1938; (3) Costa, A.S. \& Forster, R. Bol. Tec. Inst. Agron. Campinas. 1939; (4) Bragantia 1: 491. 1941; (5) 2: 83. 1942; (6) Forster, R. Bragantia 2: 499. 1942; (7) Costa, A.S. Bol. Min. Agric. 82p. 1948; (8) Colariccio, A. et al. Fitopatol.bras. 20: 347. 1995; (9) Silva, J.N. et al. Fitopatol.bras. 24: 360.1999; (10) Lima, G.S.A. et al. Summa Phytopathol. 29: 196. 2003. Tymovirus

\section{Tomato blistering mosaic virus (ToBMV)}

A tymovirus was found infecting field tobacco plants in the state of Santa Catarina, and considered as an isolate of Eggplant mosaic virus (EMV) by biological, morphological and serological assays (1). However, a reassessment of its identity by molecular tools revealed that this virus was an isolate of ToBMV (2).

Ref.: (1) Ribeiro, S.G. et al. Plant Dis. 80: 446. 1996; (2) Melo, F.L. et al. Virus Gene Annouc.2: e00701-14-e00701-14. 2014.

\section{Cucumovirus}

\section{Cucumber mosaic virus (CMV)}

CMV causes intense mosaic in tobacco leaves, but it is of sporadic occurrence. This virus was reported for the first time in Brzsil in the state of São Paulo (1), and has been found in most of tobacco producing regions in the states of Sergipe (2), Santa Catarina (3), Alagoas (4), Minas Gerais (5). Some CMV isolates found in the state of Minas Gerais were accompanied by satellite RNA (6).

Ref.: (1) Costa, A.S. Bragantia 4: 489. 1944; (2) Oliveira, G.H. \& Kitajima, E.W.- pers.comm. (3) Brioso, P.S.T. Tese Dr.,UnB. 1986; (4) Silva, J.N. et al. Fitopatol.bras. 24: 360. 1999; (5) Boari, A.J. et al. Fitopatol.bras. 25:49. 2000; (6) 25: 143. 2000.

Ilarvirus

\section{Tobacco streak virus (TSV)}

A tobacco disease characterized by a white necrosis (white necrotic lines, running parallel to the veins) was observed in 1937/1938 
in the state of São Paulo. Young leaves emerging after these initial symptoms are asymptomatic, but are followed by a phase coined "couve" (kale), because they are thicker, with dented borders and narrowed. Flowers may exhibit separated and thinner petals, with acute ends. Incidence of the disease in tobacco fields is very low. It is mechanically transmissible, with a wide host range. The causal agent was identified as an isolate of TSV, described in the USA (1-3). There is only one experiment showing that thrips may transmit TSV from infected Ambrosia polystachya to tobacco and soybean (5). TSV has been purified and a specific antiserum was obtained (4).

Ref.: (1) Costa, A.S. et al. J.Agronomia (Piracicaba) 3: 1. 1940; (2) Phytopathology 35: 1029. 1945; (3) Costa, A.S. \& Carvalho, A.M.B. Phytopathol.Zeit. 42: 113. 1961; (4) Silva, D.M. et al. Bragantia 20:777. 1961; (5) Lima No., V.C. et al. Rev. Setor Cien.Agr.UFPr 4:1. 1982.

Potyvirus

Potato virus $Y$ (PVY)

First mention of PVY infecting tobacco was made in cv.'Virginia', grown in Tremembé, SP, in an experimental field of the Instituto Biológico in 1939. Infected plants exhibited chlorotic spots usually accompanying veins, without deforming leaves. It was transmitted mechanically (1) and identified as an isolate of PVY (2).

Ref. (1) Kramer, M. \& Silberschmidt, K. Arq.Inst.Biol. 11: 165. 1940;

(2) Costa, A.S. \& Forster, R. Bragantia 2: 55. 1942.

Alphanecrovirus

\section{Tobacco necrosis virus (TNV)}

TNV was recovered from tobacco and Nicotiana clevelandii grown under greenhouse conditions in the Instituto Agronomico, Campinas, SP (1).

Ref.: (1) Costa, A.S. \& Carvalho , A.M.B. Bragantia 19: CXLVII. 1960.

\section{Tobamovirus}

\section{Tobacco mosaic virus (TMV)}

TMV was first described in Brazil infecting tobacco in the state of São Paulo in 1936. Infected plants showed systemic mosaic and reduction in size (1). The virus was recovered from several brands of commercial cigarrets and roll smoke (2). TMV was found infecting tobacco in the state of Alagoas (3).

Ref.: (1) Silberschmidt, K. O Biologico 2: 381. 1936; (2) Costa, A.S. \& Forster, R. O Agronômico 1: 252. 1941; (3) Silva, J.N. et al. Fitopatol.bras. 24: 360.1999.

Begomovirus

Sida micrantha mosaic virus (SimMV)

Tobacco plants showing severe yellow mosaic were found in Cachoeirinha, RS. The disease was attributed do SimMV infection based on molecular analysis, although Koch's postulate has not been completed (1). This virus was also found infecting tobacco in the state of Paraná (2).

Ref.: (1) Barros, D.R. et al. Virus Rev.\& Res. 13 (supl.2): 272. 2008; (2) Sawazaki, H.E. et al. Summa Phytopathol. 39 supl.CDRom. 2013. Tomato severe rugose virus (ToSRV)

A case of natural infection of tobacco by ToSRV was registered in Cascavel, PR (1).

Ref.: (1) Souza Dias, J.A.C. et al. Summa Phytopathol. 36: (supl) \#211. CDRom 2010.

Curtovirus, putative

Brazilian tomato curly top virus (BrCTV)

Two types of wrinkling, rough and curled, have been observed in tobacco plants in the state of São Paulo. Curling type was considered of genetic origin, while the rough, of possible viral cause (1). Subsequent works showed that the rough type was caused by the same virus that cause curly top in tomato, transmitted by hoppers Agallia, possibly related to the Beet curly top virus, described in the USA (2).
Ref.: (1) Costa, A.S. \& Forster, R. J.Agronomia (Piracicaba) 2: 295. 1939; (2) Bennett, C.W. \& Costa, A.S. J.Agric.Res. 78: 675. 1949.

\section{$\mathbf{O}$}

\section{*Ocimum basilicum L. (Basel) Lamiaceae Tobamovirus \\ Tobamovirus unidentified}

Rod-like particles were found by electron microscopy in extracts of basel showing chlorotic spots, in São Paulo, SP. The putative viral agent was not identified (1).

Ref.: (1) Chagas, C.M. \& Colariccio, A. Fitopatol.bras. 18: 278. 1993.

\section{*Ocimum campechianum Willd. (Alfavaca) Lamiaceae \\ Cucumovirus}

\section{Cucumber mosaic virus (CMV)}

Alfavaca with mosaic symptoms were found nearby Belém, PA. Causal agent was identified as an isolate of CMV after biological and molecular tests (1).

Ref.: (1) Carvalho, T.P. et al. Trop.Plt.Pathol. 38 (supl.):CDRom 2862. 2013.

\section{*Orchid (several genera) Orchidaceae \\ Cytorhabdovirus \\ Cytorhabdovirus unidentified}

Unidentified cytorhabdovirus was detected by electron microscopy in Laelia tenebrosa with necrotic ringspots (1).

Ref.: (1) Chagas, C.M. et al. Fitopatol.bras. 13: 132.1988

\section{Dichorhabdovirus}

\section{Orchid fleck virus (OFV)}

Though the term "orchid fleck" refers to spots on leaves, symptoms caused by OFV are varied: chlorotic or necrotic spots, streaks and ringspots. They depend on species and/or genus of the infected orchids. First reported in Japan in 1969, the virus was found to be dispersed in the world, almost certainly due to the intense international exchange, either legal or illegal. Virus particles are short, rod-like (ca. $40 \mathrm{~nm} \times 100-110 \mathrm{~nm}$ ) which in infected cells may occur in the nucleus or cytoplasm; a characteristic electron-lucent inclusion (viroplasm) is noticeable in the nucleus. OFV has been reported naturally infecting many orchid genera (Aspasia, Bifrenaria, Brassia, Cattleya, Coelogyne, Cymbidium, Dendrobium, Encyclia, Hormidium, Maxillaria, Miltonia, Odontoglossum, Oncidium, Oncidium x Odontoglossum, Pahiopedilum, Phalaenopsis, Stanhopea e Trigonidium, Xylobium, etc.). In Brazil, first report of occurrence of OFV was made in several orchid types, maintained in the collection of the Genetic Department, ESALQ/USP, Piracicaba, SP, which were showing mostly chlorotic and/or necrotic spots and ringspots. Electron microscopy showed the typical cytopathic effects described originally for OFV (1). A survey made on several commercial orchid growers found several cases of OFV infection (2). Immunoelectron microscopic studies confirmed that rod-shaped particles are OFV and that viroplasm contains OFVcoded proteins (3). Transmission of OFV by B. californicus was also confirmed in Brazil (4). Further surveys found OFV-infected orchids in the states of Rio Grande do Sul, Paraná, Santa Catarina, Minas Gerais, Mato Grosso do Sul, Rio Grande do $\operatorname{Sul}(5,6)$.

Ref.: (1) Kitajima, E.W. et al. Phytopathol.Zeit. 81: 280. 1974; (2) Freitas-Astua, J. et al. Fitopatol. Bras. 24: 125. 1999. (3) Kitajima, E.W. et al. J.gen.Plant Pathol. 67 (3):231. 2001; (4) Ferreira, P.T.O. et al. Fitopatol.bras. 28: S250. 2003; (5) Kubo, K.S. Tese Dr. USP. 2009; (6) Kubo, K.S. et al. J gen. Plt. Pathol. 75: 250. 2009.

Orthotospovirus

\section{Orthotospovirus unidentified}

An unidentified Orthotospovirus was detected by electron 
microscopy in Oncidium sp. with mosaic and chlorotic spots on leaves and necrosis in the floral stem, in the state of São Paulo (1). Presence of Orthotospovirus was confirmed by by RT-PCR (2).

Ref.: (1) Alexandre, M.A.V. et al. Bol. Téc. Inst. Biol., n²5: 69-82, 2012; (2) Rivas et al. Res. do $13^{\circ}$ Congr. Bras. de Floricult. e Plantas Ornam., p. 138. 2001.

\section{Potexvirus}

\section{Cymbidium mosaic virus (CymMV)}

Cases of infection of Cymbidium sp. and Laelia purpurata by CymMV, resulting respectively in mosaic and necrotic spot symptoms were registered in the state of São Paulo. Identification of the causal virus was base on serology and electron microscopy (1). In the state of Paraná, CymMV was found infecting Cattleya and Cymbidium orchids (2). In a survey made on the orchid collection of the Dept.Genética, ESALQ/USP, Piracicaba, SP, CymMV was found infecting the following orchid genera Anselliia, Cattleya, Coelogyne, Cymbidium, Dendrobium, Dendrochilum, Laelia, Oncidium, Phalaenopsis, Psychopsis and hybrids such as Brassolaeliocattleya, Laeliocattleya e Sophrolaeliocattleya (3). CyMV was detected in the state of Rio de Janeiro infecting Arundina (4). In a survey made in the state of Paraíba, CyMV was found infecting Cattleya (5).

Ref.: (1) Chagas, C.M. et al. O Biológico 43: 72. 1977; (2) Souto, E.R. et al. Fitopatol. Bras. 16: XXV.1 991. (3); Freitas-Astua, J. et al. Fitopatol. Bras. 24: 125. 1999; (4) Klein, E.H.S. et al. Trop.Plt Pathol 33(supl): S285. 2008; (5) Vilar, L.P. et al. Res.14, 40 CPFitop. 2017.

\section{Cucumovirus}

\section{Cucumber mosaic virus (CMV)}

CMV was identified infecting Dendrobium nobile causing chlorosis, mottling, whitish spots and stunting, in Santos, SP. Biological assays based this identification, although this orchid species could not be infected experimentally by CMV (1).

Ref.: (1) Nóbrega, N.R. O Biológico 13: 62. 1947.

Cilevirus

\section{Cilevirus unidentified}

During orchid viruses survey in the collection maintained at the Dept. Genética, ESALQ/USP, Piracicaba, SP, Phaius and Xylobium orchids were showing symptoms essentially similar to those caused by OFV. However, electron microscopy demonstrated cytopathic effects characteristic of cilevirus which could not be identified (1). Similar finding was made in orchid samples from commercial growers of the state of São Paulo (2) and in a sample of Arundina, collected in Manaus, AM (3).

Ref.: (1) ; Freitas-Astua, J. et al. Fitopatol. Bras. 24: 125. 99; (2) Kubo, K.S. et al. Fitopatol. bras. 31 (upl): S377. 2006. (3) Rodrigues, J.C.V. et al. Trop Plt Pathol 33: 12. 2008.

Tobamovirus

\section{Odontoglossum ringspot virus (ORSV)}

ORSV was detected by serology and electron microscopy in plants of Laelia tenebrosa exhibiting necrotic ringspots in the state of São Paulo (1). Similar findings were made in Cattleya in the state of Minas Gerais (2) and DF (4). In a large survey for orchid viruses made in commercial nurseries and in the collection of Dept. Genética, ESALQ/ USP, Piracicaba, SP, ORSV was found in the following orchid genera: Cattleya, Cymbidium, Encyuclia, Epidendrum, Laelia, Laeliacattleya, Phalaenopsis, Oncidium e Xylobium (3). ORSV was found infecting Cattleya and Spathoglottes orchids (5).

Ref.: (1) Chagas, C.M. et al. Res.IV Enc.Nac.Virol.p. 217. 1988; (2) Gonzales-Segana,LR. et al. Fitopatol.bras. 15: 152.1990; (3) FreitasAstua, J. et al. Fitopatol. bras. 24: 125. 1999; (4) Alves, D.M.T. et al. Virus Rev.\& Res. 9: 253. 2004.; (5) Vilar, L.P. et al. Res.14, 40 CPFitop. 2017.

\section{*Oryza sativa L. (Rice) Poaceae}

Benyvirus

Rice stripe necrosis virus (RSNV)

Rice plants with stripe necrosis symptoms were observed in the central region of the state of Rio Grande do Sul. Samples were sent to CIAT in Colombia, in which RSNV was detected by molecular analysis (1).

Ref (1) Maciel, J.L.N. et al. Fitopatol.bras. 31: 209. 2006.

\section{*Oxalis latifolia Kunth (Garden pink-sorrel) Oxalidaceae Begomovirus \\ Sida micrantha mosaic virus (SiMMV)}

Oxalis sp. plants, showing a conspicuous yellow mosaic and leaf distortion and colonized by whiteflies, were found to be infected by an isolate of SiMMV, based on PCR assays $(1,2)$.

Ref.: (1) Fonseca, M.E.N. et al. Summa Phytopathol. 30: 106. 2004; (2) Lamas, N.S. et al. Virus Rev. \& Res. 21: 129. 2016.

\section{*Oxalis oxyptera Progel Oxalidaceae Begomovirus}

Infectious chlorosis of malvaceae complex (ICMC)

Yellow net symptoms were observed in $O$. oxyptera growing in the state of São Paulo. Causal virus was identified as a whitefly Bemisia tabaci-transmitted begomovirus of ICMC (1). Similar case was noticed in the state of Paraná (2).

Ref.: (1) Costa, A.S. Summa Phytopathol. 4: 3. 1978; (2) Lima No., V.C. et al. Rev.Setor Cien.Agr.UFPr 4: 1. 1982.

\section{*Oxalis spp., Oxalidaceae \\ Begomovirus}

\section{Sida micrantha mosaic virus (SiMMV)}

Oxalis spp. plants with yellow mosaic and golden spots symptoms were found in the Federal District, Formosa, GO and Londrina, PR. Molecular assays indicated a case of infection of these plants by an isolate of SiMMV (1).

Ref.: (1) Fontenele, R.S. et al. Plant Dis. 102: 1862. 2018.

\section{$\mathbf{P}$}

\section{*Panicum maximum Jacq. Poaceae Potyvirus \\ Johnson grass mosaic virus (JGMV)}

JGMV was detected infecting $P$. maxium samples showing mosaic symptoms, collected in São Luis de Paraitinga, SP. Its identification was based in electron microscopy and RT-PCR. Complete genome sequence of this isolated was obtained, revealing $82 \%$ identity with an Australian isolate deposited in the GenBank. Mechanical transmission assays showed that this isolate of JGMV can infect many poaceae hosts (2). An unidentified potyvirus in $P$. maximum reported in the state of Mato Grosso may represent a case of infection by JGMV (1) Ref.: (1) Silva, M.S. et al. Fitopatol.bras. 31(supl):S192. 2006; (2) Camelo-Garcia, V.M. et al. Arch.Virol. 161: 1335. 2016.

\section{*Panicum sp. Poaceae \\ Waikavirus \\ Maize chlorotic dwarf virus (MCDV)}

Mosaic symptoms were observed in Panicum sp. being assayed at Embrapa Gado de Corte, Campo Grande, MS. Molecular assays detected MCDV associated to the symptoms (1).

Ref.: (1) Silva, K.N. et al. Virus Rev \& Res.20 (supl.): 211.2015.

\section{* Parthenium hysterophorus (Santa Maria) Asteraceae Begomovirus}

Euphorbia yellow mosaic Virus (EuYMV) 
EuYMV was detected by molecular assays infecting $P$. hysterophorus plants, with typical symptoms of infection by begomovirus in Santo Antonio de Goiás, GO (1).

Ref.: (1) Bertholdo, N.M. et al. Res.29 Cong.Bras.Virol. 2018.

\section{*Paspalum conjugatum Bergius (Sour paspalum) Poaceae Potyviruis \\ Potyvirus unidentified}

Chlorotic stripes sometimes followed by reddening of the leaves were observed in $100 \%$ of plants at the Experimental Station of Instituto Agronomico, in Capão Bonito, SP. Electron microscopy detected an unidentified potyvirus, which could not be transmitted mechanically, by seed or by aphids (1).

Ref.: (1) Vega, J. \& Costa, A.S. Fitopatol.bras. 13: 101.1988.

\section{* Passiflora alata Curtis. Passifloraceae Vitivirus \\ Grapevine virus $A$ (GVA)}

Electron microscopy detected closterovirus-like particles in asymptomatic plants of $P$. alata in the states of São Paulo and Minas Gerais (1). These particles reacted with anti-GVA serum in immunoelectron microscopic assays. RT-PCR confirmed the presence of GVA in these samples (2).

Ref.: (1) Chagas C.M. et al., Fitopatol. Bras.17:218, 1992; (2) Galleti, S.R. Fitopatol.bras.31:S373.2006.

\section{*Passiflora edulis Sims. (Purple granadilla) \\ Isometric virus, unclassified \\ Purple granadilla mosaic virus (PGrMV)}

Light mosaic, vein clearing of line pattern type, smaller plant size and occasional hardening of fruits was observed in purple granadilla in a backyard plantation at Cotia, SP (1). It is mechanically transmissible, and the unidentified causal virus is isometric $(30 \mathrm{~nm}$ diam) occurring in high concentration in infected tissues, and induces a peculiar cytopathic effect- fibrous inclusions in mitochondria (2). The chrysomelid beetle Diabrotica speciosa transmitted this virus. Coat protein of virions are made up by a single protein of $35,5 \mathrm{kDa}$, and the genome is a ssRNA of $1,8 \mathrm{mDa}$. It was purified and a specific antiserum, produced. No serological relationship could be established with 33 isometric viruses assayed, and its identity still remains obscure (3).

Ref.: (1) Chagas, C.M. et al. Fitopat.Bras. 9: 241. 1984; (2) Vega, J. \& Chagas, C.M. Fitopatol.bras. 8: 621. 1983; (3) Oliveira, C.R.B. et al. Fitopatol.bras. 19:455. 1994.

*P. edulis Sims. f. flavicarpa DEG. (Yellow passion fruit); $P$. coccínea Aubl. $x$ P. setacea D.C. Passifloraceae

Nucleorhabdovirus

Nucleorhabdovirus unidentified

A condition known locally as "enfezamento", characterized by passion flower plants with short internodes, leaves with reduced size, coriaceus, with vein clearing, few flowers and fruits has been reported in production areas of the state of Sergipe (1). It was also observed in the states of Rio de Janeiro (2), Rio Grande do Sul (3), Paraná (4), São Paulo (6), Bahia (7) and Pará (8). This disease is graft transmissible and is associated with the presence of an unidentified nucleorhabdovirus (5).

Ref.: (1) Batista, F.A.S. et al. Anais VI Cong.Bras.Frutic. 1408.1981; (2) Kitajima, E.W. et al. Fitopatol.bras. 9: 607. 1984; (3) Prata, C.H.S. Diss.Mest.UFRGS75p. 1984; (4) Souza, V.B.V. et al. Rev.Setor Cien.Agr.UFPR 6: 101. 1984; (5) Kitajima, E.W. \& Crestani, O.A. Fitopatol.bras. 10: 681. 1985; (6) Chagas, C.M. et al. Fitopatol.bras. 12: 275. 1987; (7) Barbosa, C.J. et al. Fitopatol. bras. 24: 350. 1999;
(8) Nogueira, M.S.R. et al. Virus Rev. \& Res 11(supl): 187. 2006 Tymovirus

\section{Passionfruit yellow mosaic virus (PFYMV)}

During a plant virus survey in the state Rio de Janeiro, passion flower plants showing bright yellow mosaic on leaves were found in Cachoeira do Macacu, RJ. Incidence was very low, and besides leaf symptoms, affected plants looked normal and yield apparently is not affected. The causal agent was identified as a new species of tymovirus, named PFYMV. It was easily transmitted mechanically and by the chrysomelid beetle Diabrotica speciosa. Host range of PFYMV was restricted to passifloraceae species. There is no additional report of its occurrence in Brazil, but it was detected in Colombia, where molecular tools confirmed that PFYMV is a distinct species in the genus tymovirus.

Ref.: (1) Crestani, O.A. et al. Phytopathology 76: 951.1986.

Cucumovirus

Cucumber mosaic virus (CMV)

Infection of passion flower by CMV was first reported in the state of São Paulo (1, 2), and later in Bahia (3), Paraná (4) and Sergipe (5). This virus is commonly present where passion flower is cultivated, but in very low incidence. Leaf symptoms are represented by bright yellow spots and rings; fruits become smaller and deformed. It is spread in the field by aphids, and experimentally Myzus persicae was able to transmit CMV to passion flower. CMV seems to have limited movement in infected plants, and commonly recovery of infection occurs. New shoots after the infected portion are symptomless (6).

Ref.: (1) Cereda, E. Summa Phytopathol. 9: 30. 1983, (2) Colariccio, A. et al. Summa Phytopathol. 10: 118. 1984; (3) Chagas, C.M. et al. Fitopatol.bras. 9: 402.1984; (4) Barbosa, C.J. et al. Fitopatol. bras. 24:193. 1999; (5) Gonçalves, L.O. et al. Fitopatol.bras. 31 (supl): S340. 2006. (6) Gioria, R. et al. Plant Pathol. 51: 127. 2002;

\section{Cilevirus}

Passionfrut green spot virus (PFGSV)

Vera Cruz, SP was a traditional coffed growing region, but in last decades yellow passion flower was considered another option, especially for small producers. In the 1990's a serious problem affected these plantations. It was characterized by green spots in ripe fruits and senescent leaves, as well as necrotic lesions in the stems, which when fused caused annealing and as a result, death of the plant. In some fields, losses were $100 \%$. Investigations revealed that this disease, coined "green spot", is caused by a Brevipalpus-mite transmitted cilevirus by biological assays and electron microscopy. The virus was named PFGSV, and chemical control of mite infestation was recommended as basic control measure, which worked fine (1). Later green spot of passion flower was also observed in the states of Bahia (2), Minas Gerais (3), Maranhão (4), Mato Grosso do Sul (7). It was also found infecting sweet passion fruit, P. alata in the state of São Paulo (5). Genome of PFGSV was partially sequenced, being distinct from Citrus leprosis virus $C$ (CiLV-C) (6).

Ref.: (1) Kitajima, E.W. et al., Fitopatol.bras. 22: 555. 1997; (2) Santos Fo., H.P. et al. Virus Rev.\&Res. 4: 150. 1999; (3) Takatsu, A. et al. Fitopatol.bras. 25: 332. 2000; (4) Moraes, F.H.R. et al. Fitopatol.bras. 31: 100. 2006; (5) Chagas, C.M. et al. Fitopatol.bras. 29 (supl.): S148. 2004 (6) Antonioli-Luizon, R. Tese MS ESALQ. 2010.; (7) ChabiJesus, C. et al. Res.\#189, $28^{\circ}$ Cong.Bras.Virol. 2017.

\section{Polerovirus}

\section{Cucurbit aphid-borne yellows virus (CABYV)}

Passion flower plants showing mosaic and leaf deformation were collected in Lençois and Jussiape, BA. Molecular assays carried out on extracted dsRNA followed by sequencing demonstrated that these plants were infected by CABYV (1).

Ref.: (1) Vidal, A.H. et al. Plant Dis. 102: 2665. 2018.

Potyvirus

https://doi.org/10.1590/1676-0611-BN-2019-0932 


\section{Cowpea aphid-borne mosaic virus P (CABMV-P)}

A condition essentially similar to "woodiness" previously described in Australia, being caused by a potyvirus, Passion fruit woodiness virus (PWV) was observed in Feira de Santana, BA. Symptoms were a severe mosaic and leaf deformation, short internodes, witches' broom, floral abortion and woody and deformed fruits (1). Indeed a potyvirus serologically related to PWV was detected by serology. Thus causal agent was thought to be an isolate of PWV. Similar diseases were later reported in a collection of Passiflora of UNESP, Jaboticabal, SP $(3,4)$ and also in commercial plantations in the states of Alagoas $(6)$, Distrito Federal (7), Minas Gerais (5), Ceará (8). Paraná (9), Pará (12), Maranhão (14), Sergipe (16), Santa Catarina (18), Mato Grosso do Sul (20), Amazonas (20), Piauí (24). The virus was experimentally transmitted by several aphid species (Myzus persicae, A. solanella, Toxoptera citricidus, Uroleucon ambrosiae, $U$. sonchii) (10). Molecular analysis of the coat protein gene of this potyvirus revealed a larger homology to CABMV than to PWV $(11,13)$, thus the causal agent of woodiness symptoms in Brazil was considered an isolate of CABMV (CABMV-P). Transgenic plants expressing coat protein and replicase were resistant to CABMV-P under experimental conditions $(12,19)$. A mild isolate of CABMV-P which cause mottling was able to infect cucurbits experimentally (15). P. suberosa revealed to be immune to infection by CABMV-P (17). In the state of São Paulo a natural infection of the hybrid $P$. coccinea $x$ P. setacea (Cerrado's star) was reported (20). Epidemiological studies showed predominance of aphids of the genus Aphis in passion flower fields in the Eastern state of São Paulo, being probably main vectors of CABMV-P (23).

Ref.: (1) Yamashiro, T. \& Chagas, C.M. Na. $5^{\circ}$ Cong.Bras.Frutic.: 915. 1979; (2) Chagas, C.M. et al. Fitopatol.bras. 6: 259. 1981; (3) Cereda, E. Summa Phytopathol. 9: 30. 1983; (4) Chagas, C.M. et al. Rev.Bras. Fruticult. 14: 187. 1992; (5) São José, A.R. et al. An. 13o Cong.Bras. Frutic.: 797. 1994; (6) Costa, A.F. et al. Fitopatol.bras. 19: 226. 1994; (7) Inoue,A.K. et al. Fitopatol.bras. 20: 479. 1995; (8) Bezerra, D.R. \& Lima, J.A.A. Fitopatol. bras. 20: 553. 1995; (9) Barbosa, C.J. et al. Fitopatol. bras. 20: 302. 1995; (10) Costa, A.F. et al. Fitopatol.bras. 20: 376. 1995; (11) Santana, E.N. et al. Virus Rev. \& Res. 4: 156. 1999; (12) Trindade, D.R. et al. Fitopatol.bras. 24: 196. 1999; (12) Torres, L.B. et al. Virus Rev.\& Res. 6: 161. 2001; (13) Nascimento, A.V.S. et al. Fitopatol.bras. 29: 378. 2004 (14) Belo, R.F. et al. Fitopatol. bras. 29: S87. 2004; (15) Gioria, R. et al. Summa Phytopathol. 30: 256. 2004. (16) Gonçalves, LO et al. Fitopatol.bras.31 (supl): S340. 2006. (17) Nakano, DH et al. Fitopatol.bras. 31(supl):S325. 2006. (18) Colariccio,A . et al. Trop.Plt.Pathol. 33 (supl): S300. 2008; (19) Trevisan, F. et al. Plant Dis. 90: 1016. 2006; (20) Stangarlin, AP et al. Summa Phytopathol. 37 (supl.) CDRom. 2011; (21) Mello, A.P.O.A. et al. Summa Phytopathol 38 (supl.) CDRom 2012; (22) Costa, C.R.X. et al. Trop.Plant Pathol. 37 (supl.) CDRom 2012; (23) Garcez, R.M. et al. Hemipteran-Plant Interactions Symposium. Anais... Res.\#39. p.11. 2011.; (24) Beserra Jr., J.E.A. et al. Summa Phytopathol. 39(supl) CDRom 2013.

Begomovirus

\section{Passion flower little leaf mosaic virus (PLLMV)}

$100 \%$ incidence of a condition characterized by yellow mosaic, wrinkling, reduction of size of leaves, and limited development of plants, associated with a severe infestation with whiteflies was observed in passion flower plantations in Livramento de Nossa Senhora, BA. Subsequent works involving biological, serological and molecular assays, and electron microscopy, demonstrated that these plants had a double infection with CABMV and a begomovirus (1). Begomovirus was isolated by whitefly transmission and caused mosaic and small leaves in infected passion flower plants. It was characterized by molecular means and considered as a new species and named PLLMV. Partial sequence of DNA-A showed similarities with other begomoviruses from the New World. A similar begomovirus was found infecting passion flower in S. Fidelis, RJ which had $89 \%$ identity with Sida mottle virus (SiMoV) $(2,3)$. Further works carried out in begomoviruses isolated from passion flower in Paragominas (PA) and São Fidelis (RJ) showed that DNA-A had 90\% similarity with SiMoV, while another isolate from Araguari (MG) had $96 \%$ de similarity SimMV. It was not possible to transmit these isolates with Bemisia tabaci biotype B, though they had acquired the virus (3).

Ref.: (1) Novaes, Q.S. et al. Plant Pathology 52: 648. 2003.(2) Moreira, A.G. et al. Fitopatol.bras. 31 (supl): 2006; (3) Alves, A.C.C.N. et al. Virus Rev.\&Res. 16 (supl.) CDRom. 2011.

\section{Passion fruit chlorotic mottle virus (PCMoV)}

During surveys carried out on passion flower fields in the state of Mato Grosso do Sul, plants showing chlorosis, leaf crinkling and deformation were observed. Molecular analysis on these samples detected a begomovirus distinct from other previously known and tentatively named PCMoV. An infectious clone of PCMoV was produced (1).

Ref.: (1) Fontenele, R.S. et al. Viruses 10: 169. 2018.

\section{Passionfruit severe leaf distortion virus (PSLDV)}

Another begomovirus was isolated from passion flower in the state of Bahia. Analysis of the DNA-A sequence indicated $77 \%$ similarity with that of Tomato chlorotic mottle virus, while with DNA- B the largest identity was found with Tomato yellow spot virus (74\%) (1). Ref.: (1) Ferreira, S.S. et al. Plant Pathology 59: 221. 2010.

\section{*Pavonia spp. (Swampmallows) Malvaceae \\ Begomovirus \\ Pavonia yellow mosaic virus (PavYMV) \\ Pavonia mosaic virus (PavMV)}

Pavonia sp. with mosaic symptoms were found in Albuquerque and Corumbá, MS. Molecular studies indicated that these plants were infected by two new begomovirus species, designated PavYMV and PavMV (1).

Ref.: (1) Pinto, V.B.et al. Arch.Virol. 161: 735. 2016.

\section{Infectious chlorosis of malvacea complex (ICMC)}

Mosaic bearing swampmallows plants were found in Araruama, RJ and Louveira, SP. The causal agent was considered as part of the infeccious chlorosis of malavacea complex (1).

Ref.: (1) Silberschmidt,K. \& Tommasi, L.R. Ann.Acad.Bras.Cien. 27: 195. 1955.

\section{*Pelargonium hortorum L.H. Bailey (Zonal geranium) Geraniaceae Cilevirus \\ Cilevirus unidentified}

Ringspots on the leaves of $P$. hortorum were noticed in the state of São Paulo, associated with infestation by Brevipalpus mites. Electron microscopy indicated the occurrence of cytopathic effects typical of cilevirus in tissues of the lesions (1).

Ref.: (1) Nogueira et al. Summa Phytopathol. 29: 278. 2003.

\section{*Pennisetum purpureum Schum. (Elephant grass) Poaceae}

Potyvirus

Johnson grass mosaic virus (JGMV)

Elephant grass plants were found showing mosaic symptoms in the state of Bahia. Biological and molecular assays detected JGMV in these plants (1). A complete genome sequence of this isolate of JGMV was obtained (2). Maize was infected by a JGMV isolate obtained in the state of Minas Gerais (3). Ref.: (1) Silva, K.N. et al. Plant Dis. 97: 1003. 2013; (2) Silva, K.N. et al. Arch.Virol. 161: 1981. 2016; (3) Souza, J.M. et al. Virus Rev. \& Res. 21: 123. 2016.

Potyviridae unclassified

Elephant grass mosaic virus (EGMV) 
Symptoms of mosaic were observed in elephant grass from a pasture in Sta. Helena, PR associated with infection by a potyvirus. This virus was mechanically transmissible to elephant grass and some other poaceae hosts, but not by aphids, suggesting that it does not belong to the genus Potyvirus. The virus, named EGMV was purified and a specific antiserum was produced. Serological assays could not demonstrate relationship with other poaceae potyviruses (1).

Ref.: (1) Martins, C.R.F. \& Kitajima, E.W. Plant Dis. 77: 726. 1993

\section{*Peperomia caperata Yunck (Emerald ripple peperomia) Piperaceae \\ Cucumovirus \\ ${ }^{*}$ Cucumber mosaic virus (CMV)}

CMV was detected infecting $P$ caperata in Lavras, MG, showing deformed apical leaves, chlorotic or mottled leaves, and partial vein necrosis. Identification was made through biological, serological assays and electron microscopy (1).

Ref.: (1) Boari, A.J. et al. Fitopatol. Bras. 21: 422.1996

\section{*Peperomia obtusifolia A.Dietrich (Baby rubberplant, Pepper face) Piperaceae}

Tymovirus

Eggplant mosaic virus (EMV)

Concentric reddish rings were noticed in baby rubberplant growing in a residential garden in the city of São Paulo, SP. Further works indicated that the causal agent was a mechanically and chrysomelid beetle- transmissible virus. Electron microscopy suggested that this virus was a tymovirus, and serological assays revealed that it was an isolate of EMV. Molecular assays confirmed this identification (1). Ref.: (1) Rivas, E.B. et al. Summa Phytopathol. 29: 313. 2003.

\section{*Petroselinum sativum L. (Parsley) Apiaceae}

Potyvirus

Cerely mosaic virus (CeMV)

Natural infection of parsley by CeMV was registered in the state of São Paulo, resulting in yellow mosaic symptoms. Identification of the virus was made by biological and serological assays, and electron microscopy (1).

Ref. : (1) Novaes, Q.S. et al. Fitopatol.bras. 22:340. 1997.

\section{*Petunia $x$ hybrida Hort. Ex-Vilm. (Petunia) Solanaceae \\ Orthotospovirus \\ Orthotospovirus unidentified}

Chlorotic spots and vein clearing was noticed in petúnia plants in São Paulo, SP, associated with an unidentified Orthotospovirus (1).

Ref.: (1) Alexandre, M.A.V. et al. Rev. Bras. Hortic. Ornamental 11: 49-57, 2005.

\section{Caulimovirus}

Cauliflower mosaic virus (CaMV)

The caulimovirus-like virus found in petunia co-infected with PetVB from Gramado, RS, was tentatively considered as an isolate of Petunia vein banding virus, but later identified as CaMV, based on serological assays $(2,3)$.

Ref.: (1) Alexandre, M.A.V. et al. Summa Phytopathol. 19: 48. 1993; (2) Fitopatol. Bras. 22: 330, 1997; (3) Virus Reviews \& Research 2: 189, 1997.

Tymovirus

\section{Petunia vein banding virus (PetVBV)}

Petunia plants collected in Gramado, RS, showing vein banding, mosaic and blistering revealed to be co-infected by a caulimoviruslike and tymovirus-like viruses, based on electron microscopy. Vein banding symptoms was attributed to the tymovirus, which was characterized as a new species and named PetVBV (1).
Ref.: (1) Alexandre, M.A.V. et al. Plant Dis. 84: 739-742. 2000.

Tobamovirus

\section{Tobacco mosaic virus (TMV)}

Symptoms of yellow mosaic and leaf deformation was observed in petunia plants sampled in the state of São Paulo. Causal agent was transmitted mechanically to Petunia integrifolia, Gomphrena globosa, tomato and Zinnia elegans. Nucleotide sequence of the coat protein indicated that these petunia were nfected by an isolate of TNV (1). Ref.: (1) Alexandre, M.A.V. et al. J. Phytopath. 148: 601-607, 2000.

\section{*Pfaffia glomerata (Spreng.) Pedersen (Brazilian ginseng) Amaranthaceae \\ Potyvirus \\ Pfaffia mosaic virus (PfMV)}

Pfaffia glomerata is cultivated for its pharmaceutical properties, and some plants of the germplasm collection kept at the Universidade Estadual Norte Fluminense in Campos de Goitacazes, RJ, exhibited mosaic symptoms. Further works demonstrated that the condition was a result of infection by a potyvirus with restricted host range and transmitted by aphids. This potyvirus was purified and a specific antiserum, produced. Analysis of the genome sequence indicated that it was a distinct species of potyvirus, and named PfMV (1). (1).

Ref. : (1) Mota, L.D.C. et al. Plant Pathology 53: 368. 2004.

\section{*Phaseolus lunatus L. (Lima bean) Fabaceae \\ Comovirus}

Cowpea severe mosaic virus (CPSMV)

One of the seeds of Lima bean, from Jataí, GO produced mild mosaic symptoms in primary leaves, upon germination. CPSMV, serotype IV, was identified as the causal agent (1). CPMSV was also found infecting Lima bean associated with mosaic symptoms in the state of Piauí (2).

Ref.: (1) Costa, C.L. et al. Fitopatol. Bras. 16: XXV. 1991; (2) Beserra Jr., J.E.A. et al. Trop.Plt.Pathol. 41 (supl.). 2016.

Cucumovirus

\section{Cucumber mosaic virus (CMV)}

Mosaic induced by CMV infection of Lima bean was observed in the state of Ceará (1).

Ref.: (1) Lima, J.A.A. \& Santos, C.D.G. Fitopatol.bras.10: 304. 1985*. Potyvirus

\section{Cowpea aphid-borne mosaic virus (CABMV)}

Occurrence of Lima bean plants possibly infected by CABMV was registered in Brasília, DF, showing yellow mosaic symptoms on leaves. Bean cv. 'Rosinha' was experimentally infected by this isolate and found to be infected by a potyvirus (1). A similar case of detection of CABMV in symptomatic Lima beans was registered in Itambé and Terezinha, PE, the virus being identified by biological and serological assays (2).

Ref.: (1) Costa, C.L. et al. Fitopatol. Bras. 16: XXVII. 1991/ (2) Andrade, G.P. et al. Fitopatol.bras. 26: 511. 2000.

Begomovirus

\section{Bean golden mosaic virus (BGMV)}

BGMV infecting Lima bean was first recorded in the state of São Paulo, a situation quite common in commercial plantations of this legume, resulting symptoms very similar to that caused on beans by this virus. It is whitefly borne (1). Lima bean infection by BGMV was also reported in the state of Ceará (2), Alagoas and Pernambuco (3). Ref.: (1) Ref.: Costa, A.S. et al. Anais I Simp.Bras.Feijão (Campinas). P. 305. 1972; (2) Lima, J.A.A. Fitopatol.bras. 10: 301. 1985; (3) Silva, S.J.C. et al. Fitopatol.bras. 31 (supl): S249. 2006. 


\section{*Phaseolus vulgaris L. (Common bean) Fabaceae Cytorhabdovirus \\ Cytorhabdovirus unidentified}

A yet to be characterized cytorhabdovirus was found by NSG in transgenic bean variety, resistant to BGMV, which was exhibiting mosaic symptoms in an experimental area in the state of Goiás, coinfecting the plant with CPMMV and BRMV and endornavirus $(1,3)$. This cytorhabdovirus was successfully transmitted to bean, soybean and cowpea by the whitefly Bemisia tabaci (2).

Ref.: (1) Alves-Freitas, D.M.T. et al. Virus Rev.\&Res. 20 (supl): 42. 2016; (2) Lima, B.P. et al. Res.397, Cong.Bras.Virol., 2017; (3) AlvesFreitas, D.M.T. et al. Viruses 11:90 .2019.

Orthotospovirus

\section{Bean necrotic mosaic virus (BNMV)}

BNMV is of rare occurrence. First described in the state of São Paulo in the 1950's, and later in Distrito Federal (5) and in the state of Rio de Janeiro (4). Causal virus was identified as an Orthotospovirus as deduced by electron microscopy (3), but considered distinct from until known species of Orthotospovirus, because upon mechanical inoculation on bean cv. 'Manteiga', caused systemic infection rather than local lesions (2). This virus causes mosaic symptoms resembling those caused by Bean common mosaic virus, but without blistering or rugosity. The systemic leaf necrosis is formed by small spots and rings resembling injuries caused by friction. Pods might become spotted and infected plants have lower yields (1). With the advent of molecular techniques its genome was completely sequenced and characterized as a new species among Orthotospoviruses, with some similarities with another Orthotospovirus characterized almost simultaneously in the USA, associated with vein necrosis in soybean (6).

Ref.: (1) Costa, A.S. Bragantia 16: XV. 1957; (2) Costa, A.S. et al. Anais I Simp. Bras. Feijão (Campinas). P. 305. 1972; (3) Kitajima, E.W. \& Costa, A.S. Ciencia e Cultura 25: 1174.1973; (4) Kitajima, E.W. et al. Fitopatol.bras. 9: 607. 1984; (5) Costa, C.L. et al. Fitopatol. bras. 11: 370. 1986; (6) Oliveira, A.S. et al., Virus Gene 43: 385. 2011 Comovirus

\section{Bean rugose mosaic virus (BRMV)}

Field infection of bean plants by BRMV is rare, and first description was made in the state of São Paulo (1). Symptoms of vein banding forming symmetric figures appear on the leaves, without rugosity or wrinkling, and plants do not seem seriously affected. BRMV as other comoviruses occurs in high concentration in the tissues, the virions frequently aggregating in crystalline formation in the cytoplasm (2). It is transmitted in the field by by chrysomelid beetles and experimentally, without difficulty, by mechanical means; no seed transmission was observed (1). BRMV has been purified and specific antiserum is available. Immunological assays clearly indicated that Brazilian isolates of BRMV is essentially identical to those found in Central America (4). It was found infecting bean plants in Distrito Federal (3), and in the states of Paraná (6), Goiás (7) and Minas Gerais (8). Precocious infection may reduce yields up to $60 \%$ (5).

Ref.: (1) Costa, A.S. et al. Anais I Simp.Bras.Feijão (Campinas). P. 305. 1972; (2) Camargo, I.J.B. et al. Fitopatol.bras. 1:207. 1976; (3) Kitajima, E.W. et al. Fitopatol.bras. 5: 408. 1980; (4) Lin, M.T. et al. Fitopatol.bras. 6: 293.1981; (5) Sperandio, C.A. Diss.Mestr., UnB, 57p. 1982; (6) Bianchini, A. et al. Fitopatol.bras. 10: 307. 1985; (7) Anjos, J.R.N. et al., Fitopatol.bras. 11: 391. 1986; (8) Torres, L.B. et al. Virus Rev.\& Res. 8: 195.2003.

\section{Cowpea severe mosaic virus (CPSMV)}

CPSMV was found infecting bean, producing vein clearing and systemic chlorotic spots, blistering of young leaves in Distrito Federal. This virus was identified as CPSMV by serology, as being serotyp IV (1).

Ref.: (1) Cupertino, F.P. et al. Fitopatol.bras. 7: 275. 1982.

\section{Carlavirus}

Cowpea mild mottle virus (CPMMV)

CPMMV was first described infecting cv. 'Jalo'bean plants in Campinas, SP and Londrina, PR, causing symptoms defined as angular mosaic on leaves. In younger leaves, infection results in vein chlorosis or interveinal chlorosis, followed by green vein banding. In older leaves, yellow mosaic angular in shape, limited by veins is observed. The causal virus was identified as a carlavirus transmitted by the whitefly Bemisia tabaci, and identified as an isolate of CPMMV (1, 2). Serological assays confirmed this diagnosis (3). It has been purified (4). CPMMV was detected in bean fields of the state of Pernambuco (5). Sensitive qRT-PCR assays demonstrated seed transmission of CPMMV in experimentally infected bean plants (6).

Ref.: (1) Costa, A.S. et al. Res. $1^{\circ}$ Sem.Pragas e Doenças Feijoeiro.p.8. 1980; (2) Costa, A.S. et al. Fitopatol.bras. 8: 325.1983; (3) Gaspar, J.O. et al. Fitopatol.bras 10: 195. 1985; (4) Gaspar, J.O. et al. Fitopatol. bras. 18: 554. 1993; (5) Lamas, N.S. et al. Plant Dis. 101: 1828. 2017; (6) Felix, GP et al. Res.29 Cong.Bras.Virol. 2019.

\section{Cucumovirus}

\section{Cucumber mosaic virus (CMV)}

Smooth and small leaves, showing mosaic symptoms were observed in bean plants from Cruzeiro d'Oeste, PR. Causal agent of this condition was identified as an isolate of CMV (1). This virus was also reported infecting bean in the state of São Paulo, causing vein banding and leaf malformation, without affecting growth (2). CMV infection of bean plants was also recorded in Caruarú, PE (3).

Ref. (1) Silberschmidt, K. O Biológico 29: 117. 1963; (2) Costa, A.S. et al. Fitopatologia (Lima) 11: 10. 1976; (3) Costa, C.L. et al. Fitopatol.bras. 11: 359. 1986.

Ilarvirus

\section{Tobacco streak virus (TSV)}

Red knot of bean plants is a rare disease, and caused by a Brazilian isolate of TSV. It was reported in the state of São Paulo. Infected plants exhibit several kinds of necrosis (points, rings, streaks) on leaves, petioles and stem. A reddening occurs in the nodes and may cause the death of the plant (1).

Ref.: (1) Costa, A.S. et al. Anais I Simp.Bras.Feijão (Campinas). P. 305. 1972.

Alphaendornavirus

Phaseolus vulgaris endorna virus 1 (PvEV-1) e 2 (PvEV-2)

NSG technique revealed the presence of these two endornaviruses in transgenic, BGMV resistant bean cultivars, in an experimental field in the state of Goiás. These plants were also co-infected by BRMV and CPMMV (1).

Ref.: (1) Alves-Freitas, D.M.T. et al. Virus Rev. \& Res. 20 (2): 42. 2016.

\section{Potyvirus}

\section{Bean common mosaic virus (BCMV)}

The first formal description of bean infection by BCMV was made in experimental fields of bean in the Instituto Agronomico, Campinas, SP, in 1936. Most of bean varieties being studies revealed susceptibility (1). BCMV causes on infected plants conspicous mosaic, commonly with chlorotic areas between veins and wrinkling of leaves. This virus is seed and aphid borne, and experimentally is mechanically transmissible. Hypersensitive bean lines which are practically immune tp BCMV, if exposed to a very high inoculum potential, may show upon infection, tip necrosis followed by death (2). BCMV occurs in most of bean producing areas $(1,3,5)$. A BCMV recovered from Senna occidentalis induce aracnoid yellow spots on inoculated leaves and also upon systemic infection. It was not seed-borne (4).

Ref.: (1) Costa, A.S. \& Forster, R. O Biologico 7: 177. 1941. (2) Costa, A.S. et al. Res.1 ${ }^{\circ}$ Simp.Feijao. 1971; (3) Siqueira,O. et al. Rev.Bras. Fitopat. 4: 69. 1971; (4) Costa, A.S. et al. Anais I Simp.Bras.Feijão 
(Campinas). P. 305. 1972; (5) Boari, A.J. \& Figueira, A.R. Fitopatol. bras. 17: 178. 1992.

\section{Bean yellow mosaic virus (BYMV)}

First mention of BYMV was made in a cytological study, comparing cytopathic effects of bean leaf tissues infected by BCMV and BYMV. BYMV induces a characteristic crystalline nuclear inclusion (2), but the disease has been noted together with dwarf mosaic in 1941 (1). Mosaic caused by BYMV is of bright yellow, not as much as golden mosaic, roughness and wrinkling of leaves, smaller size of infected plant. Infection by BYMV is quite rare in fields. It may infect naturally plants as groundnut, soybean and gladiolus. There are severe isolates as those necrotic type found in groundnut (3).

Ref.: (1) Costa, A.S. \& Forster, R. O Biológico 7: 177. 1941; (2) Camargo, I.J.B. et al. Bragantia 27: 409. 1968; (3) Costa, A.S. et al. Anais I Simp.Bras.Feijão (Campinas). P. 305. 1972.

\section{Cowpea aphid-borne mosaic virus (CABMV)}

Natural infection of bean cv. 'BT2' by CABMV-P, was reported in the state of Minas Gerais, resulting in mosaic symptoms, close to a passion flower field. This virus was identified by biological and serological assays (1).

Ref.: (1) Maciel, S.C. et al. Summa Phytopathol. 30: 110.2004.

Potyvirus unidentified

Bean plants from Tremembé, SP, were found showing mosaic in young and médium leaves, formed by irregular chlorotic plates. It was considered that the disease was caused by a potyvirus of the Pisum group (1).

Ref.: (1) Silberschmidt, K. \& Nobrega, N.R. O Biologico 8: 129. 1943. Sobemovirus

\section{Southern bean mosaic virus (SBMV)}

SBMV was first detected in Brazil, infecting bean cv. 'Rico 23' causing mosaic symptoms, in Brasília, DF. Identification was made by biological and serological assays, complemented by electron microscopy (1). Its transmission by chrysomelid beetle Diabrotica speciosa (Germ) and Cerotoma arcuata (Oliv.) was demonstrated (2). SBMV was found infecting commercial bean fields in the state of Paraná (3). Genome sequences comparisons indicated that an isolate of SBMV from the state of São Paulo was essentially similar to USA isolate $(4,5)$.

Ref.: (1) Cupertino, F.P. et al. Plant Dis. 66: 741. 1982; (2) Silveira Jr., W.G. et al. Fitopatol. bras. 8: 625. 1983; (3) Gasparin, M.D.G. et al. Fitopatol.bras. 27: S205. 2002; (4) Moreira, A.E. \& Gaspar, J.O. Fitopatol.bras. 27: 292. 2002.(5) Ozato Jr., T. et al. Virus Rev. \& Res. 11 (supl):190. 2006.

Begomovirus

\section{Bean golden mosaic virus (BGMV)}

BGMV was described around 1960's in the state of São Paulo as causing marginal disease in bean fields (1). However it became the limiting factor for common bean production in the next decade, as a consequence of the rapid expansion of the soybean culture. Soybean is an excelent host for the whitefly Bemisia tabaci, which freely migrated to nearby bean fields, spreading BGMV, destroying in several occasions entire bean fields resulting in significative losses in most of the bean producing states (3). Brazil became from bean exporter to importer in few years. BGMV-infected bean plants show conspicuous golden yellow mosaic or yellow net on leaves, and bean plants if infected early, remains stunted without producing bean grains. No varietal resistance exists. It is not mechanically transmissible as a Central America isolate. However, transmission by biolistic means was successful (5). Many cultivated or wild legumes may serve as source of inoculum (2). Control has been made through the use of tolerant varieties and zoning of the culture (far from soybean fields, or planted offseason of soybean) (4). Experimentally it was shown that infection by BGMV promotes effective cross-protection against infection by
AbMBV (3). Bean lines more resistant have been selected (5). Genetic engineering has produced transgenic bean plants immunes to BGMV, through the expression of some viral genes, and commercial lines are ready to be distributed (6).

Ref.: (1) Costa, A.S. FAO Plant Protection Bull. 13: 1. 1965; (2) Costa, A.S. et al. Anais I Simp.Bras.Feijão (Campinas). P. 305. 1972; (3) Costa, C.L. \& Cupertino, F.P. Fitopatol. bras. 1: 18. 1976; (3) Costa, A.S. Summa Phytopathol. 9: 53. 1983; (4) Vicente, M. et al. O Biológico 51: 147. 1985; (5) Bianchini, A. Fitopatol.bras. 19: 329. 1994; (6) Aragão, F.J.L. et al. J.Biotechnology 166: 42. 2013.

Euphorbia yellow mosaic virus (EupMV)

Infection of bean plants by EuYMV is a rare event. It was first reported in the state of São Paulo. Leaf distortion caused by chlorotic spots result from natural infection of EupMV (1).

Ref.: Costa, A.S. FAO Plant Protection Bull. 13: 1. 1965.

\section{Macroptilium yellow spot virus (MaYSV)}

Isolates of MayYSV were found infecting bean plants, causing a golden mosaic, and were characterized by biological and molecular means in the states of Pernambuco, Sergipe and Alagoas (1).

Ref.: (1) Almeida, K.C. et al. Abst.7th Intl.Geminivirus Symp. P.60. 2013.

Sida micrantha mosaic virus (SimMV)

A variant of SmMV was found causing golden mosaic symptoms on bean in the state of Goiás (1).

Ref: (1) Fernandes, N.A.N. et al. Trop Plt Pathol 34 (supl): S270. 2009. Tomato severe rugose virus (ToSRV)

A case of asymptomatic infection of bean plants by ToSRV was observed in commercial field in Central Brazil. Detection of this virus was made by PCR. Agroinfection of infectious clones of ToSRV also caused asymptomatic infection of bean (1).

Ref.: (1) Macedo, M.A. et al. Plant Dis. 101: 261. 2017.

\section{Infectious chlorosis of malvaceae complex (ICMC)}

First report of bean infection by begomoviruses was reported in the state of São Paulo in the 1940's (1). Affected young plants were stunted and showed basal leaves in a dark green color, and the younger leaves became smaller occasionally with mosaic symptoms and curved down. Infection of adult plants causes mosaic, wrinkling and reduction in size of leaves and size of internodes. Seed transmission was observed but mechanical transmission was not achieved. The causal agent was considered as a member of ICMC, spread by the whitefly Bemisia tabaci (2-3). Natural infection of bean by ICMS was estimated in $2-5 \%$ (4). A witches' broom symptoms were observed associated with infection by this begomovirus (5).

Ref.: (1) Costa, A.S. \& Forster, R. O Biologico 7: 177. 1941; (2) Costa, A.S. Phytopathol. Zeit. 24: 97. 1955; (3) Costa, A.S. FAO Plant Protection Bull. 13: 1. 1965; (4) Costa, A.S. et al. Anais I Simp.Bras. Feijão (Campinas). P. 305. 1972; (5) Costa, A.S. Summa Phytopathol. 9: 76.1983.

\section{*Phenax sonneratii (Poir) Wedd. (Asian ghostweed) Urticaceae Begomovirus \\ Infectious chlorosis of malvaceae complex (ICMC)}

Vein clearing and angular chlorotic spots were observed in leaves of $P$. sonneratii growing nearby the city of Santos, SP. The symptoms could be graft transmitted and the causal agent was identified as a possible member of the group of ICMC (1).

Ref.: (1) Silberschmidt, K. Phytopathology 38: 395. 1948.

\section{*Physalis angulata L. (Cutleaf groundcherry) Solanaceae Orthotospovirus \\ Zucchini lethal chlorosis virus (ZLCV)}

During a survey of viruses present in weeds surrounding cucurbit 
fields in the state of Tocantins, ZLCV was found naturally infecting $P$. angulata in Formoso do Araguaia (1).

Ref.: (1) Aguiar, R.W.S. et al. Planta Daninha 36: :e018171593. 2018. Crinivirus

\section{Tomato chlorosis virus (ToCV)}

P. angulata plants showing interveinal chlorosis on their leaves were found in Capão Bonito, SP. These symptoms could be reproduced by whitefly transmission assays and RT-PCR confirmed the infection by ToCV (1).

Ref.: (1) Fonseca, M.E.N. et al. Plant Dis. 97: 692. 2013.

Potyvirus

Papaya ringspotvirus $W$ (PRSV)

Watermelon mosaic virus (WMV)

Zucchini yellow mosaic virus (ZYMV)

PRSV-W, WMV and ZYMV were found infecting $P$. angulata in Lagoa da Confusão, TO, during a survey for cucurbit viruses in spontaneous vegetation (1).

Ref.: (1) Aguiar, R.W.S. et al. Planta Daninha 36: :e018171593. 2018.

Potato virus virus (PVY)

A case of infection of $P$. angulata by PVY was reported in samples collected at Mairiporã, SP (1).

Ref.: (1) Chaves, A.L.R. et al. Summa Phytopathol 36(supl): 047. CDRom.2010.

Tobamovirus

\section{Tobamovirus unidentified}

During a plant virus survey in the Amazon basin, P. angulata plants, part of the spontaneous vegetation nearby Manaus, AM, were found showing conspicuous mosaic symptoms. Electron microscopy detected possible infection by a tobamovirus, which remains unidentified (1).

Ref.: (1) Cupertino, F.P. et al. Fitopatol.bras. 6: 532. 1981.

Begomovirus

\section{Begomovirus unidentified}

Mottling was observed on $P$. angulata plants in an experimental field of Embrapa Hortaliças, Brasília, DF. A still unidentified begomovirus was detected by PCR tests (1).

Ref.: (1) Boiteux, L.S. et al. Fitopatol.bras. 28 (supl.): S2437. 2003.

\section{*Physalis floridana Rydberg. Solanaceae \\ Polerovirus \\ Potato leafroll virus (PLRV)}

An isolate of PLRV, which causes tomato yellow top, was recovered from chlorotic P. floridana plants. These plants may serve as virus reservoir in the epidemiology of PLRV in tomato crops (1).

Ref.: (1) Costa, A.S. \& Carvalho, A.M.B. Coopercotia 148 fev.62,p.34. 1962.

\section{*Physalis peruviana L. (Peruvian groundcherry) Solanaceae Orthotospovirus \\ Groundnut ringspot virus (GRSV)}

P. peruviana plants showing chlorotic and ringspots on their leaves were found in an experimental field in Piracicaba, SP. GRSV was identified as the causal agent based on biological, morphological, serological and molecular assays. Presence of the thrips Frankliniella schultzei, its possible vector, on diseased plants was determined (1). GRSV was also found infecting P. peruviana in Central Brasil (2). Ref.: (1) Esquivel, A.F. et al. Plant Dis. 102 (7): 1469. 2018; (2) Lima, M.F. et al. Res. 29 Cong.Bras.Virol. 2018.

\section{Tomato chlorotic spot virus (TCSV)}

Mosaic symptoms were observed in a commercial plantation of Peruvian groundcherry in Santa Maria, RS. The causal agent was identified as TCSV (1).

Ref. (1) Eiras, M. et al. New Disease Rept. 25: 25. 2012.

Potyvirus

\section{Potato virus Y (PVY)}

P. peruviana was found infected by PVY in the state of Santa Catarina (1).

Ref.: (1) Gonçalves, M.J. et al. Trop.Plt.Pathol. 39 (supl): CD Rom. 2014.

Sobemovirus

\section{Velvet tobacco mottle virus (VTMoV)}

P. peruviana plants with mosaic, yellowing, leaf crinkling and fruit deformation were noticed in commercial fields in the state of Santa Catarina. Biological, serological and molecular assays identified the causal agent as an isolate of VTMoV. Infection of $P$. peruviana by VTMoV promoted yield losses and affected fruit quality (1). Ref.: (1) Gorayeb, E.S. et al. Res. 29 Cong.Bras.Virol. 2018.

\section{*Physalis sp., Solanaceae}

Begomovirus

Physalis yellow spot virus (PhYSV)

A begomovirus was found infecting Physalis sp. in the state of Alagoas, possibly a distinct species and named PhYSV, but further characterization is still pendent (1).

Ref.: (1) Nascimento, L.D. et al. Trop.Plt.Pathol. 38 (supl.): 195. 2013.

\section{*Phytolacca decandra L. (Pokeweed) Phytolaccaceae}

Potyvirus

Potato virus Y (PVY)

Natural infection of field pokeweed plants by PVY was observed in the state of Minas Gerais. No reference to symptoms was made (1). Ref.: (1) Oliveira, C.D. et al. Fitopatol.bras. 21: 427. 1996.

\section{*Piper callosum Ruiz \& Pav. Piperaceae \\ Dichorhavirus \\ Dichoravirus unidentified}

P. callosum plants with chlorotic spots on their leaves were found nearby Manaus, AM. Electron microscopy revealed cytopathic effects similar to those caused by dichorhaviruses in tissues of lesions (1). Ref.: (1) Rodrigues, J.C.V. et al. Trop.Plt.Pathol 33: 12. 2008.

\section{*Piper nigrum L. (Black pepper) Piperaceae Dichorhavirus \\ Dichorhavirus unidentified}

Chlorotic spots were observed on the leaves of some cultivated black pepper plants in Tome-Açú, PA. Electron microscopy revealed cytopathic effects similar to those caused by dichorhaviruses (1). Ref.: (1) Yamashita, S. et al. Summa Phytopathol. 30: 68. 2004.

\section{Cucumovirus}

\section{Cucumber mosaic virus (CMV)}

Black pepper plants cultivated in the state of Pará were found with mosaic symptoms on their leaves, reduced internode size, stunting, smaller and deformed bunches and yield reduction. The causal agent was identified as an isolate of CMV. Tha aphid Aphis gossypii was able to experimentally transmit CMV to black pepper. $(1,2)$. Later, similar problems were found in black pepper planted in the state of São Paulo (3) and Espirito Santo (ES). A satellite RNA was found associated with CMV found in black pepper in ES (5).

Ref.:(1) Caner, J. O Biológico 35: 185. 1969; (2) Costa, A.S. et al. IPEAN, Ser. Fitotecnia 1: 1. 1970; (3) Caner, J. \& Ikeda, H. O Biológico 38: 93. 1972; (4) Maciel-Zambolin, E. et.al. Fitopatol.bras. 15: 220. 1990; (5) Boari, A.J. et al. Fitopatol.bras. 25: 143. 2000.

\section{Badnavirus}

\section{Piper yellow mottle virus (PYMoV)}

Some black pepper plants maintained in the germplasm collection at Embrapa Amazonia Oriental, Belém, PA, showed chlorotic mottle and vein clearing symptoms on their leaves. Electron microscopy 
revealed badnavirus like particles in the tissues (1). Molecular assays confirmed that this badnavirus is PYMoV, which is mealybugtransmitted (2). The mealybug Planococcus minor experimentally transmitted PYMoV to healhy black pepper plants (3).

Ref.: (1) Albuquerque, F.C. et al. Fitopatol.bras. 25: 36. 1999; (2) Brioso, P.S.T. et al. Fitopatol.bras. 25: 438. 2000; (3) Sousa, C.M. et al Virus Rev.Res. 15 (supl):309. 2010.

\section{*Pisum sativum L. (Pea) Fabaceae Cytorhabdovirus \\ Cythorhabdovirus unidentified}

Pea plants with chlorotic mottle and reduced growth were found in Itapecerica da Serra, SP. Co-infection of an unidentified potyvirus and cytorhabdovirus was verified. The latter was mechanically transmitted to Nicotiana glutinosa and Datura stramonium. No further works were made to complete the identification of these viruses (1).

Ref.: (1) Caner, J. et al. Summa Phytopathol. 2: 264.1976.

Orthotospovirus

\section{Goundnut ringspot virus (GRSV)}

Pea plants with apical chlorosis, foliar necrosis and deformation were found in Brasília, DF. Causal agent was identified as an isolate of GRSV based on serological and molecular assays (1).

Ref,: (1) Fontes, MG et al. Plant Dis. 102: 457. 2018.

Tomato spotted wilt virus (TSWV)

In Brasília, DF, TSWV was found infecting pea plants causing tip blight and brown spots on the pod; lower leaves exhibited mottling, and necrotic streaks appeared on stems. Symptoms were more severe on the cv. 'Triofin' than on 'Mikado' (1).

Ref.: (1) Reifschneider, F.J.B. et al. Trop.Pest Managem. 35: 304.1989. Cucumovirus

\section{Cucumber mosaic virus (CMV)}

Pea plants were found in a commercial cv. 'Mikado' pea plantation in Dourados, MS, showing mosaic and rosette symptoms. Biological, serological and molecular assays, and electron microscopy, revealed that the causal agent was an isolate of CMV, similar to that found infecting black pepper (1).

Ref.: (1) Dusi, A.N. et al. Fitopatol.bras 17: 286. 1992.

Potyvirus

Bean yellow mosaic virus (BYMV)

Mosaic symptoms were observed in cultivated pea in the state of Paraná, associated with infection by BYMV(1).

Ref.: (1) Lima, M.L.R.Z.C. et al. Fitopatol.bras. 9: 403. 1984.

Bidens mosaic virus (BiMV)

Occurrence of a yellow mosaic was noticed in a commercial plantation of pea cv. 'Torta de Flor Roxa' in Brasília, DF. Causal agent was identified as an isolate of BiMV (1).

Ref.: Nagata, T. et al. Fitopatol. Bras. 20: 473. 1995.

Pea seed-borne mosaico virus (PSbMV)

PSbMV was found infecting pea plants cv. 'Triofin', causing mosaic and leaf deformation in Dourados, MS and Brasília, DF. Identification was based on biological and serological asaays, and electron microcopy (1)

Ref.: (1) Dusi, A.N. et al. Fitopatol. bras. 19: 219. 1994.

\section{*Plumbago auriculata Lam. (Blue plumbago) Plumbaginaceae Cilevirus}

\section{Cilevirus unidentified}

Blue plumbago plants showing chlorotic spots on leaves were observed in a residential garden in Atibaia, SP, associated with Brevipalpus mite infestation. Electron microscopy revealed cytopathic effects similar to those caused by cilevirus in tissues of the lesions, but causal virus still reamains unidentified (1).

Ref.: (1) Freitas-Astua, J. et al. Summa Phytopathol. 30: 80. 2004.

\section{*Pogostemum patchouly Pellet (Patchouli) Lamiaceae Cytorhabdovirus Cytorhabdovirus unidentified}

A possible Cytorhabdovirus was detected by electron microscopy in patchouli plants with mosaic symptoms, in a germplasm collection of Seção de Plantas Aromáticas, Instituto Agronomico, Campinas, SP. Similar finding was made in a sample collected in the state of Sergipe, in patchouli clones received from Embrapa Amazonia Oriental (2).

Ref.: (1) Kitajima, E.W. \& Costa, A.S. Fitopatol.bras. 4: 55. 1979; (2) Boari, AJ et al. Fitopatol.bras. 31 (supl): S322. 2006.

Nucleorhabdovirus

\section{Nucleorhabdovirus unidentified}

Electron microscopic analysis detected a possible infection by so far unidentified nucleorhabdovirus in patchouli plants collected in the state of São Paulo, showing chlorosis and leaf distortion (1).

Ref.: (1) Lombardi, R. \& Galleti, S.R. Summa Phytopathol. 34 (supl.): S68-69. 2008.

Potexvirus

\section{Patchouli X virus (PatVX)}

Some patchouli plants with mosaic symptoms from the germplasm collection of Seção de Plantas Aromáticas, Instituto Agronomico, Campinas, SP, were found to have suffered a mixed infection by unidentified poty- and cytorhabdovirus, and by a potexvirus. This potexvirus, possibly causing latent infection, was characterized and found to be a new species, based upon partial sequences of the coat protein and named PatVX. It might be related to Argentine plantago virus. Mechanically inoculated tobacco and Datura stramonium became systemically infected, while Gomphrena globosa reacted with local lesions $(1,2)$.

Ref.: (1) Meissner Fo., P.E. et al. Fitopatol.bras.22: 569. 1997; (2) Ann.Appl.Biol. 141: 267. 2002.

Potyvirus

\section{Potyvirus unidentified}

Unidentified potyvirus was detected in patchouli, from germplasm collection of Seção de Plantas Aromáticas, Instituto Agronomico, Campinas, SP, and samples from Belém, PA, sometimes in coinfection with other viruses (1). It was also detected in plants collected in the state of Sergipe (2). It seems to be an isolate of BiMV (E.W. Kitajima, pers.comm.).

Ref.: (1) Gama, M.I.C.S. et al. Fitopatol.bras. 4: 113. 1979; (2) Boari, A.J. et al. Fitopatol.bras. 31 (supl): S322. 2006.

Alphanecrovirus

\section{Tobacco necrosis virus (TNV)}

TNV was found in some patchouli samples from the germplasm collection of Seção de Plantas Aromáticas, Instituto Agronomico, Campinas, SP, apparently in an asymptomatic infection (1).

Ref.: (1) Gama, M.I.C.S. et al. Phytopathology 72: 529. 1982.

Tobravirus

\section{Pepper ringspot virus (PepRSV)}

Virus-free plants of patchouli were obtained by tissue culture. Some of them were planted on unsterilized soils in the experimental field of the Universidade de Brasília, DF. Chlorotic rings and yellow lines appeared in some of these plants, and the causal agent was identified as PepRSV. Probably natural infection of this virus was mediated by a nematode vector (1).

Ref.: (1) Gama, M.I.C.S. et al. Fitopatol.bras. 8: 395. 1983.

\section{*Porophyllum ruderale (Jacq.) Cass. (Bolivian coriander) Asteraceae \\ Nucleorhabdovirus \\ Nucleorhabdovirus unidentified \\ Bolivian coriander plants with yellow mottle symptoms were found in}


Nova Odessa, SP. Electron microscopy detected a nucleorhabdovirus, which remains unidentified (1).

Ref. (1) Alves, A.C.C.N. et al. Summa Phytopathol. 34: 375. 2008.

\section{*Portulaca oleracea L. (Purslane) Portulacaceae Orthotospovirus \\ Orthotospovirus unidentified}

Purslane is a common invasive weed in Brazil, and some plants growing in the state of São Paulo were observed showing chlorotic and necrotic on their leaves, associated to stunting. Recovery assays demonstrated the presence of an unidentified Orthotospovirus, indicating that these infected purslane plants may serve as virus reservoir for cultivated plants (1). Similar finding is reported in the state of Paraná (2).

Ref.: (1) Costa, A.S. \& Carvalho, A.M.B. Bragantia 19: XXI. 1960; (2) Lima No., V.C. et al. Rev. Setor Cien. Agr. UFPr 4: 1. 1982. Potexvirus

Alternanthera mosaic virus (AltMV)

A potexvirus (1), identified as AltMV (2), was found infecting purslane in São José do Rio Preto, SP, resulting in mosaic symptoms (1). This virus was later identified as AltMV (2).

Ref: (1) Tomomitsu, A.T. et al. Virus Rev. \& Res. 11 (supl.): 192. 2006; (2) Alexandre, M.A.V. et al. Rev. Bras. Hort. Ornam. 16: 95, 2010.

\section{Curtovirus}

\section{Brazilian tomato curly top virus (BrCTV)}

Swelling and protuberances on the veins, curved leaves and stunting were described in purslane growing in Campinas, SP, and the causal agent identified as BrCTV. No mechanical transmission was achieved, but the virus was transmitted by the hopper Agallia albidula (1).

Ref.: (1) Costa, A.S. \& Carvalho, A.M.B. Bragantia 19: XIX. 1960.

\section{*Prunus persica (L) Batsch. (Peach) Rosaceae}

Ilarvirus

Prunus dwarf virus (PDV)

Peach plants infected by PDV were detected in commercial orchards and in the germplasm collection of Embrapa/CAPACT in the state of Rio Grande do Sul, through TAS-ELISA (1).

Ref.: (1) Daniels, J. et al. Fitopatol. bras. 19: 329. 1994.

\section{Prunus necrotic ringspot virus (PNRSV)}

Serological assays detected PNRSV and PDV in peach plants showing ringspot on their leaves, in commercial plantations in several regions of the state of Rio Grande do Sul (1).

Ref.: (1) Maciel, S.C. et al.. Fitopatol.bras. 27 (supl.): S209. 2002.

*Prunus persica (L.) Batsch. var. nucipersica (Suckow) C.K. Schneid (Nectarine) Rosaceae

Ilarvirus

Prunus dwarf virus (PDV)

PDV was detected in nectarines in the state of Rio Grande do Sul, during a matrix plant certification program (1).

Ref.: (1) ) Daniels, J. Fitopatol.bras. 24: 195. 1999.

\section{*Prunus salicina Lindl. (Plum) Rosaceae \\ Ilarvirus \\ Prunus necrotic ringspot virus (PNRSV)}

PNRSV was detected in $100 \%$ of asymptomatic plum plants, cvs. Roxa de Itaquera and Satusuma in the state of São Paulo. This virus could be graft transmitted to other plum and peach plants, resulting in slight chlorotic lines forming symmetric figures. The virus could be mechanically transmitted to cucumber, Chenopodium quinoa, Nicotiana glutinosa and cowpea (1). The same virus was detected in the state of Rio Grande do Sul, by immuno assays, during a plum certification program (2).
Ref.: (1) Betti, J.A. et al. Fitopatologia (Lima) 9: 44. 1974;

Daniels, J. Fitopatol.bras. 24: 195. 1999.

\section{*Psycothria mapourioides DC Rubiaceae \\ Tobamovirus \\ Pepper mild mottle virus (PMMoV)}

PMMoV was detected in seedlings of $P$. mapourioides by immunoassays in the Universidade de Brasília, DF, without mention of symptoms and further experiments for viral characterization (1). Ref.: (1) Batista, J.G. et al. Trop.Plt.Pathol. 40 (supl): 354.2. 2015.

\section{*Psidium guajava L. (Guava) Myrtaceae}

Caulimovirus

Caulimovirus unidentified

Caulimovirus-like particles were observed in tissue sections of guava leaves, with yellow mosaic, in samples collected at Monte Aprazível, SP. Symptoms were reproduced in graft-inoculated plants. However no further works to characterize this unidentified virus were carried out (1).

Ref.: (1) Gaspar, J.O. et al. Fitopatol.bras. 18: 289. 1993.

\section{*Psiguria triphylla (Miq.) C. Jeffrey- Cucurbitaceae}

Potyvirus

Papaya ringspot virus W (PRSV-W)

P. triphylla plants with mosaic and foliar deformation were found in an experimental field of passion fruit in Embrapa Cerrados, Planaltina, DF. Further assays revealed that these plants were infected by an isolate of PRSV-W (1).

Ref.: (1) Nakano, D.H. et al. Plant Pathology 57: 398. 2008.

\section{*Psilanthus ebracteolatus Hiern. Rubiaceae}

Dichorhabdovirus

Coffee ringspot virus (CoRSV)

During surveys for CoRSV in a germplasm collection of the Centro de Café, Instituto Agronomico, Campinas, SP, ringspots were observed on the leaves of plants of $P$. ebracteolatus, a rubiaceae close to the genus Coffea. RT-PCR and electron microscopy concluded that the symptoms were due to infection by CoRSV (1).

Ref.: (1) Kitajima, EW et al. Sci.Agric. 68: 503. 2012.

\section{*Psophocarpus tetragonolobus (L.) DC (Winged bean) Fabaceae Comovirus \\ Cowpea severe mosaic virus (CPSMV)}

In a experimental plot of winged bean, for introduction assessment in the Instituto Nacional de Pesquisas da Amazonia, Manaus, AM, some of the plants exhibited conspicous mosaic symptoms. The causal agent was identified as an isolate of CPSMV (1).

Ref.: (1) Kitajima, E.W. et al. Fitopatol.bras. 4: 519. 1979.

\section{*Pueraria sp. (Kudzu) Fabaceae \\ Comovirus \\ Cowpea severe mosaic virus (CPSMV)}

Kudzu plants showing mosaic symptoms were found in IgararéAçú, PA. Biological and serological assays indicated that it was a case of natural infection by CPSMV, sorotype I (1).

Ref.: (1) Nogueira, M.S.R. et al. Virus Rev.\& Res. 7: 156. 2002.

\section{*Pyrus communis L. (Pear), Rosaceae}

Foveavirus

Apple stem pitting virus (ASPV)

ASPV was detected in pear plants, by qRT-PCR in the state Rio Grande do Sul (1).

Ref.: (1) Nickel, O. \& Fajardo, T.V.M. Trop.Plt.Pathol. 39: 28. 2013. 
Unclassified ssDNA virus

Temperate fruit decay associated virus (TFDaV)

Stunted pear plants with weak budding and dried twigs were found in Viçosa, MG. Molecular tools detected still unclassified ssDNA virus (TFDaV), associated to the condition (1). See more detail in Vitis vinifera.

Ref.: (1) Basso, M.F. et al. Virus Research 210: 27, 2015.

$\mathbf{R}$

*Raphanus raphanistrum L. (Wild radish) Brassicaceae

Polerovirus

Beet western yellows virus (BWYV)

Yellowing of lower leaves and marginal chlorosis on wild radish were observed in the state of São Paulo. Causal agent was transmitted in a persistent manner by the aphid Myzus persicae Sulz., and was identified as an isolate of the Beet western yellows virus (BWYV) (1, 2).

Ref.: (1) Costa, A.S. Fitopatologia (Lima) 9: 47. 1974; (2) Costa, A.S. Summa Phytopathol. 6: 28. 1980.

Potyvirus

Turnip mosaic virus (TuMV)

Wild radish with conspicuous mosaic symptoms were found in the state of São Paulo. The causal virus was identified as an isolate of TuMV, aphid transmissible (1).

Ref.: (1) Costa, A.S. Fitopatologia (Lima) 9: 47. 1974.

\section{*Raphanus sp. Brassicasseae}

Nucleorhabdovirus

Nucleorhabdovirus unidentified

An unidentified Raphanus, part of spontaneous vegetation with yellowing was collected in Limeira, SP. Among mechanically inoculated plants, a nucleorhabdovirus was found by electron microscopy in Datura stramonium, considered as an isolate of Brocolis necrotic yellow nucledorhabdovirus- BNYV). No further information is available (1).

Ref.: (1) Kitajima,E.W. \& Costa, A.S. Fitopatol.Bras.4: 55. 1979.

Crinivirus

Tomato chlorosis virus (ToCV)

Unidentified Raphanus with internerval chlorosis in lower leaves were collected in Mauá, PR. RT-PCR assays detected ToCV in this sample (1).

Ref. (1) Boiteux, L.S. et al. Plant Dis. 100: 1027. 2016.

*Rhoe discolor (L'Her) Hance (=Tradescantia spathacea Sw.) (Moses-in-the-cradle) Commelinaceae

Potyvirus

Potyvirus unidentified

Mottled plants of Moses-in-the-cradle were found in a residential garden of Brasília, DF. Electron microscopy detected potyvirus, but no experimental transmission was achieved (1).

Ref.: (1) Rodrigues, M.G.R. \& Kitajima, E.W. Fitopatol. Bras. 6: 533. 1981.

Tobamovirus

Tobamovirus unidentified

Unidentified tobamovirus was detected in Moses-in-the-cradle plant in São Paulo, SP (1).

Ref. (1) Alexandre, M.A.V. et al. Rev.Bras.Hort.Ornam. 16: 95. 2010.

*Rosa spp. (Roseira) Rosaceae

Ilarvirus

Apple mosaic virus (ApMV) (= Rose mosaic virus)

Mosaic symptoms in rose was first described around 1940 in the states of São Paulo and Rio de Janeiro, either in rootstocks or grafted commercial varieties. Observed symptoms were chlorotic bands along the veins and sometimes vein clearing. The condition was transmitted by grafting, but not mechanically. Rose plants of the group Tea, with yellow mosaic, conspicuous chlorotic spots, and elongated and discontinuous yellow streaks in stems were observed in the Instituto Biológico. The disease was considered caused by ApMV $(1,2)$.

Ref.: (1) Kramer, M. Rev.Agric. 15: 301. 1940; (2) Kramer, M. O Biológico 6: 365. 1940.

\section{Prunus necrotic ringspot virus (PNRSV)}

PRNSV was detected in leaves and petals of rose exhibiting mosaic symptoms in samples collected at Atibaia and São Paulo, SP (1). Another isolate of PNRSV was found infecting rose plants in Lagoa Vermelha, RS, being identified by molecular means, and considered belonging to the group PV32 (2).

Ref: (1) Alexandre, M.A.V. et al. Trop. P1. Pathol. 34(supl): S274. 2009; (2) Fajardo, T.V.M. et al. Ciência Rural 45: 2197. 2015

\section{*Rubus spp. (Blackberry) Rosaceae}

Nepovirus

\section{Tomato ringspot virus (ToRSV)}

An isolated of ToRSV was identified infecting blackberry in Vacaria, RS, associated with mosaic symptoms. Transmission and serological assays were used for the identification. (1).

Ref.: (1) Nickel, O. et al. Virus Rev.\& Res. 8: 189. 2003.

*Ruellia chartacea (T. Anderson) Wash. (Peruvian wild petunia) Acanthaceae

Dichorhavirus

Dichorhavirus unidentified

During plant virus survey in Manaus, AM, R. chartacea plants with green spots on senescent leaves were found. Electron microscopy of the lesion tissues revealed cytopathic effects characteristics of those caused by dichorhaviruses (1).

Ref.: (1) Rodrigues, J.C.V. et al. Trop. Plant Pathol. 33: 12. 2008.

\section{*Ruta graveolens L. (Rue) Rutaceae}

Virus, unidentified

During transmission assays of citrus triteza carried out in the Instituto Biológico, São Paulo, SP, in the 1940's, one of the inoculated rue plants showed ringspot symptoms. About the same time, rue cuttings introduced from the Botanical Garden of Buenos Aires, Argentina, presented similar symptoms. Further experiments showed that the causal agent was transmissible to other rue plants, with inactivation temperature of $60^{\circ} \mathrm{C}$, suggesting viral etiology. However characterization of this presumed virus was not concluded (1). Ref.: (1) Silberschmidt, K. O Biológico 12: 219. 1946.

$\mathbf{S}$

\section{*Saccharum officinarum L. (Sugar cane) Poaceae \\ Polerovirus}

Sugarcane yellow leaf virus (ScYLV)

A disease, coined "amarelinho" (yellowing) caused concern on sugar cane culture at the end of 1990's, especially affecting the variety SP 71-6163 in which this condition caused significative losses in the state of São Paulo. Symptoms were variable depending upon the infected variety (1). In highly susceptible varieties as SP 71-6-6163, main vein showed yellowing on the abaxial side; older leaves, 6 th to 7th from the tip, presented main, central vein with reddish color in the adaxial face, followed by color loss and tissue necrosis. Roots and stem had reduced growth resulting in significative yield losses $(7,8)$. Causal agent was identified as a new species of aphid-borne 
polerovirus and named $\operatorname{ScYLV}(1,2,4,5)$. This virus was purified and demonstrated to be isometric ca. $30 \mathrm{~nm}$ in diameter $(3,9)$, being phloem restricted and affecting maize plant metabolism (10). This viral disease was controlled through the use of resistant varieties $(1,6$, 12). ScYLV is now endemic in sugar cane fields in Brazil, but there is no data on possible losses caused by its infection $(8,11)$.

Ref.: (1) Vega, J. et al. Plant Dis. 81: 21. 1997; (2) Maia, I.G. et al. Arch.Virology 145: 1009. 2000; (3) Gonçalves, M.C. \& Vega, J. Fitopat.Bras. 22: 335. 1997; (4) Lopes, J.R.S. et al. Fitopatol.bras. 22: 335. 1997; (5) Gonçalves, M.C. et al. European Journal of Plant Pathology, 108: 401. 2002; (6) Gonçalves, M.C. et al. Virus Rev.\& Res. 7: 26. 2002; (7) Gonçalves, M.C. et al. Fitopatol.bras. 30: 10. 2005; (8) Gonçalves, M. C. Doenças causadas por virus. In: DinardoMiranda, L.L. et al. (Org.). Cana-de-Açúcar. 1 ed. Campinas: Instituto Agronômico de Campinas, 2008, v. 1, p. 450. 2008; (9) Gonçalves, M.C. \& Vega, J. Fitopatol.bras. 32: 50. 2007; (10) Vasconcelos, A.C.M. et al. Functional Plant Sci. \& Biotechnol. 3: 31. 2009; (11) Gonçalves, M.C. Trop.Plant Pathol. 35: 54. 2010; (12) Gonçalves et al. Functional Plant Science \& Biotechnology 6: 108. 2012.

Potyvirus

\section{Sugarcane mosaic virus (SCMV)}

Mosaic symptoms (light green, yellow, white areas alternated with normal green) in sugarcane of viral origin was one of the first viral diseases described in Brazil in the 1920's. The disease, caused by SCMV, possibly was introduced in this period, in the varieties POJ 36, 213 and 218. It is present in all sugar cane growing regions of Brazil (states of São Paulo, Paraná, Goiás, Pernambuco, Alagoas, Rio de Janeiro $(1-5,11,14,16)$. Maize and sorghum are natural hosts for SCMV and serve as well as indicator plants (7). SCMV causes significative losses in the so called noble varieties, but resistance obtained by classical breeding programs solved the problem and presently this virus is not considered important $(8,12,13)$. However, due to the appearance of new severe isolates of SCMV both for sugarcane and maize, replacement of varieties and hybrids had been made quite frequently. SCMV is an aphid-borne potyvirus, and several isolates of SCMV have been found infecting other poaceae species (6, 10). Genome comparison has shown that Brazilian isolates of SCMV are very similar to the Australian isolate Brisbane $(1,16,17)$.

Ref.: (1) Costa Lima, A. Chácaras e Quintais 34: 30. 1926; (2) Bitancourt, A.A. Rev.Agricult. (Piracicaba) 1: 22. 1926; (3) Camargo, T.A.O. Casa Genoud, Campinas. 1926; (4) Vizioli, J. Officinas da Gazeta, Piracicaba. 1926; (5) Caminha, A.F. Brasil Assucareiro 7: 209. 1936; (6) Costa, A.S. et al. Bragantia 10: 301. 1950; (7) Costa, A.S. \& Penteado, M.P. Phytopathology 41: 114. 1951; (8) Matsusoka, S. \& Costa, A.S. Pesq.Agropec.Bras. 9: 89. 1974; (9) Sanguino, A. \& Moraes, V.A. Bol.Tecn.Coopersucar 27: 32. 1984; (10) Pinto, F.J.A. \& Bergamin Fo., A. Fitopatol.bras. 10: 300. 1985; (11) Gonçalves, M. C. Fitopatol.bras. 29: S129. 2004; (12) Gonçalves, M.C. et al. . Fitopatol. bras. 32: 32..2007; (13) Barbosa, A.A.L. et al. Fitopatol.bras. 32:345. 2007; (14) Gonçalves, M.C. Summa Phyopathol. 36 (supl.) CDRom. 2010; (15) Gonçalves, M.C. et al. Trop.Plant Pathol. 35: 54. 2010; (16) Gonçalves, M.C. et al. Pesq.Agropec.Bras. 46: 362. 2011; (17) Gonçalves, M.C. et al. Functional Plant Sci. \& Biotechnol. 6: 108. 2012.

\section{Badnavirus}

Sugar cane bacilliform virus (SCBV) Guadelupe A, IM, MO [BB, Kerala]

Immunosorbent electron microscopy permitted the detection of badnavirus-like, bacilliform particles in asymptomatic sugarcane plants in the state of São Paulo $(1,2)$ and Alagoas (3). A systematic survey made on near 300 samples from a germplasm collection indicated an incidence of $36 \%$ of badnavirus. Molecular analysis based on partial sequencing of these detected badnaviruses indicated presence of six species SCBV Guadelupe A and D, IM, MO, besides SCBV BB (unclassified), one of them possible new species (Kerala) Some of these species seemed to be closely related to banana badnavirus (4)

Ref.: (1) Vega, J. et al. Fitopatol.Bras.16: XXVI.1991.(2) Gonçalves, M. C. Doenças causadas por virus. In: Dinardo-Miranda L.L. et al. (Org.). Cana-de-Açúcar. 1 ed. Campinas: Instituto Agronômico de Campinas, 2008, v. 1, p. 450; (3) Jordão, L.J. et al. Trop.Plt. Pathol. 39: 198. 2013; (4) Silva, J.M. et al. Trop. Plant Path.40, p. 151, 2015.

\section{*Salvia leucantha Cav. (Mexican bush sage) Lamiaceae Cilevirus \\ Cilevirus unidentified}

Green spots on senescent leaves were observed on S. leucantha growing in a residential garden in Piracicaba, SP, associated with infestation by tenuipalpid mite Brevipalpus. Electron microscopy of tissues from these lesions revealed cytopathic effects similar to those caused by cileviruses (1). This condition was reproduced through experiments of transmission with these mites which were identified as B. phoenicis s.l. (2).

Ref.: (1) Kitajima, E.W. et al. Summa Phytopathol. 29: 53. 2003; (2) Kitajima, E.W. \& Ferreira, P.T.O. et al. Fitopatol.bras. 28 (supl.): S250. 2003.

\section{*Salvia splendens Ker Gawl. (Scarlet sage) Lamiaceae \\ Potexvirus}

\section{Althernanthera mosaic virus (AltMV)}

Mosaic symptoms were observed in Scarlet sage collected in São José do Rio Preto, SP, and the causal agent identified as $\operatorname{AltMV}(1,2)$. Ref.: (1) Alexandre, M.A.V. et al. Trop. P1 Pathol. 33 (supl): S231. 2008; (2) Alexandre, M.A.V. et al. Rev.Bras.Hort.Orn. 16: 95-100. 2010

\section{Cucumovirus}

\section{Cucumber mosaic virus (CMV)}

CMV was identified causing stunting, mosaic and leaf deformation in Scarlet sage in the state of São Paulo (1).

Ref. (1) Kudamatsu, M. et al. Summa Phytopathol. 7: 3. 1981.

\section{Begomovirus}

\section{Begomovirus unidentified}

A begomovirus, still unidentified, distinct from other known species were detected by molecular means infecting Scarlet sage in Viçosa, MG. Preliminary assays failed to transmit mechanically this virus (1). Ref.: (1) Krause-Sakate, R. et al. Fitopatol.bras. 23: 318. 1998.

\section{*Schefflera actinophylla (Endl.) Harms (Umbrella tree) Araliaceae Cilevirus \\ Cilevirus unidentified}

Green spots and ringspots were observed in senescent leaves of umbrella tree growing in the campus of Escola Superior de Agricultura Luiz de Queiroz/USP, Piracicaba, SP (1). Cytopathic alterations typical of cileviruses were observed in these lesions by electron microscopy (2). Reproduction of symptoms was achieved by mite transmission experiments (3).

Ref.: (1) Kitajima, E.W.et al. Virus Rev. \& Res. 4: 148. 1999; (2) Kitajima, E.W. et al. Expt. Appl. Acarol. 30: 135. 2003; (3) Ferreira, P.T.O. et al. Fitopatol. bras. 28: S250. 2003.

\section{Badnavirus}

\section{Schefflera ringspot virus (SRV)}

Some umbrella tree used for shading the parking lot of the Guarulhos International Airport (Guarulhos, SP) were found with chlorotic ringspot on their leaves. Electron microscopy detected badnavirus-like particles in the cytoplasm of cells from these lesions. PCR confirmed the presence of a badnavirus, which was considered 
identical to previously described SRV (1). This virus was also detected in umbrella trees collected in the states of Rio de Janeiro, Rio Grande dos Sul and Rio Grande do Norte (2).

Ref.: (1) Brioso, P.S.T. et al. Fitopatol. bras. 28: S247. 2003; (2) Brioso, P.S.T. \& Pozzer, L. . Summa Phytopthol. 36 (supl.) res. 214.2010.

*Sclerolobium melinonii Harms Fabaceae

Tobamovirus

Pepper mild mottle virus (PMMoV)

PMMoV was detected by serological assays in seedlings of $S$. melinonii in a nursery of the Universidade de Brasília, DF (1).

Ref.: (1) Batista,J.G. et al. Trop.Plt.Pathol. 40(supl): 354-2. 2015.

*Scutellaria sp. (Skull caps) Lamiaceae

Potexvirus

Alternanthera mosaic virus (AltMV)

A case of mosaic in skull cap caused by AltMV was reported in São José do Rio Preto, SP $(1,2)$.

Ref.: (1) Alexandre, M.A.V. et al. Trop. Plt Pathol. 33(supl): S231. 2008; (2) Alexandre, M.A.V. et al. Rev.Bras.Hort.Orn. 16: 95-100. 2010 .

*Senecio douglasii DC (Threadleaf ragwort) Asteraceae Orthotospovirus

Chrysanthemum stem necrosis virus (CSNV); Tomato spotted wilt virus (TSWV)

S. douglasii plants were found infected by TSWV, showing vein chlorosis, leaf deformation, tip necrosis and arching in São Roque, SP (1). In another sampling, double infection by TSWV and CSNV of threadleaf ragwort was verified (2).

Ref.: (1) Rivas, E.B. et al. Fitopatol. bras. 20: 346. 1995; (2) Alexandre, M.A.V. et al. Summa Phytopathol. 25: 353.1999

*Senna occidentalis (L.) Link (=Cassia occidentalis L.) (Coffee weed) Fabaceae

Potexvirus

Senna Virus X (SeVX)

Coffee weed plants showing conspicuous mosaic symptoms were collected in Tupã, SP. Preliminary electron microscopy indicated possible infection by a potexvirus. Mechanical transmission assays succeeded in transmitting the unidentified virus to several indicator plants (Chenopodium quinoa, C. amaranticolor e Nicotiana benthamiana). No seed transmission was observed. Serological assays indicated distant relationship with PVX and WCMV (1). The complete genome sequence of this virus was obtained, revealing that it is a new species of potexvirus and designated $\mathrm{SeVX}(2)$.

Ref.: (1) Giampan, J.S. et al. Fitopatol.bras. 29: S211. 2004; (2) Rezende, J.A.M et al. Arch.Virol. 162: 529, 2017.

Potyvirus

Bean common mosaic virus (BCMV)

Isolate of BCMV, which causes chlorotic spot type mosaic in bean, was isolated from field coffee weed plants in the state of São Paulo (1). Ref.: (1) Costa, A.S. et al. Anais I Simp.Bras.Feijão (Campinas). p.305. 1972.

Cowpea aphid-borne mosaic virus (CABMV)

A mosaic in coffee weed, observed in the state of Ceará, was identified as being caused by an isolate of CABMV (1).

Ref.: (1) Lima, J.A.A. \& Gonçalves, M.F.B. Fitopatol.bras. 13: 365. 1988.

Soybean mosaic virus (SMV)

A potyvirus was found infecting coffee weed in Brasília, DF (1), and possibly represents an isolate of SMV as reported in Paraná, PR (2).

Ref.: (1) Santos, O.R. et al. Fitopatol.bras. 16: XXXVIII. 1991; (2) Almeida, A.M.R. et al. Fitopatol.bras. 27: 151. 2002.

\section{*Sesamum indicum L. (Sesamum) Pedaliaceae Orthotospovirus \\ Orthotospovirus unidentified}

An isolate of Orthotospovirus was found infecting field sesamum plants in the state of São Paulo (1).

Ref.: (1) Costa, A.S. \& Forster, R. Bragantia 2: 83. 1942.

Potyvirus

Cowpea aphid-borne mosaic virus (CABMV)

A mosaic in sesamum was attributed to infection by CABMV in the state of Ceará (1).

Ref.: (1) Lima, J.A.A. et al. Fitopatol.bras. 16: 60. 1991.

\section{*Sicana odorifera Naudin (Musk cucumber) Cucurbitaceae \\ Potyvirus \\ Zucchini yellow mosaic virus (ZYMV)}

Musk cucumber plants from an experimental field of Univ. Fed. Minas Gerais, were found with blistering, light mosaic and deformation of leaves. Biological and serological assays concluded that the disease was caused by ZYMV (1).

Ref.: (1) Rocha, F.D.S. et al. Trop.PltPathol. 38 (supl.): 376-1. 2013.

*Sida spp.: Sida acuta Burm., S. carpinifolia (L.) K.Schum.; S. rhombifolia L., S. glaziovii K.Schum., S. cordifolia L. S. micrantha St.Hill., S. urens L., S. Bradei Ulbricht, $S$. spinosa L. Malvaceae Orthotospovirus

Orthotospovirus unidentified

Natural infection of $S$. spinosa by an unidentified toposvirus, resulting in irregular chlorotic spots and leaf deformation was reported in the state of São Paulo (1).

Ref.:(1) Pavan, M.A. et al. Fitopatol.bras. 17: 186. 1992.

Begomovirus

Infectious chlorosis of malvaceae complex (ICMC)

The first description of a golden mosaic in Sida sp. was registered in the 1940's in the state of São Paulo (1). The unidentified causal virus was not mechanically transmissible or by seeds, but it was transmitted by grafting. Experimental transmission using whitefly Bemisia tabaci was achieved $(2,3)$. Later, successful mechanical transmission from S. rhombifolia and S. micrantha to Malva parvifolia was obtained $(4,5)$. These mosaics in Sida spp. and wild malvaceae was considered as being caused by a member of ICMC. These conditions were also observed in the state of Pernambuco (6).

Ref.: (1) Silberschmidt, K. Arq.Inst.Biol. 14: 105. 1943; (2) Orlando, A. \& Silberschmidt, K. Arq.Inst.Biol. 16: 1. 1946; (3) Costa, A.S. Phytopathol.Zeit. 24: 97. 1955; (4) Silberschmidt,K. \& Tommasi, L.R. Ann.Acad.Bras.Cien. 27: 195. 1955; (5) Costa, A.S. \& Carvalho, A.M.B. Phytopathol.Zeit. 37: 259. 1960; (6) Lima, G.S.A. et al. Virus Rev.\& Res. 6: 158.B 2001.

Sida angular mosaic virus (SiAMV)

Sida chlorotic vein virus (SiCVV)

Sida golden mosaic virus Brazil (SiGMV-BZ)

Sida micrantha mosaic virus (SimMV)

Sida mosaic Alagoas virus (SiMAIV)

Sida mottle virus (SiMoV)

Sida mottle Alagoas virus (SiMoAV)

Sida golden yellow mosaic virus (SiGYMV)

Sida yellow mosaic virus Alagoas (SiMV AL)

Sida yellow spot virus (SiYSV) 
With molecular tools it has been possible to detect and identify a large number of begomovirus species not only in Sida spp., but also in other species. Several of these species were accepted by ICTV, while others still are waiting for the official recognition. In most of cases of begomovirus described before the advent of molecular techniques, precise species identification was not feasible. Most of them were considered isolates of AbMBV or ICMC, and for historical records, such identification are registered as such. In the era of molecular technology, several distinct begomoviruses have been identified infecting Sida spp., based on the sequence of their genomes (13). An isolate of SmMV recovered from tomato was shown to be mechanically transmissible to some assay plants, but not to Sida (4). This virus was found infecting tomato in the state of Rio de Janeiro (5). A begomovirus infecting naturally passion flower and causing mosaic and little leaf had 98\% similarity with SiMoV (6). Begomoviruses (SiCSV and SilgYMV) resembling those present in the old world were recovered from Sida acuta, in Viçosa, MG (7). SiMoV was recognized in the state of Paraíba (8). SiMoAV was described infecting Sida spp. in Viçosa, MG and Maragogi, AL (9). SiMAlV was found in the state of Alagoas (10). In the state of Piauí, two possible new species of begomovirus (SiAMV and SiCVV) were found infecting Sida spp. in Esperantina, Piracuruca and Teresina, state of Piauí (11).

Ref.: (1) Fernandes, A.V. et al. Fitopatol.Bras.23: 316; (2) Virus Rev.\& Res. 4(supl.1): 148. 1999; (3) Contin, F.S. et al. Virus Rev.\& Res. 8: 194. 2003; (4) Calegario, R.F. et al. Fitopatol.bras. 29: S150. 2004.(5) Paula, M.B. et al. Fitopatol.Bras.32 (supl): S197. 2007 (6) Moreira, A.G. et al. Fitopatol.bras. 31 (supl): 2006; (7) Xavier, C.A.D. et al. Virus Rev \& Res.20 (supl.): 26. 2015; ; (8) Ferro, M.M.N. et al. Trop. Plant Pathol. 42:39. 2017; (9) Tavares, S.S. et al. Planta Daninha 30: 395. 2012; (10) Wyant, P.S. et al. Virology 427: 151. 2012; (11) Passos, L.S. et al. Arch.Virol. 162: DOI 10.1007/s00705-017-3283-7. 2017.

Sida yellow leaf curl virus (SiYLCV)

SiYLCV was isolated from Sida rhombifolia in Coimbra, MG (1). Ref.: (1) Castillo Urquiza, GP et al. Arch.Virol. 153: 1985. 2008.

Sida common mosaic virus (SiCmMV)

SiCmMV was recovered from Sida micrantha in Coimbra, MG (1) Ref.: (1) Castillo-Urquiza, G.P. et al. Arch.Virol. 153: 1985. 2008.

Sida chlorotic mottle virus (SiCMoV)

A begomovirus isolalted from Sida sp. showing mosaic symptoms was found in the state of Rio Grande do Sul. Genome analysis indicated that it is a new begomovirus species. The closest known begomovirus is Tomato leaf dwarf virus (TLDV), sharing with it $81,5 \%$ of identity (1).

Ref.: (1) Ferro, C.G. et al. Virus Rev.Res. 19 (supl.): 209. 2014.

Begomovirus unidentified

S. rhombifolia and S. spinoa were found infected with still unidentified begomovirus in the state of Alagoas (1). Similar case involving S. cordifolia was reported in the state of São Paulo (2).

Ref.:(1) Assunção, L.P. et al. Planta Daninha 24: 239. 2006. (2) Barbosa, J.C. et al. Summa Phytopathol. 33 (supl): 92. 2007.

\section{*Sidastrum micranthum (St.Hill.) Fryxel Malvaceae \\ Begomovirus \\ Begomovirus unidentified}

An unidentified begomovirus was associated with mosaic symptoms of $S$. micranthum in the state of Alagoas (1).

Ref (1) Assunção, L.P. et al. Planta Daninha 24: 239.2006.

\section{*Sinapsis alba L. (Mustard) Brassicaceae \\ Potyvirus \\ Turnip mosaic virus (TuMV)}

Mustard plants with mosaic symptoms were found in Vassouras and Itaguai, RJ, during a plant virus survey. Further assays indicated that these plants were infected by TuMV (1). Similar case was reported in the state of Paraná (2).

Ref.: (1) Kitajima, E.W. et al. Fitopatol.bras. 9: 607. 1984; (2) Lima, M.L.R.Z.C. et al. Fitopatol. bras. 9:403. 1984.

Caulimovirus

\section{Cauliflower mosaic virus (CaMV)}

CaMV causing mosaic in mustard was reported in the state of Paraná (1).

Ref.: (1) Lima, M.L.R.Z.C. et al. Fitopatol.bras. 9 :403. 1984.

\section{*Sinningia speciosa (Lodd.) Hiern. (Gloxinia) Gesneriaceae}

Orthotospovirus

\section{Chrysanthemum stem necrosis virus (CSNV)}

CSNV was found infecting gloxinia in samples collected at Arujá, SP, exhibiting chlorotic and necrotic ringspot symptoms on their leaves, and flower deformation and discoloration. Identification was made by biological and serological assays (1).

Ref.: (1) Yuki, V.A. et al. Fitopatol.bras. 26: 517. 2001.

\section{Tomato spotted wilt virus (TSWV)}

Infection of gloxinia by TSWV was registered in the state of São Paulo (1).

(1) Alexandre, M.A.V. et al. Rev. Bras. Hortic. Ornam. 11: 49. 2005.

\section{*Solanum aculeatissimum Jacq.(= S. ciliatum LAM. ) (Dutch eggplant) Solanaceae}

Nucleorhabdovirus

Joa yellow blotch virus (JoaYBV)

During surveys of plant viruses in the Amazon basin, dutch eggplant, part of spontaneous vegetation in a citrus orchard, were found showing chlorotic spots on their leaves, near Manaus, AM. Electron microscopy indicated the presence of a nuclerhabdovirus in infected tissues. Graft, but not mechanical transmission was achieved. Molecular assays confirmed the presence of a nucleorhabdovirus with $75 \%$ identity in the sequence of the polymerase gene with Potato yellow dwarf virus (PYDV) and Eggplant mottled dwarf virus (EMDV). This virus was tentatively named JoaYBV (1).

Ref.: (1) Mei, Y. et al. Summa Phytopathol. 42 (supl): res.128. 2016.

Polerovirus

Potato leafroll virus (PLRV)

Natural infection of dutch eggplant by PLRV was reported in the state of São Paulo, and considered as a natural reservoir for this virus, thus linked to its epidemiology for cultivated solanaceous crops $(1,2)$. Ref.: (1) Souza Dias, J.A.C. et al. Fitopatol. bras. 17: 156. 1992; (2) Souza Dias, J.A.C. \& Costa, A.S. Res. VI Enc.Nac.Virol. 176.1992. Potyvirus

Potato virus Y (PVY)

PVY was found infecting dutch eggplant in the state of São Paulo $(1,2)$.

Ref.: (1) Kudamatsu, M. \& Alba, A.P.C. Summa Phytopathol. 5: 15. 1979; (2) Vicente, M. et al. Fitopatol.bras. 4: 73. 1979.

\section{*Solanum aethiopicum Jacq. (Jiló) Solanaceae Orthotospovirus \\ Groundnut ringspot virus (GRSV)}

Jiló plants exhibiting ringspots on leaves and fruits were found in a commercial plantation in Itapólis, SP. Biological and molecular assays indicated that the symptoms were due to infection by GRSV (1).

Ref.: (1) Cruciol, G.C.D. et al. Res. 29 Cong.Bras.Virol. 2018. Tomato chlorotic spot virus (TCSV)

Jiló were found in S. José dos Campos, SP, with symptoms of "vira cabeça". TCSV was considered the causal agent (1). A high incidence 
of such a disease in jiló was reported in commercial plantations in Taiaçú, SP (2).

Ref.: (1) Chaves, A.L.R. et al. Fitopatol.bras. 25: 439. 2000; (2)

Rabelo, L.C. et al. Fitopatol.bras. 27: 105. 2002.

Comovirus

Andean potato mottle virus (APMoV)

Mottling in jilo observed in the state of Rio de Janeiró was found to be caused by an isolate of APMoV (1).

Ref.: (1) Kitajima, E.W. et al. Fitopatol.bras. 9: 607. 1984.

Crinivirus

Tomato chlorosis virus (ToCV)

Symptoms of interveinal chlorosis were observed in jiló cultivated commercially in Venda Nova, ES, Bragança Paulista, SP and Distrito Federal associated with infestation by the whitefly Bemisia tabaci. ToCV was detected in these plants by RT-PCR, and the virus was whitefly transmitted to susceptible tomato lines (1).

Ref.: (1) Fonseca, M.E.N. et al. Plant Dis. 100: 867. 2016.

\section{*Solanum americanum Mill. (Glossy nightshade) Solanaceae Cucumovirus \\ Cucumber mosaic virus (CMV) \\ Potyvirus \\ Potato virus Y (PVY)}

Glossy nightshade plants, growing close to a pepper culture, were found exhibiting mosaic symptoms in Lins, SP. Laboratory analysis indicated that these plants were either infected by PVY alone, or coinfected with CMV. Thus, this species, part of spontaneous vegetation, may serve as natural reservoir of these viruses for pepper and other crops (1)

Ref. (1) Moura, M.F. et al. Summa Phytopathol. 40: 78. 2013

\section{*Solanum atropurpureum Schrank (Purple devil) Solanaceae Potyvirus \\ Potato virus Y (PVY)}

Vein banding, chlorotic punctuations and bending were notice on leaves of purple devil in the campus of the Universidade de São Paulo, São Paulo, SP. Further assays identified the causal agent as an isolate of PVY (1).

Ref.: (1) Chagas, C.M. et al. Phytopathol.Zeit. 90: 147. 1977.

*Solanun commersonii Dan. (Commerson's nightshade) Solanaceae

Begomovirus

Tomato severe rugose virus (ToSRV)

A survey made on the germplasm collection of Embrapa Hortaliças, Brasília, DF, revealed plants of Commerson's nightshade with yellow mosaic and leaf deformation of upper leaves and stunting. Molecular assays associated these symptoms with infection by ToSRV (1).

Ref.: (1) Lima, M.F \& Vieira, D.C. $28^{\circ}$ Cong.Bras.Virol.: Res.400, 2017.

* Solanum jamaicense Mill. (Jamaican nightshade) Solanaceae Crinivirus

Tomato chlorosis virus (ToCV)

$S$. jamaicense plants were found naturally infected by ToCV in Brasília, DF. Identification was made by RT-PCR (1).

Ref.: (1) Boiteux, LS et al. Plant Dis. 102: 1673. 2018.

\section{*Solanum lycocarpum St.Hill. (Wolf apple) Solanaceae}

Potyvirus

Potato virus Y (PVY)

A report of Wolf Apple infected by PVY was made in the state of Minas Gerais, without further details (1).
Ref.: (1) Oliveira, C.D. et al. Fitipatol.Bras. 21: 427.1996.

\section{*Solanum lycopersicum L. (Tomato) Solanaceae \\ Orthotospovirus \\ Chrysanthemum stem necrosis virus (CSNV) \\ Groundnut ringspot virus (GRSV) \\ Tomato chlorotic spot virus (TCSV) \\ Tomato spotted wilt virus (TSWV)}

The syndrome known as "vira-cabeça" in tomato is one of the most destructive viral disease of tomato in Brazil and elsewhere. The name was given by the producers because of the bending of tip of young plants following necrosis. If susceptible varieties are infected in high incidence, the disease may destroy totally the plantation. Early report of this disease were made in 1930's in the state of São Paulo $(1,2)$. Symptomatology may vary depending upon the age of infected plant, variety, environment, isolate/species of the Orthotospovirus. In young plants, development is arrested and the green color becomes pale; young leaves of the tip show necrotic lines and rings and curve downwards. In severe infection, the tip dies. In older plants, symptoms are similar, progressing downwards. Necrotic streaks may appear in the stems. Green fruits may present internal and external necrosis., while mature fruits may show discolored spots or concentric rings. The disease is transmitted in a persistent manner by several species of thrips (3-5). At that time, the causal agent of "vira cabeça" was identified as TSWV, previously described in Australia. Electron microscopy revealed that the viral particles were membrane-bound, $80-100 \mathrm{~nm}$ in diameter, present within cisternae of the endoplasmic reticulum of infected cells $(6,7)$. In the 1990's, thanks to intense researches carried out at the Virus Department, Agricultural University of Wageningen, the Netherlands, with participation of several Brazilians, it became evident that the now Orthotospovirus genus did not comprise a single species (TSWV), but included many distinct species, several of them present in Brazil, infecting naturally many plant species, tomato being one of the most affected culture $(8,9)$. It should mentioned that the type species of Orthotospovirus genus, TSWV, was recovered from tomato at Embrapa Hortaliça em Brasília, DF. In Brazil, the following Orthotospovirus species were detected in tomato: TSWV, GRSV, TCSV and CNSV (12). Defective and interfering forms of TSWV may form after seqüencial mehanical transmission. Surveys have shown presence of GRSV in the states of Pernambuco, TSWV in Distrito Federal, TSWV, TCSV and GRSV in Minas Gerais, TSWV and GRSV in São Paulo, TSWV and TCSV in Paraná, TCSV in Rio Grande do Sul (12). CSNV was found infecting tomato in the state of Minas Gerais (11), Rio de Janeiro (13) and São Paulo (15). GRSV was the only Orthotospovirus found in a survey in commercial tomato fields in the "submédio São Francisco", state of Pernambuco (14). Sequences of viral glycoprotien genes of GRSV and TCSV showed to be almost identical (16). TCSV was found in Belém, PA (17).

Ref.: (1) Azevedo, N. Rodriguesia, 6: 209. 1936; (2) Bitancourt, A.A. O Biológico 2: 98. 1936; (3) Costa, A.S. Bragantia 4: 480. 1944; (4) Costa, A.S. \& Forster, R. Bragantia 1: 491. 1941; (5) Costa, A.S. Bol. Min.Agric. 82p. 1948; (6) Kitajima, E.W. et al. Bragantia 22: XXXV. 1963; (7) Kitajima, E.W. Virology 26: 89. 1965; (8) de Ávila, A.C. et al. J.gen.Virol. 71: 2807.1990; (9) 74: 153. 1993; (10) Resende, R.O. $\mathrm{PhD}$ thesis, Agric. Univ. Wageningen 115p. 1993; (11) Resende, R.O. et al. Fitopatol.bras. 20: 299. 1995; (12) Nagata, T. et al. Fitopat. Bras. 20: 90. 1995; (13) Brioso, P.S.T. et al. Fitopatol.bras. 22: 332. 1997; (14) Lima, M.F. et al. Fitopatol.bras. 22: 340. 1997; (15) Colariccio, A. et al. Summa Phytopathol. 26: 252. 2000; (16) Lovato, F.A. et al. Fitopatol.bras. 29: S101. 2004; (17) Carvalho,T.P. et al. Trop.Plt. Pathol. 40 (supl.): 44-2. 2015.

Tymovirus

Eggplant mosaic virus (EMV) 
Tomato plants showing wrinkling, chlorotic mottling and whitish necrosis on leaves were noticed in Itaquaquecetuba, SP. Causal agent was identified as an isolate of EMV (1), which was purified (2) and analyzed serological and molecularly (3). This virus was experimentally transmitted by the beetle species Epitrix fallada (4), Diabrotica speciosa (5), Epicauta atomaria (6). EMV was also detected in commercial tomato fields in Caxias do Sul, RS (7).

Ref.: (1) Chagas, C.M. et al. Arq.Inst.Biol. 42: 157. 1975; (2) Alba, A.P.C. et al. Summa Phytopathol. 3: 131. 1977; (3) Barradas, M.M. Tese Dr., USP. 161p. 1983; (4) Salas, F.J.S. et al. Res.6 $6^{a}$ Reuní.An.Inst. Biol.. p.34. 1993; (5) Res.Virologica PO-4-02. 1993; (6) Res.5 Enc. Nac.Virol.p.85. 1990 (7) Colariccio, A et al. Summa Phytopathol. 34 (supl): S80. 2008.

\section{Tomato blistering mosaic virus (ToBMV)}

Tomato plants showing severe mosaic and leaf deformation were noticed in a commercial plantation in the state of Santa Catarina. A mechanically transmissible virus was associated with the disease, which was identified as a tymovirus by RT-PCR assays. Sequence analysis of the genome of this virus revealed that it was a new species of tymovirus, being designated as ToBMV $(1,2)$.

ef.: (1) Oliveira, V.C. et al. Virus Genes 46: 190. 2013; (2) Nicolini, C. et al. Arch. Virol. 160: 609. 2014.

\section{Amalgavirus}

\section{Amalgavirus unidentified}

A still unidentified amalgavirus (dsRNA Ca. $3.5 \mathrm{~kb}$, seed transmitted) was detected in surveys made in tomato fields of Campinas, SP and Brazlândia, DF. The virus was detected by molecular tools, but there is no additional information (1).

Ref.: (1) Martins, T.P. et al. Virus Rev.\& Res. 20: 124. 2016

\section{Cucumovirus}

\section{Cucumber mosaic virus (CMV)}

Aphid-borne, CMV infection in tomato has low incidence. Infected plants show leaves of reduced size, stunting and lower yields $(1,2)$.

Ref.: (1) Costa, A.S. Bol.Min.Agric. 82p. 1948; (2) Summa Phytopathol. 9: 37.1983

Ilarvirus

\section{Tobacco streak virus (TSV)}

Natural infection of tomato plants by TSV was first reported in Itatiba, SP, resulting in leaf malformation (1). Seed transmission was verified (2).

Ref.: (1) Costa, A.S. et al. Bragantia 20: CVII. 1961; (2) Cupertino, F.P. Rev.Soc.Bras.Fitopatol. 3: 50. 1969.

Crinivirus

\section{Tomato chlorosis virus (ToCV)}

ToCV was first reported in Brazil, in tomato fields at Sumaré, SP, in the agricultural year of 2006/7 causing interveinal chlorosis (1), and a similar case previously reported in 1999, in Campinas, SP, was possibly caused by ToCV (3). Presence of ToCV was subsequently made in several parts of Brazil: states of Espirito Santo (2), Bahia, Goias, Minas Gerais and Rio de Janeiro (4), Distrito Federal (5). Experimental transmission by the whitefly Trialeurodes vaporariorum was achieved (6). Molecular analysis of the genome sequence indicates that Brazilian isolates of ToCV are closer to those described in Greece (7). Surveys made in Central Brazil, states of Goias and Distrito Federal revealed a frequent co-infection of ToCV and the begomovirus ToRSV in commercial tomato fields (8). ToCV was detected in tomato plants in the state of Pará (9).

Ref. (1) Barbosa, J.C. et al. Plant Dis.92, 1709. 2008; (2) Costa, H.S et al. Trop.Plt.Pathol. 35(supl): S185, 2010; (3) Pavan, M.A. et al. Summa Phytopathol. 25: 36. 1999; (4) Barbosa, J.C. et al. Trop.Plant Pathol. 36: 256. 2011; (5) Nogueira, I. et al. Trop.Plant Pathol. 36 (Supl.) CDRom. 2011; (6) Freitas, D.M.S. et al. Summa Phytopathol. 37 (supl.) CD Rom. 2011; (7) Albuquerque L.C. et al. Trop.Plt.Pathol. 38(supl.):332. 2013; (8) Macedo, M.A. et al. Trop.Plt.Pathol. 39: 449. 2014; (9) Carvalho, T.P. et al. Trop.Plt.Pathol. 40 (supl): res.44-2. 2015.

\section{Polerovirus}

\section{Potato leafroll virus (PLRV)}

Isolates of PLRV may cause distinct symptoms in tomato. Lower leaf yellows: chlorosis and leafroll symptoms in medial to lower leaves. This condition has been commonly seen in tomato grown in the state of São Paulo, being aphid-borne. Causal agent was identified as an isolate of PLRV by biological (1), serological (4) and molecular assays (5). The disease was officially reported in Distrito Federal (2) and in the state of Rio de Janeiro (3).

Ref.: (1) Costa, A.S. et al. Boletim do Campo 183: 8. 1964; (2) Cupertino, F.P. et al. Fitopatologia (Lima) 9: 50. 1974; (3) Robbs, C.F. \& Viegas, E.C. Guia de Controle às pragas e doenças das culturas econômicas do Estado, Sec.Agric.Abast., RJ. 84p. 1978; (4) Souza Dias, J.A.C. \& Costa, A.S. Summa Phytopathol. 20: 50. 1994; (5) Souza Dias, J.A.C. et al. Summa Phytopathol. 27: 104. 2001.

Yellow top: a condition also common in tomato fields, but in low incidence. Symptoms are represented by chlorosis on leaves of the top, followed by small size of leaflets and marginal chlorosis. Lower leaves have normal appearance. Affected plants have lower yields. Transmitted by the aphid Myzus persicae and grafting. It is caused by an isolate of PLRV and experimentally infected other solanaceous plants as Datura stramonium, Physalis floridana, pepper, tobacco and potato and was described in the states of São Paulo (1-3) and Rio de Janeiro (4). Serological relationship was demonstrated between the yellow top agent and PLRVC (5).

Ref.: (1) Costa, A.S. Bol.Min.Agric. 82p. 1948; (2) Costa, A.S. O Biológico 15: 179. 1949; (3) Costa, A.S. \& Carvalho, A.M.B. Arq.Inst. Biol. 28: 71. 1961; (4) Robbs, C.F. \& Viegas, E.C. Guia de Controle às pragas e doenças das Cult.Econo. do Estado, Sec. Agric. Abast., RJ. 84p. 1978; (5) Souza Dias, J.A.C. et al. Summa Phytopathol. 20: 50. 1994.

Potyvirus

\section{Pepper yellow mosaic virus (PepYMV)}

Yellow mosaic and leaf deformation in tomato plants were found to be caused by a potyvirus, identified as a new species by biological and molecular assays, and named PepYMV. It is reported in the states of São Paulo, Distrito Federal (1), and also in Espirito Santo, where it reached epidemical level in the "Zona Serrana" (2).

Ref: (1) Inoue-Nagata, A.K. et al. Virus Rev.\& Res. 8: 186. 2003; (2) Maciel-Zambolin, E. et al. Fitopatol. Bras. 29: 325. 2004.

\section{Potato virus Y (PVY)}

Wrinkled, small and thin leaflets, with thickened veins were observed in tomato plants grown in Piedade, SP. Causal agent was identified an isolate of PVY (1). A severe PVY isolate was described in several tomato growing areas in the state of São Paulo in the 1950's. Infected plants had smaller leaves and were stunted. Leaflets were arched downwards and necrotic streaks, parallel to veins in some medial leaves, and referred to as "risca" (streak). Mosaic may appear in youger leaves (2). Breeding program produced resistant tomato varieties (3).

Ref.: (1) Silberschmidt, K. Arq.Inst.Biol. 23: 125. 1956; (2) Costa, A.S. et al. Bragantia 19: 1111. 1960; (3) Nagai, H. \& Costa, A.S. Bragantia 28: 219. 1969.

\section{Tobacco etch virus (TEV)}

Mottling and wrinkling of leaves were observed in the state of São Paulo, and the symptoms attributed to infection by an isolate of TEV, based on biological and serological assays (1).

Ref.: (1) Pavan, M.A. \& Kurozawa, C. Summa Phytopathol. 21: 49. 1995.

Alphanecrovirus 


\section{Tobacco necrosis virus (TNV)}

TNV was recovered from roots of tomato plants grown in greenhouse in the Instituto Agronomico, Campinas, SP (1).

Ref.: (1) Costa, A.S. \& Carvalho, A.M.B. Bragantia 19: XLCVII. 1960.

Tobamovirus

Tobacco mosaic virus (TMV)

Tomato mosaic virus (ToMV)

Tomato mottle mosaic virus (ToMMV)

Conspicuous mosaic symptoms in tomato cultures is of common occurrence in tomato plantations at the end of developmental cycle. Infected plants become smaller with wrinkling on leaflets, with upward rolling. The condition has been demonstrated to be caused either by TMV or ToMV. Some isolates induce yellow mosaic. Original description was made in the state of São Paulo (1). Resitant varieties have been bred (2). Internal brown spot in fruits may occur (3). First infection of tomato by ToMV was reported in the state of Minas Gerais, and identification was based in biological and serological assays (4). This virus was also registered in the state of São Paulo (5). One way to distinguish TMV from ToMV is to inoculate Nicotiana siylvestris in which TMV becomes systemic, while ToMV only causes localized lesions (5). Inner brown spots in tomato fruits was reported in the state of Paraná (6). Tobamovirus in tomato was recorded in the state of Rio Grande do sul (7). Tomato plants resistant to TMV and ToMV were found showing mosaic and thin leaf symptoms in Uberlândia, MG. Transmission assays and RT-PCR confirmed that the causal virus was an isolate of ToMMV (8), whose genome was entirely sequenced (9). Ref.: (1) Costa, A.S. Bol.Min.Agric. 82p. 1948; (2) Nagai, H. \& Costa, A.S. Rev.Oleric.5. 1965; (3) Costa, A.S. et al. Rev.Oleric. 11: 77. 1971; (4) Fernándes, J.J. et al. Fitopatol.bras. 8: 625. 1983; (5) Caner, J. et al. Fitopatol.bras. 15: 347. 1990; (6) Lima No., V.C. et al. Rev. Set.Cien.Agr.UFPr 9: 34. 1987; (7) Daniels, J. et al. Fitopatol.bras. 19: 296.1994; (8) Marubayashi, J.M. et al. Res. 191. $40^{\circ}$ Cong.Paul. Fitopatol. 2017; (9) Nagai, A et al. Genome Announc. 6: e00427-18, 2018.

Tobravirus

Pepper ringspot virus (PepRSV)

PepRSV was first recorded in tomato grown Itaquaquecetuba, SP, showing chlorotic, interveinal lines, and considered being soil borne via nematodes (1). The virus was also found in Distrito Federal, infecting tomato plants (2).

Ref.: (1) Silberschmidt, K. Phytopathol.Zeit. 46: 209. 1962; (2) Cupertino, F.P. et al. Fitopatol.bras. 16: 251. 1991.

Begomovirus

Recent works on begomoviruses, found in several plant species, particularly in tomato, are strongly biased toward molecular aspects, frequently overlook the pioneer researches, which started in the 1930's, by Silberschmidt's group in the Instituto Biológico, São Paulo, and Costa, in Instituto Agronomico, Campinas, SP. Indeed, first case of whitefly transmission was reported by Silberschmidt and co-workers, while the first begomovirus molecularly characterized, TGMV, was isolated by Costa, who also described BGMV, the most devastating begomovirus in Brazil. The recent introduction into Brazil, of more aggressive type, the biotype $\mathrm{B}$ of Bemisia tabaci, resulted in more frequent problems with begomoviruses, particularly in tomato. And the use of more sensitive molecular tools and involvement of more research groups in Brazil, dealing with begomoviruses resulted in the description of an ever increasing number of new species. Begomoviruses has a great variability resulting from mutation and pseudo-recombination, and it is not rare the finding of two or more distinct species in a single plant. Costa (1) had already noted that, what is now known as begomoviruses, had a high adaptability to new hosts, because of their high genetic variability, quickly evolving and new species are continuously replacing the old ones.

Ref.:(1) Costa, A.S. Fitopatologia 9: 47. 1974.

Begomovirus

Tomato viruses transmitted by the whitefly Bemisia tabaci

In the following lines, reports of begomoviruses anterior to their molecular characterization, are presented.

Infectious chlorosis of malvaceae complex (ICMC)

A diffuse chlorotic spots and interveinal chlorosis on leaves were noticed in an experimental tomato field of the Instituto Biológico, São Paulo, SP. Graft and whitefly transmission experiments resulted in the transmission of the causal agent to tomato, tobacco and Sida rhombifolia, suggesting that it would belong to the group of ICMC $(1,2)$.

Ref.: (1) Flores, E. et al. O Biológico 26: 65. 1960; (2) Costa, A.S. Fitopatologia (Lima) 9: 47. 1974.

\section{"Encarquilhamento"}

Wrinkling and curling of leaves, referred to as "encarquilhamento" by tomato growers, were commonly observed in tomato fields of the states of São Paulo, Minas Gerais and Paraná, sometimes inducing yield losses. The condition was found to be whitefly-transmitted.

\section{"Engrujo"}

"Engrujo" describes a syndrome characterized by intense wrinkling of leaves of affected tomato plants. It is whitefly-borne and occurred in industrial tomato fields in Pesqueira, PE (1).

\section{Euphorbia mosaic virus (EuMV)}

Infection of tomato plants by EuMV is rare, and may result in vein mosaic. It was first described in the state of São Pauo (1). Might correspond to the virus presently identified in Brazil as Euphorbia yellow mosaic virus.

\section{Yellow net}

Leaves showing intense yellowing of veins, in a reticular fashion was noticed in the state of São Paulo. The causal agent was transmitted by the whitefly B. tabaci, and was not characterized (1).

Ref.: (1) Costa, A.S. Fitopatologia (Lima) 9: 47. 1974.

Begomovirus detected by molecular means

The introduction and use of molecular tools in the studies with begomoviruses resulted in an explosion of new species in this genus. PCR techniques, using universal primers, permitted to "fish" without difficulty these viruses, and comparison of genome sequence quickly distinguished new species, according to ICTV criteria. More than 1,000 new species were listed, but a small increase in stringency of criteria do define species, resulted in significant reduction of new species. Unfortunately, the same willingness to describe molecularly these viruses was not followed to complete the biological characterization, and in many cases the basic Koch's postulate has not been completed. It is expected that further works will do so. As above mentioned begomoviruses are highly variable due to several factors (1-3) and such a situation make breeding programs in susceptible cultures, as most of cultivated solanacea and malvacea, extremely complex (4). Ref.: (1) Andrade, E.C. et al. Virus Rev. \& Res. 7: 155. 2002; (2) Virus Rev.\& Res 9: 240. 2004; (3) Albuquerque, L.C. et al. Virus Rev.\& Res. 9: 289. 2004.(4) Inoue-Nagata, A.K. et al. Pesq. Agropec. Bras. 41: 1329. 2006.

Begomovirus of tomato, ICTV recognized species (in 2018) Chino del tomate virus Amazonas

Tomato plants showing interveinal chlorosis and yellow tip were found in Silves, metropolitan Manaus, AM. Molecular studies indicated that the causal begomovirus is distinct from known species. Because the virus with most closer sequence was Chino del tomato virus Mexico, the name Chino del tomate virus Amazonas was proposed (1).

Ref.: (1) Fernandes-Acioli, N.A.N. et al. Trop.Plant Pathol. 36 (Supl.):CDRom. 2011.

Okra mottle virus (OkMoV) 
A unidentified isolate of $\mathrm{OkMoV}$ was found in the state of Tocantins (1).

Ref: (1) Lima No., A.F. et al. Trop.Plt.Pathol 34 (supl): 275. 2009.

Sida micrantha mosaic virus (SimMV)

Abegomovirus was recovered from tomato plants in Bicas, $\mathrm{MG}$, causing chlorosis and foliar deformation It is mechanically transmissible to solanacea and amaranthacea hosts, and was demonstrated to have genome sequence close to SmMV (1). Similar case was registered in the state of Rio de Janeiro (2).

Ref.; (1) Calegario, R.F. et al. Fitopatol.bras. 29: S150. 2004; (2) Paula, M.B. et al. Fitopatol.bras. 32 (supl): 197. 2007.

Sida mottle virus (SiMoV)

SiMoV was detected infecting tomato plants in the state of São Paulo (1).

Ref.: (1) Cotrim, M.A.A. et al. Summa Phytopathol 33:300. 2007.

Sida yellow net virus (SiYNV)

Tomato plants with small chlorotic spots on leaves were collected in tomato fields from two municipalities of the state of Rio de Janeiro. Molecular tools detected a begomovirus, similar to SiYNV, previously described in the state of Minas Gerais, infecting Sida micrantha (1).

Ref.: (1) Acioli, N.A.N.E. et al. Trop.Plt.Pathol. 38 (supl) : 847. 2013.

\section{Tomato chlorotic mottle virus (ToCMoV)}

Yellow mottling on tomato leaves were noticed in samples collected in Seabra, BA. Molecular assays revealed that it was a begomovirus distinct from previously described and named ToCMoV. It was transmitted by $B$. tabaci biotype $\mathrm{B}$ and by DNAs $\mathrm{A}+\mathrm{B}$ (1). This virus was also detected in the state of São Paulo (2)

Ref.: (1) Ribeiro, S.G. et al. Fitopatol.bras. 27: S 211. 2002; (2) Paula, D.F. et al. Virus Rev. \&Res 11(supl): 189. 2006;

\section{Tomato common mosaic virus (ToCmMV)}

ToCmMV was isolated from tomato plants in Coimbra, MG (1) and was also detected in the state of Espirito Santo (2).

Ref. : (1) Castillo-Urquiza, G.P. et al. Arch.Virol. 153: 1985. 2008; (2) Barbosa, J.C. et al. Tropical Plant Pathology 41: 62. 2016.

\section{Tomato golden leaf distortion virus (TGLDV)}

Tomato plants showing intense chlorosis, leaf deformation, mosaic and vein clearing on leaves was collected in Gurupi, TO. A begomovirus was found by molecular means, and its sequence showed that it was a new species named TGLDV. (1).

Ref.: (1) Fernandes-Acioli, N.A.N. et al. Trop.Plant Pathol. 36 (Supl.): CDRom. 2011.

\section{Tomato golden mosaic virus (TGMV)}

This was the first begomovirus recognized in Brazil, being referred to as "chita" by Costa (1). It is of rare occurrence in the state of São Paulo. Its infection is characterized by an intense yellow/golden mosaic. It is mechanically transmissible (1-3). It was purified and the geminated shape of virions visualized (2).

Ref.: (1) Costa, A.S. Fitopatologia (Lima) 9: 47. 1974; (2) Matys, J.C. et al. Summa Phytopathol. 1: 267. 1975; (3) Costa, A.S. et al. Summa Phytopathol. 3: 194. 1977.

\section{Tomato golden vein virus (ToGVV)}

During tomato virus survey in the states of Goias and Distrito Federal, a begomovirus was recovered, causing yellow vein symptoms. Molecular studies showed that it was a new begomovirus species and named ToGVV (1). It was later detected in the state of São Paulo (2). Ref.: (1) Albuquerque, L.C. et al. Fitopatol.bras. 29: S218. 2004; (2) Paula, D.F. et al. Virus Rev. \&Res 11 (supl): 189. 2006.

\section{Tomato interveinal chlorosis virus (ToICV)}

Two begomovirus isolates were recovered from tomato plants in Juazeiro and Bezerros, PE. Their DNA-A were completely sequenced revealing that it represented a new species (1).

Ref.: (1) Albuquerque, LC et al. Arch.Virol. 157: 747. 2012.

\section{Tomato leaf distortion virus (ToLDV)}

Tomato mild mosaic virus (ToMiMV)

ToLDV and ToMiMV were found infecting tomato plants in Paty de Alferes, RJ (1)

Ref.: (1) Castillo-Urquiza, G.P. et al. Arch.Virol. 153: 1985. 2008.

\section{Tomato mottle leaf curl virus (ToMoLCV)}

A begomovirus found in Novo Lino, AL, causing chlorosis and leaf deformation was identified as a new species, based on molecular techniques, and named ToMoLCV, but no biological assays were performed (1). A similar virus was detected in the state of São Paulo (2) and Paraíba (4). Complete sequence of its genome was obtained (3).

Ref.: (1) Assunção, I.P. et al. Summa Phytopathol. 30: 504. 2004. (2) Paula, D.F. et al. Virus Rev.\&.Res. 11(supl): 189. 2006; (3) Albuquerque, LC et al. Arch.Virol. 157: 747. 2012; (4) Ferro, M.M.M. et al. Trop.Plt.Pathol. 42: 39. 2017.

\section{Tomato rugose mosaic virus (ToRMV)}

A whitefly-borne begomovirus causing a rough mosaic in tomato was isolated in the state of Minas Gerais (1). Similar isolates were found in the state of São Paulo (2), Goiás (3) and Paraná (5). The isolate from Goiás was used to study virus-vector relationship (3). Additional molecular works confirmed that ToRMV is a new begomovirus species (4).

Ref.: (1) Fernandes, J.J., et al.. Fitopatol. Bras. 25: 440. 2000; (2) Colariccio, A. et al. Virus Rev.\& Res. 8: 191. 2003; (3) Santos, C.D.G. et al. Fitopatol.bras. 28: 664. 2003. (4) Fernandes, J.J. et al. Plant Pathology 55: 513. 2006. (5) Boiteux, L.S. et al. Trop.Plt.Pathol 34.(supl): S266. 2009.

\section{Tomato severe rugose virus (ToSRV)}

ToSRV is a begomovirus which causes wrinkling of tomato leaves, and was detected in the states of Minas Gerais, Goiás, Pernambuco (1), Santa Catarina (2), São Paulo (3), Paraná and Rio Grande do Sul (4). An isolate of ToSRV isolated in Piracicaba, SP had its genome analyzed, indicating an evolutionary relationship with ToRMV (5).

Ref: (1) Fernandes, N.A.N. Tese Dr. Univ.Brasília, 2010; (2) Lima,A.T.M. et al. Fitopatol.bras. 31(supl):S224. 2006. (3) Paula, D.F. et al. Virus Rev.\&Res. 11(supl): 189. 2006. (4) Boiteux, LS et al. Trop.Plt.Pathol. 34.(supl): S266. 2009; (5) Barbosa, J.C. et al. J. Phytopathology 159: 644. 2011.

\section{Tomato yellow spot virus (ToYSV)}

A begomovirus found infecting tomato in the states of Rio de Janeiro and Espirito Santo, causing yellow spots on leaves was considered a new species and name ToYSV. Molecular studies indicated that it originated as a recombination of a begomovirus from Sida and another unidentified (1). A similar virus was found in Argentina (2).

Ref: (1) Andrade, EC. et al. J.gen.Virol. 87:3687. 2006.(2) Lima No., A.F. et al. Trop.Plt.Pathol. 34 (supl): S275. 2009.

\section{Tomato yellow vein streak virus (ToYVSV)}

Veinal yellow streaks in apical leaflets were observed in tomato plants growing in the region of Campinas, SP. Whitefly (Bemisia tabaci) transmission experiments reproduced the symptoms in assayed tomato plants (1). Molecular studies indicated that it represented a new begomovirus species and named ToYVSV $(2,3)$.

Ref.: (1) Souza Dias, J.A.C. et al. Summa Phytopathol. 22: 57. 1996; (2) Faria, J. et al. Plant Dis. 81: 423. 1997; (3) Ribeiro, S.G. et al. Plant Pathology 55:569. 2006.

Begomovirus found in tomato, still unclassified

Tomato chlorotic leaf curl virus (ToCLCV)

A begomovirus, with divided genome, distinct from those previously described was found infecting tomato, causing a chlorotic leaf curling, in Altamira, PA (1).

Ref.: (1) Quadros, AFF et al. Res.29 Cong.Bras.Virol. 2018.

Tomato chlorotic vein virus (ToCVV) 
ToCVV was found infecting tomato plants in Distrito Federal (1) and state of Ceará (2). No further information available.

Ref.: (1) Ribeiro, S.G. et al. Fitopatol.bras.19: 330. 1994; (2) Acioli,N.A.N.E. et al. Trop.Plt.Pathol. 38 (supl): 847-2. 2013.

Tomato crinkle virus (ToCrV)

Tomato crinkle yellow leaf virus (ToCYLV)

Tomato infectious yellows virus (ToIYV)

These viruses were quoted in (1), without additional information.

Ref.: (1) Fernandes, N.A.N. Tese Dr. Univ.Brasília. 2010.

Tomato leaf curl purple vein virus (ToLCPVV)

Upward curling of leaves and purple veins were observed in tomato plants, in a comercial field in the state of Piauí, during surveys made in 2014/2016. Molecular assays detected a monopartite begomovirus, distinct from previously described. Symptoms were reproduced in tomato infected experimentally by agroinfection (1).

Ref.: (1) Macedo, MA et al. Arch.Virol. 163: 737. 2018.

Tomato mild leaf curl virus (TMLCV)

This unassigned begomovirus was found infecting tomato plants in the state of Rio de Janeiro (1).

Ref. (1) Colariccio,A. et al. Fitopatol.bras. 32 (supl): S306. 2007.

Tomato mosaic Barbados

This begomovirus was found in tomato plants with mosaic symptoms and foliar deformation by PCR assays, in Medicilandia, PA (1).

Ref.: (1) Quadros, A.F.F. et al. 40 Cong.Paul.Fitopat. Res.40. 2017.

Tomato severe mosaic virus (TSMV)

This begomovirus, found infecting tomato in Bicas, MG, causes mosaic and severe yellowing. It is mechanically transmissible to Nicotiana benthamiana and $N$. glutinosa. No mention on its transmission by whitefly. Molecular studies indicated that this was a new begomovirus, and named TSMV (1). Its complete genome sequence was obtained (2).)

Ref.: (1) Calegario, R.F. et al. Virus Rev.\& Res. 8: 193. 2003; (2)

Hallwass, M. et al.Virus Rev\& Res 11 (suppl): 189. 2006.

Tomato yellow mosaic virus (ToYMV)

Quoted in (1) without further information.

Ref.: (1) Albuquerque, L.C. et al. Virus Genes 40: 140. 2010.

Curtovirus

Brazilian tomato curly top virus (BrTCTV)

Curly top disease in tomato is common, but with low incidence, and is not considered economically important. It was first described in the state of São Paulo (1-5), but tomato curly top has been observed in most regions where tomato is cultivated. Two different types of curly top are described though on symptoms standpoint they are undistinguishable. One is transmitted by the hopper Agallia albidula, infecting experimentally several plant species. The other is transmitted by hoppers Agalliana ensigera and A. sticticollis with a more restricted host range. The causal virus has similarities with Beet curly top described in the EUA. Acantospermum hispidum is considered a reservoir for BrTCTV (6). The virus has yet to be molecularly characterized to confirm its identity and taxonomical position.

Ref.: (1) Costa, A.S. \& Forster, R. J.Agron. 2: 295. 1939; (2) Sauer, H.F.G. O Biológico 12: 176. 1946; (3) Kramer, M. O Biológico 13: 44. 1947; (4) Bennett, C.W. \& Costa, A.S. J.Agric.Res. 78: 675. 1940; (5) Costa, A.S. Phytopathology 42: 396. 1952; (6) Costa, A.S. III Semin.Bras.Herbicidas e Ervas Daninhas p.69. 1960.

\section{*Solanum mammosum L (Nipplefruit) Solanaceae Orthotospovirus \\ Orthotospovirus unidentified}

Nipplefruit is commonly used as rootstocks for tomato in the Amazon basin, to overcome soilborne fungal problems, and plants showing bronzing on leaves and concentric rings in fruits were observed in an experimental field of Embrapa Hortaliça, Brasília, DF. A yet to be identified Orthotospovirus was considered the causal agent (1).

Ref.: (1) Madeira, M.C.B. et al. Fitopatol.bras. 14: 163.1989.

Crinivirus

Tomato chlorosis virus (ToCV)

ToCV was found by RT-PCR assay, infecting naturally plants of $S$. mammosum in Brasília, DF (1).

Ref.: (1) Boiteux, L.S. et al. Plant Dis. 102: 1673. 2018.

*Solanum melongena L. (Eggplant) Solanaceae Orthotospovirus

Groundnut ringspot virus (GRSV)

Tomato chlorotic spot virus (TCSV)

Tomato spotted wilt virus (TSWV)

Natural infection of eggplants by two distinct Orthotospoviruses (TSWV and GRSV) was reported in Brasília, DF resulting in leaf distortion and ringspots (1). TSWV was found infecting commercially grown eggplants in Sorocaba, SP (2). An isolate of TCSV was detected infecting eggplant in Limeira, SP (3).

Ref.: (1) Boiteux, L.S. et al. Capsicum and Eggplant Newsletter 12: 75. 1993; (2) Colariccio, A. et al. Fitopatol..Bras. 29: S148. 2004; (3) Gouvêa, M.M.et al. Trop.Plant Pathol. 39 (supl.): CD ROM. 2014.

Comovirus

Andean potato mottle virus (APMoV)

Eggplants grown in the "Vale do Paraíba", state of SãoPaulo, exhibiting mosaic symptoms were found to be infected by a mechanically transmissible isometric virus. Infected cells shows cytopathic effect typical of comoviruses, and was tentatively identified as eggplant mosaic virus $(1,2)$. Following works identified the virus as a strain of $\operatorname{APMoV}(3,4)$. It was also found infecting potato in the state of São Paulo (5).

Ref.: (1) Kitajima, E.W. \& Costa, A.S. Bragantia 27: 5. 1968; (2) Kitajima, E.W. \& Costa, A.S. Phytopathol. Zeit. 79: 289. 1974; (3) de Ávila, A.C. et al. Plant Dis. Reptr. 68: 397. 1984; (4) Brioso, P.S.T. et al. Fitopatol.bras. 18: 526. 1993; (5) Souza Dias, J.A.C. et al. Fitopatol.bras. 19: 322. 1994.

Crinivirus

Tomato chlorosis virus (ToCV)

Eggplants showing interveinal chlorosis was observed in commercial fields in Canguçu,RS, and Formosa, GO. Dot-blot and RT-PCR assays demonstrated that these plants were infected by ToCV, which was whitefly transmitted to susceptible tomato lines (1).

Ref.: (1) Fonseca, M.E.N. et al. Plant Dis. 100: 867. 2016.

Polerovirus

\section{Potato leafroll virus (PLRV)}

An isolate of PLRV, which causes yellow top in tomato, was recovered from chlorotic eggplants in the state of São Paulo, suggesting that they may serve as source of inoculum for PLRV to tomato crops (1).

Ref.: (1) Costa, A.S. \& Carvalho, A.M.B. Coopercotia fev.62,p.34. 1962.

Potyvirus

Potato virus Y (PVY)

Mosaic bearing eggplants were found to be infected by PVY in Distrito Federal (1), in the state of Rio de Janeiro (2) and Inhumas, Go (4). Some resistant lines of the cv. 'Campinas' were obtained (3).

Ref.: (1) Cupertino, F.P. et al. Fitopatologia (Lima) 9: 39. 1974; (2) Kitajima, E.W. et al. Fitopatol.bras. 9: 607. 1984; (3) Brioso, P.S.T. et al. Fitopatol.bras. 12: 144. 1988; (4) Mesquita, L.C. et al. Fitopatol. bras. 15: 127. 1990.

\section{Begomovirus}

Tomato mottle leaf curl virus (ToMoLCV)

Tomato severe rugose virus (ToSRV)

Eggplants collected from commercial fields in Lins and Itapólis, SP, were found to be infected by ToSRV and ToMoLCV, which were 
detected by PCR assays. ToSRV was successfully transmitted by whiteflies to some assay plants $(1,2)$.

Ref.: (1) Gotardi, G.A. et al. Summa Phytopathol. 42 (supl.) res.119. 2016; (2) Moura, M.F. et al. J.Phytopathology 100: 599. 2018.

\section{*Solanum nigrum L. (European nightshade) Solanaceae Cucumovirus \\ Cucumber mosaic virus (CMV)}

Natural infection of $S$. nigrum by CMV, resulting in conspicuous mosaic symptoms, was noticed in plants growing nearby pepper fields in the state of São Paulo. CMV was identified by biological, serological, molecular assays and electron microscopy (1).

Ref.: (1) Moraes, C.A.P. et al. Summa Phytopathol. 30: 127. 2004.

Polerovirus

Potato leafroll virus (PLRV)

PLRV isolate causing yellow top on tomato was recovered from S. nigrum with chlorosis, in the state of São Paulo, and considered as part of the epidemiological cycle of this virus to other solanaceous crops (1).

Ref.: Costa, A.S. \& Carvalho, A.M.B. Coopercotia fev.62,p.34.

Potyvirus

Potato virus $Y$ (PVY)

A case of natural infection of S. nigrum by PVY was reported in the state of Minas Gerais, without additional information (1).

Ref.: (1) Oliveira, C.D. et al. Fitopatol.bras. 21: 427. 1996.

\section{*Solanum palinacanthum Dunal Solanaceae}

Potyvirus

Potato virus Y (PVY)

S. palinacanthum with mosaic symptoms were found in several regions of the state of São Paulo. Laboratory analysis of collected samples revealed that these plants were infected by common and necrotic isolates of PVY (1).

Ref.: (1) Barradas, M.M. et al. Ciencia e Cultura 30 (supl.): 416. 1976.

\section{*Solalnum paniculatum L. Solanaceae \\ Cucumovirus}

Cucumber mosaic virus (CMV)

Mosaic symptoms observed in $S$. paniculatum plants in the state of Pará was attributed do CMV infection (1).

Ref.: (1) Kitajima, E.W. et al. Fitopatol.bras. 5: 407. 1980.

Polerovirus

Potato leafroll virus (PLRV)

Potyvirus

Potato virus Y (PVY)

Presence of PLRV and PVY, infecting S. paniculatum was reported in the state of Minas Gerais (1).

Ref.: (1) Oliveira, C.D. et al. Fitipatol.Bras. 21: 427. 1996.

\section{* Solanum scuticum M. Nee (Jurubeba) Solanaceae Crinivirus \\ Tomato chlorosis virus (ToCV)}

S. scuticum plants were found naturally infected by ToCV in Brasília, DF. Identification was based on RT-PCR assays (1).

Ref.: (1) Boiteux, LS et al. Plant Dis. 102: 1673. 2018.

*Solanum sessiliflorum Dunal (= Solanum topiro Humb. \& Bonpl.) Solanaceae

Orthotospovirus

\section{Groundnut ringspot virus (GRSV)}

Tomato chlorotic spot virus (TCSV)

S. sessiliflorum plants showing mosaic symptoms were found in Campos, RJ. Biological, serological, morphological and molecular tests indicated that these plants were infected by an isolate of GRSV (1). A similar case in Angatuba, SP, was found also to be a case of infection by a Orthotospovirus, but the agent was identified as TCSV (2).

Ref.: (1) Boari, A.J. Virus Rev. \& Res. 4: 154. 1999; (2) Colariccio, A. et al. Summa Phytopathol. 29: 348. 2003.

Crinivirus

Tomato chlorosis virus (ToCV)

During a survey for spontaneous plants being infected by ToCV in Brasília, DF, by RT-PCR assays, S. sessiflorum plants were found as a natural host (1).

Ref.: (1) Boiteux, LS et al. Plant Dis. 102: 1673.2018.

\section{*Solanum sisymbriifolium Lam.( Sticky nightshade) Solanaceae} Comovirus

Andean potato mottle virus (APMoV)

APMoV was identified by biological and serological tests infecting sticky nightshade plants in the state of São Paulo (1).

Ref.: (1) Souza Dias, J.A.C. et al. Fitopatol. Bras. 19: 322. 1994.

\section{* Solanum stramoniifolium Jacq. Solanaceae Crinivirus}

Tomato chlorosis virus (ToCV)

S. stramoniifolium plants were found naturally infected by ToCSV. Identification was made by RT-PCR assays (1).

Ref.: (1) Boiteux, LS et al. Plant Dis. 102: 1673.2018.

\section{* Solanum subinerme Jacq. Solanaceae Crinivirus}

Tomato chlorosis virus (ToCV)

$S$. subinerme was another native plant found naturally infected by ToCV in Brasília, DF. Identification was made by RT-PCR assay (1). Ref.: (1) Boiteux, LS et al. Plant Dis. 102: 1673. 2018.

\section{*Solanum tuberosum L. (Potato) Solanaceae \\ Orthotospovirus \\ Tomato spotted wilt virus (TSWV)}

Infection of potato by Orthotospovirus was originally reported in experimental plots in Instituto Agronomico, Campinas, SP, in 1936/1937. Characteristic symptoms were represented by small chlorotic spots or specks which evolved to necrotic rings causing leaflet death and fall, when they fused. Necrosis may appear in the main vein of the leaves, progressing downwards. Biological assays identified the causal agent as TSWV, the same virus inducing "vira cabeça" in tomato, and spread by thrips (1). TSWV was also reported infecting potato in the state of Rio Grande do $\operatorname{Sul}(2,3)$.

Ref.: (1) Costa, A.S. \& Kiehl, J. J.Agronomia (Piracicaba) 1: 193. 1938; (2) Siqueira, O. et al. Rev.Soc.Bras.Fitopat. 4: 92. 1971; (3) Siqueira, O. et al. Rev.Soc.Bras.Fitopat. 4: 92. 1971.

Comovirus

\section{Andean potato mottle virus (APMoV)}

$\mathrm{APMoV}$ was found infecting potato and inducing mottling symptoms on leaves in the state of São Paulo, being of rare occurrence, without causing serious losses $(1,8)$. This virus was also found infecting cv. "Delta S" in Canoinhas, SC, being detected by serology. The isolate was considered essentially similar to that described infecting eggplant $(3,4)$. Experimentally APMoV was succesfully transmitted by the chrysomelid beetle Diabrotica speciosa (5). APMoV was the first virus to be entirely sequenced in Brazil (6), and served as basis of pionneer works with transgenic plant expressing viral genes (7).

Ref.: (1) Kitajima, E.W. \& Costa, A.S. Bragantia 27: 5. 1968; (2) de Ávila, A.C. et al. Fitopatol.bras. 8: 624. 1983; (3) Plant Dis. Reptr. 68: 997. 1984; (4) Sá, C.M. et al. Fitopatol.bras. 3: 105. 1978; (5) 
Costa, C.L. \& de Avila, A.C. Fitopatol. bras. 9: 401. 1984; (6)Shindo, N. et al. Plant Mol.Biol.. 19: 505. 1992; (7)Vicente, A.C.P. et al. Res. XXI Reun. An. Soc.Bras.Bioq.Biol.Mol, p.113.1992; (8) Souza Dias, J.A.C. et al. Fitopatol.bras. 19: 322. 1994.

Nepovirus

\section{Tobacco ringspot virus (TRSV)}

TRSV was first detected in Brazil in imported cv. 'Anett' tubers in the state of São Paulo (1), and later in cv. 'Olimpia" grown in Canoinhas, SC (2).

Ref.: (1) Silberschmidt, K. O Biológico 31: 176. 1965; (2) Cupertino, F.P. \& Costa, A.S. Bragantia 28: IX. 1969.

Potexvirus

Potato aucuba mosaic virus (PAMV)

PAMV causes a mosaic with bright chlorotic areas on leaves of infected plants. It was first recorded in the state of São Paulo, in some varieties imported from Europe. This virus is mechanically transmissible but has no known vector (1).

Ref.: (1) Costa, A.S. Bol.Min.Agric. 82p. 1948.

\section{Potato virus $X$ (PVX)}

First detection of PVX in Brazil was made in a seed potato field in S.João da Boa Vista, SP. Infection of potato plants by PVX usually is latent, but in some varieties it may cause severe necrosis and death. This virus is mechanically transmissible and has no vector $(1,2)$. PVX has been detected in potato fields wherever this tuber is grown, as in the states of Rio Grande do Sul (3), Minas Gerais $(4,5)$, Pernambuco (5). A study made in 2005/2006 has shown that PVX occurs in low frequency in seven surveyed Brazilian states (6).

Ref.: (1) Silberschmidt, K. et al. Rev.Agricultura (Piracicaba) 21: 23. 1941; (2) Silberschmidt, K. et al. Arq.Inst.Biol. 12: 27. 1941; (3) Siqueira, O. et al. Rev.Soc.Bras.Fitopat. 4: 92. 1971; (3) Figueira, A.R. et al. Fitopatol.bras. 10: 303. 1985; (5) Paz, C.D. et al. Fitopatol. bras. 17: 154. 1992. (6) Ávila, A.C. et al. Hort. Bras. 27: 490. 2009.

Carlavirus

Potato virus M (PVM)

An unidentified isolate of PVM was found infecting potato in the state of Rio Grande do Sul. Identification was based on transmission assays and electron mciroscopy (1).

Ref.: (1) Daniels, J. et al. Fitopatol.bras. 18: 287. 1993.

\section{Potato virus $S$ (PVS)}

Infection of potato by PVS results in latent infection, but it may cause yield losses. In Brazil, its first detection was made by the use of indicator plants and serology in a large number of local or imported seed potatoes, in the state of São Paulo (1). In a comprehensive survey made in 2005/2006 about $6 \%$ of analyzed samples were found infected by PVS (5). PVS has been detected in the states of Rio Grande do Sul (2), Minas Gerais (3), Pernambuco (4), Bahia, Paraná and Santa Catarina (5).

Ref.: (1) Cupertino,F.P. et al. Bragantia 29: XVII. 1970; (2) Siqueira, O. et al. Rev.Soc.Bras.Fitopat. 4: 92. 1971; (3) Figueira, A.R. et al. Fitopatol.bras. 10: 303. 1985; (4) Paz, C.D. et al. Fitopatol. Bras. 17: 154. 1992. (5) de Ávila, A.C. et al. Hort. Bras. 27: 490. 2009.

\section{Alfamovirus}

\section{Alfalfa mosaic virus (AMV)}

AMV-infected potato was first reported in the state of São Paulo, in cv. 'Konsuragis'. Observed symptoms were cream yellow blotches of irregular shape on adult leaves. Presence of AMV in poatoes is rare (1). A similar case was registered in cv. 'Hydra', planted in Poços de Caldas, MG (2).

Ref.: (1) Costa, A.S. Bol.Min.Agric. 82p. 1948; (2) Souza Dias, J.A.C. Summa Phytopathol. 8: 45. 1982.

Ilarvirus

\section{Tobacco streak virus (TSV)}

Natural infection of potato by TSV was registered in Bragança,
SP and Andradas, MG, resulting in necrotic rings or vein necrosis on leaves and necrosis in the stem (1).

Ref.: Costa, A.S. et al. Bragantia 23: I. 1964; Boletim do Campo 190: 68. 1965.

\section{Crinivirus}

\section{Tomato chlorosis virus (ToCV)}

Presence of ToCV infecting potato was first observed in Cristalina, GO, detection being made by RT-PCR (1). Similar findings were made in Brasília, DF (2) and in the regions of "Triângulo Mineiro", state of Minas Gerais and in Southeast state of São Paulo (3).

Ref.: (1) Freitas, D.M.S. et al. Virus Rev.\&Res. 16 (supl.) CDRom. 2011; (2) Lima, M.F. \& Barriolli, C. Trop.Plt.Pathol.39: 208. 2013; (3) Souza Dias, J.A.C. et al. Summa Phytopathol. 39 (supl.): CDRom. 2013.

\section{Polerovirus}

\section{Potato leafroll virus (PLRV)}

PLRV is considered the most important virus for potato crops. Yield losses may be up to $50 \%$ and even $80 \%$ in highly susceptible varieties (12-14). Degenerescence of potato crops caused by PLRV was known in Brazil since the 1930's, as well as that transmission of the causal agent was made by aphids and tubers from infected plants. First official record of PLRV in potato was made by Bitancourt in 1934 (1). Infection by PLRV causes leaf rolling in the running year, and affected plants produce small tubers. This virus is phloem limited and not mechanically transmitted, and dissemination is made by several aphid species, in a persistent-ciculative manner. Control of the disease has been made by the use of virus-free seed potatoes, multiplied in suitable conditions and an efficient system of seed certification. Though a good deal of seed potatoes are imported, Brazil is producing its own seeds based on epidemiological information generated by Costa and co-workers (2-5). Serological works showed that Beet western yellows virus (BWYV) is not associated with potato leaf roll symptoms in Brazil (6). PLRV was found in potato fields of the state of Pernambuco (7). Surveys made in seven Brazilian states in 2005/2006 (8) in the Southern region of the state of Minas Gerais and Alto Parnaíba, in 2010 (9) revealed very low incidence (8) of PLRV, or even its absence (9).

Ref.: (1) Bitancourt, A.A. Arch.Inst.Biol. 5: 185. 1934; (2) Costa, A.S. \& Krug, C.A. Bol. Tecn. IAC 514. 1937; (3) Costa,A.S. \& Carvalho, A.M.B. Coopercotia fev.62. p.34.1962; (4) Cupertino, F.P. \& Costa, A.S. Bragantia 29: 337. 1970; (5) Cupertino, F.P. Tese Dr., ESALQ;USP 59p. 1972; (6) Souza-Dias, J.A.C. et al. Summa Phytopathol. 20: 50. 1994; (7) Assis Fo., F.M. et al. Summa Phytopathol. 22: 57. 1996. (8) de Ávila, A.C. et al. Hort. Bras. 27: 490, 2009. (9) Lima, M.F. et al. ALAP/ENB. ABBA. CD-ROM. N.0119. 2012. (10) Câmara, F.L.A. et al. Fitopatol. bras. 11: 711. 1986. (11) Filgueira, F.A.R. \& Câmara F.L.A. Hort.Bras. 4: 29., 1986. (12) Daniels, J. Summa Phytopathol.: 269. 1995. (13) Figueira, A.R. Summa Phytopathol. 268. 1995. (14) Souza-Dias, J.A.C. Summa Phytopathol. 21: 264. 1995.

Potyvirus

\section{Potato virus $A$ (PVA)}

Mild mosaic and slight wrinkling of potato leaves were observed in the state of São Paulo. These symptoms may disappear in very warm periods. The causal agent was identified as an aphid-borne potyvirus, identified as PVA (1). Yield loss evaluation experiments have shown that with a $25 \%$ infection, losses may reach $37 \%$ (2).

Ref.: (1) Costa, A.S. Bol.Min.Agric. 82p. 1948; (2) Cupertino, F.P. et al. Bragantia 32: I. 1973.

\section{Potato virus Y (PVY)}

Incidence of PVY in Brazilian potato fields was first reported in a seed potato production field in S.João da Boa Vista, SP. The virus was found infecting var. 'Serrana Negra', introduced from Peru, and this 
isolated caused severe necrosis in mechanically or aphid inoculated tobacco plants $(1,2,5)$. When potato plants are co-infected by PVY and PVX, necrosis and death of lower leaves may occur, while leaves at the top show wrinkling and mosaic, and the condition is known as rough mosaic (3). Three strains of PVY are known to infect potatoesPVYO, PVYN e PVYC; the last one is not registered in Brazil yet $(15,16)$. PVY infection often results in yield losses, and it has been found in most of potato growing regions in Brazil as the state of Rio Grande do Sul (5), Minas Gerais (6), Pernambuco (7). The isolate NTN of PVY which causes necrotic rings on the surface of tubers was found in the state of São Paulo (8), as well as in other states [Minas Gerais, Paraná, Bahia, Goias (10), Santa Catarina (11)]. This isolate was recognized based on molecular tools (9). A leaf wrinkling in the cv.'Mona Lisa', in the state of São Paulo was attributed to an isolate of PVYN (12). The presence of the necrotic subgroup PVY ${ }^{\mathrm{NTN}}$ in most of potato producing areas in seven surveyed Brazilian states (Espirito Santo, Goiás, São Paulo, Minas Gerais, Bahia, Paraná, Santa Catarina) confirms how disseminated is this PVY strain in the country (13). Surveys made on potato viruses throughout Brazil in 2005/2006 (13) and 2010 (14) identified PVY as the main virus in potato culture, indicating that it is the main cause of the seed potato degenerescence (13). There is a report of transmission of PVY ${ }^{\mathrm{NTN}}$ by the leafminer fly Lyriomiza huidobrensis in tomato (14).

Ref.: (1) Silberschmidt, K. et al. Rev.Agricultura (Piracicaba) 21: 23. 1941; (2) Nobrega, N.R. \& Silberschmidt, K. Arq.Inst.Biol. 15: 307. 1944; (3) Costa, A.S. Bol.Min.Agric. 82p. 1948; (4) Silberschmidt et al. Amer.Potato J. 31: 213. 1954; (5) Siqueira, O. et al. Rev. Soc. Bras. Fitopat. 4: 92. 1971; (6) Figueira, A.R. et al. Fitopatol.bras. 10: 302. 1985; (7) Paz, C.D. et al. Fitopatol. bras. 17: 154. 1992; (8) Souza Dias, J.A.C. et al. Summa Phytopathol. 25: 36. 1999; (9) Sawazaki, H. et al. Fitopatol.bras. 28: S253. 2003; (10) Souza Dias, J.A.C. et al. Summa Phytopathol. 30: 99. 2004; (11) Souza Dias, JAC et al. Summa Phytopathol. 31(supl): S78. 2006; (12) Souza Dias, JAC et al. Summa Phytopathol. 32 (supl): S95. 2007; (13) de Ávila, A.C. et al. Hort. Bras. 27: 490. 2009; (14) Lima, M.F. et al. ALAP/ENB. ABBA. CD-ROM. N.0119. 2012; (15) Salazar, L.F., 1996. Peru: CIP. 214p; (16) Singh, R.P. et al. Arch. Virol. 153: 1. 2008; (14) Salas, F.J.S. et al. Trop.Plt.Pathol. 38 (supl.): 582-1. 2013.

\section{Tobravirus}

\section{Pepper ringspot virus (PepRSV)}

Natural infection of potato by PepRSV was registered in Guará, SP. This virus induced yellow spots and lines forming concentric rings, sometimes followed by necrosis in adjoining tissues (1).

Ref.: (1) Souza Dias, J.A.C.et al. Summa Phytopathol. 5: 21. 1979.

\section{Tobacco rattle virus (TRV)}

Potato tubers with rings on the surface and also in the pulp were found in Aguaí, SP. Initially it was considered a possible case of infection by Potato moptop virus (PMTV), but subsequent works indicated that the causal agent was TRV (1).

Ref.: (1) Souza Dias, J.A.C. et al. Summa Phytopathol. 29: 95. 2003. Begomovirus

\section{Tomato severe rugose virus (ToSRV)}

\section{Tomato yellow vein streak virus (ToYVSV)}

First mention on the presence of begomovirus in potato fields was made in early 1980's in the state of Rio Grande do Sul. Infection by begomovirus resulted in leaf deformation and yellow mosaic without defined borders (1), and it was considered similar to the deforming mosaic reported in Argentina (2). Transmission by the whitefly Bemisia tabaci was demonstrated (3). Similar condition was observed in the state of São Paulo (4), where a high \% of virus perpetuation through the tubers was observed, contrary to what was known for another begomovirus, AbMBV (5). The virus was partially purified and an antiserum suitable for immunodiagnosis, obtained (6). Potato plants experimentally infected by a begomovirus producing yellow streaks on leaves resulted in deforming mosaic symptoms (7). Molecular analysis of the begomovirus isolated in the State of Rio Grande do Sul revealed high homology with ToYVS $(8,9)$. This isolate was also isolated in Pouso Alegre, MG (10). Potato plants showing deforming mosaic symptoms were found to be infected by an isolate of ToRSV in the state of São Paulo $(11,12)$ and in Central Brazil (13). ToRSV has also high rate of transmission through the tubers of infected plants (14).

Ref.: (1) Daniels, J. \& Castro, L.A. Fitopatol.bras. 9: 398. 1984; (2) Daniels, J. \& Castro, L.A.S. Fitopatol.bras. 10: 306. 1985; (3) Daniels, J. et al. Res.Io Enc.Oleric.Cone Sul, Pelotas, p. 30. 1985; (4) Costa, A.S. et al. Summa Phytopathol. 14: 35. 1988; (5) Costa, A.S. \& Vega, J. Fitopatol.bras. 13: 115. 1988; (6) Daniels, J. \& Castro, L.A.S. Fitopatol. Bras. 17: 214. 1992; (7) Souza Dias, J.A.C. et al. Fitopatol.bras. 22: 17. 1996; (8) Ribeiro, S.G. et al. Fitopatol.bras. 25: 447. 2000; (9) Ribeiro, S.G. et al. Plant Pathology 55: 569. 2006; (10) Figueira, A.R. et al. Summa Phytopathol. 32 (supl.): S58. 2006; (11) Souza Dias, J.A.C. et al. Summa Phytopathol. 33(supl): S43. 2007; (12) Souza Dias, J.A.C. et al. Plant Disease, v.92, n.3, p.487, 2008; (13) Lima, M.F. et al. Virus Rev. \& Res. 16 (sup.1): 225. 2011; (14) Lima, M.F. et al. Acta Hort. (ISHS) p.83, 2012.

\section{Curtovirus}

Brazilian tomato curly top virus (BrCTV)

Cases of potato tubers of cvs. 'Baronesa' and 'Sto. Amor' producing thinned buds, weak plants with short internodes, internerval chlorosis on leaves were observed in the state of Rio Grande do Sul. It is assumed that the causal agent is an isolate of BrCTV because of the symptoms shown by graft-inoculated tobacco and Datura stramonium (1).

Ref.: (1) Siqueira, O. Fitopatologia (Lima) 8: 19. 1973.

\section{*Solanum variabile Mart. Solanaceae}

\section{Polerovirus}

\section{Potato leafroll virus (PLRV)}

Natural infection of $S$. variable growing nearby potato fields by PLRV was noticed in the state of São Paulo, indicating that this plant may serve as natural reservoir for this virus, which infects many cultivated plants, and is one of the most important pathogen for potato crop $(1,2)$.

Ref.: (1) Souza Dias, J.A.C. et al. Fitopatol. Bras. 17: 156. 1992; (2) Souza Dias, J.A.C. \& Costa, A.S. Res. VI Enc.Nac.Virol. 176.1992.

\section{* Solanum velleum Roem \& Schul. Solanaceae Crinivirus}

\section{Tomato chlorosis virus (ToCV)}

In Brasília, DF, $S$. velleum plants were found naturally infected by ToCV, as revealed by RT-PCR assays (1).

Ref.: (1) Boiteux, LS et al. Plant Dis. 102: 1673.. 2018.

\section{*Solanum viarum Dun. (Tropical soda apple) Solanaceae Polerovirus \\ Potato leafroll virus (PLRV)}

PLRV was reported infecting tropical soda apple plants in the state of Minas Gerais, without further information (1).

Ref.: (1) Oliveira, C.D. et al. Fitopatol.bras. 21: 427. 1996.

Potyvirus

\section{Potato virus Y (PVY)}

Isolates of PVY was naturally infecting $S$. viarum plants, causing mosaic symptoms, in the states of São Paulo $(1,2)$ and Minas Gerais (3).

Ref.: (1) Kudamatsu, M. \& Alba, A.P.C. Summa Phytopathol. 5: 15. 1979; (2) Vicente, M. et al. Fitopatol.bras. 4: 73. 1979; (3) Oliveira, 
C.D. et al. Fitipatol.bras. 21: 427. 1996.

*Solanum violifolium Schott. (=Lyciantes asarifolia Kunth \& Bouch.) Solanaceae

This plant has been miswritten as Solanum violaefolium, being violifolium the correct form.

Dichorhavirus

Dichorhavirus unidentified

Chlorotic spots on leaves of $S$. violifolium, associated with infestation by Brevipalpus mites, were observed in the garden of Instituto Agronômico, Campinas, SP. Mites (Brevipalpus obovatus) collected from symptomatic plants reproduced the chlorotic spots on healthy $S$. violifolium. Electron microscopy detected cytopathic effects typical of those caused by dichorhavirus (1).

Ref.: (1) Kitajima, E.W. et al. Fitopatol. bras. 29 (supl.): S65. 2004

Tymovirus

\section{Tomato blistering mosaic virus (ToBMV)}

Conspicuous mosaic symptoms were observed on $S$. violifolium growing in the central park of Piracicaba, SP. The causal agent was easily transmitted to some assay plants; serology and electron microscopy pointed to an unidentified tymovirus as the causal agent, initially considered close the Eggplant mosaic virus- EMV, but possibly a new species (1-3). However, after complete sequencing of its genome, it was concluded that this $S$. violifolium tymovirus is an isolate of ToBMV (4).

Ref.: (1) Kitajima, E.W. et al. Fitopatol. Bras. 25: 441. 2000; (2) Pinto, Z.V. et al. Summa Phytopathol. 29: 79. 2003; (3) Raelo, F.A.C. et al. Summa Phytopathol 38 (supl.) CDRom 2012; (4) Blawid, R. et al. Virus Genes 52: 294. 2016.

Cilevirus

Solanum violifolium ringspot virus (SvRSV)

Chlorotic spots and ringspots were observed on leaves of $S$. violifolium leaves in public parks and residential gardens in Piracicaba, SP, associated with infestation by the tenuipalpid mite Brevipalpus obovatus. Ultrastructural studies on leaf lesions revealed cytopathic effects typical of those caused by cytoplasmic type of Brevipalpustranssmitted viruses (1). This virus, named SvRSV, was experimentally transmitted to a large number of experimental hosts by $B$. obovatus (2). Partial sequence of its genome was obtained after extraction of dsRNA, revealing to be distinct from that of Citrus leprosis $C$ virus (3).

Ref.: (1) Kitajima, E.W. et al. Summa Phytopathol. 26: 133. 2000; (2) Summa Phytopathol. 27: 105. 2001. (3) Ferreira, P.T.O. et al. Summa Phytopathol. 33:264. 2007.

Tobravirus

Pepper ringspot virus (PepRSV)

A case of co-infection of SvRSV and PepRSV in $S$. violifolium in the garden of Clube de Campo, Piracicaba, SP, producing large chlorotic spots on leaves. PepRSV was identified based on biological, serological, morphological and molecular studies (1).

Ref.: (1) Kitajima, E.W. et al. Summa Phytopathol. 28: 106. 2002.

\section{*Sonchus asper ( L) Hill. (Prickly sowthistle) Asteraceae Potyvirus}

Lettuce mosaic virus (LMV)

Samples of prickly sowthistle exhibiting mosaic symptoms were collected in Guarulhos, SP. Infection by LMV was considered responsible for the symptoms based on biological, serological and morphological analysis (1).

Ref.: (1) Chaves, A.L.R. et al. Summa Phytopathol. 29: 61. 2003.

\footnotetext{
*Sonchus oleraceus L. (Sowthistle) Asteraceae

Varicosavirus
}

\section{Lettuce big vein virus (LBVV)}

Sowthistle plants showing vein clearing and chlorotic spots on leaves were found in Guarulhos, SP. Further laboratory studies showed that these plants were co-infected by LBVV and Lettuce mosaic virus (LMV), but not by Mirafiori lettuce virus (MiLV), the other member of the lettuce big vein complex (1).

Ref.: (1) Chaves, A.L.R. et al. Fitopatol.bras. 29 (supl.): S138. 2004. Potyvirus

Lettuce mosaic virus (LMV)

In an experimental field for vegetable crops in São Paulo, SP, mosaic bearing sowthistle plants were found growing nearby. Biological morphological and serological assays demonstrated that these sowthistles were infected by an isolate of LMV (1).

Ref.: (1) Chaves, A.L.R. et al. Summa Phytopathol. 29: 61. 2003.

Potato virus Y (PVY)

Natural infection of sowthistle by PVY, without reference to symptoms, was reported in the state of Minas Gerais (1). Ref.: (1) Oliveira, C.D. et al. Fitipatol.Bras. 21: 427. 1996.

\section{*Sorghum bicolor L. (Sorghum) Poaceae Potyvirus}

Johnson grass mosaic virus (JGMV)

Maize plants collected in Felixlandia e Paracatú, MG, showing mosaic symptoms were found to be infected by an isolate of JGMV, according to RT-PCR assays (1).

Ref.: (1) Souza, I.R.P. et al. . International Journal of Current Research $9: 63415,2017$

\section{Sugar cane mosaic virus (SCMV)}

Mosaic and red stripes on leaves of sorghum were observed in the state of São Paulo. SCMV was identified as the causal agent, which was able to be transmitted by the aphid Rhopalosiphum maidis (Fitch.) (1).

Ref.: (1) Costa, A.S. et al. Fitopatologia (Lima) 8: 7. 1973.

\section{*Spathiphyllum wallisii Regel (Peace lily) Araceae Dichorhavirus \\ Clerodendrum chlorotic spot virus (CICSV)}

Peace lily growing nearby glory bower (Clerodendrum $x$ speciosum) infected by ClCSV, exhibited chlorotic spots on their leaves. Subsequent assays on collected samples demonstrated that these symptoms were due to a natural infection by ClCSV (1).

Ref. (1) Kitajima, E.W. et al. Scientia Agricola 67: 348. 2010.

\section{Coffee ringspot virus (CoRSV)}

A case of natural infection of peace lily plant by CoRSV was observed in a residential garden in Araras, SP (1).

Ref.: (1) Novelli, V.M. et al. Trop Plt Pathol. 34 (supl.): S274. 2009. Cilevirus

\section{Cilevirus unidentified}

Ringspots were noticed on leaves of peace lily plants in a residential garden in Piracicaba, SP, associated with infection by Brevipalpus mites. Cytological studies showed cell alterations typical of those induced by cilevirus infection (1).

Ref.: (1) Kitajima, E.W. et al. Scientia Agricola 67: 348. 2010.

\section{*Spinacia oleracea L. (Spinach) Amaranthaceae \\ Cucumovirus}

\section{Cucumber mosaic virus (CMV)}

A high incidence of severe wilting occurred in a commercial field of spinach was observed in 2015, at the Fazenda Monte Deste, Campinas, SP. Biological, serological, molecular and morphological studies indicated that the causal agent was an isolate of CMV (1).

Ref.: (1) Yuki, V.A. et al. Plant Dis. 101: 2157. 2017.

Potyvirus 


\section{Turnip mosaic virus (TuMV)}

A mosaic in spinach was registered in the state of Paraná and attributed to infection by TuMV (1).

Ref.: (1) Lima, M.L.R.Z.C. et al. Fitopatol.bras. 9: 403. 1984.

\section{*Spylanthes oleracea L. (Toothache plant) Asteraceae Orthotospovirus \\ Tomato chlorotic spot virus (TCSV)}

Ringspot on leaves were observed in commercial fields of toothache plant in Sta.Isabel, PA. Biological, morphological and molecular studies identified the causal agent as an isolate of TCSV (1).

Ref.: (1) Boari, A.J. et al. Trop.Plt.Pathol. 38 (supl): 466-2. 2013.

\section{Orthotospovirus unidentified}

Unidentified Orthotospovirus was found infecting toothache plants in the state of São Paulo (1).

Ref.: (1) Nozaki, D.N. Fitopatol.bras. 31(supl):S170. 2006.

*Stizolobium aterrimum Piper \& TracyI (Black mucuna) Fabaceae Alfamovirus

Alfalfa mosaic virus (AMV)

A yellow mosaic was found in high incidence $(50 \%)$ of black mucuna plants in an experimental field of the Instituto Agronomico, Campinas, SP. Causal agent was identified as an isolate of AMV (1). Ref.: (1) Costa, A.S. et al. Summa Phytopathol. 12: 30. 1986.

\section{*Strelitzia reginae Aiton (Crane flower) Strelitziaceae}

Cucumovirus

\section{Cucumber mosaic virus (CMV)}

RT-PCR assays detected CMV in crane flower samples showing mottling and thickening of the leaf blade in Seropédica and Rio de Janeiro, RJ (1).

Ref.: (1) Almeida, C.M. \& Brioso, P.S.T. Summa Phytopathol. 42 (supl) res.17. 2016.

*Stylosanthes guianensis (Aubl.) Sw. (Brazilian stylo) Fabaceae Brambivirus putative

Stylosanthes mosaic associated virus 1 (StyMAV-1)

Stylosanthes mosaic associated virus 2 (StyMAV-2)

Stylosanthes mosaic associated virus 3 (StyMAV-3)

A survey made in an experimental field of Brazilian stylo maintained by Embrapa Gado de Corte, Campo Grande, MS, plants were found with mosaic symptoms. Molecular analysis detected at least three possible new brambiviruses (StyMAV 1, 2 e 3) (1). StyMAV 1 e 2 was able to infect soybean experimentally. Complete genome sequences of StyMAV 1, 2 e 3 were obtained. It is suggested that StyMAV 1 and 2 would form a new genus "Stylomovirus", while StyMAV-3 would be a Rymovirus (2).

Ref.: (1) Souza, J.M. et al. Res. $28^{\circ}$ CongBras.Virol. \#401. 2017; (2) Res. 29 Cong.Bras.Virol. 2018.

Potyvirus

\section{Potyvirus unidentified}

An unidentifed potyvirus was found associated with mosaic symptoms in Brazilian stylo, in the state of Mato Grosso do Sul (1). Ref.: (1) Silva, M.S. et al. Fitopatol.bras. 31 (supl): S102. 2006.

\section{*Stylosanthes scabra Vogel (Shrubby stylo) Fabaceae}

Potyvirus

Potyvirus unidentified

Plants of shrubby stylo with mosaic, small leaflets, short internod and stunting were found in an experimental field of Embrapa Gado de Corte, Campo Grande, MS. Preliminary studies by electron microscopy identified presence of a potyvirus in tissues from symptomatic leaves (1), which was confirmed by molecular assays (2). NGS revealed three species of potyviruses, still unidentified (3).

Ref.: (1) Kitajima, E.W. et al. Fitopatol.bras. 22: 336. 1997; (2) Silva, K.N. et al. Virus Rev. \& Res.20 (supl.): 211.2015; (3) Souza, J.M. et al. Virus Review \& Res. 21: 132. 2016.

\section{*Syngonium wendlandii Schott. (Arrowhead vine) Araceae} Potyvirus

Dasheen mosaic virus (DsMV)

Mosaic and leaf deformation were noticed on arrowhead vine plants in Brasília, DF. Causal agent was identified as DsMV (1). Ref.: (1) Rodrigues, M.G.R. et al. Fitopatol. bras 9: 291. 1984.

$\mathbf{T}$

*Talinum patense L. Portulacaceae

Ilarvirus

Tobacco streak virus (TSV)

Plants of T. patense showing stunting, leaf wrinkling, necrotic specks and rings on leaves were observed in Arapoti, PR, and attributed to natural infection by TSV (1).

Ref.: (1) Lima No., V.C. et al. Fitopatol.bras. 9: 637. 1984.

*Tapeinochilus ananassae (Hassk.) K. Schum. (Pineapple-ginger) Costaceae

Cytorhabdovirus

Cytorhabdovirus unidentified

Plants of the ornamental pineapple-ginger showing chlorotic stripes and stunting were found in a commercial nursery near Recife, PE. Electron microscopy of leaf tissues demonstrated the presence of cytorhabdovirus, which is still unidentified. Graft and mechanical transmission assays were unsuccessful (1).

Ref.: (1) Coelho, R.S.B. et al. Fitopatol. bras. 27: S 201. 2002.

\section{*Tetragonia expansa Murray (New Zealand spinach) Aizoaceae} Cucumovirus

Cucumber mosaic virus (CMV)

Ringspot symptoms were observed on leaves of New Zealand spinach in a green market of Piracicaba, SP. Further biological, serological, molecular assays and electron microscopy demonstrated that these symptoms were caused by an isolate of CMV subgroup A (1).

Ref.: (1) Kitajima, E.W. et al. Summa Phytopathol. 42: res.127. 2016.

*Thunbergia alata Sims (Black-eyed Susan vine) Acanthaceae Potyvirus

Cowpea aphid-borne mosaic virus (CABMV)

A case of infection of T. alata by CABMV was observed in "Zona da Mata", state of Pernambuco (1).

Ref: (1) Nicolini, C. et al. Trop. Plt Pathol. 34 (supl): S271. 2009.

*Thunbergia erecta (Benth.) T. Anderson (King's mantle) Acanthaceae

Cilevirus

Cilevirus unidentified

Ringspot symptoms were observed on leaves of king's mantle plants in the state of São Paulo, associated with Bevipalpus mites infestation. Electron microscopy detected unidentified cilevirus cytopathology (1).

Ref.: (1) Nogueira et al. Summa Phytopathol. 29: 278. 2003.

*Torenia sp. (Blue wings) Scrophulariaceae

Potexvirus

Alternanthera mosaic virus (AltMV) 
AltMV was detecting causing a latent infection in blue wings plants in São Paulo, SP (1).

Ref.: (1) Duarte, L.M.L. et al. Rev. Bras. Hortic. Ornam. 14: 59. 2008.

Tobamovirus

\section{Tobamovirus unidentified}

Unidentified tobamovirus was detected in blue wings plants in São Paulo, SP (1).

Ref. (1) Alexandre, M.A.V. et al. Rev. Bras. Hortic.Ornam. 16: 95.2010.

\section{*Tradescantia diuretica (Mart.) Handlos (=T. elongata G. Meyer) Commelinaceae \\ Cucumovirus \\ Cucumber mosaic virus (CMV)}

CMV infection was reported in T. diuretica in São Paulo, SP, resulting in symptoms of mosaic and chlorotic rings (1).

Ref.: (1) Duarte, L.M.L. Fitopatol. Bras. 19: 248. 1994.

\section{*Trichosanthes cucumerina L. (Snake gourd) Cucurbitaceae \\ Potyvirus \\ Zucchini yellow mosaic virus (ZYMV)}

Mosaic and leaf deformation were observed in snake gourd plants in Piracicaba, SP, and the causal agent was identified as ZYMV (1). Ref.: (1) Jadão, A.S. et al. Plant Dis. 94: 789. 2010.

\section{*Trifolium sp. (Clover) Fabaceae}

Potexvirus

\section{White clover mosaic virus (WCIMV)}

Trifolium sp. plants showing conspicuous mosaic symptoms were found in a pasture near Guarapuava, PR. Biological, serological assays and electron microscopy on collected samples detected an isolate of WCIMV (1).

Ref.: Mulder, J.G. et al. Fitopatol.bras. 12: 263. 1987.

Alfamovirus

Alfalfa mosaic virus (AMV)

AMV was found co-infecting WClMV in mosaic bearing Trifolium sp. plants found Guarapuava, PR. This virus was detected by transmission assays to test plants, immunotechniques and cytopathological observations (1).

Ref.: (1) Kitajima, E.W. et al. Fitopatol.bras. 12: 284. 1987.

\section{*Triticum aestivum L. (Wheat) Poaceae Cytorhabdovirus \\ Cytorhabdovirus unidentified}

Electron microscopy made in leaf tissues of wheat plants with chlorotic spots found in the Embrapa Cerrados, Planaltina, DF, detected a case of infection by still unidentified cytorhabdovirus (1). Ref.: (1) Kitajima, E.W. et al. Fitopatologia (Lima) 11: 16. 1976.

Tenuivirus, putative

\section{Wheat white spike virus (WWSV)}

Symptoms of white-yellow, large and empty spikes, accompanied by chlorotic streaks on leaves and tillering in wheat plants were first observed in the state of Rio Grande do Sul (1), and later in experimental fields of Embrapa Cerrado, Planaltina, DF (4). Precocious infection may lead to the death of plant (1). It is transmitted by the hopper Sogatella kolophon (3). Electron microscopy associated the disease with a threadlike particles, which form large whorled inclusions in the cytoplasm (2). The available evidences suggest a case of infection by a putative Tenuivirus, tentatively named WWSV.

Ref.: (1) Caetano, V.R. et al. Bragantia 29: XLI. 1970; (2) Kitajima,
E.W. et al. Bragantia 30: 101. 1971; (3) Costa, A.S. et al. Fitopatologia (Lima) 8: 6. 1973; (4) Silva, A.R. et al. Fitopatol.bras. 4: 152. 1979. Benyviridae

\section{Wheat stripe mosaic virus (WhSMV)}

Wheat plants of several varieties, showing symptoms similar to those caused by co-infection by SBWMV and WSSMV were found in Passo Fundo, RS. Molecular assays did not detect any of these viruses. When extracts were analyzed by NGS, a possible member of the family Beniviridae was detected, but possibly distinct from members of the genus Benivirus, considering the divergence in the genome sequence. This virus was associated with the presence of the plasmodiophorid Polymyxa graminis in the roots (1). It is likely that the virus previously identified, based on symptoms and morphology, as Soil-borne wheat mosaic virus $(2,3)$, was indeed WhSMV.

Ref.: (1) Valente, JB et al. Plant Pathology 68: 588. 2019; (2) Caetano, V.R. et al. Indic.Pesq.XIII. IPEAS, DNPEA. Mimeog.12p. 1971; (3) Issa, E. 3 ${ }^{\text {a }}$ Reun.Na.Conj.Pesq.Trigo (mimeog.). 1971.

\section{Bromovirus}

Brome mosaic virus (BMV)

BMV was first described occurring in experimental wheat fields of Embrapa Trigo. Passo Fundo, RS, in lines resistant to SBWMV, showing mild mosaic symptoms. Identification of this virus was based on biological assays [mechanical and beetle (Diabrotica speciosa) transmission], serology and electron microscopy (1).

Ref.: (1) Caetano, V.R. et al. Fitopatol.bras. 15: 363. 1990

Luteovirus

Barley yellows dwarf virus PAV (BYDV)

Yellowing, reduced tillering, stunting associated to low yields in wheat plantations were known in the state of Rio Grande do Sul since 1920 's, with controversial etiology, including viral (1-3). Confirmation that the causal agent of such a condition was BYDV was only made in 1968 (4). In these works a more precise evaluation of losses was made, estimated in $20-30 \%$. It was demonstrated that BYDV is transmitted by several aphid species, being Acyrthosiphum dirhodum the most important. This virus is not mechanically transmitted nor seed-borne, and has a wide host range among poaceae, infecting several other winter cereals. BYDV-resistant or tolerant wheat varieties are known $(4,5)$. It was found that BYDV-susceptible lines are less prone to be infected by rust fungi (6). BYDV was reported infecting wheat in the states of Paraná (7) and Mato Grosso do Sul (8). A review updating these data can be seen in (9).

Ref.: (1) Deslandes, J. Agros 2 (2): 88. 1949; (2) von Perceval, M. Bol. 76 Sec.Agric.RS.1939; (3) Dischinger, R. Supl.Rural Correio do Povo (17/6). 1966; (4) Caetano, V.R. Rev.Soc.Bras.Fitopatol. 2: 53. 1968; (5) Tese Doutorado, ESALQ/USP, 75p. 1972; (6) Caetano,V.R. et al. Rev.Soc.Bras.Fitopatol. 5: 156. 1972; (7) Caetano,V.R. \& Golo, R.S. Fitopatol.Bras.5: 389.1980; (8) Paiva, F.A. \& Goulart, A.P.C. Fitopatol. Bras. 17: 179. 1992; (9) Lau, D. et al. Rev. Plantio Direto (março/abril) 31: 2011.

Bymovirus

\section{Wheat spindle streak mosaic virus (WSSMV)}

Symptoms of diffuse chlorotic bands and/or speckes were observed in wheat planted in several regions of the states of Rio Grande do Sul, Santa Catarina and Paraná. It was demonstrated that the disease was caused by WSSMV by DAS-ELISA (1). Brazilian isolates were close to that reported in Argentina, and was able to infect other cereals (2) Ref.: (1) Schons, J. et al. Trop.Plt.Pathol. 36 (supl.): CDRom 2011; (2) Mar, T.B. et al. Int.J.Agron.2013:1. 2013.

\section{*Triumfetta sp. (Burbark) Malvaceae}

Begomovirus 
Infectious chlorosis of malvaceae complex (ICMC)

Mosaic symptoms observed in Triumfetta sp. plants collected in São Paulo and São Vicente, SP and Brotas, BA, were attributed to infection by a member of ICMC (1).

Ref.: (1) Silberschmidt, K. \& Tommasi, L.R. Ann.Acad.Bras.Cien. 27: 195. 1955

\section{*Triumfetta semitriloba Jacq. (Burbark) Malvaceae}

Begomovirus

Triumfetta yellow mosaic virus (TrYMV)

Infection by a begomovirus was observed in burbark plants in the state of Pernambuco (1). This begomovirus was considered, by molecular tools, as a new species and tentatively named TrYMV (2). Ref. (1) Assunção, L.P. et al. Planta Daninha 24: 239. 2006; (2) Nascimento, L.D. et al. Arch.Virol. 161: 1735. 2016.

\section{*Tropaeolum majus L. (Garden nasturtium) Tropaeolaceae} Orthotospovirus

\section{Orthotospovirus unidentified}

Infection of garden nasturtium plants by an unidentified Orthotospovirus was reported in São Paulo, SP (1).

Ref.: (1) Costa, A.S. \& Forster, R. Bragantia 2: 83. 1942.

Potyvirus

\section{Turnip mosaic virus (TuMV)}

A mosaic in T. majus was first reported in São Paulo, SP. Symptoms include vein clearing, vein banding, chlorotic spots and interveinal rings. It is mechanically transmissible to several assay plants, and was considered similar to a virus described in this ornamental in the USA (1.2). Potyvirus-like particles were found in some experimentally infected hosts (3). The disease was also found in the state of Paraná, being mechanically and aphid-transmitted. Electron microscopy detected potyvirus-like particles and cytopathology typical of potyviruses (4). An isolate found in Brasília, DF was characterized as TuMV based on biological and molecular assays (5). In São Paulo, SP, TuMV also was detected in mosaic bearing garden nasturtium by RT-PCR (6).

Ref.: (1) Silberschmidt, K. Phytopathology 43: 304. 1953; (2) Liu, S.C.Y \& Silberschmidt, K. Phytopathology 51: 413. 1961; (3) Kudamatsu, M. et al. Summa Phytopathol. 4: 3. 1978; (4) Costa Lima No., V.C. \& de Souza, V.B.V. Rev.Setor Cien.Agr. UFPr 3: 66. 1981; (5) Amaral, P.P.R. et al. Virus Rev. \& Res. 6: 151. 2001; (6) Duarte, L.M.L. et al. J.Plant Pathol. 96: 609. 2014.

\section{*Tulipa sp. (Tulip) Liliaceae}

Potyvirus

\section{Potyvirus unidentified}

A still unidentified potyvirus detected by electron microscopy in tulips sold commercially in São Paulo, SP, showing breaking in flowers (1).

(1) Rivas, E.B. et al. Arq. Inst. Biol. 76: 501. 2009.

\section{$\mathbf{U}$}

\section{*Unxia kubitzki H. Robinson Asteraceae \\ Cilevirus}

Solanum violifolium ringspot virus (SvRSV)

Natural infection of $U$. kubitzki, growing nearby SvRSV-infected S. violifolium, by Brevipalpus mite-transmitted SvRSV, resulting in chlorotic lesions on leaves, was reported in Piracicaba, SP (1). Ref. (1) Kitajima, EW et al. Scientia Agricola 67: 348. 2010.

\section{V}

*Vanilla planifolia Jack. ex-Andrews (Vanilla) Orquidaceae Cucumovirus

\section{Cucumber mosaic virus (CMV)}

Tip blight of vanilla plants caused by CMV infection was reported in the state of São Paulo. This virus was mechanically transmitted to vanilla, but not by aphids (1).

Ref.: (1) Costa, A.S. \& Robbs, C.F. Rev.Soc.Bras.Fitopatol. 4: 36. 1971.

\section{*Verbena sp. (Verbena) Verbenaceae}

Tobamovirus

Tobamovirus unidentified

Unidentified tobamovirus was found infecting verbena in São Paulo, SP (1).

Ref. (1) Alexandre, M.A.V. et al. Rev. Bras. Hortic.Ornam. 16: 95. 2010 .

*Vernonia polyantes Less. Asteraceae

Polerovirus

Potato leafroll virus (PLRV)

Potyvirus

Potato virus Y (PVY)

A report has been made of infection of $V$. polyantes by PLRV and PVY, without further details In the state of Minas Gerais (1).

Ref.: (1) Oliveira, C.D. et al. Fitopatol.bras. 21: 427. 1996.

*Vigna luteola (Jacq.) Benth. (Hairy cowpea) Fabaceae Comovirus

Cowpea severe mosaic virus (CPSMV)

Symptoms of bright yellow mosaic and leaf distortion was observed in $V$. luteola, in Praia Grande, SP, and the causal agent identified as an isolate of CPSMV (1).

Ref.: (1) Salas, F.J.S. et al. Res.VII Enc.Nac.Virol. 280. 1996.

Begomovirus

\section{Begomovirus unidentified}

Hairy cowpea plants exhibiting golden mosaic symptoms were found in Peruíbe, SP. Preliminary studies showed that the disease is transmitted by the whitefly Bemisia tabaci, being however distinct from BGMV, and it still remains unidentified (1).

Ref.: (1) Barradas, M.M. \& Chagas, C.M. Arq.Inst.Biol. 49: 85. 1982.

*Vigna mungo (L.) Hepper (Mungo bean) Fabaceae

Comovirus

Cowpea severe mosaic virus (CPSMV)

CPSMV was found infecting $V$. mungo in Brasília, DF, causing mosaic symptoms (1).

Ref.: (1) Lin, M.T. et al. Plant Dis. 66: 67. 1982.

*Vigna radiata (L) R. Wilcz. (Mung bean) Fabaceae

Comovirus

Cowpea severe mosaic virus (CPSMV)

Mung bean plants showing mosaic symptoms were found in Brasília, DF (1) and Itaguaí, RJ (2). The causal agent was a serotype I CPSMV. Ref.: (1) Lin, M.T. et al. Plant Dis. 66: 67. 1982 ; (2) Brioso, P.S.T. et al. Fitopatol.bras. 19: 420. 1994.

Potyvirus

\section{Bean common mosaic virus (BCMV)}

Mosaic and blistering on leaves of mung bean were observed in an experimental field of the Universidade Federal do Ceará, Fortaleza, $\mathrm{CE}$, associated with infection by a potyvirus, which was identified as an isolate of BCMV, based on biological and serological assays (1). Ref.: (1) Lima, J.A.A. et al. Fitopatol.bras. 10: 303. 1985. 
*Vigna unguiculata (L.) Walp. (Cowpea) Fabaceae

Comovirus

Cowpea severe mosaic virus (CPSMV)

CPSMV is an isometric virus, ca. $30 \mathrm{~nm}$ diam., of high concentration in the tissues, transmitted in the nature by chrysomelid beetles, and easily transmitted by mechanical means. It is endemic in most of the cowpea producing areas in Brazil, commonly inducing yield losses. It often causes a blistering mosaic on the leaves of infected cowpea plants. CPSMV was first registered in Brazil in the state of Rio Grande do Sul in 1947, but in samples collected in the Brazilian Northeast (1), and subsequently in several other regions of the states of São Paulo $(2,3)$, Distrito Federal, Ceará, Amazonas, Pernambuco, Piauí, Rio Grande do Norte ,Paraíba and Pará (5-7, 10, 16, 17, 18, 19, 20). Yield losses have been evaluated, which in many cases are considerable (9). Initially considered as an isolate of another comovirus, Cowpea mosaic virus (CPMV), but it is now considered as being distinct species (8). CPSMV was purified and specific antiserum, produced (4). At least four serotypes of CPSMV have been identified in Brazil $(11,12)$. Cerotoma arcuata (Oliv.) (13) and Diabrotica speciosa were identified as transmitting CPSMV (14). Screening for varietal resistance found that there are some highly resistant and even immune varieties, as 'Macaibo' and 'FP 7733-2'(15).

Ref.: (1) Oliveira, M.A.Bol.Tecn.Inst.Agron.Sul (Pelotas) No.1. 1947; (2) Caner, J. et al. O Biológico 35: 13. 1969; (3) Costa, A.S. et al. Rev.Soc.Bras.Fitopatol. 3: 56. 1969; (4) Oliveira, A.R. et al. Rev.Soc. Bras.Fitopatol. 3: 26. 1969; (5) Cupertino, F.P. et al. Fitopatologia (Lima) 9:51. 1974; (6) Lima, J.A.A. \& Nelson, M.R. Plant Dis. Reptr.61: 964. 1977; (7) Kitajima, E.W. et al. Acta Amazonica 9: 633. 1979; (8) Pio Ribeiro, G. \& Paguio, O. Fitopatol.bras. 5: 375. 1980; (9) Gonçalves, M.F.B. \& Lima, J.A.A. Fitopatol. Bras. 7: 547. 1982; (10) Kitajima, E.W. et al. Fitopatol.bras. 7: 537. 1982; (11) Lin, M.T. et al. Phytopathology 71: 435. 1981; (12) 74: 581. 1984; (13) Costa, C.L. et. al. Fitopatol. Bras. 3: 81. 1978; (14) Fitopatol.bras. 6: 523. 1981; (15) Rios, G.P. \& das Neves, B.P. Fitopatol.bras. 7: 175. 1982; (16) Kitajima, E.W. et al. Fitopatol.bras. 9: 607. 1984; (17) Bertacini, P.V.et al. Fitopatol.bras. 19: 271. 1994; (18) Silva, S.P. et al. Fitopatol. bras. 26: 520. 2001;(19) Cezar, M.A. et al. Summa Phytopathol 36(supl)\#097.CDRom.2010; (20) Rodrigues, E.C.S. et al. Trop.Plt. Pathol. 40 (supl.): CD Rom Res. 254.1. 2015.

Cucumovirus

\section{Cucumber mosaic virus (CMV)}

$\mathrm{CMV}$ has been found in cowpea alone, or co-infecting other viruses, in Brazil $(5,6)$. It causes mosaic symptoms, but distinct from those induced by CPSMV, and aphid transmission was demonstrated (1). CMV was detected in seeds of infected plants (1). This virus has been detected in the states of Goiás (1), Pernambuco (5), Ceará (4), Pirauí (3) and Pará (4).

Ref.: (1) Lin, M.T. et al. Fitopatol.Bras.5: 419. 1980; (2) 6: 193. 1981; (3) Res. $1^{\text {a }}$ Reun.Nac. Pesq. Caupi, p.101. 1982; (4) Silveira, L.F.S. \& Lima, J.A.A. Fitopatol. Bras.11. 369. 1986; (5) Assis Fo., F.M. \& Paz, C.D. Fitopatol.bras. 18: 287. 1993; (6) Paz, C.D. Et al. Fitopatol. bras. 20: 325. 1995; (7) Rodrigues, E.C.S. et al. Trop. Plant Pathol. 40 (supl.): CD Rom Res. 254.1. 2015.

Potyvirus

\section{Cowpea aphid-borne mosaic virus (CABMV)}

CABMV produces a mosaic pattern distinct from that caused by CPSMV. It is also quite frequent in cowpea fields in Brazilian territory, especially Northeast. First record of CABMV was made in the state of Pernambuco (1). It is likely that some other potyviruses reported on cowpea as green vein banding, rugose mosaic and severe mottling in samples collected in the Northeaster Brazil were isolates of CABMV $2-8,11)$. Some isolates of potyviruses found in cowpea were also referred to as Blackeye cowpea mosaic potyvirus (BCPMV) (2-8), which is now considered as an isolate of CABMV based on molecular criteria. There are reports of the presence of CABMV in cowpea seeds (9). CABMV was reported in the state of Rio de Janeiro (10), Paraíba (13) and Pará (14). Potyvirus infecting cowpea has been reported in RJ (10). Varietal resistance for CABMV was reported in works conducted at Embrapa Meio Norte, in the state of Piauí (12).

Ref.: (1) Paguio, O. Fitopatol.bras. 3: 125. 1978; (2) Lin, M.T. et al. Fitopatol.bras. 4: 120. 1979; (3) Lima, J.A.A. \& Lima, M.G. Fitopatol. bras. 5: 415. 1980; (4) Lin, M.T. et al. Fitopatol.bras. 5: 419. 1980; (5) Santos, A.A. et al. Fitopatol.bras. 5: 457. 1980; (6) Lima, J.A.A. et al. Fitopatol.bras. 6: 205. 1981; (7) Lin,M.T. et al. Fitopatol.bras. 6: 73. 1981; (8) 6: 193. 1981; (9) Silveira, L.F.S. \& Lima, J.A.A. Fitopatol.bras. 11: 369. 1986; (10) Kitajima, E.W. et al. Fitopatol.bras. 9: 607. 1984; (11) Santos, A.A. et al. Fitopatol.bras. 9: 567. 1984; (12) Nogueira, M.S.R. et al. Summa Phytopathol. 32(supl):S 50. 2006.13) Cezar, M.A. et al. Summa Phytopathol 36 (supl.): \#097.CDRom.2010; (14) Rodrigues, E.C.S. et al. Trop. Plt.Pathol. 40 (supl.): CD Rom Res. 254.1. 2015.

\section{Begomovirus}

\section{Cowpea golden mosaic virus (CPGMV)}

This begomovirus was first found nearby São Luis, MA, being transmitted by the whitefly Bemisia tabaci, and is commonly present in cowpea field in the Brazilian Northeast. (1,3). CPGMV- resistant genotypes have been identified (4). It seems to be close to a virus causing golden mosaic in Macroptilium lathyroides in $\mathrm{CE}(5,6)$. CPGMV was detected in the state of Paraíba (7).

Ref.: (1) Kitajima, E.W. et al. Fitopatol.bras. 7: 537. 1982; (2) Santos, A.A. \& Freire Fo., F.A. Fitopatol.bras. 9: 406; (3) 407. 1984; (4) 11: 288. 1986; (5) Lima, J.A.A. et al. Virus Rev.\& Res. 3 (supl.1): 143. 1998; (6) Fitopatol.Bras.23: 319. 1998.(7) Freitas, A.S. et al. Trop.Plt. Pathol. 35 (supl.): S214. 2010.

*Vigna unguiculata (L.) Walp. Subsp. sesquipedalis (L.) Verdc. (Yardlong bean, Asparagus bean) Fabaceae

Comovirus

Cowpea severe mosaic virus (CPSMV)

Blistering mosaic as that seen in cowpea, is quite common in yardlong bean cultivated in Brazil. First report of CPSMV infection in this plant, has been made in Brasília, DF (1).

Ref.: (1) Lin, M.T. \& Anjos, J.R.N. Plant Dis. 66: 67. 1982.

Potyvirus

\section{Cowpea aphid-borne mosaic virus (CABMV)}

Vein banding mosaic in yardlong bean was observed in the state of Pará. It was associated with a potyvirus, tentatively identified as CABMV (1). Recent redetection of this virus in Embrapa Amazonia Oriental, confirmed its identity as CABMV (2).

Ref.: (1) Kitajima, E.W. et al. Fitopatol.bras. 5: 407. 1980; (2) Rodrigues, E.C.S. et al. Trop.Plt.Pathol. 39 (supl.): CD Rom. 2014.

\section{*Vigna vexillata (L) A. Rich. (Wild cowpea) Fabaceae Comovirus Cowpea severe mosaic virus (CPSMV)}

Natural infection of wild cowpea by CPSMV was reported in the state of Pernambuco, based on biological and serological assays (1). Ref.: (1) Gueiros Jr., F. et al. Res.III Cong.Inic.Cient.UFRPe p.55. 1993.

\section{*Viola odorata L. (Violet) Violaceae Potyvirus Potato virus Y (PVY)}

An isolate of PVY was found naturally infecting ornamental violet in the state of São Paulo (1).

Ref.: (1) Colariccio, A. et al. Summa Phytopathol. 34 (supl): S47. 
2008.

*Vitis vinifera L., Vitis labrusca L., Vitis spp. (Grapevine) Vitaceae Nepovirus

\section{Grapevine fanleaf virus (GFLV)}

Grapevine rootstoch 106-8 ("Traviú") presented symptoms of mosaic, irregular and sparse chlorotic spots, chlorotic bands in zigzag, and occasionally smaller and deformed leaves. Such condition was first noticed in the state of São Paulo, being graft transmitted (1). The disease, also known as "fanleaf" is caused by GFLV, a Xiphinema nematode-borne, nepovirus. The virus was seen by electron microscopy (3). In the state of Rio Grande do Sul, some morphological changes in stems, as short internodes, double knots, flattening and bud proliferation were observed in cvs. "Pirovano 54" and "Pirovano 149", and considered to be caused by the fanleaf, or "Court Noué" agent (4). Kuniyuki et al. (5) demonstrated the identity of "Mosaico do Traviú" and fanleaf. Another isolate of GFLV is considered responsible for a symptom variation known as grapevine yellow vein mosaic, characterized by intense yellow spots mainly on primary veins. It was observed initially in the cv. 'Niagara rosada' in Jundiaí, Louveira and Valinhos, SP, and in the cv. 'Pirovano' in São Roque, SP (7). This GFLV isolate is mechanically transmissible to some assay plants $(2,7)$. Some isolates were characterized serological and molecularly $(6,9)$. GFLV was also detected in Zona da Mata, MG and in the São Francisco Valley, PE (9).

Ref.: (1) Kuniyuki, H. Rev.Soc.Bras.Fitopatol. 5: 123. 1972; (2) Kuniyuki, H. Rev.Soc.Bras.Fitopatol. 5: 121. 1972; (3) Vega, J. \& Kuniyuki, H. Summa Phytopathol. 4: 15. 1978; (4) Kuhn, G.B. \& Siqueira, O. Fitopatologia (Lima) 9: 56. 1974; (5) Kuniyuki, H. et al. Fitopatol.bras. 19: 224.1994; (6) Fajardo et al. Fitopatol.bras 25: 505. 2000; (7) Fajardo, T.V.M. et al. In Fajardo, T.V.M. ed. Uva para processamento-Fitossanidade. Embrapa Inf. Tecnol. p.45. 2003; (8) Radaelli, P. et al. Trop. Plant Path. 34: 297. 2009; (9) Catarino, A.D.M. et al. Ciência Rural 45: 379, 2015.

Foveavirus

\section{Grapevine rupestris stem pitting-associated virus (GRSPaV)}

Grapevines infected by GRSPaV has reduced growth, weaker stems, younger leaves with reddening or yellowing, thick bark (the reason of the popular name for the disease in Brazil- "cascudo"). In advanced stages, stem pitting may occur. Thes symptoms are similar to those referred as "legno riccio" and "rugose wood". It was first recorded in the states of São Paulo in cvs. as 'Itália' and 'Rupestris du Lot' (1), and also in rootstock varieties, with less intense symptoms, as 'Golia' and 'Kober 5BB' (3). Similar condition are registered in the states of Paraná (2) and Rio Grande do Sul (4). The virus can be detected by graft assay on 'Rupestris du Lot' (3). An isolate, severe in 'Kober 5BB', but very mild in 'Rupestris du Lot' was found in the state of São Paulo (5). The causal agent of these diseases were attributed to GRSPaV, and confirmation was made by molecular methods (6-9). The virus was detected in the states of Pernambuco, Paraíba, and Bahia (10) in the Zona da Mata, MG and São Francisco Valley, PE (11) and Mato Grosso do Sul (12).

Ref.: (1) Kuniyuki, H. Rev.Soc.Bras.Fitopatol. 5:137. 1972; (2) Kuniyuki, H. Fitopatol.bras. 6: 300. 1981; (3) Kuniyuki, H. \& Muller, G. Summa Phytopath. 13: 26. 1987; (4) Kuhn, G.B. Fitopatol. Bras. 17: 194. 1992; (5) Kuniyuki, H. \& Costa, A.S. Summa Phytopathol. 18: 13. 1992; (6) Espinha, L.M. et al. Fitopatol.bras. 26 (supl.): 533. 2001; (7) Espinha, L.M. et al. Fitopatol. bras. 28: 206. 2003; (8) Fajardo, T.V.M. et al. Fitopatol. bras. 29: 209. 2004; (9) Radaelli, P. et al. Trop. Plant Pathol. 34: 297. 2009; (10) Catarino,A.D.M. et al. Trop. Plt.Pathol. 38 (supl): CDRom 371-1.2013; (11) Catarino, A.D.M. et al. Ciência Rural 45: 379, 2015; (12) Stangarlin, O.S. et al. Summa Phytopathol. 42 (supl): res.06. 2016.
Trichovirus

Grapevine Pinot gris virus (GPGV)

GPGV was found during a survey made in the grapevine germplasm collection of Embrapa Uva e Vinho, Bento Gonçalves, RS By RT-PCR indexing. About $20 \%$ of the tested samples were infected (1).

Ref.: (1) Fajardo, TVM et al. Australasian Plt.Dis.Notes 12: 45. 2017. Vitivirus

\section{Grapevine virus $A$ (GVA)}

Stem pitting of cv. 'Kober' is part of a complex of at least four viruses causing alterations in the grapevine wood. Causal agent is identified as GVA, an elongated and ssRNA virus, naturally spread by mealybugs. It is mechanically transmitted, with difficulty, to some assay plants. In Brazil, GVA was detected in grapevines grown in the states of Rio Grande do Sul, São Paulo and Pernambuco. Stem pitting caused by GVA characterizes by grooving in the wood, below the bark of susceptible varieties as 'Kober 5BB', used as indicator plant. Infection by GVA may cause vigor reduction, delay in budding, and in susceptible combinations, decline and yield losses and early death (1-5), GVA was detected in PE and PB (6) and also found in the Zona da Mata, MG and São Francisco Valle, PE (7).

Ref.: (1) Kuhn, G.B. et al. Fitopatol.bras. 25(supl.): 442. 2000; (2) Kuniyuki, H. et al. Summa Phytopathol. 27: 116-117. 2001; (3) Fajardo, T.V.M. et al. Fitopatol.bras. 28: 521-527. 2003; (4) Kuniyuki, H. et al. Fitopatol.bras. 28:323. 2003; (5) Moreira, A.E. et al. Fitopatol. bras. 29: 205. 2004; (6) Catarino,A.D.M. et al. Trop.Plt.Pathol. 38 (supl) CDRom 371-1.2013; (7) Catarino, A.D.M. et al. Ciência Rural 45: 379. 2015.

\section{Grapevine virus $B(\mathrm{GVB})$}

GVB was found in grapevine cultivars 'Niagara Branca' and 'Niagara Rosada' in the state of São Paulo (2), in cv. 'Isabel' in the state of Rio Grande do Sul $(3,7)$ and Santa Catarina (4). In infected plants there is a delay in the spring budding and a lesser vegetative development; during flowering, symptoms as mild interveinal chlorosis, swelling in the internodes of the stem of the year with longitudinal fissures, and presence of corticous tissues become evident (1). This condition is also known as "corky bark". Diagnosis is based on the detection of GVB grafting on the indicator 'LN33', which when infected, presents symptoms of severe fissures in the stem bark (5). There are GVB isolates which do not cause symptoms in American grapevines $(6,11)$. GVB was identified by the morphology of its virion (elongated, ca. 800 $\mathrm{nm}$ long), size of capsidal protein $(23 \mathrm{kDa})$ and indexation $(9,10,12$, 14). It was found in "submédio São Francisco" and "Zona da Mata", state of Pernambuco $(8,15)$, Mato Grosso do Sul (16). In the state of São Paulo, transmission of GVB by the mealybug Pseudococcus longispinus was achieved (13).

Ref.: (1) Kuniyuki, H. Fitopatologia (Lima) 8: 10. 1973; (2) Kuniyuki, H. Fitopatol.bras. 6: 153. 1975; (3) Kuhn, G.B. Fitopatol.bras. 6: 536.1981 (4) Kuniyuki, H. Fitopatol.bras. 6: 300. 1981; (5) Kuniyuki, H. \& Costa, A.S. Fitopatol.bras. 7: 71. 1982; (6) Kuniyuki, H. \& Costa, A.S. Summa Phytopathol.17: 38.1991; (7) Kuhn, G.B. Fitopatol.bras. 17: 399. 1992; (8) Kuhn, G.B. et al. Fitopatol.bras. 25: 442. 2000; (9) Kuniyuki, H. et al. Fitopatol.bras. 25: 443. 2000; (10) Nickel, O. et al. Fitopatol. bras. 27: 279. 2002; (11) Moreira, A.E. Fitopatol. bras. 29: 75. 2004; (12) Moreira, A.E. et al. Fitopatol. bras. 30:538. 2005; (13) Kuniyuki, H. et al. Summa Phytopathol. 32:151. 2006; (14) Radaelli, P. et al. Pesq. Agropec. Bras. 43: 1405. 2008; (15) Pio Ribeiro, G. et al. Trop Plt Pathol. 34(supl.): S276. 2009; (14) Catarino,A.D.M. et al. Trop.Plt.Pathol. 38 (supl.): CDRom 371-1.2013; (15) Catarino, A.D.M. et al. Ciência Rural 45: 379, 2015; (16) Stangarlin, O.S. et al. Summa Phytopathol. 42 (supl.): res.06. 2016.

\section{Grapevine virus D (GVD)}

The "rugose wood complex" affects grapevine's wood resulting in swelling, stem pitting below the bark. Most of the rootstock 
combination express symptoms when affected, and the disease is of economic concern in the whole world. Viruses associated to this coplex are GVA, GVB and GRSPA. Another member of the complex is GVD, detected in symptomatic grapevines, may cause reduction of growth in some rootstock varieties, being the less studied so far. Two isolates of GVD were detected and molecularly characterized in the state of Rio Grande do Sul $(1,2)$.

Ref.: (1) Dubiela, C.R. et al. In Girardi, C.L. et al. eds. Resumos, $9^{\circ}$ Encontro de IC e $5^{\circ}$ Encontro de Pós-Grad. Embrapa Uva e Vinho, Bento Gonçalves. p. 26, 2011; (2) Fajardo, T.V.M. Ciência Rural 42: 2127. 2012.

\section{Maculavirus}

\section{Grapevine fleck virus (GFkV)}

GFkV causes latent infection in commercial varieties, but induces translucent spots in the veins (vein mosaic) in the indicator 'Rupestris du Lot'. It was found in Brazilian grapevines $(1,2,7,8)$. In the state of São Paulo GFkV is present in most of the main cultivated varieties, and incidence may reach $100 \%$ (3). It has been reported to be present in grapevines cultivated in the states of Goias, Minas Gerais, Paraná and Santa Catarina (4), Rio Grande Sul (6), "submédio São Francisco" (9), Paraíba and Bahia (13), "Zona da Mata" and São Francisco valley, Minas Gerais (14), Mato Grosso do Sul (15). GFkV identity was confirmed by serological $(10)$ and molecular $(11,12)$ techniques . It was detected in cvs. 'Kyoho' and 'Olimpina', imported from Japan (5).

Ref.: (1) Kuniyuki, H. Rev.Soc.Bras.Fitopatol. 5: 189. 1972; (2) Kuniyuki, H. Fitopatologia (Lima) 11: 17. 1976; (3) Kuniyuki, H. \& Costa, A. S. Summa Phytopathol. 5: 24. 1979; (4) Kuniyuki, H. Fitopatol.bras. 6: 300. 1981; (5) Kuniyuki, H. \& Suzukawa, Y. Fitopatol.bras. 6: 533. 1981; (6) Kuhn, G.B. Fitopatol.bras. 17: 435. 1992; (7) Kuniyuki, H. \& Costa, A.S. Summa Phytopathol. 20:152. 1994; (8) Kuniyuki, H. et al. Fitopatol. bras. 20:618. 1995; (9) Kuhn, G.B. et al. Fitopatol.bras. 25: 442. 2000; (10) Kuniyuki, H. et al. Fitopatol.bras. 27: 635. 2002; (11) Fajardo, T.V.M. et al. Fitopatol. Bras. 29: 460. 2004; (12) Fajardo, T.V.M. et al. Ciência Rural 42: 2127. 2012; (13) Catarino,A.D.M. et al. Trop.Plt.Pathol. 38 (supl) CDRom 371-1.2013; (14) Catarino, A.D.M. et al. Ciência Rural 45: 379, 2015; (15) Stangarlin, O.S. et al. Summa Phytopathol. 42 (supl.): res.06. 2016 .

Marafivirus, unclassified

\section{Grapevine rupestris vein feathering virus (GRVFV)}

GRVFV was detected and identified by RT-qPCR in $8 \%$ of the collected samples from the state of Pernambuco (1). This virus is also present in the states of Bahia and Paraíba (2), and in the "Zona da Mata" and São Francisco valley in the state of Minas Gerais (3).

Ref.: (1) Catarino, A.M. et al. Trop.Plt.Pathol. 38 (supl.): CDRom 371-2. 2013; (2) Catarino,A.D.M. et al. Trop.Plt.Pathol. 38 (supl): CDRom 371-1.2013; (3) Catarino, A.D.M. et al. Ciência Rural 45: 379, 2015.

\section{Grapevine Syrah virus 1 (GSyV-1)}

Surveys made on in São Roque, SP, GSyV-1 was found infecting grapevines. Detection was made by molecular assays (1).

Ref.: (1) Moura, CJM et al. Scientia Agricola 75: 43. 2018.

Ampelovirus

Grapevine leafroll-associated virus $-1,-3,-4,-5,-6$

(GLRaV-1,-3,-4,-5,-6)

Closterovirus

\section{Grapevine leafroll-associated virus 2 (GLRaV-2)}

Grapevine leafroll, also known as reddening or yellows in the state of São Paulo, is considered one of the most important grapevine viral disease. Symptoms become visible in midsummer. Leaf rolling appears initially in basal leaves and proceeds until the end of fall, when most of leaves are rolled, reddish (still with green veins) or yellowish, rough and brittle. The disease is graft transmissible. First reported in the state of São Paulo (1), the disease is present in the states of Rio Grande do Sul (2), Goias, Minas Gerais, Paraná and Santa Catarina (3) and "submédio São Francisco", PE (7). Grapevine leafroll is caused by a complex of distinct viruses as the closterovirus GLRaV-2, and the ampeloviruses subgroup 1 (GLRaV-1,-3), subgroup II (GLRaV-4,-5,-6,-9,-Car, -Pr), velarivirus (GLRaV-7). In Brazil, the following members of the complex have been found: GLRaV -1,-2,$3(8,9,11,14,15)$, GLRaV-4 (17), GLRaV-5, -6 (10, 16). Possible elongated, closterovirus-like particles were detected in callus tissue of grapevine (4). Vitis labrusca varieties and American hybrids produces little or no symptoms, but European grapevines (Vitis vinifera) usually show severe symptoms (5). GLRaV $-1,-3,-4,-5,-6,-9$ are mealybugtransmitted. Mechanical transmission is only reported to Nicotiana spp. by GLRaV-2 (10). Indexation is made by grafting onto indicator plants, and more recently by serological or molecular assays $(11,13$, 16). GLRaV-1, -3 were found in "submédio São Francisco", PE (6), GLRaV-5 in the state of São Paulo (12), GLRaV-4 in Pernambuo (18), GLRaV -3,-4 in the states of Paraíba and Bahia (19), GLRaV-2,-3,-4 in "Zona da Mata" and São Francisco valley, Minas Gerais (2), GLRaV-3, in Mato Grosso (21).

Ref.: (1) Kuniyuki, H. Rev.Soc.Bras.Fitopatol. 5:165. 1972; (2) Kuhn, G.B. \& Siqueira, O. Fitopatologia 9:56. 1974; (3) Kuniyuki, H. Fitopatol.bras. 6: 300. 1981; (4) Vega, J. et al. Fitopatol.bras. 14: 137. 1989; (5) Kuhn, G.B. \& Nickel, O. Informe Agropecuário 19 (194): 85. 1998; (6) Kuhn, G.B. et al. Fitopatol.bras. 25: 442. 2000; (7) Lima, M.F. In Lima, M.F. \& Moreira, W.A. eds. Uva de mesa. Fitossanidade. Embrapa Inf.Tecnol. p.35. 2002; (8) Fajardo, T.V.M. et al. Fitopatol. bras. 27: 58. 2002; (9) Kuniyuki, H. et al. Summa Phytopathol. 28: 311. 2002; (10) Fajardo, T.V.M. et al. In Fajardo, T.V.M. ed. Uva para processamento-Fitossanidade. Embrapa Inf. Tecnol. p.45. 2003; (11) Fajardo, T.V.M. et al. Fitopatol.bras. 32: 335. 2007; (12) Kuniyuki, H et al. Summa Phytopathol. 34:366. 2008; (13) Radaelli, P. et al. Pesq. Agrop.Bras. 43:1405. 2008; (14) Radaelli, P. et al. Trop.Plt.Pathol. 34: 297. 2009; (15) Fajardo, T.V.M. et al. Ciência Rural 41:5. 2011; (16) Fajardo, T.V.M. et al. Ciência Rural 42:2127. 2012; (17) Catarino, A.D.M. et al. In Girardi, C.L. et al. eds. Resumos, $10^{\circ}$ Encontro IC e $6^{\circ}$ Encontro de Pós-Grad. Embrapa Uva e Vinho. p. 47, 2012; (18) Catarino, A.D.M. et al. Trop.Plt.Pathol. 38 (supl.): 371. 2013.; (19) Catarino, A.D.M. et al. Trop.Plt.Pathol. 38 (supl.): CDRom 3711.2013; (20) Catarino, A.D.M. et al. Ciência Rural 45: 379, 2015; (21) Stangarlin, O.S. et al. Summa Phytopathol. 42 (supl.): res.06. 2016.

Enamovirus

\section{Grapevine enamovirus-1}

A molecular survey of grapevine viruses was carried out in experimental fields of Embrapa Uva e Vinho, Bento Gonçalves, RS. From plants cv. 'Cabernet Sauvignon', showing severe leafroll and reddening, a virus was detected with $50 \%$ identity with Pea enation mosaic virus 1 (PEMV-1). This virus was graft transmissible. Subsequent tests detected the same virus in at least three other varieties, and it is tentatively name Grapevine enamovirus-1 $(1,2,3)$. Ref.: (1) Silva, J.M.F. et al. Virus Rev.\& Res. 20 (2): 27. 201; (2), Virus Genes 53: 667. 2017; (3) Silva, J.M.F. Diss.MS, UnB. 2018. Apscaviroid

\section{Grapevine yellow speckle viroid 1 (GYSVd-1)}

Yellow spots or specks were observed on leaves of grapevine cv. 'Niagara rosada' and 'Semillon' grown in an experimental field of Embrapa Uva e Vinho, B.Gonçalves, RS. Molecular assays detected the viroid GYSVd in these plants $(1,2)$. This viroid was also found in grapevines cultivated in the state of Mato Grosso do Sul (3).

Ref.: (1) Fajardo, T.V.M. et al. Anais do XIII Congresso Brasileiro de Viticultura e Enologia e XV Congresso Latino-Americano de Viticultura e Enologia. Bento Gonçalves: Associação Brasileira de 
Enologia e Embrapa Uva e Vinho, 2015. v. 1. p. 287; (2) Fajardo, T.V.M. et al. Trop.Plt.Pathol.41: 246. 2016; (3) Stangarlin, O.S. et al. Summa Phytopathol. 42 (supl.): res.06. 2016.

\section{Pospiviroid}

\section{Citrus exocortis viroid (CEVd)}

\section{Hop stunt viroid (HSVd)}

The Citrus exocortis viroid (CEVd - Pospiviroid) and Hop stunt viroid (HSVd - Hostuviroid) were detected in grapevines in Bento Gonçalves, RS (1-3). In surveys made in grapevine fields in the states of Rio Grande do Sul, São Paulo and Pernambuco, HSVd was found both in cultivated and wild species of Vitis ( $V$. flexuosa e $V$. tillifoliaRS, V. gigas- SP ). Detection was made by molecular assays (4).

Ref.: (1) Ferreira, A.P.M. et al. Fitopatol.bras. 17:154. 1992; (2) Fonseca, M.E.N. \& Kuhn, G. Fitopatol.bras. 19:285. 1994; (3) Eiras, M. et al. Fitopatol.bras. 31: 440. 2006; (4) Fajardo, T.V.M. et al. Australasian Plt.Dis.Notes 13: 3. 2018.

Reoviridae, unclassified

\section{Grapevine Cabernet sauvignon virus (GCSV)}

A severe leafroll was observed in cv. Cabernet Sauvignon in an experimental field of Embrapa Uva e Vinho, Bento Gonçalves, RS. Molecular assays detected a reovirus yet to be characterized, tentatively named GCSV (1).

Ref.: (1) Fajardo T.V.M. et al. Virus Rev \& Res.20 (supl.): 188. 2015. Nanovirus

Unclassified ssDNA

Temperate fruit decay associated virus (TFDaV)

A still unclassified ssDNA virus, named Temperate fruit decay associated virus (TFDaV), was found associated with reddish, coriaceous and rolled up leaves in Embrapa Uva e Vinho, Bento Gonçalves, RS, though molecular analysis. Transmission was achieved by infectious clones (1).

Ref.: (1) Basso, M.F. et al. Virus Research 210: 27. 2015.

Uncharacterized virus

\section{Grapevine LN33 stem grooving virus}

This virus was found in grapevine cultivars from "Serra Gaúcha", as part of the rugose wood complex. When graft transmitted to the indicator host 'LN33', this virus induce stem pitting (1).

Ref.: (1) Kuhn, G.B. et al. Fitopatol.bras. 27(supl.): S207. 2002.

Obs.: "Grapevine rugose wood complex" seems to be caused by coinfection of at least four viruses, which results in wood alteration of infected plants, impairing the genesis of xylem and phloem vessels. These viruses are: "Corky bark", "Rupestris stem pitting,,'Kober stem grooving", "LN33 stem grooving". These viruses can be separated using proper indicator plants, specific for each virus.

\section{Grapevine vein necrosis virus}

Vein necrosis on the grapevine rootstock cv. 'R110' was observed in the state of Rio Grande do Sul $(1,2)$. The problem is graft transmissible and infected scions show chlorotic leaves. This condition is similar to "grapevine vein necrosis" reported in other grapevine growing countries (5), and it was also noticed in the rootstock cv. 'Solferino' and some others imported from USA and Europe. It seems to be quite widespread, without causing obvious symptoms (2). Vein necrosis was also observed in the state of São Paulo (3) and in the Submédio São Francisco, Pernambuco and Paraíba (4). Causal agent is not well characterized yet, but there are reports association vein necrosis with a specific isolate of Grapevine rupestris stem pitting-associated virus $(\mathrm{GRSPaV})$.

Ref.: (1) Kuhn, G.B. Fitopatol.bras. 17: 154. 1992; (2) Kuhn, G.B. et al. Fitopatol.bras. 19:79. 1994; (3) Kuniyuki, H. et al. Fitopatol.bras. 22: 186.1997; (4) Kuhn, G.B. et al. Fitopatol.bras. 25:442. 2000; (5) Fajardo, T.V.M. et al. In Fajardo, T.V.M. ed. Uva para processamentoFitossanidade. Embrapa Inf. Tecnol. p.45. 2003.
W

*Waltheria indica L (= W. americana L) (Sleepy morning) Sterculiaceae

Begomovirus

Infectious chlorosis of malvaceae complex (ICMC)

Sleepy morning plants were found with mosaic symptoms in the state of São Paulo. Viral etiology was suggested, being the causal agent considered a member of ICMC (1).

Ref.: (1) Silberschmidt, K. \& Tommasi, L.R. Ann.Acad.Bras.Cien. 27: 195. 1955.

Begomovirus unidentified

A begomovirus, yet to be identified, was found infecting sleepy morning with mosaic symptoms in the state of Alagoas (1).

Ref: (1) Assunção, L.P. et al. Planta Daninha 24: 239.2006.

\section{*Wissadula sp. Malvaceae \\ Begomovirus}

Infectious chlorosis of malvaceae complex (ICMC)

A whitefly transmitted virus was found in Wissadula sp. with mosaic symptoms, from Alagoinha, PB and Brotas, BA. Causal agent was considered as a member of ICMC (1).

Ref.: (1) Silberschmidt, K. \& Tommasi, L.R. Ann.Acad.Bras.Cien. 27: 195. 1955.

$\mathbf{X}$

\section{*Xanthosoma atrovirens Koch \& Bouche (Malanga) Araceae Potyvirus}

Dasheen mosaic virus (DsMV)

DsMV was found infecting $X$. atrovirens causing mosaic symptoms in Brasília, DF (1).

Ref.: (1) Rodrigues, M.G.R. et al. Fitopatol. bras. 9: 291. 1984.

\section{$\mathbf{Y}$}

\section{*Yucca elephantipes Regel ex.Trel (Spineless yucca) Agavaceae Badnavirus \\ Badnavirus unidentified}

Chlorotic spots and rings were noticed in spineless yucca in the state of São Paulo. A still unidentified badnavirus was found in tissues of the infected plant, by electron microscopy (1).

Ref.: (1) Rivas, E.B. et al. Fitopatol.bras. 19: 479. 1994.

$\mathbf{Z}$

\section{*Zamioculcas zamiifolia (Lodd.) Engl. (ZZ plant) Araceae} Potyvirus

Konjac mosaic virus (KoMV)

A ZZ plant acquired from a florist in São Paulo, SP, presented mosaic and deformation on the leaves. A potyvirus was found associated with symptoms, which was identified as KoMV by RT-PCR and sequence analysis of the amplicon (1).

Ref.: (1) Alexandre, M.A.V. et al. Plant Dis. 97: 1517. 2013.

\section{*Zantedeschia aethiopica (L.) Spreng (Cara lily) Araceae Potyvirus \\ Dasheen mosaic virus (DsMV)}

DsMV was detected in Cara lily plants showing diffuse chlorotic spots on their leaves, using serology and electron microscopy (1). Ref.: 1) Galleti, S.R. et al. Res. VI Enc. Nac. Virol. p.137. 1992.

*Zanthosylum rhoifolium Lam. (Prickly ash) Rutaceae 
Potyvirus

\section{Potato virus Y (PVY)}

Serological detection of PVY was made in seedlings of $Z$. rhoifolium in a nursery of the Universidade de Brasília, Brasília, DF (1). Ref.: (1) Batista, J.G. et al. Trop.Plt.Pathol. 40 (supl): 354.2. 2015.

\section{*Zea mays L. (Maize) Poaceae}

Cytorhabdovirus

\section{Maize chlorotic vein banding virus (MCVBV)}

A disease characterized by broad chlorotic bands along the veins was found to be caused by a cytorhabdovirus in the state of São Paulo. If infection is early, plants remain stunted, and yield is seriously affected. It is transmitted in a persistent manner by the hopper Peregrinus maidis Ashm. (1) The virus was named MCVBV and has been purified (2). Virus particles were visualized both in infected plants and viruliferous vector (3). MCVBD was also found in Distrito Federal and in the states of Amazonas (4), Rio de Janeiro (5), Rio Grande do Norte (6) and Piauí (7). It may be related to the Maize yellow striate virus (MYSV) described in Argentina (8).

Ref.: (1) Costa, A.S. et al. Rev.Soc.Bras.Fitopatol. 4: 39. 1971; (2) Kitajima, E.W. et al. Fitopatol.bras. 1: 34. 1976; (3) Kitajima, E.W. \& Costa, A.S. Fitopatol.bras. 7: 247. 1982; (4) Kitajima, E.W. \& van der Pahlen, A. Fitopatol.bras. 2: 83. 1977; (5) Kitajima, E.W. et al. Fitopatol.bras. 9: 607. 1984; (6) Oliveira, F.C. et al. Fitopatol.bras. 17: 339. 1992; Beserra Jr., JEA et al. Trop.Plant Pathol. 36 (supl) CDRom. 2011; (8) Maurino, F. et al. Arch.Virol. 163: 291. 2018.

\section{Marafivirus}

\section{Maize rayado fino virus (MRFV)}

Symptoms of small linear necrotic lesions along the veins is quite common in maize crops in Brazil, referred to as "risca" by local growers. It has been proved to be caused by a marafivirus, MRFV, previously described in Central America. In Brazil apparently is not related to yield losses in single infections, but may affect productivity if present in mixed infections with other pathogens as phytoplasma, spiroplasma and potyviruses, being part of the syndrome known as corn stunt $(1,2,8,9)$. It is transmitted by the hopper Dalbulus maidis, but not mechanically (1). MRFV infect parenchymal and vascular tissues of maize. Particles are isometric, ca. $30 \mathrm{~nm}$ in diameter and could be purified (3). Virions were detected in tissues of the viruliferous vector (5). Besides state of São Paulo, where it was first reported (1), MRFV has also been reported in the states of Ceará (4), Rio de Janeiro (6), Paraná (7), Minas Gerais (8).

Ref.: (1) Costa, A.S. et al. Rev.Soc.Bras.Fitopatol. 4: 39. 1971; (2) Kitajima, E.W. et al. Proc.Amer.Phytopathol.Soc. v.2, C-15. 1975; (3) Kitajima, E.W. et al. Ciencia e Cultura 28: 427. 1976: (4) Lima, J.A.A. \& Gamez, R. Fitopatol.bras. 7: 535. 1982; (5) Kitajima, E.W. \& Gamez, R. Intervirology 19: 129. 1983; (6) Kitajima, E.W. et al. Fitopatol.bras. 9: 607. 1984; ; (7) Kitajima, E.W. \& Nazareno, N.R.X. Fitopatol.bras. 10: 613. 1985; (8) Melo, P.R. et al. Fitopatol.bras. 25: 444. 2000. (9) Gonçalves, M.C. et al. Summa Phytopathol. 33: 22. 2007.

\section{Cucumovirus}

\section{Cucumber mosaic virus (CMV)}

Chlorotic streaks and mosaic on leaves, associated to stunting were observed in maize in the state of São Paulo. This disease is of rare occurrence. Causal agent was identified as an isolate of CMV (1).

Ref.: Costa, A.S. \& Kitajima, E.W. Rev. Soc.Bras.Fitopatol. 5: 159, 1972.

\section{Polerovirus}

\section{Maize yellow mosaic virus (MaYMV)}

Yellow mosaic and stunting symptoms were noticed in commercial fields of maize in Casa Branca, SP. Molecular analysis identified the causal virus as an isolate of MaYMV with $>90 \%$ identity in the sequences (1)

Ref.: (1) Gonçalves, M.C. et al. Plant Dis. 101: 2156. 2017

Potyvirus

\section{Johnson grass mosaic virus (JGMV)}

Serodiagnosis suggested infection of maize, grown in Ribeirão Preto, SP, by an isolate of JGMV (1).

Ref.: (1) Chaves, A.L.R. et al. Fitopatol.bras. 25: 514. 2001.

Maize dwarf mosaic virus (MDMV)

Sugar cane mosaic virus (SCMV)

Infection of maize by potyvirus is common in Brazil. Possible cases of presence of potyviruses in maize were made in the state of Rio Grande do Sul in the 1960's $(1,2)$. SCMV was identified in maize in the state of São Paulo, by biological assays, including aphid transmission (3). MDMV was considered present in Brazil (4) and reported in the state of Paraná (5). Recent surveys made on maize in the states of São Paulo, Paraná, Minas Gerais and Goias, have shown that only SCMV was recovered (M.C. Gonçalves, pers.comm.). The expansion of maize culture, once a year before the 1970's, to 2-3x a year ("safrinha"), and the growth in the planted area of sugar cane, seem to have favored the increase in the incidence of SCMV and the appearance of new isolates, as being observed after the 2000's (6). Some of these isolates seems to be peculiar to Brazil (7).

Ref.: (1) Caetano,V.R. \& Siqueira, O. Rev.Soc.Bras.Fitopatol. 3: 82. 1969; (2) Hagedorn, D.J. et al. Plant Dis.Reptr. 53: 165. 1969; (3) Costa, A.S. et al. Rev. Soc. Bras. Fitopatol. 4: 39. 1971; (4) Kitajima, E.W. \& Costa, A.S. Proc.2nd Int.Colloq.Workshop Maize Virus and Mycopl. p.100. 1983; (5) Kitajima, E.W. \& Nazareno, N.R.X. Fitopatol.bras. 10: 613. 1985; (6) Gonçalves, M.C. et al. Summa Phytopathol. 33: 22. 2007; (7) Gonçalves,M.C. et al. Pesq.Agrop. Bras. 46: 362. 2011

Fijivirus

\section{Mal de Rio Cuarto virus (MRCV)}

Mal de Rio Cuarto is a serious viral disease occurring mainly in Cordoba, Argentina, characterized by leaf enation along veins in the adaxial face of leaves, stunting and anomalies in ears. Despite land continuity between this region and Brazil, the disease was considered absent in Brazil. The first and only report occurred in maize planted in Cascavel and Foz do Iguaçú, PR in 1986, based on symptoms and detection of reovirus-like particles by electron microscopy (1). No further cases have been registered so far.

Ref.: (1) Trevisan, W.L. et al. Fitopatol.bras. 11: 265. 1986.

\section{*Zeyheria tuberculosa (Vell.) Bureau ex. Verl. Bignoniaceae Cucumovirus}

Cucumber mosaic virus (CMV)

Potyvirus

Papaya ringspot virus (PRSV)

Potato virus Y (PVY)

CMV, PVY e PRSV were detected by serology in seedlings of $Z$. tuberculosa in a nursery of the Universidade de Brasíllia, DF (1). Ref.: (1) Batista, J.G. et al. Trop.Plt.Pathol. 40 (supl): 354.2. 2015.

\section{*Zingiber officinale Roscoe (Ginger) Zingiberaceae Cucumovirus \\ Cucumber mosaic virus (CMV)}

Ginger plants with stunting, small rhizomes, and general chlorosis were found in the state of São Paulo, SP. Following biological and serological assays and electron microscopy identified the causal agent of the disorder as an isolate of CMV (1).

Ref.: (1) Colariccio, A. et al. Res. VI Enc. Nac. Virol. p. 182. 1992.

\section{*Zinnia elegans JACQ. (Zinnia) Asteraceae \\ Potyvirus}




\section{Bidens mosaic virus (BiMV)}

Zinnia plants showing mosaic symptoms were found in a residential garden in Brasília, DF. The causal agent of the symptoms was identified as an isolate of BiMV (1).

Ref.: (1) Kitajima, E.W. \& Lima, M.I. Fitopatol.bras. 16: XXVI. 1991.

\section{Sunflower chlorotic mottle virus (SuCMoV)}

Potyvirus causing mosaic symptoms in Zinnia was registered in the Northwest of the state of São Paulo. Biological and molecular assays identified this virus as an isolate of $\mathrm{SuCMoV}$, originally described in Argentina (1).

Ref.: (1) Maritan, A.C. et al. Fitopatol. bras. 29: 28. 2004.

Tobamovirus

\section{Tobacco mosaic virus (TMV)}

In São José do Rio Preto, SP, zinnia plants were found with mosaic symptoms. Further assays indicated that they were co-infected by a potyvirus, possibly BiMV, and an isolate of TMV

Ref.: (1). Maritan, C. \& Gaspar, J.O. Fitopatol.bras. 26: 533. 2001.

\section{Conclusions}

This annotated list reports plant viruses described naturally infecting plants, cultivated or from spontaneous vegetation, in the Brazilian territory from the early reports in the 1920 ' to 2018. Most of them were possibly introduced, but there are several autochthonous viruses. The large majority cause marginal diseases which result in minor but consistent losses. Few of them, however, caused and may cause major outbreaks with severe yield losses, due to favorable epidemiological conditions and lack of natural resistance in host plants.

\section{Author Contributions}

Elliot W. Kitajima: Substantial contribution in the concept and design of the study; Contribution to data collection; Contribution to data analysis and interpretation; Contribution to manuscript preparation; Contribution to critical revision, adding intelectual content.

\section{Conflicts of interest}

The authors declare that they have no conflict of interest related to the publication of this manuscript.

\section{References}

ALBOUY, J. \& DEVERGNE, J-C. (2000) Enfermedades producidas por virus de las plantas ornamentals. Ed.Mundi-Prensa, Madri.

ANDERSON, P.K. \& MORALES, F.J. (eds.) 2005. Whitefly and whiteflyborne viruses in the Tropics: Building a knowledge base for global action. CIAT, Cali.

BRUNT, A., CRABTREE, K. \& GIBBS, A. 1990. Viruses of Tropical Plants. $\mathrm{CAB}$ International, Wallingford.

COSTA, A.S. 1986. História da fitovirologia no Brasil. Anais da Esc.Sup.Agric. Luiz de Queiroz 43- 51-78.

FERNÁNDEZ-VALIELA, M.V 1995. Virus patógenos de plants y su control. Vol. $1 \& 2$. $4^{\text {th }}$ ed. Acad.Nac.Agronomia y Veterinaria, Buenos Aires.

FORTERRE, P. 2006. The origins of viruses and their possible roles in major evolutionary transitions. Virus Res. 1177: 5-16.

GARCIA-ARENAL, F., FRAILE, A. \& MALPICA, J.M. 2003. Variation and evolution of plant virus populations. Int.Microb. 6:225-232.
HULL, R. Plant Virology, 5th ed. 2014. Elsevier, Amsterdam.

ICTV Master Species List 2018 v.2. 2019. https:talk.ictvonline.org/files/masterspecies-lists $/ \mathrm{m} / \mathrm{msl} / 8266$

KITAJIMA, E.W. 1986. Lista de publicações sobre viroses e enfermidades correlatas de plantas no Brasil (1911-1985). Soc.Bras.Fitopatol., Brasília.

KITAJIMA E.W. 1995. Lista de publicações sobre viroses e enfermidades correlatas de plantas no Brasil (1986-1993). Soc.Bras.Fitopatol., Brasília.

KOONIN, E.V. \& DOLJA, V. 2006. Evolution of complexity in the viral world: the dawn of a new vision.Virus Res. 117: 1-4. doi:10.1016/j. virusRes.2006.01.018

KRUPOVIC, M., DOLJA, V.V. \& KOONIN, E.V. 2019. Origin of viruses: primordial replicators recruiting capsids from hosts. Nature Rev.Microbiol 17: 449-458. doi: 10.1038/s41579-019-0205-6

LEFEUVRE, , P., MARTIN, D.P., ELENA, S.F., SHEPHERD, D.N., ROUMAGNAC, P. \& VARSANI, A. 2019.Evolution and ecology of plant viruses. Nature Reviews/Microbiology.

LAPIERRE, H. \& SIGNORET, P.-A, eds. 2004.Viruses and virus diseases of Poaceae (Gramineae). INRA, Paris.

MARCHOUX, G., GOGNALONS, P. \& SÉLASSIEÉ, K.G. (coord.) 2008. Virus des Solanacées. Du genome viral à la protection des cultures. Ed.Quae, Versailles.

MURAYMA, D., AGRAWAL, H.O., INOUE, T., KIMURA, I., SHIKATA, E., TOMARU, K., TSUCHIZAKI, T. \& TRIHARSO, I. (eds.) 1998. Plant viruses in Asia. Gadjah Mada Univ.Press, Blaksumur.

REZENDE, J.A.M. \& KITAJIMA, E.W. 2018. Virus e viroides. In Manual de Fitopatologia vol.1. Princípios e Conceitos. $5^{\text {a }}$ Ed. (AMORIM, L., BERGAMIN Fo., A. \& REZENDE, J.A.M. Eds.). Agronomica Ceres, Ouro Fino. p.161-180.

REUTER, J.A., SPACEK, D \& SNYDER, M.P. 2015. High-throughput sequencing Technologies. Mol.Cell 58(4): 586-597.

SHORS, T. 2008.Understanding viruses. Jones \& Bartlett Publ., Sudbury.

SILBERSCHMIDT, K.M. 1943. Estudos sobre a transmissão experimental da clorose infecciosa das malváceas. Arq.Inst.Biol.14: 105-156.

SIMMONDS, P. 2009. Virus evolution. Microbiology Today 36 (2): 96-99.

VAN REGENMORTEL, M.H.V. 2016. Only viruses, but not their genome sequences, can be classified into hierarchical species and genus classes. Current Topics in Virology 13: 59-68.

WALKER, P.J., SIDDELL, S.G., LEFKOWITZ, E.J. MUSHEGIAN, A.R., DEMPSEY, D.M., DUTILH, B.E, HARRACH, B., HARRISON, L., HENDRICKSON, R.C., JUNGLEN, S., KNOWLES, N.J., KROPINSKI, A.M., KRUPOVIC, M., KUHN, J.H., NIBERT, M., RUBINO, L., SABANADZOVIC, S., SIMMONDS, P., VARSANI, A., ZERBINI, F.M., DAVISON, A.J. Changes to virus taxonomy and the International Code of Virus Classification and Nomenclature ratified by the International Committee on Taxonomy of Viruses. 2019. Arch.Virology 164: 2417-2429.

Received: 04/12/2019

Revised: $20 / 01 / 2020$

Accepted: 30/01/2020

Published online: 08/05/2020 